\title{
O ENSINO DE CIÊNCIAS
}

no Brasil durante e após a pandemia da Covid-19

\section{perspectivas, desafios e possibilidades}

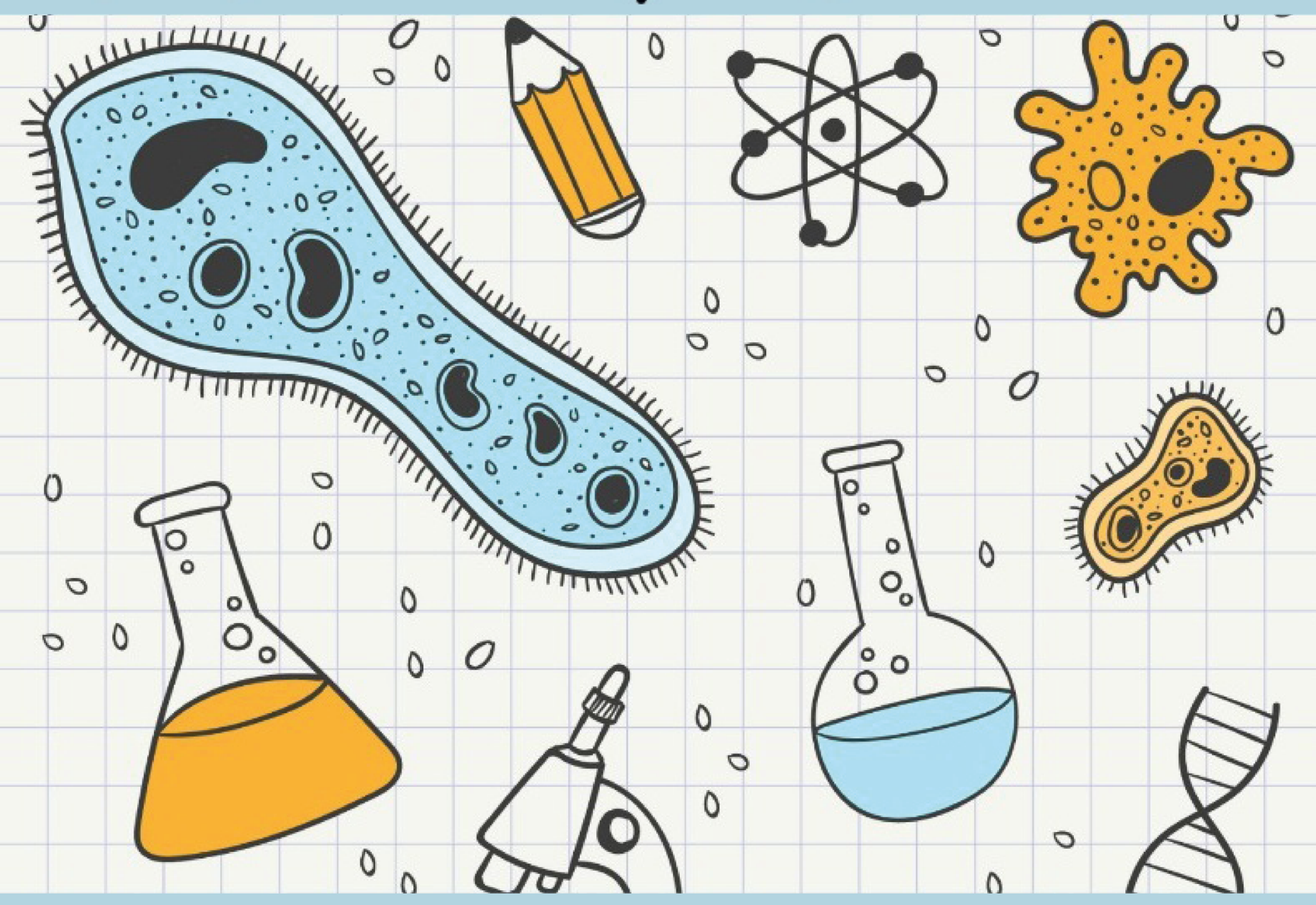

Alberto Lopo Montalvão Neto

Flávia Novaes Moraes Wanderson Rodrigues Morais

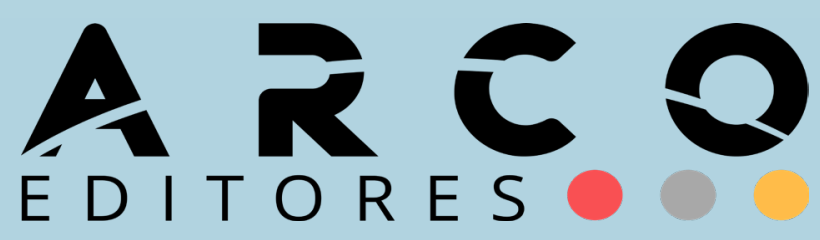




\section{O ENSINO DE CIÊNCIAS}

no Brasil durante e após a pandemia da Covid-19

\section{perspectivas, desafios e possibilidades}

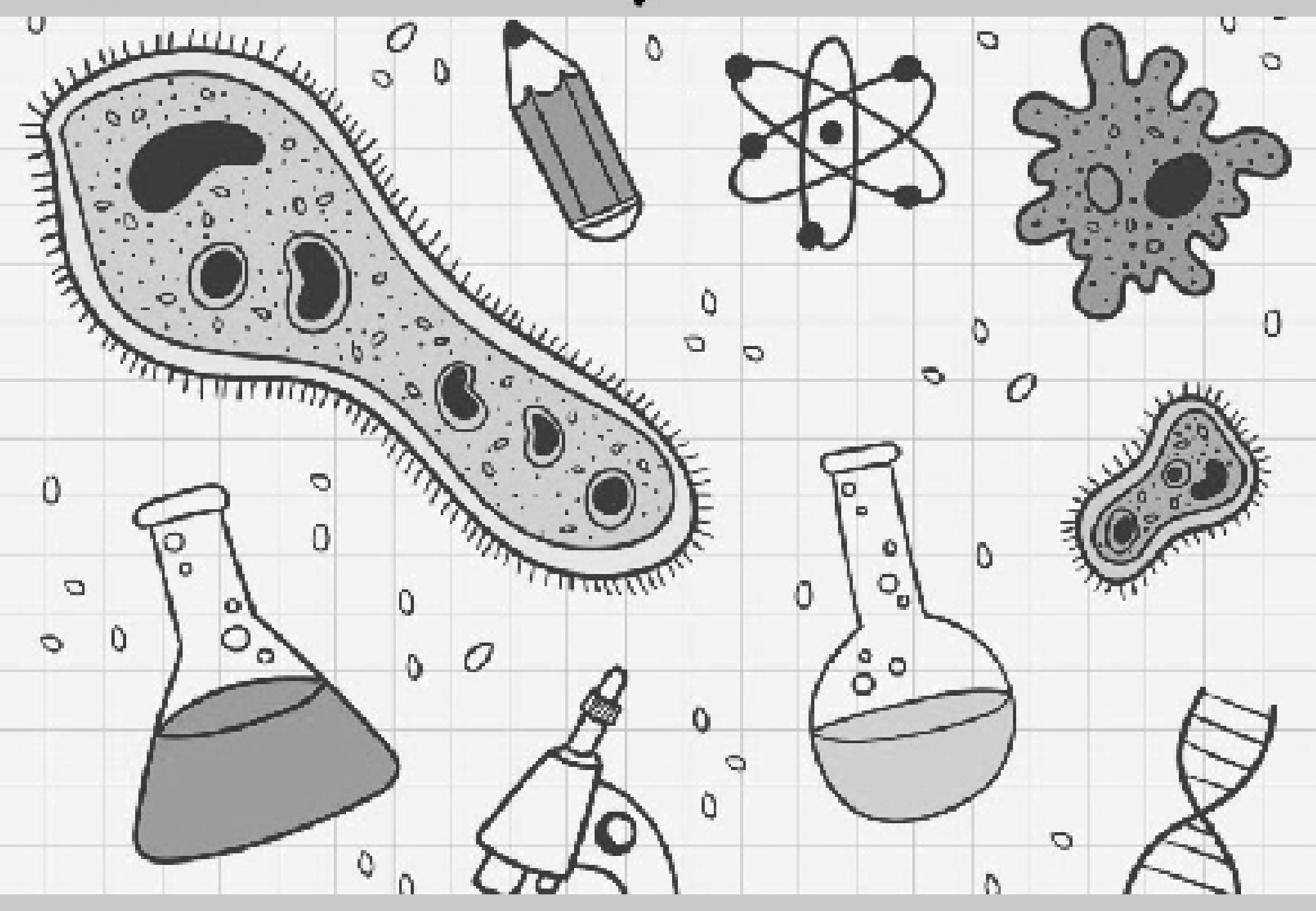

Alberto Lopo Montalvão Neto

Flávia Novaes Moraes Wanderson Rodrigues Morais

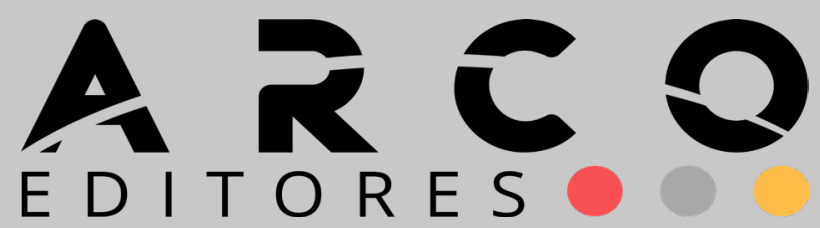




\section{Conselho Editorial}

Prof. Dr. Adilson Tadeu Basquerot e Silva

Profa. Msc. Jesica Wendy Beltrán

Profa. Dra Fabiane dos Santos Ramos

Dr. João Riél Manuel Nunes Vieira de Oliveira Brito

Profa. Dra. Alessandra Regina Müller Germani

Prof. Dr. Everton Bandeira Martins

Prof. Dr. Erick Kader Callegaro Corrêa

Prof. Dr. Pedro Henrique Witchs

Prof. Dr.Thiago Ribeiro Rafagnin

Prof. Dr. Mateus Henrique Köhler

Profa. Dra. Liziany Müller Medeiros

Prof. Dr. Camilo Darsie de Souza

Prof. Dr. Dioni Paulo Pastorio

Prof. Dr. Leonardo Bigolin Jantsch

Prof. Dr. Leandro Antônio dos Santos

Dr. Rafael Nogueira Furtado

Profa. Dra. Angelita Zimmermann

Profa. Dra. Francielle Benini Agne Tybusch

Dados Internacionais de Catalogação na Publicação (CIP)

(Câmara Brasileira do Livro, SP, Brasil)

\begin{tabular}{l} 
0 ensino de ciências no Brasil durante e após a \\
pandemia da Covid-19: perspectivas, desafios e \\
possibilidades [livro eletrônico] / organização \\
Alberto Lopo Montalvão Neto, Flávia Novaes Moraes , \\
Wanderson Rodrigues Morais. -- Santa Maria, RS : \\
Arco Editores, 2021. \\
PDF ISBN 978-65-89949-13-8 \\
1. Ensino de Ciências 2. Educação em Ciências 3. \\
MoRAES, Flávia Novaes . III. M0RAIS, Wanderson \\
21-77592 II. \\
\hline
\end{tabular}

Índices para catálogo sistemático:

1. Ciências : Estudo e ensino 507

Aline Graziele Benitez - Bibliotecária - CRB-1/3129 


\section{EPÍGRAFE}

"É preciso ter esperança, mas ter esperança do verbo esperançar; porque tem gente que tem esperança do verbo esperar. $E$ esperança do verbo esperar não é esperança, é espera. Esperançar é se levantar, esperançar é ir atrás, esperançar é construir, esperançar é não desistir!" (Paulo Freire). 
Agradecemos à Coordenação de Aperfeiçoamento de Pessoal de Nível Superior (CAPES) e ao Conselho Nacional de Desenvolvimento Científico e Tecnológico (CNPq) pelas bolsas concedidas e que permitiram os nossos estudos no âmbito de mestrado e doutorado acadêmico. 


\section{APRESENTAÇÃO}

A pandemia decorrente da disseminação do novo coronavírus assola o mundo desde o início de 2020. Entre tantas controvérsias e informações veiculadas por diferentes meios de comunicação, fidedignas ou não, a Ciência continua ocupando um lugar de destaque em diversas esferas, principalmente por se pautar em evidências sustentadas e não em posicionamentos ou juízos de valor particulares. Outrossim, com as normas de restrição de convívio social impostas por instâncias legislativas do Brasil, tais como os mecanismos de distanciamento social para evitar o contágio da doença, o ensino remoto emergencial passou a ser a única alternativa para permitir a continuidade das práticas educativas nacionais.

Nesse cenário, a escassa familiaridade por parte dos estudantes com o ensino remoto emergencial (ERE) e a falta de acesso de muitos aos dispositivos eletrônicos e a internet, se apresentaram como grandes desafios à continuidade da educação e ao abandono das atividades escolares. Outra questão relevante, que se tornou latente nos últimos tempos, foi o grau de proximidade das pessoas com os conteúdos de divulgação científica relativos ao contexto pandêmico. Em outras palavras, as razões para o distanciamento de parte da população em relação aos conteúdos provenientes da produção científica, e que podem esclarecer o momento que vivenciamos e colaborar no enfrentamento à situação pandêmica, remontam ao cenário dessa crise que, não apenas é sanitária, como também social.

Considerando o contexto exposto, a presente coletânea congrega trabalhos inéditos, de diferentes naturezas teóricas, analíticas e/ou empíricas, que se voltam a reflexões a respeito da Educação em Ciências. A obra é composta por 13 estudos que versam a respeito de distintos campos disciplinares (Ciências Naturais, Biologia, Física, Geociências e Pedagogia), e que têm como foco diferentes níveis educacionais (ensino fundamental, ensino médio, graduação, pós-graduação e educação não-formal). Esses estudos abordam questões relativas ao ensino durante a pandemia do vírus da COVID-19, colocando assim os desafios, possibilidades e perspectivas das relações de ensino e de aprendizagem, no âmbito da educação científica e tecnológica, diante da crise sanitária e social que vivenciamos.

Dito isto, apresentamos brevemente os capítulos que compõem esta obra.

O primeiro capítulo, elaborado pelos organizadores, traz uma revisão bibliográfica a respeito da pesquisa em Ensino de Biologia em tempos de pandemia. Nesse sentido, objetivando compreender a produção acadêmica da área, principalmente no que toca aos 
seus objetivos, principais enfoques e conclusões, os autores traçam uma perspectiva sobre os impactos, possibilidades e perspectivas do Ensino de Biologia diante dos percalços ocasionados pela pandemia do novo coronavírus.

Num segundo capítulo os autores Marcelo Alberto Elias e Allana Carla Garcia dos Santos apresentam algumas propostas de metodologias ativas visando abrir possibilidades para o desenvolvimento de atividades de ensino de caráter investigativo. Nesse sentido, os autores debruçam-se sobre a temática "dengue" para trazer propostas de trabalho com o ensino fundamental, considerando que, em meio à pandemia da COVID-19, outras doenças continuam a ser questões socialmente relevantes e pauta de discussão.

No terceiro capítulo, Marcelo Alberto Elias e seus colaboradores apresentam uma proposta de sensibilização a respeito de complicações à saúde ocasionadas pela COVID-19 e que são pouco evidenciadas, tais como as complicações gastrointestinais. Nesse sentido, a partir de uma revisão de literatura e da consequente apresentação de uma estratégia de popularização do conhecimento científico, por meio da transposição didática de artigos científicos para textos que possuem elementos de divulgação científica, os autores colocam uma proposta educacional voltada à prevenção e promoção da saúde.

O quarto capítulo, elaborado por Lilia Cavicchioli Fonseca Iatecola e Rita de Cássia Frenedozo, aborda uma discussão sobre o uso de ambientes virtuais na educação, a partir de uma avaliação da disciplina de Anatomia Humana, realizada remotamente, em um curso de Fisioterapia. O debate proposto pelas pesquisadoras agrega contribuições da literatura e a percepção dos alunos sobre a participação na referida disciplina, evidenciando aspectos positivos e potencialidades para essa nova abordagem, e reconhecendo, ainda, algumas limitações no contexto de ensino remoto.

Em um quinto capítulo, Camilla Carvalho Gomes, Andre Santos Amorim e Karina Carvalho Mancini apresentam um recorte de uma dissertação, desenvolvida no âmbito de mestrado acadêmico, que busca debater a urgência da inclusão de smartphones no Ensino de Biologia. Além do debate sobre o uso de smartphones no ensino, os autores apresentam alguns dos principais aplicativos com potencial para contribuir com o ERE e com a educação em Biologia em contextos pós-pandêmicos.

No sexto capítulo, o autor Tiago Maretti Gonçalves traz reflexões e propostas relacionadas às potencialidades do uso da experimentação no Ensino de Ciências/Biologia em meio ao ERE. As discussões e práticas expostas pelo trabalho visam fomentar a aprendizagem de conteúdos relacionados à Fisiologia Animal e Humana, no âmbito do Ensino Médio, mais especificamente no que se relaciona à digestão de proteínas. 
O sétimo capítulo, de autoria de Érica Romão da Silva Lima e Haroldo Reis Alves de Macêdo, apresenta um breve levantamento e análise de softwares de realidade virtual para o Ensino de Física. A partir da discussão da tecnologia enquanto ferramenta para a educação e do reconhecimento das potencialidades do uso da realidade virtual, os pesquisadores colocam em destaque o papel das metodologias ativas como perspectiva de ensino à disposição do professor de física, analisando dois aplicativos em vista de seus usos e aspectos técnicos.

Para o oitavo capítulo, Thomáz da Silva Guerreiro Botelho, Maria Inês de Affonseca Jardim e Amanda de Mattos Pereira Mano trazem reflexões sobre o processo de transição do ensino presencial para o ERE e o desenrolar da disciplina de Ciências em uma escola pública do estado do Mato Grosso do Sul. Os pesquisadores avaliaram as ações e o percurso dos alunos no que diz respeito ao seu desempenho e realização das atividades ao longo do período letivo em contexto pandêmico, colocando em debate a experiência vivida e traçando contribuições para o ensino a partir de fragilidades e potencialidades deste cenário.

No nono capítulo, Luiz Antonio Soares Cardoso relata algumas experiências vivenciadas no oferecimento das disciplinas dos cursos de Tecnologia em Gestão Ambiental e Licenciatura em Geografia, abordando um pouco sobre o processo de transição do ensino presencial ao remoto, principalmente em relação às dificuldades e metodologias propostas, traçando assim algumas contribuições para outras instituições que estão enfrentando os mesmos dilemas ocasionados pelo contexto pandêmico.

No décimo capítulo, Elaine Lima Silva e seus colaboradores abordam a relação Ciência, Tecnologia e Sociedade (CTS) através do ensino de temáticas relativas às vacinas, à vacinação e ao movimento antivacina. Com o uso de atividades remotas foram desenvolvidas atividades a partir do uso de textos e filmes com alunos do primeiro e do terceiro ano do Ensino Médio de uma escola estadual técnica da zona leste de São Paulo. $\mathrm{O}$ estudo permitiu não somente o acesso dos estudantes às informações científicas como também possibilitou a formação de posicionamentos críticos perante a essas questões.

No décimo primeiro capítulo, Larissa Rodrigues Pereira, Ana Flavia Zorzi e Mayra da Silva Cutruneo Ceschini retrataram o desenvolvimento e a aplicação de uma trilha interativa virtual com a temática reciclagem, a partir de pontos já existentes na Trilha física do Campus Verde da Universidade Federal do Pampa. O trabalho em questão foi conduzido com uma turma de $4^{\circ}$ ano de uma escola da rede municipal de ensino de São 
Gabriel-RS e traz uma possibilidade de trabalho remoto utilizando elementos de uma trilha presencial da universidade.

No décimo segundo capítulo as autoras Ivana Tharini de Lima Leal e Priscyla Cristinny Santiago da Luz desenvolveram um trabalho com alunos do $7^{\circ}$ ano do Ensino Fundamental de uma escola pública no município de Abaetetuba, no estado do Pará. Para tanto, produziram vídeos com recursos pedagógicos construídos a partir do miriti (Mauritia flexuosa), abrangendo as temáticas seres humanos e suas relações com os impactos ambientais, fenômenos naturais e artificiais, biomas brasileiros, vacinação, diferenciação das partículas virais e suas influências no ser humano e a destruição da camada de ozônio. As autoras concluem que o uso do miriti promove a valorização da biodiversidade e das culturas locais associados às temáticas biológicas relevantes.

Por fim, o décimo terceiro capítulo, de autoria de Cláudia de Oliveira Lozada, apresenta uma proposta inovadora com foco no ensino de astronáutica por meio de uma trilha interativa. Essa proposta tem como possibilidade o uso da trilha interativa em contextos de ensino presencial e em situações de ensino remoto.

Congregando este rico conjunto de estudos, acreditamos que trazemos contribuições para o Ensino de Ciências em seus mais variados espaços, na medida em que, ao julgar que a Ciência é uma importante forma de ver o mundo, esses estudos, com os mais diversificados enfoques, propósitos e objetos de pesquisa, permitem olhares outros sobre o atual momento. Mais do que denúncias, esses olhares trazem anúncios e possibilidades de "esperançar".

Boa leitura!

Alberto Lopo Montalvão Neto Flávia Novaes Moraes Wanderson Rodrigues Morais (Organizadores) 


\section{SUMÁRIO}

\section{CAPÍTULO 1}

ENSINO REMOTO EMERGENCIAL: UM ESTUDO EXPLORATÓRIO SOBRE

O ENSINO DE BIOLOGIA EM TEMPOS DE PANDEMIA...............................14

Alberto Lopo Montalvão Neto

Wanderson Rodrigues Morais

Flávia Novaes Moraes

doi: 10.48209/978-65-89949-13-1

CAPÍTULO 2

LÁ VEM A DENGUE: UMA PROPOSTA DE SENSIBILIZAÇÃO A PARTIR DO USO DE METODOLOGIAS ATIVAS EM TEMPOS DE ENSINO REMOTO.....33

Allana Carla Garcia dos Santos

Marcelo Alberto Elias

Margarida Maria Sandeski

Alex Sandro Barros de Souza

Renata Rúbia Ota

doi: 10.48209/978-65-89949-13-2

CAPÍTULO 3

COMPLICAÇÕES GASTROINTESTINAIS RELACIONADAS À COVID-19:

UMA PROPOSTA DE SENSIBILIZAÇÃO POR MEIO DA DIVULGAÇÃO CIENTÍFICA.....................................................................................

Marcelo Alberto Elias

Paula Montanhini Favetta

Wesley Alves Trindade

Flavio de Souza Júnyor

Ricardo de Melo Germano

doi: 10.48209/978-65-89949-13-3 
CAPÍTULO 4

A UTILIZAÇÃO DE AMBIENTES VIRTUAIS DE APRENDIZAGEM NO ENSINO DE ANATOMIA HUMANA ........................................................57

Lilia Cavicchioli Fonseca latecola

Rita de Cássia Frenedozo

doi: 10.48209/978-65-89949-13-4

CAPÍTULO 5

SMARTPHONE NO ENSINO DE BIOLOGIA: UMA INCLUSÃO URGENTE NA EDUCAÇÃO BÁSICA.. .75

Camilla Carvalho Gomes

Andre Santos Amorim

Karina Carvalho Mancini

doi: 10.48209/978-65-89949-13-5

CAPÍTULO 6

O ENSINO DE BIOLOGIA EM TEMPOS DE PANDEMIA: UM LABORATÓRIO CASEIRO PARA A SIMULAÇÃO DA DIGESTÃO DE PROTEÍNAS. .98

Tiago Maretti Gonçalves

doi: 10.48209/978-65-89949-13-6

\section{CAPÍTULO 7}

REALIDADE VIRTUAL: UMA ALTERNATIVA TECNOLÓGICA PARA 0 ENSINO DE FÍSICA

Érica Romão da Silva Lima

Haroldo Reis Alves de Macêdo

doi: 10.48209/978-65-89949-13-7 
CAPÍTULO 8

ATIVIDADES REMOTAS NA DISCIPLINA DE CIÊNCIAS E AS POSSIBILIDADES PARA UM PERÍODO PÓS-PANDEMIA........................136

Thomáz da Silva Guerreiro Botelho

Maria Inês de Affonseca Jardim

Amanda de Mattos Pereira Mano

doi: 10.48209/978-65-89949-13-0

\section{CAPÍTULO 9}

ENSINO DAS GEOCIÊNCIAS EM TEMPOS DE PANDEMIA: RELATO DE EXPERIÊNCIA.

Luiz Antonio Soares Cardoso

doi: 10.48209/978-65-89949-13-9

CAPÍTULO 10

A ABORDAGEM CTS NO ENSINO DE BIOLOGIA: USANDO O MOVIMENTO ANTIVACINA COMO QUESTÃO NORTEADORA 164

Elaine Lima Silva

Rita de Cássia Frenedozo

Rosione Maria dos Santos Rodrigues

Tatiane Tenuta de Andrade

Vera Maria Jarcovis Fernandes

doi: 10.48209/978-65-89949-10-8

CAPÍTULO 11

INTERVENÇÃO PEDAGÓGICA EM ESPAÇO NÃO-FORMAL DE EDUCAÇÃO: TRILHA INTERPRETATIVA VIRTUAL COM TEMA RECICLAGEM...................................................................................... 180

Larissa Rodrigues Pereira

Ana Flavia Zorzi

Mayra da Silva Cutruneo Ceschini

doi: 10.48209/978-65-89949-11-8 
CAPÍTULO 12

O USO DE RECURSOS DIDÁTICOS DE MIRITI NO ENSINO DE CIÊNCIAS: POSSIBILIDADES EDUCATIVAS NA PANDEMIA DA COVID-19.............192

Ivana Thariny de Lima Leal

Priscyla Cristinny Santiago da Luz

doi: 10.48209/978-65-89949-12-8

CAPÍTULO 13

ENSINO DE CIÊNCIAS: APRESENTAÇÃO DE UMA PROPOSTA DE TRILHA DE APRENDIZAGEM PARA O ENSINO DE CONTEÚDOS DE ASTRONÁUTICA NO $5^{\circ}$ ANO DO ENSINO FUNDAMENTAL .212

Claudia de Oliveira Lozada

doi: 10.48209/978-65-89949-14-8

SOBRE OS ORGANIZADORES 
doi $10.48209 / 978-65-89949-13-1$

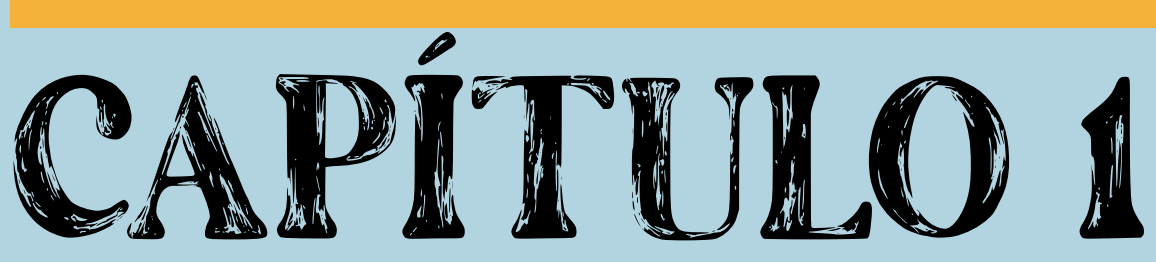

\section{ENSINO REMOTO EMERGENCIAL: UM ESTUDO EXPLORATÓRIO SOBRE O ENSINO DE BIOLOGIA EM TEMPOS DE PANDEMIA}

Alberto Lopo Montalvão Neto Wanderson Rodrigues Morais Flávia Novaes Moraes 


\section{INTRODUÇÃo}

A sociedade passa ainda hoje pelos efeitos da pandemia ocasionada pelo vírus Sars-CoV-2, causador da doença Covid-19 (WHO, 2020). Desde o último mês de 2019, com o alastramento da enfermidade, crises se instauraram em vários âmbitos: sanitário, social, político, econômico e científico, afetando todas as estruturas de poder e organizações. Atualmente, o Brasil conta com mais de 530 mil óbitos acumulados ${ }^{1}$ e mais de 4 milhões no mundo ${ }^{2}$, com vários países adotando diferentes esquemas de vacinação. Em território brasileiro, isso ocorre de forma mais atrasada ${ }^{3}$, havendo, inclusive, investigações sobre a gestão governamental como uma possível causa desse atraso, mostrando assim a negligência com a população ${ }^{4}$. Podemos dizer, então, que no âmbito brasileiro vivenciamos necropolíticas (MBEMBE, 2016) .

No início de 2020, a Portaria $n^{\circ} 188$ de 3 de fevereiro anunciou medidas de emergência a serem adotadas no país, como aquelas referentes ao distanciamento social / quarentena, forçando a paralisação ou reinvenção de atividades nas mais variadas esferas, tais como, por exemplo, a educacional. Esse cenário forçou mudanças rápidas na forma de organização do trabalho escolar, em que as unidades federativas adotaram distintos processos para lidar com a declaração governamental (BRASIL, 2020, CUNHA; SILVA; SILVA, 2020).

Nesse cenário, algumas secretarias de educação suspenderam as aulas, enquanto outras reorganizaram o calendário escolar e a carga horária letiva. De forma geral, parcerias com estações de televisão, rádio e mídias também foram feitas. Cunha, Silva e Silva (2020) apresentam um breve resumo das distintas resoluções propostas nos estados brasileiros, em que o uso ou não de Tecnologias Digitais da Informação e Comunicação (TDIC's) caracterizam, conjuntamente à

$1 \quad$ Conforme dados disponíveis em: https://covid.saude.gov.br/. Acesso em: 09 jul. 2021.

2 Conforme dados disponíveis em: https://www.worldometers.info/coronavirus/. Acesso em: 09 jul. 2021.

3 Disponível em: https://www.correiobraziliense.com.br/brasil/2021/06/4930907-brasil-vive-cenario-de-atrasos-e-avancos-na-vacinacao-contra-covid-19.html. Acesso em: 09 jul. 2021. 4 Disponível em: https://www12.senado.leg.br/noticias/materias/2021/04/13/senado-cria-cpi-da-covid. Acesso em: 09 jul. 2021.

5 Discussões mais profundas sobre as (necro)políticas relacionadas ao atual governo brasileiro em meio à pandemia da Covid-19 são realizadas em Montalvão Neto, Silva Filho e Rocha (2021a). 
situação experienciada, um novo momento da realidade nas escolas: o ensino remoto. Nesse contexto, Hodges e seus colaboradores (2020) propõem o termo "Ensino Remoto de Emergência” ou também chamada de "Ensino Remoto Emergencial" (ERE), que é caracterizado como:

[...] Uma mudança temporária para um modo de ensino alternativo devido a circunstâncias de crise. Envolve o uso de soluções de ensino totalmente remotas para o ensino que, de outra forma, seriam ministradas presencialmente ou como cursos híbridos, e, que, retornarão a esses formatos assim que a crise ou emergência diminuir ou acabar. O objetivo nessas circunstâncias não é recriar um sistema educacional robusto, mas fornecer acesso temporário a suportes e conteúdos educacionais de maneira rápida (HODGES et al., 2020, p. 6).

O ERE guarda diferenças de outros modelos de ensino que se utilizam das TDIC's, tais como o Ensino a Distância (EaD) ou o ensino online. Os cursos EaD I online contam com tempos extensos de planejamento dos conteúdos, metodologias e de processos avaliativos, exibindo um funcionamento de ambiente virtual construído a partir dos objetivos educacionais, demandando assim um período de idealização e estruturação próprios à natureza do curso. Destarte, "[...] a educação online eficaz exige um investimento em um sistema de apoio ao aluno, que leva tempo para ser identificado e construído" (CUNHA; SILVA; SILVA, 2020, p. $5)$, diferentemente das condições críticas nas quais o ERE se configura.

Nesse âmbito do ERE, reconhecemos a importância de se refletir sobre o Ensino de Ciências, considerando as influências político-sociais que exercem grande impacto na atividade científica e na imagem de Ciência que circula e chega ao grande público, seja pelos meios formais de ensino, como, por exemplo, a escola; seja pela divulgação científica e ou pelo discurso jornalístico. Fato é que muitas são as informações que circulam na sociedade a respeito das questões científicas e (bio)tecnológicas em tempos de pandemia, tais como questões relacionadas ao vírus da Covid-19 e a vacina, sendo as informações veiculadas muitas vezes difusas (MORAES; MONTALVÃO NETO; MORAIS, 2021) em meio à um contexto marcado pela disseminação de fake news, no horizonte do que tem se formado na contemporaneidade de pós-verdades ${ }^{1}$.

1 "Relativo à ou denota circunstâncias nas quais fatos objetivos têm menos influência em moldar a opinião pública do que apelos à emoção e a crenças pessoais" (OXFORD, 2021, s. p). 
Assim, a crise científica enfrentada atualmente, especificamente em território brasileiro, é apenas um sintoma de uma gama de fatores que variam em dimensão, desde o descrédito da Ciência até o sucateamento do ensino e o corte dos recursos providos para a realização de pesquisas no país ${ }^{1}$ (ALMEIDA; SILVA, 2020; MORAIS; MORAES, 2021; MONTALVÃO NETO; SILVA FILHO; ROCHA, 2021b). Destarte, consideramos que:

O desconhecimento de uma parte significativa da população acerca do que é a Ciência, associado à desinformação disseminada por determinados grupos, cria um ambiente propício ao aparecimento e proliferação de visões distorcidas e errôneas e de movimentos anti ciência (REIS, 2021, p. 1).

Diante desse contexto pandêmico, a adoção do modelo de ERE para o trabalho escolar, de forma muitas vezes precária, e mediante a crise científica que vivenciamos, o Ensino de Ciências torna-se ainda mais fundamental por ser capaz de propiciar vias de transformação social. Tal transformação se dá pela promoção de competências que asseguram uma educação científica alargada a todos os cidadãos, preocupando-se com a capacitação e o empoderamento para uma transformação de forma democrática, colaborativa e fundamentada na Ciência, tornando o sujeito capaz de tomar decisões e discutir as questões sociocientíficas de sua época ${ }^{2}$. Além disso, promove uma concepção de Ciência como atitude crítica, questionadora e de autonomia intelectual (REIS, 2021, MORAIS; MORAES, 2021).

Tendo em vista o papel do Ensino de Ciências nas condições atuais, o momento se torna propício para a compreensão de como a educação científica tem se dado nesse contexto, focando neste manuscrito mais especificamente o Ensino de Biologia, área comum de formação dos autores deste estudo. Assim, o objetivo deste trabalho é refletir sobre algumas das principais dificuldades, desa-

1 Disponível em: http://www.sintietfal.org.br/2020/08/educacao-governo-bolsonaro-anuncia-corte-de-r-42-bilhoes-no-orcamento-de-2021/. Acesso em: 09 jul. 2021.

2 Conforme apontam Sasseron e Carvalho (2011), diferentes terminologias são utilizadas quanto à questão, tais como, por exemplo, "alfabetização científica", "letramento científico" e "enculturação científica". Fato é que, ao vermos a Ciência sob uma perspectiva cultural, cabe ao ensino de Ciências criar condições para que os estudantes possam inserir-se nessa cultura científica, de forma a apropriarem-se de seus pressupostos, conhecimentos, conceitos e terminologias. Essa pretensão visa que os alunos possam utilizar desses conhecimentos para interagir e compreender o mundo em que vivem, participando assim de discussões científicas e da tomada de decisões. 
fios, possibilidades e perspectivas do Ensino de Biologia, apontados pela literatura, no que diz respeito ao contexto do ERE. Nesse sentido, esta pesquisa possui um caráter exploratório e nos orientamos em torno da seguinte pergunta: "Como tem se dado às questões de ensino e de aprendizagem, nos distintos aspectos e conteúdos que constituem o campo de estudos da Biologia, de acordo com o cenário exposto pelas recentes pesquisas acadêmicas?". A partir do exposto, apresentamos os procedimentos metodológicos adotados.

\section{PROCEDIMENTOS METODOLÓGICOS}

De natureza qualitativa (FLICK, 2009), a presente pesquisa pode ser caracterizada como um estudo do tipo exploratório e bibliográfico (LÜDKE; ANDRÉ, 1986, GIL, 2008). De acordo com Gil (2008, p. 27):

As pesquisas exploratórias têm como principal finalidade desenvolver, esclarecer e modificar conceitos e ideias, tendo em vista a formulação de problemas mais precisos ou hipóteses pesquisáveis para estudos posteriores. [...] Pesquisas exploratórias são desenvolvidas com o objetivo de proporcionar visão geral, de tipo aproximativo, acerca de determinado fato. Este tipo de pesquisa é realizada especialmente quando o tema escolhido é pouco explorado e torna-se difícil sobre ele formular hipóteses precisas e operacionalizáveis. Muitas vezes as pesquisas exploratórias constituem a primeira etapa de uma investigação mais ampla.

Comumente as pesquisas exploratórias envolvem levantamento bibliográfico e análise de documentos. Todavia, consideramos que esta pesquisa também pode ser classificada como do tipo bibliográfico pelo fato de que, apesar da revisão de literatura ser uma etapa comum a grande parte das pesquisas acadêmicas, pesquisas bibliográficas são "[...] desenvolvidas exclusivamente a partir de fontes bibliográficas" (GIL, 2008, p. 27). Ademais, conforme aponta Gil (2008, p. 27), "parte dos estudos exploratórios podem ser definidos como pesquisas bibliográficas", o que, a nosso ver, é o caso desta pesquisa.

Entre as vantagens da pesquisa bibliográfica está o fato de que, por meio dela, é possível abranger diferentes fenômenos que, muitas vezes, não poderiam ser estudados de forma direta. Um exemplo disso trata-se de quando há uma dispersão muito grande de dados pelo espaço (GIL, 2008). Acreditamos ser esse o caso desta pesquisa, visto que, ao intencionarmos compreender questões rela- 
tivas ao ensino de Biologia, em meio ao ensino remoto, decorrente de um cenário de pandemia, julgamos que muitas poderiam ser as discussões, visto que são múltiplas as realidades educacionais, socioeconômicas, culturais e políticas em nosso país. Em outras palavras, partimos da premissa de que a pandemia não é sentida de igual forma pelos sujeitos (MONTALVÃO NETO et al., 2021), principalmente se considerarmos em meio às desigualdades questões relacionadas à raça, classe e gênero (CARNEIRO, 2019). Destarte, em suma, muitos seriam os dados a serem coletados para que pudéssemos abranger todas as práticas de ensino-aprendizagem, com as suas dificuldades e desafios, realizadas em meio ao ERE. Dessa forma, julgamos como pertinente um olhar mais amplo por meio de reflexões sobre aspectos expostos pela literatura.

As buscas foram realizadas considerando o intervalo temporal até dia 15 de julho de 2021, em três bases de dados, a saber: Google Acadêmico, Portal de Periódicos da CAPES e Scielo. Para a realização das buscas utilizamos a associação dos descritores "Ensino Remoto Emergencial" e "Ensino de Biologia". A partir dessa delimitação de busca, foram encontrados vários trabalhos, como teses, dissertações, capítulos de livros, artigos científicos, entre outros. Todas as páginas obtidas como resultado da busca foram analisadas e somente foram selecionados os artigos científicos para composição do estudo em questão. Deste modo, 12 artigos publicados em periódicos nacionais, que tratam, de alguma forma, sobre questões relativas ao ensino de Biologia em tempos de ERE, foram encontrados. Dos 38 documentos resultantes da busca no Google Acadêmico, apenas 11 resultados correspondiam ao interesse de pesquisa. Já no Portal da CAPES foi encontrado um único artigo ${ }^{1}$, enquanto na Scielo não houve nenhum resultado referente aos termos elencados. Cabe ressaltar que a opção por selecionar apenas artigos científicos publicados em periódicos nacionais para compor o nosso corpus de análise se deve pelo fato de entendermos que este é o meio de maior divulgação e circulação de pesquisas científicas no Brasil2.

\footnotetext{
1 Pesquisando no Portal da Capes por meio do termo "Ensino Remoto Emergencial" foram encontrados 30 resultados. Na pesquisa com o termo "ensino remoto" encontramos 67 resultados. Porém, em meio a esses resultados, apenas 1 estudo relaciona-se ao ensino de Biologia.

2 Academicamente é comum que resultados de teses e dissertações, bem como resultados preliminarmente publicados em anais de eventos, sejam posteriormente publicados em periódicos. É com base nesse pensamento que pontuamos essa conclusão.
} 
A seguir, num movimento de descrição e interpretação, apresentamos as principais tendências, perspectivas, limites e desafios apontados pelas pesquisas encontradas a respeito do ensino de Biologia em meio ao ERE. Para isso, nas Tabelas 1 e 2 caracterizamos essas pesquisas a partir dos seguintes indicadores: a) periódico; b) ano de publicação; c) autores; d) instituição; e) tema; f) público-alvo da pesquisa; g) principais objetivos; h) referencial teórico adotado; i) metodologia; j) principais conclusões. A partir dessa caracterização, realizamos algumas reflexões sobre o tema de interesse com base no corpus apresentado.

\section{RESULTADOS E DISCUSSÃO}

As Tabelas 1 e 2 sintetizam alguns dos principais aspectos apontados pelas doze pesquisas encontradas em nosso levantamento bibliográfico, descrito na seção anterior. Na primeira tabela são apresentados alguns dados mais gerais sobre esses estudos, enquanto na segunda apresentamos os principais enfoques, objetivos, metodologias e resultados das pesquisas.

Tabela 1 - Caracterização geral das pesquisas

\begin{tabular}{|c|c|c|c|c|c|c|}
\hline $\mathbf{N}^{0}$ & Título & Revista & Ano & Autores & Inst. & Tema \\
\hline T1 & $\begin{array}{c}\text { Articulação teoria e } \\
\text { prática no Estágio } \\
\text { Supervisionado em } \\
\text { Biologia: vivência, } \\
\text { formação e percepções } \\
\text { em tempos de pandemia }\end{array}$ & $\begin{array}{l}\text { REnBio - } \\
\text { Revista de } \\
\text { Ensino de } \\
\text { Biologia da } \\
\text { SBEnBio }\end{array}$ & 2021 & $\begin{array}{l}\text { Vanessa } \\
\text { Ap. } \\
\text { Qualho; } \\
\text { Tiago } \\
\text { Venturi }\end{array}$ & $\begin{array}{l}\text { Universidade } \\
\text { Federal do } \\
\text { Paraná }\end{array}$ & $\begin{array}{c}\text { Formação de } \\
\text { professores }\end{array}$ \\
\hline T2 & $\begin{array}{l}\text { O uso de plataformas } \\
\text { digitais como auxílio } \\
\text { no processo ensino e } \\
\text { aprendizagem de } \\
\text { Ciências: um relato } \\
\text { de experiência }\end{array}$ & $\begin{array}{l}\text { Revista } \\
\text { Ensino de } \\
\text { Ciências e } \\
\text { Humanida- } \\
\text { des }\end{array}$ & 2021 & $\begin{array}{l}\text { Patrícia G. } \\
\text { Nogueira, } \\
\text { Felipe S. } \\
\text { Cavalcante } \\
\text { e Renato } \\
\text { A. Lima }\end{array}$ & $\begin{array}{l}\text { Universidade } \\
\text { Federal do } \\
\text { Amazonas }\end{array}$ & $\begin{array}{c}\text { Uso de } \\
\text { plataformas } \\
\text { digitais no } \\
\text { ERE } \\
\text { (Google Meet } \\
\text { e Classroom) }\end{array}$ \\
\hline T3 & $\begin{array}{l}\text { Metodologias ativas e o } \\
\text { ensino remoto de } \\
\text { biologia: uso de recursos } \\
\text { online para aulas } \\
\text { síncronas e assíncronas }\end{array}$ & $\begin{array}{l}\text { Research, } \\
\text { Society and } \\
\text { Development }\end{array}$ & 2020 & $\begin{array}{l}\text { Eliane L. } \\
\text { F. Piffero; } \\
\text { Caroline } \\
\text { P. Coelho; } \\
\text { Renata } \\
\text { G. S. R. } \\
\text { Roehrs }\end{array}$ & $\begin{array}{l}\text { Universidade } \\
\text { Federal do } \\
\text { Pampa }\end{array}$ & $\begin{array}{l}\text { Impactos de } \\
\text { ferramentas } \\
\text { digitais na } \\
\text { aprendizagem }\end{array}$ \\
\hline
\end{tabular}


O ENSINO DE CIÊNCIAS NO BRASIL DURANTE E APÓS A PANDEMIA DA COVID-19: PERSPECTIVAS, DESAFIOS E POSSIBILIDADES

\begin{tabular}{|c|c|c|c|c|c|c|}
\hline T4 & $\begin{array}{c}\text { Estratégias para o } \\
\text { ensino da Covid-19 } \\
\text { utilizando aplicativos de } \\
\text { Histórias em Quadrinhos }\end{array}$ & $\begin{array}{c}\text { Revista } \\
\text { Intersaberes }\end{array}$ & 2020 & $\begin{array}{l}\text { Douglas C. } \\
\text { Amorim e } \\
\text { Cleide J. } \\
\text { S. A. Costa }\end{array}$ & $\begin{array}{l}\text { Universidade } \\
\text { Federal do } \\
\text { Alagoas }\end{array}$ & $\begin{array}{c}\text { Uso de } \\
\text { aplicativos } \\
\text { de criação de } \\
\text { HQs durante e } \\
\text { após } \\
\text { a pandemia } \\
\end{array}$ \\
\hline T5 & $\begin{array}{l}\text { Regências de biologia } \\
\text { no ensino remoto } \\
\text { emergencial: } \\
\text { uma experiência no } \\
\text { programa residência } \\
\text { pedagógica }\end{array}$ & $\begin{array}{c}\text { Revista } \\
\text { Conexão } \\
\text { ComCiência }\end{array}$ & 2021 & $\begin{array}{l}\text { Edilane R. } \\
\text { do } \\
\text { Nascimen- } \\
\text { to; Fabrício } \\
\text { B. Sudério; } \\
\text { Cristiana P. } \\
\text { Santos }\end{array}$ & $\begin{array}{l}\text { Universida- } \\
\text { de Estadual } \\
\text { do Ceará e } \\
\text { Secretaria da } \\
\text { educação }\end{array}$ & $\begin{array}{l}\text { Práticas de } \\
\text { licenciandos } \\
\text { no ensino mé- } \\
\text { dio técnico du- } \\
\text { rante o ERE }\end{array}$ \\
\hline T6 & $\begin{array}{c}\text { O Ensino Remoto Emer- } \\
\text { gencial de Ciências e } \\
\text { Biologia em tempos de } \\
\text { pandemia: com a pala- } \\
\text { vra as professoras da } \\
\text { Regional } 4 \text { da SBENBIO } \\
\text { (MG/GO/TO/DF) }\end{array}$ & $\begin{array}{l}\text { REnBio - } \\
\text { Revista de } \\
\text { Ensino de } \\
\text { Biologia da } \\
\text { SBEnBio }\end{array}$ & 2020 & $\begin{array}{l}\text { Alessandro } \\
\text { T. Barbosa; } \\
\text { Gustavo L. } \\
\text { Ferreira; } \\
\text { Danilo S. } \\
\text { Kato }\end{array}$ & \begin{tabular}{|c} 
Universidade \\
Federal do \\
Tocantins / \\
Instituto Fede- \\
ral de Goiás / \\
Universidade \\
Federal do \\
Triangulo Mi- \\
neiro \\
\end{tabular} & $\begin{array}{c}\text { Proposta de } \\
\text { curso de ex- } \\
\text { tensão com } \\
\text { bionarrativas } \\
\text { sociais } \\
\text { (BIONAS) }\end{array}$ \\
\hline T7 & $\begin{array}{l}\text { Impactos da pandemia } \\
\text { Covid-19 no processo } \\
\text { formativo de } \\
\text { professores de Biologia } \\
\text { de um mestrado } \\
\text { profissional: desafios em } \\
\text { tempos de quarentena }\end{array}$ & $\begin{array}{l}\text { Revista Devir } \\
\text { Educação }\end{array}$ & 2020 & $\begin{array}{l}\text { Douglas C. } \\
\text { Amorim; } \\
\text { Cleide J. A. } \\
\text { Costa }\end{array}$ & $\begin{array}{l}\text { Universidade } \\
\text { Federal de } \\
\text { Alagoas }\end{array}$ & $\begin{array}{l}\text { Impactos do } \\
\text { ERE na } \\
\text { formação de } \\
\text { estudantes de } \\
\text { pós-graduação }\end{array}$ \\
\hline T8 & $\begin{array}{c}\text { Percepções de } \\
\text { professores acerca de } \\
\text { um site que discute a } \\
\text { pandemia da Covid } 19 \\
\text { como questão } \\
\text { sociocientífica }\end{array}$ & $\begin{array}{l}\text { Revista } \\
\text { Práxis }\end{array}$ & 2020 & $\begin{array}{l}\text { Isabel Mar- } \\
\text { tins et al. }\end{array}$ & $\begin{array}{l}\text { Universidade } \\
\text { Federal do } \\
\text { Rio de Janei- } \\
\text { ro / Instituto } \\
\text { Federal -RJ }\end{array}$ & $\begin{array}{l}\text { Percepção de } \\
\text { professores } \\
\text { da educação } \\
\text { básica sobre } \\
\text { questões socio } \\
\text { científicas }\end{array}$ \\
\hline T9 & $\begin{array}{l}\text { Um novo contexto, uma } \\
\text { nova forma de } \\
\text { ensinar: Metodologias } \\
\text { ativas em aulas remotas }\end{array}$ & $\begin{array}{l}\text { Revista de } \\
\text { Estudos e } \\
\text { Pesquisas } \\
\text { sobre Ensino } \\
\text { Tecnológico }\end{array}$ & 2020 & $\begin{array}{l}\text { Eliane L. } \\
\text { F. Piffero; } \\
\text { Caroline } \\
\text { P. Coelho; } \\
\text { Renata G. } \\
\text { Soares; } \\
\text { Rafael } \\
\text { Roehrs }\end{array}$ & $\begin{array}{l}\text { Universidade } \\
\text { Federal do } \\
\text { Pampa }\end{array}$ & $\begin{array}{l}\text { Percepção de } \\
\text { estudantes } \\
\text { sobre o ERE e } \\
\text { o uso de } \\
\text { metodologias } \\
\text { ativas }\end{array}$ \\
\hline T10 & $\begin{array}{l}\text { Trajetória didática no } \\
\text { estudo da diversidade } \\
\text { animal em aulas } \\
\text { remotas: ensaiando o } \\
\text { uso de portfólio para } \\
\text { autoavaliação }\end{array}$ & $\begin{array}{c}\text { Brazilian } \\
\text { Journal of } \\
\text { Development }\end{array}$ & 2021 & $\begin{array}{l}\text { Ceziana A. } \\
\text { C. Araújo } \\
\text { e Elineí } \\
\text { Araújo-de- } \\
\text {-Almeida }\end{array}$ & $\begin{array}{l}\text { Universidade } \\
\text { Federal do } \\
\text { Rio Grande } \\
\text { do Norte }\end{array}$ & $\begin{array}{c}\text { Atividades } \\
\text { desenvolvidas } \\
\text { no ensino de } \\
\text { Zoologia no } \\
\text { Ensino } \\
\text { Superior }\end{array}$ \\
\hline T11 & $\begin{array}{l}\text { Residência Pedagógica: } \\
\text { percepção das } \\
\text { preceptoras acerca da } \\
\text { educação em } \\
\text { sexualidade e gênero }\end{array}$ & $\begin{array}{l}\text { REnBio - } \\
\text { Revista de } \\
\text { Ensino de } \\
\text { Biologia da } \\
\text { SBEnBio }\end{array}$ & 2021 & $\begin{array}{l}\text { Erick H. } \\
\text { S. Paiva; } \\
\text { Evilyn P. } \\
\text { R. Silva; } \\
\text { Zilene M. } \\
\text { P.Soares; } \\
\text { Michel } \\
\text { Mendes }\end{array}$ & $\begin{array}{l}\text { Universidade } \\
\text { Federal de } \\
\text { Goiás / } \\
\text { Universidade } \\
\text { Federal do } \\
\text { Rio de } \\
\text { Janeiro }\end{array}$ & $\begin{array}{c}\text { Educação em } \\
\text { Sexualidade e } \\
\text { Gênero }\end{array}$ \\
\hline
\end{tabular}




\begin{tabular}{|c|c|c|c|c|c|c|}
\hline T12 & $\begin{array}{c}\text { Os entraves do ensino } \\
\text { remoto para formação } \\
\text { acadêmica no curso de } \\
\text { Ciências - Biologia e } \\
\text { Química no IEAA/UFAM1 }\end{array}$ & $\begin{array}{c}\text { Revista Práti- } \\
\text { ca Docente }\end{array}$ & 2021 & $\begin{array}{c}\text { Felipe Au- } \\
\text { gusto M. } \\
\text { Freitas; } \\
\text { Erinéia S. } \\
\text { Santos }\end{array}$ & $\begin{array}{c}\text { Universidade } \\
\text { Federal do } \\
\text { Amazonas }\end{array}$ & $\begin{array}{c}\text { Formação de } \\
\text { professores }\end{array}$ \\
\hline
\end{tabular}

Fonte: Autores.

Por meio da Tabela 1 observamos que metade dos estudos (6) foram publicados no ano de 2020 e, apesar de termos recentemente finalizado o primeiro semestre $^{2}$ de 2021, a outra metade (6) foi publicada em 2021. Ademais, a nosso ver, considerando as múltiplas temáticas, demandas e possibilidades do/no ensino de Biologia, são poucos os estudos encontrados (12). Outrossim, identificamos apenas um estudo sobre a temática publicado em uma revista de Qualis-CAPES A (Revista Práxis). Acreditamos que essas três prerrogativas se devem a questões como, por exemplo, a demora para avaliação por parte dos principais periódicos, bem como devido a dificuldade de publicação impostas por alguns deles. Caberia aqui estudos mais profundos para tecer críticas consistentes, porém, a nosso ver, com os resultados obtidos e por meio de experiências acadêmicas vivenciadas pelos autores deste manuscrito, apontamos que esses podem ser alguns dos indícios para as afirmações expostas.

No que toca às questões de autoria, vemos que há uma diversidade de autores (35) que se debruçam sobre a questão de interesse. De igual modo, encontramos uma diversidade de periódicos (11), repetindo-se apenas um deles nas buscas (RenBio). Em relação às regionais de pesquisa, identificamos uma diversidade de instituições às quais os autores se filiam (14), sendo quatro instituições da região nordeste (UFAL, UECE, SEDUC e UFRN), quatro da região sudeste (UFRJ, UFFRJ, CEFET-RJ e UFTM), três da região centro-oeste (UFT, UFG e IFG), duas da região sul (UFPR e UNIPAMPA) e uma da região norte (UFAM). Em sua maioria, as instituições são de ensino superior.

Acerca dos principais temas das pesquisas, podemos classificá-las principalmente em dois grandes grupos: a) Percepções, estratégias de ensino e for-

$1 \quad$ Único artigo encontrado no Portal de Periódicos da Capes.

$2 \quad$ O presente estudo teve a sua escrita realizada na primeira quinzena de julho de 2021. A revisão bibliográfica foi realizada entre os dias 06 e 08 do referido mês. 
mação docente (T1, T5, T6, T7, T8, T10, T11 e T12); b) Percepções discentes, aprendizagem e uso de tecnologias digitais nos processos de ERE (T2, T3, T4 e T9). A seguir, descrevemos as duas categorias.

A primeira categoria trata-se de um conjunto de pesquisas que estão voltadas às questões relacionadas aos professores, seja em sua formação inicial e/ ou continuada, seja em relação às suas percepções a respeito do ERE. Assim, nesses estudos vemos: a) relatos de experiências de estágio vivenciadas por licenciandos em meio à pandemia; b) pesquisas que se voltam a compreender as estratégias de ensino adotadas por professores em meio à pandemia para tratar um determinado tema; $c$ ) questões relacionadas aos impactos do ERE em cursos de formação inicial ou continuada de professores.

Já a segunda categoria congrega trabalhos que voltam-se às questões da aprendizagem, ou seja, há um enfoque sobre as percepções e desafios vivenciados por alunos. Nessas pesquisas há o interesse em compreender os impactos do uso de tecnologias e de metodologias ativas nas aprendizagens de alunos do ensino básico. Entre as justificativas encontradas nesses trabalhos para tal enfoque, apontamos o que é dito em T-3, em que Piffero et al. (2020a) apontam, com base em outros autores, dizem que a educação, que sempre teve um caráter híbrido, teve-o escancarado com a pandemia, emergindo a necessidade de outras estratégias pedagógicas.

Entre as novas estratégias para enfrentar a atual situação, as metodologias ativas, que colocam o aluno em posições de autonomia e protagonismo, apresentam-se como uma possibilidade (PIFFERO et al., 2020a). Também podemos pontuar o uso de tecnologias digitais com o intuito de ressignificar aprendizagens, quer seja por meio de uma sequência de aulas sobre uma dada temática, como ocorre em T10 (ARAÚJO; ARAÚJO-DE-ALMEIDA, 2021); quer seja pela compreensão das formas de uso de estratégias lúdicas de ensino por meio dessas tecnologias, como ocorre em T4 (AMORIM; COSTA, 2020b).

A seguir, na Tabela 2, apresentamos os principais resultados dos estudos. 
Tabela 2 - Enfoques e principais resultados das pesquisas

\begin{tabular}{|c|c|c|c|c|c|}
\hline $\mathbf{N}^{\circ}$ & Púb. & Objetivo(s) & $\begin{array}{c}\text { Referencial } \\
\text { teórico }\end{array}$ & Metodologia & Conclusões \\
\hline T1 & $\begin{array}{l}\text { Licen- } \\
\text { ciandos }\end{array}$ & $\begin{array}{l}\text { Relatar experiências } \\
\text { de estágio no ERE }\end{array}$ & $\begin{array}{l}\text { Formação de } \\
\text { Professores }\end{array}$ & $\begin{array}{l}\text { Relato de } \\
\text { Experiência }\end{array}$ & $\begin{array}{c}\text { Construção de } \\
\text { conhecimentos } \\
\text { significativos articulando } \\
\text { conhec. biológicos, } \\
\text { pedagógicos e } \\
\text { tecnológicos à formação } \\
\text { docente } \\
\end{array}$ \\
\hline $\mathrm{T} 2$ & $\begin{array}{l}\text { Ensino } \\
\text { Funda- } \\
\text { mental e } \\
\text { Médio }\end{array}$ & $\begin{array}{c}\text { Relatar experiência } \\
\text { com uso de } \\
\text { tecnologia no } \\
\text { ERE de Ciências / } \\
\text { Biologia numa escola } \\
\text { pública de } \\
\text { Porto Velho } \\
\end{array}$ & $\begin{array}{c}\text { Distintas } \\
\text { referências } \\
\text { sobre o ERE }\end{array}$ & $\begin{array}{l}\text { Relato de } \\
\text { Experiência }\end{array}$ & $\begin{array}{l}\text { Apesar do potencial do } \\
\text { uso de plataformas } \\
\text { digitais, elas não } \\
\text { substituem o ensino } \\
\text { presencial. Muitos } \\
\text { alunos têm dificuldades } \\
\text { de acesso à internet. }\end{array}$ \\
\hline T3 & $\begin{array}{l}\text { Ensino } \\
\text { Médio }\end{array}$ & $\begin{array}{l}\text { Verificar o impacto } \\
\text { do uso de ferramen- } \\
\text { tas digitais na } \\
\text { aprendizagem num } \\
\text { contexto } \\
\text { ensino remoto } \\
\end{array}$ & $\begin{array}{l}\text { Perspectiva } \\
\text { freireana (três } \\
\text { momentos } \\
\text { pedagógicos) } \\
\text { / metodologias } \\
\text { ativas } \\
\end{array}$ & $\begin{array}{l}\text { Pesquisa partici- } \\
\text { pante explorató- } \\
\text { ria, descritiva c/ } \\
\text { abordagem qua- } \\
\text { litativa / relato } \\
\text { de experiência }\end{array}$ & $\begin{array}{l}\text { O uso de metodologias } \\
\text { ativas por meio de tec- } \\
\text { nologias digitais permite } \\
\text { a construção da apren- } \\
\text { dizagem de forma inter- } \\
\text { ligada e híbrida }\end{array}$ \\
\hline T4 & $\begin{array}{l}\text { Profes- } \\
\text { sores de } \\
\text { Biologia }\end{array}$ & $\begin{array}{l}\text { Investigar possíveis } \\
\text { estratégias de en- } \\
\text { sino sobre o tema } \\
\text { Covid-19 durante e } \\
\text { após o ERE }\end{array}$ & $\begin{array}{c}\text { Referências } \\
\text { sobre HQ e } \\
\text { ERE }\end{array}$ & $\begin{array}{l}\text { Entrevistas se- } \\
\text { miestruturadas / } \\
\text { Análise de Con- } \\
\text { teúdo }\end{array}$ & $\begin{array}{c}\text { Professores } \\
\text { estabelecem } \\
\text { estratégias de ensino a } \\
\text { partir de suas vivências } \\
\text { com HQs na infância, } \\
\text { embora desconheçam } \\
\text { apps de mediação com } \\
\text { o método. }\end{array}$ \\
\hline T5 & $\begin{array}{l}\text { licen- } \\
\text { ciandos } \\
\text { / ensino } \\
\text { médio } \\
\text { técnico }\end{array}$ & $\begin{array}{c}\text { Relatar regências de } \\
\text { biologia no } 1^{\circ} \text { módulo } \\
\text { do Programa } \\
\text { Residência Pedagó- } \\
\text { gica em uma escola } \\
\text { estadual de educa- } \\
\text { ção profissional do } \\
\text { Crateús-CE } \\
\end{array}$ & $\begin{array}{c}\text { Formação de } \\
\text { Professores e } \\
\text { estudos sobre } \\
\text { o ERE }\end{array}$ & $\begin{array}{c}\text { Relato de expe- } \\
\text { riência com uma } \\
\text { abordagem qua- } \\
\text { litativa }\end{array}$ & $\begin{array}{c}\text { O ERE apresenta } \\
\text { diversas dificuldades, } \\
\text { mas que, ao mesmo } \\
\text { tempo, oferece diversas } \\
\text { possibilidades de apren- } \\
\text { dizagem docente }\end{array}$ \\
\hline T6 & $\begin{array}{l}\text { Profes- } \\
\text { sores }\end{array}$ & $\begin{array}{c}\text { Compreender } \\
\text { desafios e } \\
\text { necessidades } \\
\text { de docentes de } \\
\text { Ciências e/ou } \\
\text { Biologia diante do } \\
\text { ERE }\end{array}$ & $\begin{array}{c}\text { Estudos } \\
\text { decoloniais }\end{array}$ & $\begin{array}{c}\text { Questionário } \\
\text { aplicado a pro- } \\
\text { fessores para } \\
\text { a proposição } \\
\text { de um curso de } \\
\text { extensão on-line } \\
\text { em perspectiva } \\
\text { decolonial e frei- } \\
\text { reana }\end{array}$ & $\begin{array}{c}\text { Os cursistas } \\
\text { trouxeram conflitos } \\
\text { socioambientais } \\
\text { vivenciados em suas } \\
\text { realidades e, a partir } \\
\text { delas, construíram } \\
\text { BIONAS envolvendo a } \\
\text { biodiversidade local e a } \\
\text { memória biocultural que } \\
\text { se remetiam às suas } \\
\text { identidades. }\end{array}$ \\
\hline
\end{tabular}




\begin{tabular}{|c|c|c|c|c|c|}
\hline T7 & $\begin{array}{l}\text { Pós-gra- } \\
\text { duandos }\end{array}$ & $\begin{array}{l}\text { Investigar como a } \\
\text { pandemia influenciou } \\
\text { o processo formativo } \\
\text { dos estudantes do } \\
\text { PPGECIM/UFAL }\end{array}$ & $\begin{array}{c}\text { Formação de } \\
\text { Professores e } \\
\text { estudos sobre } \\
\text { o ERE }\end{array}$ & $\begin{array}{c}\text { Abordagem } \\
\text { qualitativa e } \\
\text { exploratória / } \\
\text { entrevistas se- } \\
\text { miestruturadas / } \\
\text { Análise do } \\
\text { Conteúdo com } \\
\text { auxílio } \\
\text { de software }\end{array}$ & $\begin{array}{l}\text { Os efeitos da pandemia } \\
\text { no processo formativo } \\
\text { dos mestrandos } \\
\text { alteraram rotinas, } \\
\text { produção textual, } \\
\text { gestão do tempo e } \\
\text { produção do produto } \\
\text { educacional }\end{array}$ \\
\hline T8 & $\begin{array}{l}\text { Profes- } \\
\text { sores } \\
\text { da edu- } \\
\text { cação } \\
\text { básica }\end{array}$ & $\begin{array}{c}\text { Identificar a } \\
\text { percepção } \\
\text { de professores da } \\
\text { educação } \\
\text { básica sobre um site } \\
\text { desenvolvido pelo } \\
\text { Instituto Nutes-UFRJ } \\
\text { durante a pandemia } \\
\text { da Covid19 }\end{array}$ & TDIC's & $\begin{array}{l}\text { Análise do } \\
\text { Conteúdo - } \\
\text { análise de } \\
\text { questionários } \\
\text { que embasaram } \\
\text { a montagem do } \\
\text { site }\end{array}$ & $\begin{array}{c}\text { Tanto o site } \\
\text { quanto as questões } \\
\text { sociocientíficas foram } \\
\text { apontados como } \\
\text { relevantes } \\
\text { pelos professores, } \\
\text { principalmente } \\
\text { no contexto pandêmico }\end{array}$ \\
\hline T9 & $\begin{array}{l}\text { Ensino } \\
\text { Médio }\end{array}$ & $\begin{array}{c}\text { Averiguar a } \\
\text { percepção de alunos } \\
\text { de uma } \\
\text { escola pública e uma } \\
\text { privada sobre aulas } \\
\text { remotas e a possibili- } \\
\text { dade do uso } \\
\text { de metodologias } \\
\text { ativas }\end{array}$ & $\begin{array}{l}\text { Metodologias } \\
\text { ativas e } \\
\text { estudos sobre } \\
\text { o ERE }\end{array}$ & $\begin{array}{l}\text { abordagem } \\
\text { qualitativa, } \\
\text { exploratória } \\
\text { e descritiva / } \\
\text { questionário } \\
\text { on-line }\end{array}$ & $\begin{array}{c}\text { Importância do uso de } \\
\text { metodologias ativas nas } \\
\text { aulas remotas para a } \\
\text { aprendizagem } \\
\text { significativa e o aluno } \\
\text { deve ser o centro } \\
\text { do ensino, agindo e } \\
\text { refletindo sobre suas } \\
\text { ações }\end{array}$ \\
\hline T10 & $\begin{array}{l}\text { Gra- } \\
\text { duandos } \\
\text { em Eco- } \\
\text { logia }\end{array}$ & $\begin{array}{c}\text { Destacar } \\
\text { percursos para } \\
\text { estudo de táxons } \\
\text { animais, avaliando } \\
\text { efeitos positivos de } \\
\text { um aporte reflexivo } \\
\text { em torno da produ- } \\
\text { ção e sistematização } \\
\text { de conhecimento } \\
\text { numa perspectiva da } \\
\text { biodiversidade }\end{array}$ & $\begin{array}{l}\text { Referências } \\
\text { sobre } \\
\text { o Ensino de } \\
\text { Zoologia }\end{array}$ & $\begin{array}{c}\text { Relato } \\
\text { de Experiência }\end{array}$ & $\begin{array}{c}\text { O processo } \\
\text { oportunizou aos autores } \\
\text { irem além da sala de } \\
\text { aula, ao documentarem } \\
\text { as vivências em relato } \\
\text { de experiência }\end{array}$ \\
\hline T11 & $\begin{array}{l}\text { Profes- } \\
\text { soras } \\
\text { da rede } \\
\text { básica }\end{array}$ & $\begin{array}{c}\text { Investigar concep- } \\
\text { ções de preceptoras } \\
\text { da Residência } \\
\text { Pedagógica da UFG } \\
\text { sobre Educação em } \\
\text { Sexualidade/Gêne- } \\
\text { ro, compreendendo } \\
\text { como as temáticas } \\
\text { podem contribuir na } \\
\text { formação inicial e } \\
\text { continuada de pro- } \\
\text { fessores }\end{array}$ & $\begin{array}{c}\text { Sexualidade e } \\
\text { Gênero }\end{array}$ & $\begin{array}{l}\text { Análise de Con- } \\
\text { teúdo / análise } \\
\text { das respostas } \\
\text { de questionário }\end{array}$ & $\begin{array}{l}\text { As professoras não } \\
\text { tiveram contato com a } \\
\text { temática durante sua } \\
\text { graduação, } \\
\text { evidenciando } \\
\text { uma perspectiva } \\
\text { biologicista em suas } \\
\text { propostas pedagógicas }\end{array}$ \\
\hline
\end{tabular}




\begin{tabular}{|c|c|c|c|c|c|}
\hline T12 & $\begin{array}{c}\text { Avaliar os impactos } \\
\text { do ensino remoto no } \\
\text { ensino e no } \\
\text { aprendizado } \\
\text { Licen- } \\
\text { ciandos }\end{array}$ & $\begin{array}{c}\text { TIC's, } \\
\text { netodologias } \\
\text { ativas } \\
\text { Cienciatura em } \\
\text { Biologia e Química } \\
\text { do IEAA-UFAM }\end{array}$ & $\begin{array}{c}\text { Pesquisa de } \\
\text { e estudos } \\
\text { sobre o ERE } \\
\text { campo de natu- } \\
\text { reza qualitativa / } \\
\text { questionário } \\
\text { semiestruturado }\end{array}$ & $\begin{array}{c}\text { Retorno positivo dos } \\
\text { alunos e as TIC's são } \\
\text { ferramentas importantes } \\
\text { para a aprendizagem } \\
\text { significativa de } \\
\text { determinados } \\
\text { conteúdos }\end{array}$ \\
\hline
\end{tabular}

Fonte: Autores.

Como apontado, há um grande foco das pesquisas no que toca ao público-alvo docente, visto que muitas delas preocupam-se com questões relacionadas às suas práticas e/ou formação inicial ou continuada. Como mostra a Tabela 2, há um considerável número de pesquisas que buscam relatar experiências em diferentes níveis de ensino, seja com enfoque na formação docente ou nos processos de ensino-aprendizagem de discentes. Entre as metodologias destacadas apontamos que as pesquisas utilizam-se de abordagens qualitativas para a elaboração de relatos de experiência (T1, T2, T3, T5, T10) ou de questionários/ entrevistas semiestruturados (T4, T6, T7, T8, T9, T11 e T12) sendo que, em sua maioria, esses dados coletados são analisados por meio da técnica de Análise de Conteúdo (BARDIN, 1979).

Por meio das conclusões apresentadas na Tabela 2, parece-nos, então, que, apesar das dificuldades impostas pelo ERE, em tempos de pandemia emergem estratégias de resistência, subversão e de ressignificação, a partir de práticas transgressoras, implementadas em diferentes instâncias (no ensino básico, técnico, superior e na formação continuada de professores), para a minimização e/ou superação das adversidades deste momento de crise. Há, portanto, denúncias e anúncios materializando-se por meio de investigações que buscam tanto identificar as percepções de estudantes e de docentes sobre o atual momento, quanto buscam refletir sobre as atividades idealizadas neste âmbito.

Por exemplo, em T9 (PIFFERO et al., 2020b), além da síntese apresentada na Tabela 2, os autores apontam que, entre os resultados relativos às percepções dos alunos sobre o ERE, o acesso pleno à internet é um dos fatores que mais prejudicaram o desenvolvimento de aulas remotas. Ademais, esses discentes apontam fatores do tipo comodidade e segurança como alguns dos pontos considerados positivos no atual contexto. 
Algo similar é apontado em outros trabalhos, como, por exemplo, no caso do T12 (FREITAS; SANTOS, 2021), no qual os autores trazem em suas conclusões que, no questionário respondido pelos alunos, há um apontamento referente a pertinência da proposta de ensino remoto implementada pela UFAM, principalmente ao apresentar-se como uma medida paliativa que possibilitou a continuidade dos estudos mesmo diante da suspensão das aulas presenciais. No entanto, os autores concluem que ainda é necessário pensar sobre outras metodologias que possam amenizar a situação do momento. Ou seja, apesar de resultados positivos em meio ao contexto de ERE, isso não significa que as aulas remotas substituem as aulas presenciais, visto que, nos trabalhos que encontramos em nossas buscas, tal como, por exemplo, em T2, essa questão é evidenciada na voz de estudantes de educação básica e, em outros trabalhos, também na voz de professores.

No que diz respeito aos processos formativos, no T1, Qualho e Venturi (2021) trazem contribuições de como o contexto pandêmico e o ERE tiveram impactos na realização do estágio supervisionado em um curso de Licenciatura em Ciências Biológicas. Segundo os autores, a maior limitação nesse processo foi a escassez ou ausência de comunicação com os alunos da educação básica, não permitindo uma avaliação do processo de ensino-aprendizagem das atividades propostas, em concordância com outros trabalhos como o de Souza e Ferreira (2020, p. 15), quando afirmam que "[...] a ausência da vivência na escola na condição de estagiário e como instituição formadora e educativa é uma catástrofe para nossas vidas em sociedade". Qualho e Venturi (2021) também reconhecem que o estágio realizado remotamente proporcionou refletir e utilizou de diversas ferramentas tecnológicas e educativas, integrando-as ao processo formativo.

O impacto na formação continuada de professores também apresentou dicotomias, conforme abordado no T7, por Amorim e Costa (2020a), em um curso de pós-graduação do Mestrado Profissional. Para os pesquisadores, a formação permanente dos professores compreende "o que" e "como" os professores vão ensinar, sendo um percurso influenciado por fatores externos. Dessa forma, mudanças no cenário educacional, político e econômico implicará em novas formas de ensinar e aprender, levando a uma reflexão da práxis docente. Assim, por meio de entrevistas com mestrandos, Amorim e Costa (2020a) observam que 
questões ligadas à gestão do tempo, aos aspectos emocionais e ao andamento dos estudos são os principais impactos gerados pela adoção do ERE na pós-graduação, concluindo que se "[...] por um lado, falta de contato pessoal e baixa qualidade de acesso à internet são vistos como aspectos negativos; por outro, a continuidade dos estudos e produtividade nas aulas remotas foram os pontos positivos" (AMORIM; COSTA, 2020a, p. 94) entre os pós-graduandos.

Em uma experiência de elaboração de um curso em perspectiva freireana e decolonial, proposta por Barbosa e seus colaboradores (T6), realizou-se um trabalho de formação continuada, a partir da produção de bionarrativas sociais (BIONAS) ${ }^{1}$ com professoras de Biologia de diferentes regionalidades, culturas e formações. A partir desse trabalho, os autores observaram que a construção de BIONAS permitiu a abordagem de conflitos socioambientais e envolveram a biodiversidade local e memória biocultural dos participantes, ou seja, permitiu a expressão das identidades das docentes. Todavia, os autores apontam como principais desafios "[...] a falta de formação e experiência prévia das professoras para produzirem as atividades remotamente, as habilidades básicas e intermediária com as TDICs e a conciliação do ensino remoto com os cuidados domésticos" (BARBOSA; FERREIRA; KATO, 2020, p. 379).

Tais aspectos que aqui apontamos reiteram algumas tentativas observadas nesses estudos de resistência e ressignificação diante da crise vivenciada.

\section{CONSIDERAÇÕES FINAIS}

Ao longo dessa pesquisa de caráter exploratório refletimos sobre algumas das principais dificuldades, desafios, possibilidades e perspectivas do Ensino de Biologia apontados na literatura, mais especificamente no que diz respeito ao ERE, colocando em questão de que forma tem se dado o trabalho com situações de ensino-aprendizagem nos distintos contextos que constituem o campo de estudos da Biologia. Nesse sentido, por meio do levantamento bibliográfico e da análise documental empreendida, compreendemos que o cenário vivenciado tem

1 De acordo com Barbosa, Ferreira e Kato (2020, p. 384), "as BIONAS podem ser definidas como um recurso educacional aberto (REA) que incorpora elementos multimodais para entoar diferentes vozes e histórias locais por meio de narrativas digitais e da relação entre arte e ciência". 
sido palco de resistências e tentativas de ressignificação nas variadas esferas: seja nos cursos de formação inicial e continuada, seja nas aulas remotas.

Subsidiados por variadas correntes teóricas, observamos o movimento de reflexão sobre a prática do professor de Biologia no contexto pandêmico enquanto campo de transformação dos processos educativos, evidenciando assim as complexidades imprevisíveis com as quais o professor em seu exercício de práxis é posto em contato. Compreendemos assim que, apesar do início crítico e problemático, característicos das mudanças abruptas do ensino presencial para a modalidade remota, a literatura aponta sucessos em novas estratégias e possibilidades de enriquecimento formativo, em aspectos antes pouco considerados, tais como, por exemplo, o uso das Tecnologias Digitais de Informação e Comunicação (TDIC's). Destarte, em síntese, em relação ao Ensino de Biologia praticado no contexto de crise ocasionado pela pandemia da Covid-19, concluímos que a literatura tem se mostrado ativa e reagente, na busca compromissada por formar alunos e professores, mesmo diante de adversidades políticas e sanitárias.

Por fim, apontamos que muitas outras discussões poderiam ser destacadas com base nesses (e em outros) estudos sobre a atual conjuntura. Aqui pontuamos questões que, a nosso ver, são algumas das mais centrais do ponto de vista da leitura que fizemos, não esgotando as possibilidades de discussão. Outrossim, outros trabalhos, teóricos e/ou empíricos, se fazem necessários para amenizar as problemáticas do ERE e apontar para possibilidades que visem colaborar com uma perspectiva de ensino de Biologia transgressora e crítico-reflexiva.

\section{REFERÊNCIAS}

ALMEIDA, M. J. M.; SILVA, A. C. Leitura de textos de cientistas por um licenciando: uma possibilidade de acesso a discursos que contrastam com o das pós-verdades. Caderno Brasileiro de Ensino de Física, v. 37, n. 3, p. 1659-1683, 2020.

AMORIM, D. C.; COSTA, C. J. A. Impactos da pandemia Covid-19 no processo formativo de professores de Biologia de um mestrado profissional: desafios em tempos de quarentena. Revista Devir Educação, v. 2, n. 4, p. 80-103, 2020a.

Estratégias para o ensino da Covid-19 utilizando aplicativos de histórias em quadrinhos. REVISTA INTERSABERES, v. 15, n. 36, p. 556-580, 2020 b. 
ARAÚJO, C. A. C.; ARAÚJO-DE-ALMEIDA, E. Trajetória didática no estudo da diversidade animal em aulas remotas: ensaiando o uso de portfólio para autoavaliação. Brazilian Journal of Development, v. 7, n. 1, p. 9474-9483, 2021.

BARBOSA, A. T.; FERREIRA, G. L.; KATO, D. S. O Ensino Remoto Emergencial de Ciências e Biologia em tempos de pandemia: com a palavra as professoras da Regional 4 da SBENBIO (MG/GO/TO/DF). Revista de Ensino de Biologia da SBEnBio, v. 13, n. 2, p. 379-399, 2020.

BARDIN, L. Análise de conteúdo. Lisboa: Edições 70, 1979. 229 p.

BRASIL. Ministério da Saúde. Portaria N. 188, de 3 de fevereiro de 2020. Declara Emergência em Saúde Pública de importância Nacional (ESPIN) em decorrência da Infecção Humana pelo novo Coronavírus (2019-nCoV). Brasília: Diário Oficial da União: seção I, edição 24-A, 2020b. Disponível em: http://www.in.gov. $\mathrm{br} / \mathrm{en} / \mathrm{web} / \mathrm{dou} /-/$ portaria-n-188-de-3-de-fevereiro-de-2020-241408388. Acesso em: 09 jul. 2021.

CARNEIRO, S. Enegrecer o feminismo: a situação da mulher negra na América Latina a partir de uma perspectiva de gênero. In: HOLLANDA, H. B. (org.). Pensamento feminista - conceitos fundamentais, Rio de Janeiro: Bazar do tempo, 2019.

CUNHA, L. F. F.; SILVA, A. S.; SILVA, A. P. O ensino remoto no Brasil em tempos de pandemia: diálogos acerca da qualidade do direito e acesso à educação. $\mathbf{R e}-$ vista Com Censo: Estudos Educacionais do Distrito Federal, Brasília, v. 7, n. 3, p. 27-37, 2020.

FLICK, U. Qualidade na pesquisa qualitativa. Porto Alegre: Artmed, 2009. 196p.

GIL, A. C. Métodos e técnicas de pesquisa social. 6. ed. São Paulo: Atlas, 2008.

HODGES, C.; MOORE, S.; LOCKEE, B.; TRUST, T.; BOND, A. The difference between emergency remote teaching and online learning. Trad. Danilo Aguiar, Américo N Amorim, Lídia Cerqueira. Revista da Escola, Professor, Educação e Tecnologia, v. 2, 2020.

LÜDKE, M.; ANDRÉ, M. E. D. A. Pesquisa em educação: abordagens qualitativas. São Paulo: EPU, 1986. 
MBEMBE, A. Necropolítica. Arte \& Ensaios, v. 32, n. 1, p. 123-151, 2016.

MONTALVÃO NETO, A. L.; MIGUEL, K. S.; SIMAS FILHO, J. P.; DELLA JUSTINA, L. A. A Educação de Jovens e Adultos em um cenário de pandemia: reflexões docentes. South American Journal of Basic Education, Technical and Technological, v. 8, n. 1, p. 352-369, 2021.

MONTALVÃO NETO, A. L.; SILVA FILHO, J. G.; ROCHA, G. G. S. Notas sobre contextos pandêmicos: reflexões a partir de políticas de morte representadas na série animada monster. Revista FORPROLL, v. 5, Ed. Esp., p. 188-208, 2021a.

Implicações Históricas e Políticas no Século XXI: algumas reflexões sobre a educação contemporânea. In: MONTALVÃO NETO, A. L.; SILVA FILHO, J. G.; ROCHA, G. G. S. (Orgs.). Educação contemporânea em foco: diálogos a partir de múltiplas perspectivas. Editora Peixe Azul, 2021b, p. 16-34.

MORAIS, W. R.; MORAES, F. N. Discursos sobre a Ciência e as concepções de formação científica na era das pós-verdades. In: MONTALVÃO NETO, A. L.; SIMAS FILHO, J. P. (Orgs.). Linguagem na interface com o Ensino de Ciências. 1 ed. Catu: Bordô-Grená, v. 1, p. 51-66, 2021.

MORAES, F. N.; MONTALVÃO NETO, A. L.; MORAIS, W. R. O não-lugar da biotecnologia e a pandemia da Covid-19 no Brasil. Gláuks - Revista De Letras E Artes, v. 21, n. 1, p. 303-326, 2021.

OXFORD. "Post-truth". Oxford Dictionaries. Oxford: Oxford University Press, 2021. Disponível em: https://en.oxforddictionaries.com/definition/post-truth. Acesso em: 09 jul. 2021.

PIFFERO, E. L. F.; COELHO, C. P.; SOARES, R. G.; ROEHRS, R. Metodologias ativas e o ensino remoto de biologia: uso de recursos online para aulas síncronas e assíncronas. Research, Society and Development, v. 9, n. 10, p. 1-19, 2020a.

Um novo contexto, uma nova forma de ensinar: Metodologias ativas em aulas remotas. Revista de Estudos e Pesquisas sobre Ensino Tecnológico, v. 6, Ed. Espec., p. 1-18, 2020b.

QUALHO, V. A.; VENTURI, T. Articulação teoria e prática no estágio supervisionado remoto em biologia: Vivência, formação e percepções em tempos de pandemia. Revista de Ensino de Biologia da SBEnBio, v. 14, n. 1, p. 487-504, 2021. 
REIS, P. Desafios à educação em ciências em tempos conturbados. Ciência \& Educação, Bauru, v. 27, p. 1-9, 2021.

SASSERON, L. H.; CARVALHO, A. M. P. Alfabetização científica: uma revisão bibliográfica. Investigações em Ensino de Ciências, v. 16, n. 1, pp. 59-77, 2011.

SOUZA, E. M. F.; FERREIRA, L. G. Ensino remoto emergencial e o estágio supervisionado nos cursos de licenciatura no cenário da pandemia Covid 19. Revista Tempos Espaços Educativos, v. 13, n. 32, 2020.

WHO. World Health Organization: Coronavirus disease (COVID-19). 2020. Disponível em: https://www.who.int/emergencies/diseases/novel-coronavirus-2019/ question-andanswers-hub/q-a-detail/coronavirus-disease-covid-19. Acesso em: 09 jul. 2021. 
doi 10.48209/978-65-89949-13-2

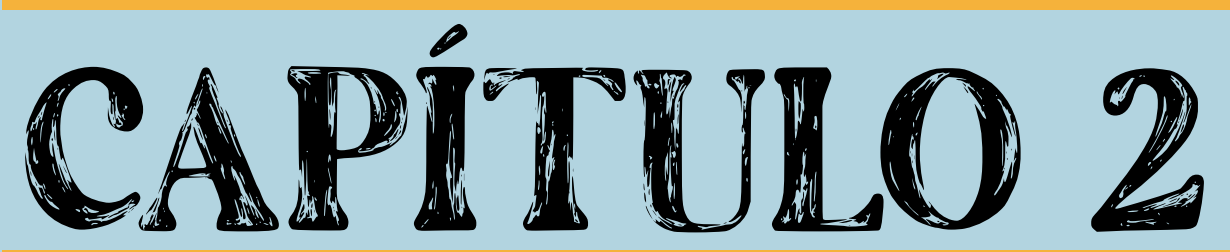

LÁ VEM A DENGUE: UMA PROPOSTA DE SENSIBILIZAÇÃO A PARTIR DO USO DE METODOLOGIAS ATIVAS EM TEMPOS DE ENSINO REMOTO

Allana Carla Garcia dos Santos Marcelo Alberto Elias Margarida Maria Sandeski Alex Sandro Barros de Souza Renata Rúbia Ota 


\section{INTRODUÇÃO}

A dengue tornou-se, ao longo dos anos, um grande desafio para a saúde no mundo, atingindo principalmente países com clima tropical (TIMERMAN; NUNES; LUZ, 2012). No Brasil, a situação é preocupante, pois os centros urbanos favorecem a dispersão e o aumento das populações do mosquito transmissor da dengue. Dessa maneira, o vírus se instalou e se expandiu, tornando-se um grave problema de saúde pública (TEIXEIRA; BARRETO; GUERRA, 1999).

Segundo o Ministério da Saúde, no período de dezembro de 2019 até 13 de março de 2020 foram notificados 390.684 casos prováveis de dengue no país, classificando-a assim como epidemia (BRASIL, 2020). Nesse sentido, o Ministério da Saúde tem realizado algumas ações para combater o mosquito da dengue, tais como: Programas específicos e permanentes de combate à dengue; campanhas informativas; mobilização de pessoas; vigilância epidemiológica e entomológica; entre outras ações que envolvem Estados e Municípios (BRASIL, 2002).

Podemos citar como exemplo dessas ações a cidade de Umuarama-PR, que, segundo informações da Secretaria de Saúde do município, conta com projetos de combate à dengue denominados: a) Bairro saudável, em que é feito um "arrastão" com caminhões, disponibilizados pela prefeitura, para recolher entuIhos e materiais que possam acumular água; b) Projeto orquídeas, projeto no qual orquídeas são plantadas nos ocos das árvores, visando eliminar criadouros do mosquito; c) Intensificação das ações dos agentes de combate a endemias, aumentando o número e locais vistoriados; d) Vigi-Água, onde os agentes da vigilância ambiental fazem semanalmente a análise da água potável consumida pela população local, afim de detectar problemas na qualidade da água. Ademais, no estado do Mato Grasso do Sul (MS), que está entre os estados brasileiros com os maiores índices de casos de dengue, segundo o boletim epidemiológico de 2020 do Ministério da Saúde, será utilizado um método inovador, "Método Wolbachia", desenvolvido pelo instituto Oswaldo Cruz em parceria com o Sistema Único de Saúde (SUS), que consiste em infectar mosquitos Aedes aegypti com a Wolbachia, uma bactéria intracelular, reduzindo assim a capacidade de o mosquito transmitir dengue (BRASIL, 2020). 
Apesar de medidas como essas, a principal ação contra a dengue é a atuação consciente e permanente da população, conforme apontam as Diretrizes Curriculares Nacionais para a Educação Ambiental (BRASIL, 2012), que, em seu Artigo $2^{\circ}$, salienta que:

[...] a educação ambiental é uma dimensão da educação, é atividade intencional da prática social, que deve imprimir ao desenvolvimento individual um caráter social em sua relação com a natureza e com os outros seres humanos, visando potencializar essa atividade humana com a finalidade de torná-la plena de prática social e de ética ambiental. (BRASIL, 2012, p. 2).

Contudo, o ser humano, por meio de suas relações sociais, historicamente construiu a sociedade nos moldes tal como ela se apresenta. Todavia, enquanto sujeitos, temos o poder de buscar meios de transformação. Isso porque, não há prática educativa sem sociedade e nem sociedade sem a prática educativa. Nesse sentido, para Freire (1996), o indivíduo não deve ser apenas o objeto da história, mas sujeito da produção do saber, participando ativamente da vida em sociedade. Ou seja, mais do que conteúdo, o educando deverá refletir sobre os sentidos e os significados do(s) conhecimento(s).

A educação, enquanto processo permanente, é uma ferramenta para tornar o indivíduo ativo na sociedade, contribuindo para a sua vida social (FREIRE, 1993). Por essa razão, a atividade educativa se dá nos espaços formais (escolas, universidades e outros espaços de ensino) e não formais da sociedade (igrejas, instituições educativas, empresas, grupos sociais, entre outras), sempre seguindo uma determinada organização. Da mesma forma, o ensino de ciências precisa estar interconectado com a realidade do aluno (BRASIL, 2000). Por vezes, por se tratar de assuntos complexos, para a sua compreensão, esse ensino precisa estar envolvido com questões históricas, sociais, econômicas, éticas e culturais.

Apesar da importância do diálogo das questões científicas com as diversas questões sociais ser uma necessidade constante, atualmente as atenções voltam-se à pandemia da Covid-19. Todavia, a dengue não pode ser esquecida, pois ela continua como um grande problema de saúde pública. Durante esses tempos de distanciamento social, é importante estimular os alunos e a sua família a manterem hábitos saudáveis, levando em consideração questões como a alimenta- 
ção, a saúde, a higiene pessoal, entre outros fatores. Assim, há a preocupação em incentivar as pessoas a manterem o ambiente de casa sempre limpo, a fim de evitar possíveis focos do mosquito transmissor da dengue.

Nessa concepção de tornar o educando um indivíduo ativo, e diante da nova perspectiva sobre a educação em tempos de pandemia, surgem as metodologias ativas, com o objetivo de impulsionar o desenvolvimento de competências e habilidades no processo de aprendizagem. As metodologias ativas são definidas por uma variedade de estratégias de ensino, tais como: sala de aula invertida, estudos de caso, projetos, aprendizagem baseada em problemas, entre outros (CRUZ, 2018).

Contudo, não podemos desconsiderar o novo cenário educacional instalado pela pandemia provocada pela Covid-19. A escola e todos os seus agentes precisaram se "reinventar", e ainda continuam imersos nesse ambiente novo para todos, em que a presencialidade foi interrompida. Novas metodologias, novas tecnologias e constantes modificações estão sempre presentes no atual cenário (ANTUNES-NETO, 2020).

Nesse contexto, a partir de metodologias ativas, neste trabalho visamos apresentar algumas propostas metodológicas, no âmbito do ensino de ciências e biologia e em tempos de pandemia, que envolvem a abordagem da problemática "Dengue" na educação básica, e que podem ser realizadas de maneira virtual ou híbrida nos anos finais do ensino fundamental $\left(6^{\circ}, 7^{\circ}, 8^{\circ}\right.$ e $9^{\circ}$ anos). Para isso, organizamos diferentes propostas didáticas que se aplicam à temática a partir de três metodologias ativas, com enfoque especial às questões vivenciadas em tempos de pandemia da COVID-19, mas que também são úteis em outros momentos, em que o ensino presencial não seja uma plena possibilidade.

\section{METODOLOGIA}

Caracterizado como de natureza aplicada, este estudo apresenta uma abordagem qualitativa, com objetivo descritivo e utilizando a pesquisa bibliográfica como procedimento técnico (SOUZA, 2014). 
Para a revisão bibliográfica foi utilizado o Google acadêmico, aplicando o filtro dos últimos cinco anos e utilizando como palavras-chave para as buscas os termos "estudo de caso", "ensino a partir de situação problema" e "ensino a partir de projetos". A revisão não objetivou esgotar a literatura sobre as metodologias de interesse, mas dar suporte teórico e metodológico para as propostas apresentadas.

Procedimentalmente, após a revisão bibliográfica, foram elaboradas propostas metodológicas utilizando as três metodologias ativas para abordar a temática "Dengue" nas séries finais do ensino fundamental $\left(6^{\circ}, 7^{\circ}, 8^{\circ} \mathrm{e}\right.$ $9^{\circ}$ anos). As metodologias utilizadas foram escolhidas visando principalmente uma prática pedagógica não presencial, e são, a saber: estudo de caso, ensino a partir de situação problema e ensino a partir de projetos (MOREIRA; SOUZA, 2016, BASTOS, 2006). A seguir, descrevemos essas metodologias com base na literatura.

Segundo Moreira e Souza (2016), o ensino baseado em estudo de caso e a problematização dos conteúdos têm se mostrado excelentes ferramentas para desenvolver nos alunos habilidades de autonomia e a tomada de decisões. De acordo com Sá e Queiroz (2009), o estudo de caso é uma metodologia em que os estudantes direcionam a sua própria aprendizagem enquanto investigam a ciência envolvida em situações complexas, reais ou simuladas. Assim, segundo os autores, essa metodologia possibilita que a aula seja contextualizada a partir de fatos do cotidiano, gerando um interesse maior dos estudantes pela aula ao relacionar o conhecimento científico com o seu dia a dia. Nesse tipo de metodologia o professor atua como mediador, fazendo o estudante refletir sobre as questões, e é o aluno que identifica os problemas, coleta as informações, cria as hipóteses, argumenta com os seus colegas e toma uma decisão (SENAC, 2018).

Já o processo de Aprendizagem Baseada em Problemas é um conjunto de procedimentos em que os alunos são apresentados a algum problema, organizando e discutindo as suas ideias com a finalidade de resolução deste problema proposto pelo professor (TAN, 2003). O professor atua então como um facilitador, direcionando e motivando as ações, porém, ele nunca fornece respostas diretas aos alunos, ficando sobre o aluno a responsabilidade individual e coletiva para levantar estratégias e solucionar o problema. Dessa maneira, trata-se de um processo autorreflexivo (HUNG; JONASSEN; LIU, 2008). 
No mesmo sentido, a Aprendizagem Baseada em Projetos coloca os alunos em situações-problema para que ele possa compreender, analisar e projetar um meio para solucioná-lo (SENAC, 2018). Para Moran (2018, p. 17), essa é uma metodologia que envolve questões interdisciplinares, e na qual os alunos resolvem um problema ou desenvolvem um projeto que tenha ligação com o seu cotidiano. Esse processo pode ser individual ou em grupo. Destarte, de acordo com Barbosa e Moura (2013), os projetos podem ser classificados em três categorias:

- Projeto construtivo: construir algo novo, propor uma solução nova para um problema ou situação.

- Projeto investigativo: empregar o método científico no desenvolvimento de uma pesquisa sobre uma questão ou situação.

- $\quad$ Projeto didático (ou explicativo): procura explicar e responder questões do tipo: "Como funciona? Para que serve? Como foi construído?"

A seguir apresentamos as propostas de atividades por nós elaboradas para a abordagem da temática "Dengue" em contextos de ensino não-presencial com base nessas três metodologias.

\section{RESULTADOS E DISCUSSÃO}

Usando como fio condutor a problemática da dengue e a sensibilização no espaço escolar em tempos não presenciais de ensino, apresentamos três propostas, conforme exposto nas tabelas 01,02 e 03. 
Tabela 01: Proposta didática pautada na metodologia de estudo de caso para trabalhar a temática "Dengue".

\begin{tabular}{|c|c|}
\hline $\begin{array}{c}\text { METODOLOGIA } \\
\text { ATIVA }\end{array}$ & PROPOSTA DIDÁTICA \\
\hline Estudo de caso & 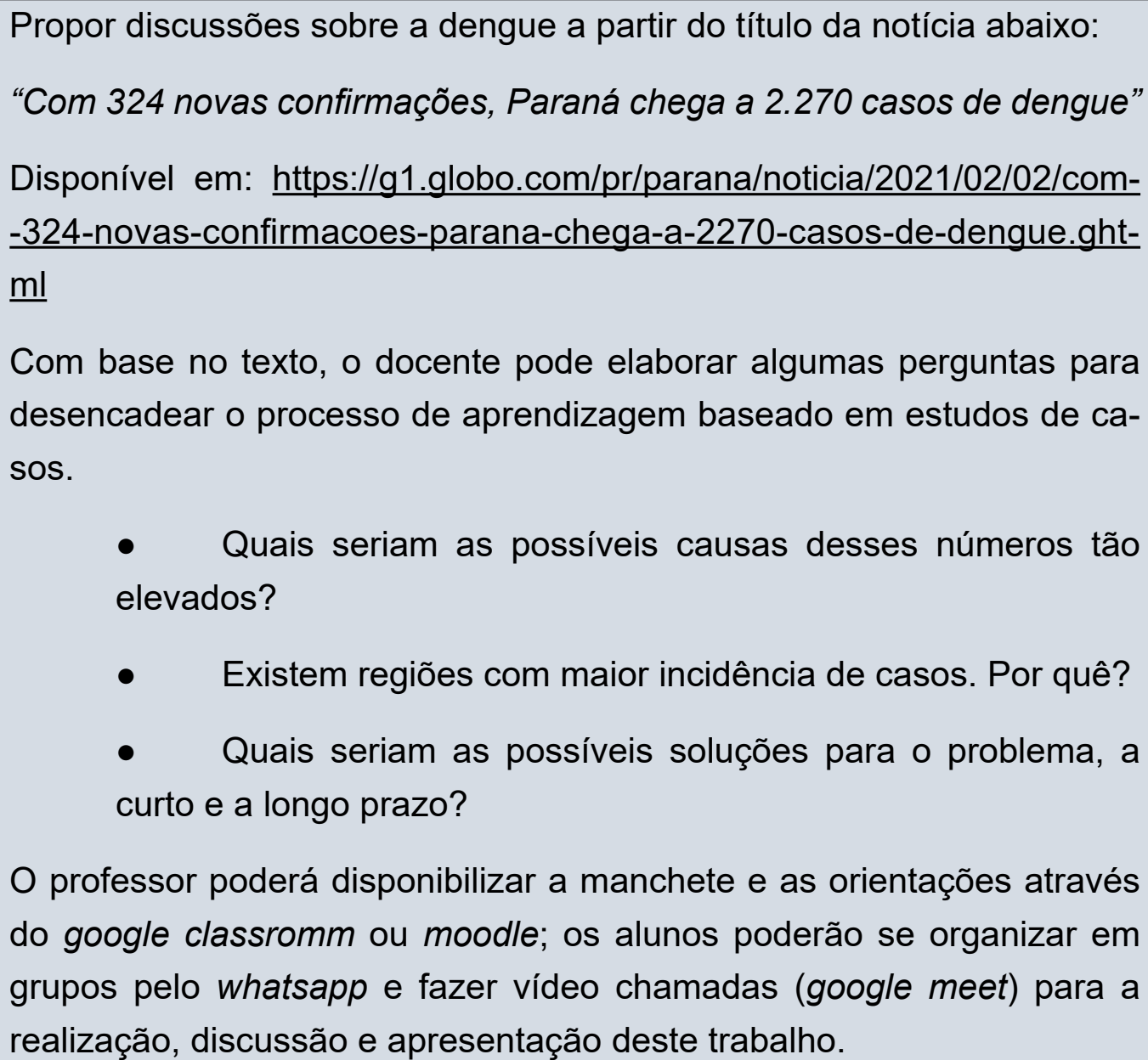 \\
\hline
\end{tabular}

Fonte: Autores

Levando em consideração a realidade do ensino não presencial, a partir dessa proposta, é possível dar liberdade aos estudantes para que possam acessar a reportagem e explorar o conteúdo, buscando então estudar o "caso". Como sugestão aos estudantes em situação de vulnerabilidade que não tenham acesso à internet, poderia ser disponibilizada a impressão da reportagem, sempre considerando a realidade e as possibilidades de cada espaço escolar.

Essa metodologia se mostrou eficiente em outros estudos, tal como o de Elias e Ricco (2020), em que os autores indicam que o estudo de caso se mostrou como uma possibilidade interessante diante da proposta aplicada por eles, visto que, a partir de um caso envolvendo a temática "saúde e meio ambiente", 
os autores alcançaram resultados por eles esperados com a maioria dos estudantes, visto que os estudantes sinalizaram um maior envolvimento e interesse nas aulas de biologia a partir da abordagem proposta. Os autores apontam que, a partir do uso dessa metodologia, a significação do conteúdo tornou-se muito evidente no processo de aprendizagem.

Similarmente, na tabela 02 apresentamos uma proposta de ensino a partir do uso de situações-problema.

Tabela 02: Proposta didática pautada no ensino a partir de situações-problema para trabalhar a temática "Dengue".

\begin{tabular}{c|l}
$\begin{array}{c}\text { METODOLOGIA } \\
\text { ATIVA }\end{array}$ & \multicolumn{1}{c}{ PROPOSTA DIDÁTICA } \\
\hline $\begin{array}{c}\text { Ensino a partir de } \\
\text { situação problema } \\
\text { soas que já tiveram dengue" (Disponível em: https://saude.abril.com.br/ } \\
\text { medicina/risco-de-morte-por-covid-19-seria-menor-em-pessoas-que-ja- } \\
\text {-tiveram-dengue/), o professor: }\end{array}$ & $\begin{array}{l}\text { - Poderá construir um movimento de investigativo, em busca dos con- } \\
\text { - Poderá disponibilizar a manchete e as orientações através do google } \\
\text { classromm ou moodle; criar uma pasta no google drive com materiais } \\
\text { bibliográficos que ajudem na pesquisa dos alunos; } \\
\text { Os alunos poderão se organizar em grupos pelo whatsapp e por vídeos } \\
\text { chamada (google meet) para a realização, discussão e apresentação } \\
\text { deste trabalho. }\end{array}$ \\
\hline
\end{tabular}

Fonte: Autores

A partir dessa proposta, o estudante passa a ter um papel ativo no processo de construção e apropriação do conhecimento, uma vez que precisará ir além da simples leitura e interpretação. Isso porque será exigido dele um posicionamento a respeito do conteúdo lido, interpretado e construído.

Nesse sentido, Silva, Silva e Tonin (2014) apontam que, através de uma situação problema no ensino de química, o aluno é instigado a participar de forma ativa no processo de ensino-aprendizagem, de modo com que eles discutam em pequenos grupos possíveis soluções para a situação-problema. No texto, os autores evidenciam a importância desse tipo de metodologia, apontando que os alunos constroem os seus próprios conhecimentos, partindo de conhecimentos 
empíricos para chegar a conhecimentos científicos. Destarte, em conjunto com aulas experimentais, essas práticas despertam no aluno um interesse maior pelas aulas e melhorando a sua qualidade.

Por fim, a última proposta metodológica (Tabela 03) traz algo que, a nosso ver, talvez seja o mais desafiador e inovador de ser realizado durante as aulas: o trabalho por projetos. Assim, questionamos: como trabalhar projetos em tempos em que os encontros presenciais não são possíveis?

Tabela 03: Propostas didáticas pautada no ensino a partir de projetos para trabalhar a temática "Dengue".

\begin{tabular}{|c|c|}
\hline $\begin{array}{r}\text { METODOL } \\
\text { ATIV }\end{array}$ & PROPOSTA DIDÁTICA \\
\hline $\begin{array}{l}\text { Ensino a partir de } \\
\text { projetos }\end{array}$ & $\begin{array}{l}\text { Usando a temática como "Com as mídias contra a dengue", o professor } \\
\text { poderá movimentar uma turma ou várias, um nível de ensino ou a escola } \\
\text { toda. Definido o público, é preciso pensar e organizar seguindo alguns } \\
\text { passos fundamentais para a construção o conhecimento a partir de pro- } \\
\text { jetos: } \\
\text { - Tornar o estudante como coparticipante; } \\
\text { - Levantar problemas e buscar sugestões de respostas; } \\
\text { - Definir os objetivos do projeto; } \\
\text { - Determinar o período de execução; } \\
\text { - Acompanhar os resultados; } \\
\text { - Refletir e analisar o produto final; } \\
\text { O professor poderá disponibilizar as orientações para realização deste } \\
\text { projeto através do google classroom ou moodle; poderá criar uma pasta } \\
\text { no google drive com materiais bibliográficos destinados aos alunos; } \\
\text { Por sua vez, os alunos poderão se organizar e se comunicar através } \\
\text { do whatsapp, facebook ou instagram; poderão realizar vídeos chamadas } \\
\text { pelo google meet para a apresentação dos projetos; poderão gravar ví- } \\
\text { deos, apresentar em forma de slides e usar ferramentas como youtube, } \\
\text { instagram, tik tok, entre outras mídias digitais. }\end{array}$ \\
\hline
\end{tabular}

Fonte: Autores 
Com base no que foi exposto na proposição de atividades da tabela 3, percebe-se que o ensino baseado em projetos demanda organização por parte do docente e dos estudantes. Assim, é preciso que ele seja planejado com muita antecedência e atenção, levando em consideração e definindo muito bem os objetivos de aprendizagem a serem alcançados.

O trabalho realizado por Matos (2009) é um exemplo de como a metodologia baseada em projetos funciona bem. Ela rompe com a monotonia que muitas vezes predomina o ambiente da sala de aula, fornecendo ao professor uma autonomia de sair dos limites curriculares das escolas. Nesse contexto, os alunos tornam-se sujeitos ativos de seu próprio conhecimento, buscando por respostas, reconstruindo conceitos e, a partir dessa metodologia, gera-se uma aprendizagem significativa aos estudantes.

No estudo de Nascimento e Alencar (2020), os autores apontam que os professores que participaram de uma pesquisa com essa proposta, em geral, afirmaram o quanto a aprendizagem baseada em projetos mostra-se eficiente e necessária, principalmente no ensino de ciências e biologia, visto que são campos disciplinares que envolvem conceitos comumente considerados como muito complexos. Assim, essa metodologia, ao ser aplicada pelo docente, proporciona aos alunos a ressignificação dos conteúdos e uma ampliação dos conhecimentos, desenvolvendo habilidades e criticidade.

Tanto para o ensino presencial, quanto para o ensino remoto, a aplicação de metodologias ativas pode representar uma possibilidade interessante, uma vez que torna o processo de ensino e de aprendizagem mais dinâmico e busca desenvolver uma participação ativa dos alunos nesse processo. Ademais, as novas formas de ensinar exigem dedicação e superação dos docentes e dos discentes, sendo essencial unir esforços para que o processo de ensino continue a acontecer, e com qualidade. Desse modo, a nosso ver, a experimentação de novas metodologias favorece a colaboração, a autonomia e a criatividade de professores e alunos. 


\section{CONSIDERAÇÕES FINAIS}

Com as aulas presenciais suspensas por conta do isolamento social provocado pela pandemia da COVID-19, se fez necessário um ensino diferenciado, que atenda às especificidades do momento. Assim, a educação precisou (e continua precisando) se reinventar. Nesse sentido, neste estudo buscamos contribuir com a prática docente no ensino de ciências ao apresentarmos algumas propostas de ensino com a temática "Dengue", tendo como base o uso de metodologias ativas. Considerando os contextos expostos, essa proposição levou em conta as especificidades do ensino remoto.

As sugestões metodológicas aqui expostas são apenas indicações de possibilidades, respeitando sempre a autonomia docente em pensar, planejar e executar as suas aulas. Ademais, acreditamos que pensar e divulgar propostas didáticas em um período tão nebuloso quanto o atualmente vivenciado pode favorecer a organização de práticas docentes mais assertivas e significativas, tanto para professores como para os estudantes. Nesse sentido, apontamos para a necessidade de outras pesquisas teóricas e/ou empíricas que pensem sobre essas questões.

\section{REFERÊNCIAS}

ANTUNES-NETO, J. M. F. Sobre ensino, aprendizagem e a sociedade da Tecnologia: por que se refletir em tempo de pandemia? Revista Prospectus, São Paulo, v. 2, n. 1, p. 28-38, ago/fev. 2020.

BARBOSA, E. F.; MOURA, D. G. Metodologias ativas de aprendizagem na Educação Profissional e Tecnológica. Boletim Técnico do Senac, Rio de Janeiro, v. 39, n. 2, p. 48-67, maio/ago. 2013.

BASTOS, C. C. Metodologias ativas, 2006. Blog Educação \& Medicina. Disponível em: <http://educacaoemedicina.blogspot.com/2006/02/metodologias-ativas.html> Acesso em: 14 marc. 2021.

BRASIL. Ministério da Educação. Parâmetros Curriculares Nacionais. Ciências da Natureza e Matemática e suas tecnologias. Brasília: MEC, 2000. 
BRASIL. Ministério da Educação. Resolução n. 02 de 15 de junho de 2012. Estabelece as Diretrizes Curriculares Nacionais para a Educação Ambiental. Brasília, DF, 15 de jun. 2012. Disponível em: <http://portal.mec.gov.br/dmdocuments/ rcp002_12.pdf>. Acesso em: 10 jun. 2020.

BRASIL. Ministério da Saúde. Boletim epidemiológico. Monitoramento dos casos de arboviroses urbanas transmitidas pelo Aedes Aegypti (dengue, chikungunya e zika), Semanas Epidemiológicas 1 a 11, 2020, Brasília, v. 51, n. 12 marc. de 2020.

BRASIL. Ministério da Saúde. Combate ao mosquito. Campo Grande (MS) recebe método inovador de combate ao Aedes aegypti. Disponível em: <https:// www.gov.br/pt-br/noticias/saude-e-vigilancia-sanitaria/2020/02/campo-grande-ms-recebe-metodo-inovador-de-combate-ao-aedes-aegypti>. Acesso em: 14 marc. 2021.

BRASIL. Ministério da Saúde. Programa Nacional de Controle da Dengue. Brasília, DF, 2002.

CRUZ, P. E. de O. e. Ebook: Metodologias ativas para a educação corporativa. Salvador: Prospecta, 2018. Disponível em: <https://docplayer.com.br/ 182887633-Ebook-metodologias-ativas-para-a-educacao-corporativa-prof-paulo-emilio-de-o-e-cruz.html>. Acesso em: 14 de marc. 2021.

ELIAS, M. A., \& RICO, V. Ensino de biologia a partir da metodologia de estudo de caso. Revista Thema, Rio Grande do Sul, v. 17 n. 2, p. 392-406, nov/abr. 2020.

FREIRE, P. Pedagogia da autonomia: saberes necessários à prática educativa. 25. ed. São Paulo: Paz e Terra, 1996.

FREIRE, P. Política e educação. 5 ed. São Paulo: Cortez, 1993. v. 23.

HUNG, W.; JONASSEN, D. H.; LIU, R. Problem-Based Learning (2008). In J.M. Spector, J. G. van Merrienboer, M.D., Merrill, \& M. Driscoll (Eds.), Handbook of research on educational communications and technology. Nova York: Routlege v. 3, p. 485-506, 2007.

MATOS, M. A. E. de. A metodologia de projetos, a aprendizagem significativa e a 
educação ambiental na escola. Ensino, Saude e Ambiente, v. 2, n. 1, p. 22-29, 2009.

MORAN, J. Metodologias ativas para uma aprendizagem mais profunda. In: BACICH, L. MORAN, J. (Orgs.). Porto Alegre: Penso, 2018.

MOREIRA, L. C; SOUZA, G. S. de. O uso de atividades investigativas como estratégia metodológica no ensino de microbiologia: um relato de experiência com estudantes do ensino médio. Experiências em Ensino de Ciências, v.11, n.3, p.1-5, 2016.

NASCIMENTO, E. O. do; ALENCAR, N. L. M. Projetos de aprendizagem como metodologia ativa no ensino de biologia. Avaliação: Processos e Políticas, v. 3. Campina Grande: Realize Editora, 2020. p. 1602-1617. Disponível em: <https://editorarealize.com.br/editora/ebooks/conedu/2019/ebook3/PROPOSTA_ EV127_MD4_ID7917_01102019142147.pdf>. Acesso em 23 de marc. 2021.

SÁ. L. P.; QUEIROZ. S. L. Estudo de caso no ensino de química. Campinas, SP: Editora Átomo, 2009. Disponível em: <http://qnesc.sbq.org.br/online/qnesc31_4/12-resenha.pdf>. Acesso em: 23 de marc. 2021.

SENAC. Metodologias ativas de aprendizagem. Rio de Janeiro: Senac, Departamento Nacional, 2018.

SILVA, T. N.; SILVA, A. C. R; TONIN, L. T. D. Investigação criminal: uma proposta de situação-problema para o ensino de química. In: SEMINÁRIO ESTADUAL PIBID DO PARANÁ, n. 2, 2014. Foz do Iguaçu. Anais eletrônicos... Foz do Iguaçu: Unioeste; Unila, 2014. p. 1402-1406. Disponível em: <https://dspace.unila.edu. $\mathrm{br} / \mathrm{bitstream} / \mathrm{handle} / 123456789 / 2874 / \mathrm{PIBID} 1 \% 2 \mathrm{c} 1403-1407$. pdf?sequence=1\&isAllowed=y>. Acesso em: 23 marc. 2021.

SOUZA, P. de. Análise de discurso. Florianópolis: LLV/CCE/UFSC, 2014.

TAN, O. S. Problem-based learning innovation: Using problems to power learning in the 21st century. Singapore: Thomson Learning, 2003.

TEIXEIRA, M. G.; BARRETO, M. L.; GUERRA, Z. Epidemiologia e medidas de prevenção do Dengue. Informe Epidemiológico do SUS, v. 8, n. 4, p. 6, out/ 
dez 1999. Disponível em: <http://scielo.iec.gov.br/pdf/iesus/v8n4/v8n4a02.pdf>. Acesso em: 25 mar. 2021.

TIMERMAN, A.; NUNES, E.; LUZ, K. Dengue no Brasil: doença urbana. 1. ed. São Paulo: Limay, 2012.

UMUARAMA. Prefeitura Municipal de Umuarama. Bairro Saudável já superou 200 toneladas de materiais recolhidos. 03 de fev. 2020. Disponível em: <http:// www.umuarama.pr.gov.br/noticias/saude/bairro-saudavel-ja-superou-200-toneladas-de-materiais-recolhidos> Acesso em: 27 jun. 2020.

UMUARAMA. Prefeitura Municipal de Umuarama. Secretaria Municipal de Saúde. Vigilância ambiental. Disponível em: <http://www.umuarama.pr.gov.br/secretaria/saude> Acesso em: 27 jun. 2020. 
doi 10.48209/978-65-89949-13-3
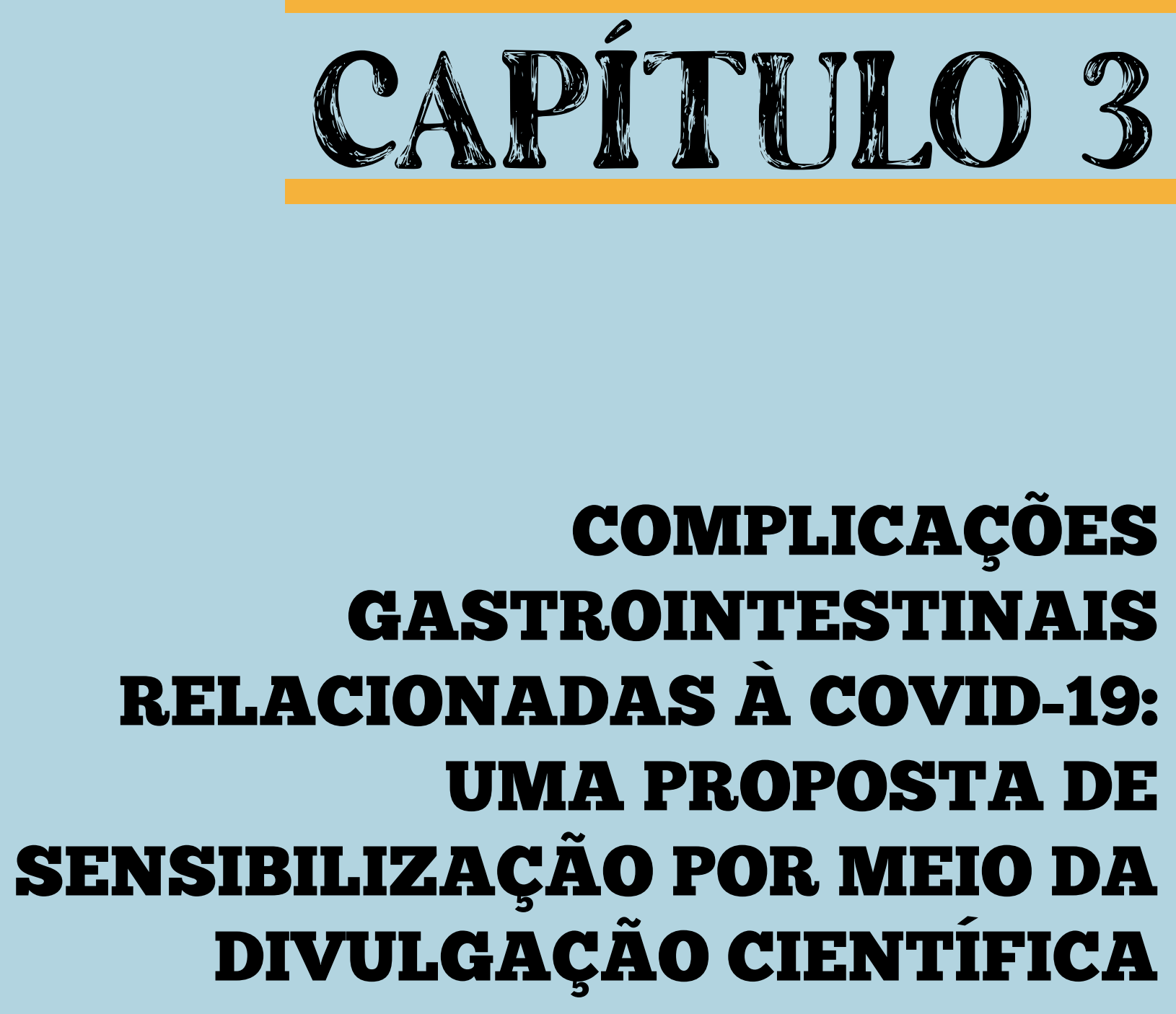

Marcelo Alberto Elias

Paula Montanhini Favetta

Wesley Alves Trindade

Flavio de Souza Júnyor Ricardo de Melo Germano 


\section{INTRODUÇÃo}

O coronavírus SARS-CoV-2 é o responsável pela doença conhecida como Covid-19. Os vírus pertencentes a família coronavírus podem causar infecções respiratórias, que, por sua vez, podem se agravar, levando o indivíduo a óbito (GU; HAN; WANG, 2020).

A doença é classificada como multissistêmica, pois pode atingir diferentes tecidos, grupos celulares e, consequentemente, diversos sistemas. Esse fator pode dificultar o diagnóstico precoce, uma vez que a sua sintomatologia pode variar muito. Os sintomas mais conhecidos popularmente desta doença são: tosse, espirro, coriza, febre, dor de garanta e dificuldades para respirar (WONG; LUI; SUNG, 2020). Porém, outros sintomas pouco conhecidos também estão vinculados à infecção e podem relacionar-se a complicações no sistema digestório.

Nesse sentido, alguns estudos recentes têm descrito as características das complicações gastrointestinais, que podem incluir dores abdominais, náuseas, diarreias e vômitos (GU; HAN; WANG, 2020, HELLER; MOTA; GRECO, 2020, WONG; LUI; SUNG, 2020). Contudo, a característica assintomática da doença talvez seja o fator de maior preocupação, pois os indivíduos infectados e assintomáticos podem transmitir o vírus para além da conhecida via respiratória. A via de transmissão orofecal, por exemplo, apresenta características preocupantes, pois o seu alcance pode ser ampliado em virtude das condições de higiene pessoal e ainda de saneamento básico (GU; HAN; WANG, 2020).

Nesse contexto, é perceptível que o conhecimento e a informação científica que temos na atualidade são complexos e, muitas vezes, podem chegar de maneira distorcida para a população. Assim, Façanha e Alves (2017) sugerem que a popularização, através da divulgação científica, pode colaborar com cenários complexos e muitas vezes inacessíveis, transformando a informação em uma linguagem mais simples e próxima do receptor. Nessa mesma linha de pensamento, Teixeira (2018) afirma que existe uma necessidade de transformação da transmissão de conhecimento que se apresenta em moldes tradicionais para uma abordagem mais próxima da realidade do ouvinte. Segundo o autor, a forma de abordagem influencia diretamente na percepção desses indivíduos.

Shigunov et al. (2020) demostraram em sua pesquisa que a popularização científica tem a capacidade de modificar imagens distorcidas e conhecimentos 
incompletos a respeito da Ciência, solidificando, assim, no ambiente popular, um conhecimento real, fundamentado em conceitos verdadeiramente científicos.

Entretanto, para além da divulgação científica, é preciso avançar na alfabetização científica. Sasseron e Carvalho (2011) destacam a alfabetização científica como um processo fundamental para a formação de cidadãos críticos e reflexivos. As autoras reforçam as três extensões da alfabetização científica: a Cultural (que se relaciona com as construções sociais); a Funcional (que se apresenta como um nível de entendimento por parte das pessoas e possibilita uma maior comunicação e produção de significados científicos); e a Verdadeira (onde a compreensão sobre ciência é mais profunda e passa pela natureza da ciência). Porém, a alfabetização científica deve ser um processo de construção integrado à formação, e que, muitas vezes, está associado ao ensino de ciências no âmbito escolar (SASSERON; CARVALHO, 2011).

Diante disso, o presente trabalho busca apesentar, por meio de elementos característicos da divulgação cientifica, uma proposta de sensibilização da comunidade a respeito das complicações e implicações da Covid-19 para o sistema digestório. Para alcançar tal objetivo, o trabalho foi organizado a partir de uma revisão bibliográfica e, posteriormente, apresenta a elaboração de uma estratégia de popularização baseada em mensagens digitais. Com essa proposta buscamos, então, ampliar o conhecimento popular e colaborar com a prevenção e a promoção da saúde.

\section{MÉTODOS}

A presente pesquisa foi realizada no primeiro semestre de 2020, no município de Umuarama, mais especificamente no campus do Instituto Federal do Paraná (IFPR), em uma parceria do primeiro autor deste estudo com pós-graduandos do Programa de Pós-graduação em Ciência Animal, com ênfase em produtos bioativos, da Universidade Paranaense. De natureza aplicada, pois busca solução de um problema, as reflexões expostas caracterizam-se como uma pesquisa de abordagem qualitativa. Desse modo, neste estudo nos pautamos em um viés descritivo e utilizamo-nos de procedimentos técnicos de revisão bibliográfica (MINAYO et al., 2011).

Para atingir aos propósitos deste estudo inicialmente realizamos uma 
revisão bibliográfica no portal de periódicos da Capes, em busca de selecionar artigos que possuíssem informações científicas a respeito da relação entre a infecção causada pela Covid-19 e o sistema digestório. Para as buscas utilizamos como palavra-chave o termo "Covid-19". A partir desse levantamento, iniciou-se o processo de seleção das informações a serem popularizadas em nossa proposta de ensino, tendo como critério para a composição de nosso corpus a escolha de artigos que abordassem a relação entre a Covid-19 e o sistema digestório, bem como que trouxessem em suas reflexões uma relação direta com o cotidiano da população. Ou seja, optamos por selecionar as pesquisas que tratavam especificamente sobre as formas de infecção, os sinais/sintomas e as possíveis formas de prevenção à doença. Optou-se ainda por escolher ao menos um artigo elaborado por autores brasileiros, buscando assim valorizar as pesquisas científicas produzidas em território nacional.

Destarte, foi elaborada uma sequência metodológica, descrita a seguir (figura 1), com o intuito de apresentar uma proposta de ensino.

Figura 1- Sequência metodológica da pesquisa

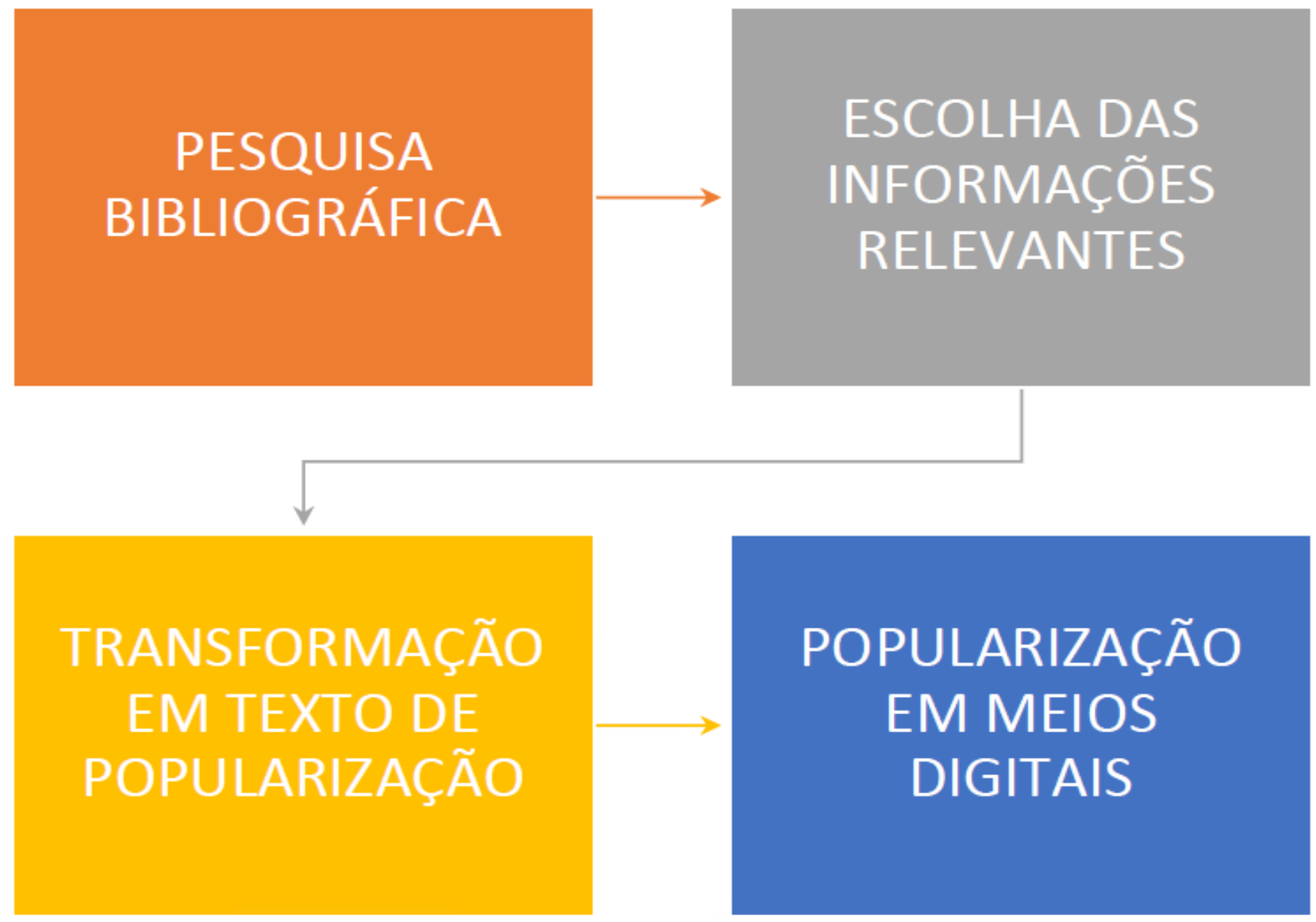

Fonte: Elaborado pelos autores. 
As informações científicas encontradas a partir das buscas bibliográficas foram transformadas em textos de divulgação científica intencionando a popularização de questões relacionadas ao tema de interesse. Essa transposição didática ${ }^{1}$ foi feita com o intuito de que essas discussões fossem disponibilizados de maneira digital, por meio do aplicativo WhatsApp, mais especificamente na página institucional oficial e por e-mail.

\section{RESULTADOS E DISCUSSÃO}

A partir da revisão bibliográfica realizada no portal de periódicos da Capes foi possível destacar informações sobre a relação entre os males causados à saúde pela Covid-19 e o sistema digestório. Para cada uma delas foram elaboradas mensagens de popularização, conforme mostra a Tabela 1.

Tabela 1 - Resultado da revisão bibliográfica e sua respectiva transformação em mensagem de popularização.

\section{INFORMAÇÃO CIENTÍFICA}

Pesquisas recentes apontam que a infecção pelo vírus apresenta sintomas gastrointestinais, como, por exemplo, vômitos, diarreias e danos em órgãos e tecidos do sistema digestório (GU; HAN; WANG, 2020, HELLER; MOTA; GRECO, 2020, WONG; LUI; SUNG, 2020).

\section{MENSAGEM DE POPULARIZAÇÃO}

Fique atento... Diarreia e vômitos também podem ser sintomas da infecção por coronavírus.

Dor abdominal? Em caso de persistência procure um médico, pois a Covid-19 também pode provocar esse tipo de dores.

Já lavou as mãos? Não esqueça de lavar sempre as mãos, pois é possível a transmissão do vírus pela via fecal-oral.

Frutas e verduras!!! São fundamentais para a nossa saúde. Porém, não esqueça de lavá-las bem. A Covid-19 não é brincadeira e pode nos infectar através de alimentos contaminados e não lavados.

Cuidados na separação do lixo doméstico são essenciais para evitar a contaminação dos trabalhadores envolvidos na reciclagem e na coleta do lixo. Isole bem o lixo proveniente dos banheiros... O VíRUS PODE ESTAR AI.

Fonte: Elaborado pelos autores.

1 Aqui não nos referimos ao termo utilizado no âmbito da Didática das Ciências, visto que o utilizamos em seu sentido literal. 
As cinco mensagens de popularização, apresentadas na tabela 1, foram disponibilizadas semanalmente por meio das mídias digitais presentes na instituição de ensino, tais como: página oficial, redes sociais do Instituto, e-mail e WhatsApp. Nos e-mails e no WhatsApp, as mensagens foram disponibilizadas via grupos já existentes das turmas.

Destacamos que a presente proposta buscou apenas a elaboração/proposição de atividades de divulgação das questões científicas sobre o tema de interesse, os efeitos de sentido produzidos pela mesma, serão analisados em uma nova fase. Tal fase fará parte de uma nova etapa a ser realizada após aprovação do comitê de ética em pesquisas com seres humanos. Contudo, acreditamos nas contribuições dessa proposta como estratégia a ser replicada e aprimorada de acordo com a realidade de cada instituição.

Na tabela 1 podemos observar que existem essencialmente duas informações científicas relevantes a respeito das complicações e da relação do vírus com o sistema digestório: uma sobre os sintomas e a outra sobre as formas de infecção. Essas informações estão vinculadas à forma de infecção fecal-oral (resíduos de fezes entrando pela via oral) e à característica multissistêmica da doença. Assim, as pesquisas apresentadas e transpostas didaticamente envolvem desde estudos clínicos, até estudos moleculares (GU; HAN; WANG, 2020, HELLER; MOTA; GRECO, 2020, WONG; LUI; SUNG, 2020).

Entre os estudos que consideramos que poderiam trazer informações relevantes à população em meio ao quadro pandêmico que vivenciamos, destacamos o estudo de Gu, Han e Wang (2020). Os autores apontam em seu estudo algumas possíveis implicações do vírus em relação ao sistema digestório. Essas implicações envolvem questões como: alterações em grupos celulares responsáveis por secreção; alteração do tecido epitelial de revestimento do tubo digestório; e comprometimento no funcionamento dos órgãos deste sistema. Porém, considerando as características textuais do gênero artigo científico, a nosso ver, essas informações, que envolvem métodos moleculares de pesquisa, tornam o artigo de complexa compreensão, inviabilizando a sua divulgação para comunidade tal como está. 
Nesse sentido, concordamos com Façanha e Alves (2017), quando destacam a importância de transformar a informação restrita à comunidade científica em um texto popular, com capacidade de alcance de sujeitos com diferentes realidades culturais e intelectuais. Os autores ainda afirmam que tal processo corrobora com a alfabetização científica e com a formação de cidadãos críticos e reflexivos. Na mesma linha de pensamento, Sasseron e Carvalho (2011) corroboram essa afirmação ao trazerem a importância de um entendimento maior e mais profundo sobre as características e as extensões da alfabetização científica para a formação social. Em seu estudo, as autoras destacam a importância de propostas didáticas que promovam e estimulem o desenvolvimento da alfabetização científica.

Com isso, é possível verificar que, a partir da seleção, adaptação e circulação de mensagens de popularização do conhecimento científico propostas neste trabalho, a informação se tornou, na visão dos autores, menos complexa e mais objetiva, visto que essas mensagens foram construídas a partir de textos curtos, claros e diretos. Almeida et al. (2019) demonstram em seu trabalho que dessa maneira é possível dialogar com a comunidade e aproximá-la da ciência. Os autores indicam a extensão universitária como um meio eficiente para a realização de tais ações. Destarte, a presente proposta também poderia ser empregada em ações de extensão, uma vez que a sua aplicação extrapola os limites da instituição de ensino.

Atualmente, o Campus de Umuarama do IFPR conta com cerca de mil estudantes, entre a educação técnica integrada ao ensino médio, os cursos técnicos e os cursos superiores. Assim, neste âmbito, podemos compreender que a utilização de meios de divulgação da ciência, como, por exemplo, através do uso de mídias digitais, pode ampliar o alcance da informação que se deseja que seja popularizada, atingindo assim familiares, amigos e a comunidade envolvida com a instituição.

Shigunov et al. (2020) apontaram em seu trabalho que a internet se apresenta como o melhor meio de divulgação. Em contrapartida, para os autores, os artigos científicos são apontados como os que menos são indicados para tal finalidade. Porém, esses autores não descartam a importância dos artigos científicos, pois estes são usados como base para a construção de textos de 
popularização. Tal entendimento também foi demonstrado na presente proposta, conforme apresentamos na Tabela 1. Isso porque, embora o objetivo da construção desta tabela tenha sido a divulgação das mensagens de popularização da Ciência, a fonte dessas mensagens foram os artigos científicos supracitados.

Ainda nessa mesma linha de raciocínio, Motta-Roth e Scherer (2016) afirmam que a popularização da ciência e o artigo científico compõe um mesmo gênero, que é responsável por tornar público o discurso da ciência. Dessa maneira, fica evidente que o texto popular, fundamentado em um artigo científico, não tira o seu mérito, pelo contrário, ele aproxima a(s) ciência(s) das diferentes realidades da população. Ademais, isso pode levar com que se quebre o tabu existente ainda entre pesquisadores que se opõe à popularização do conhecimento, julgando-a como um processo de vulgarização da informação.

Desse modo, pensando na promoção da saúde por meio da divulgação científica, principalmente no que envolve a Covid-19 e as suas implicações para o sistema digestório, realizamos, no âmbito de uma instituição pública de ensino, aquilo que para nós representa um canal de comunicação e de confiança com/da comunidade interna e externa. Assim, julgamos ter potencializado através dessa relação uma maior sensibilização em busca do controle e da redução da pandemia (ALMEIDA et al., 2019).

Contudo, em tempos de tantas informações distorcidas ou falsas, muitas vezes disponibilizadas na mídia, Montalvão Neto et al. (2020) reforçam a importância de se combater e buscar estratégias que identifiquem tais informações. Nesse sentido, vale lembrar que toda a construção didática proposta nesse trabalho foi embasada em informações científicas provenientes de artigos, oriundos de base de dados confiáveis, não baseando-se, portanto, em fontes de senso comum.

\section{CONSIDERAÇÕES FINAIS}

Neste estudo buscamos colaborar com a sensibilização e, consequentemente, com a redução do avanço da pandemia através da divulgação e da popularização da ciência. Diante do relato e da proposta expostos, fica evidente o papel dos formadores de opinião em meio a esse processo complexo e dinâmico 
de informações veiculadas à comunidade. Assim, consideramos que conceitos e resultados de pesquisas científicas, que atingem diretamente a população, precisam ser constantemente ressignificados e transformados em formas de linguagem mais claras e acessíveis, buscando assim a promoção da saúde e o bem-estar social.

Com base em nossas discussões, sugerimos ainda que as mídias digitais utilizadas em tempos em que a presencialidade está comprometida, podem potencializar e colaborar ativamente com a educação em espaços não formais. Para o ensino de ciências, em especial, pontuamos que a construção de conhecimentos a partir de fontes científicas e que promovam a reflexão pode colaborar com a formação de indivíduos mais críticos e reflexivos em suas formas de olhar para a ciência e para as suas relações cotidianas/pessoais com a sociedade.

Por fim, esperamos que, a partir dessa proposta, possamos colaborar com as reflexões sobre a prática e as propostas didáticas que envolvam a alfabetização científica, a divulgação científica e o ensino de ciências como um todo, em espaços formais e não formais e em diferentes níveis de ensino, com especial ênfase às especificidades em tempos de pandemia.

\section{REFERÊNCIAS}

ALMEIDA, A. P. M. S. et al. Popularização da Ciência e Tecnologia: Uma Experiência da UEFS. Caderno de Física, v.17, n. 2, p.25011-25018. 2019.

FAÇANHA, A. A. B.; ALVES, F. C. Popularização das Ciências e Jornalismo Científico: possibilidades de Alfabetização Científica. Amazônia - Revista de Educação em Ciências e Matemática, v.13, n.26, p.41-55. Jan-Jun. 2017.

GU, J.; HAN, B.; WANG, J. Covid-19: Gastrointestinal manifestations and potential fecal-oral transmission. Gastroenterology, v.158, p.1518-1519, 2020.

HELLER, L.; MOTA, C.; GRECO, D. Covid-19 faecal-oral transmission: Are we asking the right questions? Sciense of The Total Evironment, v.729, p. 1-3, 2020.

MINAYO, M. C. S.; DESLANDES, S. F.; GOMES, R. Pesquisa social: teoria, método e criatividade. Editora Vozes Limitada, 2011. 
MONTALVÃO NETO, A. L. et al. Ciência, fake news e pós-verdades: a produção de efeitos de verdade em tempos de pandemia. In: Encontro Virtual de Documentação em Software Livre e Congresso Internacional de Linguagem e Tecnologia Online. Anais eletrônicos... On-line, 2020. p. 1 - 8. Disponível em: https://www.academia.edu/44560984/CI\%C3\%8ANCIA_FAKE_NEWS_E_P\%C3\%93S_VERDADES_A_PRODU\%C3\%87\%C3\%830_DE_EFEITOS_DE_ VERDADE_EM_TEMPOS_DE_PANDEMIA. Acesso em: 04 jul. 2021.

MOTTA-ROTH, D.; SCHERER, A. S. Popularização da ciência: a interdiscursividade entre ciência, pedagogia e jornalismo. Bakhtiniana: Revista de Estudos do Discurso, v. 11, p. 164-189, 2016.

SASSERON, L. H.; CARVALHO, A. M. P. Alfabetização científica: uma revisão bibliográfica. Investigações em ensino de ciências, v. 16, n. 1, p. 59-77, 2016.

SHIGUNOV, P. et al. Percepção pública sobre a ciência em um evento sobre popularização da ciência em curitiba: paraná. Itinerarius Reflectionis, v. 16, n. 2, p. 01-10, 2020.

TEIXEIRA, L. H. O. A abordagem tradicional de ensino e suas repercussões sob a percepção de um aluno. Revista Educação em Foco, n. 10, p. 93-103, 2018.

WONG, S. H.; LUI, R. N. S.; SUNG, J. J. Y. Covid-19 and the digestive system. Journal of gastroenterology and hepatology, v. 35, n. 5, p. 744-748, 2020. 
do $10.48209 / 978-65-89949-13-4$

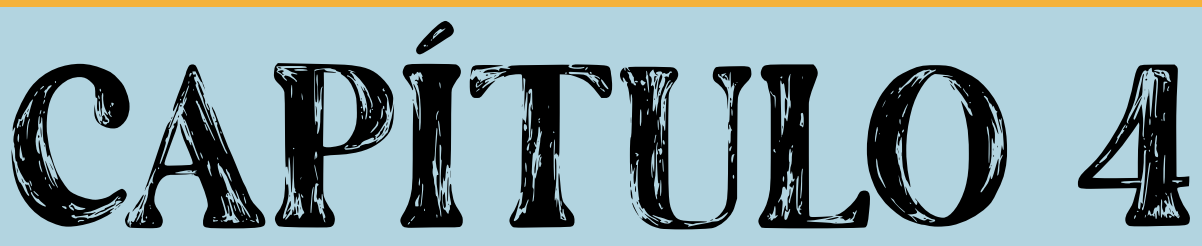

\section{A UTILIZAÇÃO DE AMBIENTES VIRTUAIS DE APRENDIZAGEM NO ENSINO DE ANATOMIA HUMANA}

Lilia Cavicchioli Fonseca latecola Rita de Cássia Frenedozo 


\section{INTRODUÇÃo}

Segundo a Organização das Nações Unidas para a Educação, a Ciência e a Cultura (Unesco), milhões de estudantes estão sem aulas por causa do fechamento total ou parcial de escolas e universidades em mais de 150 países, devido à pandemia do coronavírus. No Brasil, por determinação do Ministério da Educação (MEC), as aulas presenciais estão suspensas por tempo indeterminado em todo o território nacional (BRASIL, 2020). Desse modo, as instituições de ensino estão autorizadas a realizar "atividades letivas que utilizem recursos educacionais digitais, tecnologias de informação e comunicação ou outros meios convencionais" (BRASIL, 2020), também denominadas 'ensino remoto'.

Entre os estabelecimentos que adotaram essa orientação, estão as escolas da rede particular de ensino, na qual seus respectivos professores passaram a trabalhar em tempo integral na própria casa, em situação de trabalho remoto, home office ou tele trabalho, expostos às condições de trabalho improvisadas e às jornadas extenuantes. Segundo dados da Unesco (Organização das Nações Unidas para a Educação, a Ciência e a Cultura) mais de 1,3 bilhões de alunos de todo o mundo estão sendo afetados pelo fechamento das escolas e universidades devido ao isolamento social necessário para combater a pandemia.

Esse número representa cerca de $80 \%$ da população estudantil mundial. Paralelo a isso mais de 60 milhões de docentes também deixaram de trabalhar presencialmente em salas de aula, criando assim um novo cenário mundial para a educação. Esse novo mundo criou um desafio inédito para as universidades, como manter a relação aluno/professor em tempos de pandemia? Dessa forma novas estratégias estão sendo pensadas e aplicadas, inovando a forma de ensinar através de metodologias virtuais (ARRUDA, 2020; BUENO; BUENO, 2020).

A oportunidade singular de analisar o processo ensino aprendizagem da ciência Anatomia Humana nos cursos da área da Saúde que tradicionalmente tem sido realizado presencial em laboratórios. Alguns estudos têm se posicionado de forma receptiva às transformações e às avaliações que contribuem para o aprimoramento metodológico de ensino da Anatomia Humana mesmo antes da 
pandemia (CAHILL et al., 1997; FORNAZIERO et al., 2003) e no atual cenário pandêmico da educação (CRUZ, 2020; DE MEDEIROS et al. 2020; SOUZA et al. 2020).

Entretanto qualquer mudança gera sempre grandes desafios, mudanças repentinas ainda mais, aliadas a falta de uma regulamentação apropriada para esse modelo virtual acabam gerando muitas incertezas nesse período tão distinto. Essa nova realidade que a educação passa nesse momento de pandemia vem acompanhada de uma certa rejeição e/ou dificuldade tanto para os alunos quanto dos professores. Treinamento com os docentes para que possam ter entendimento dessas novas ferramentas de ensino, estão sendo fundamentais para o desenvolvimento dessas novas competências e habilidades, proporcionado novas ações até então impensáveis no contexto da sala de aula presencial.

A disciplina de anatomia não foge dessa realidade, sua evolução ao longo da história se fez presente e de forma marcante, no que diz respeito até na evolução da área médica. No início era na curiosidade que se aprendia anatomia, estudando nos cadáveres oriundos muitas vezes dos soldados durante as guerras. Hoje a tecnologia tornou-se uma importante aliada para o desenvolvimento do ensino e por consequência da aprendizagem dessa disciplina.

Estruturas como mesas digitais, aplicativos para celular, atlas digital e laboratórios virtuais proporcionam experiências até então impensáveis em uma aula de anatomia, restrita antigamente aos laboratórios com peças imersas no formol (LIMA, 2018). Com o advento da pandemia essas novas tecnologias se tornaram ainda mais importantes e de uma hora para outra, indispensáveis para o aprendizado à distância.

Com todas essas alternativas surge a necessidade de se avaliar o entendimento do aluno frente ao uso dessas novas tecnologias em disciplinas que historicamente não apresentavam mudanças significativas no processo ensino-aprendizagem mesmo com avanços tecnológicos disponíveis e métodos didáticos mais evoluídos, como é o caso do ensino de Anatomia Humana. No relacionamento professor-aluno, considerado longo e complexo, os sujeitos se influenciam reciprocamente em sala de aula, e os resultados do ensino e da aprendizagem de- 
penderão das muitas possibilidades de diretrizes desses relacionamentos. Como fica os resultados diante de uma oferta utilizando-se ambientes virtuais? Os alunos se adaptam às estratégias de ensino remoto?

Como consequência da impossibilidade de usar os recursos tradicionais no ensino da Anatomia Humana esta pesquisa teve como objetivo avaliar as percepções dos acadêmicos do curso de Fisioterapia sobre o processo de aprender utilizando-se o Ensino Remoto Síncrono Emergencial (ERSE).

\section{PROCEDIMENTOS METODOLÓGICOS}

A modalidade de pesquisa utilizada nesse estudo foi do tipo quanti-qualitativa. A pesquisa quantitativa é um método de pesquisa social que utiliza a quantificação nas modalidades de coleta de informações e no seu tratamento, mediante técnicas estatísticas, tais como percentual, média, desvio-padrão, coeficiente de correlação, análise de regressão, entre outros, já uma pesquisa qualitativa vai além de compreender e interpretar comportamentos e tendências, o instrumento também é usado para identificar hipóteses para um problema e descobrir as percepções e expectativas dos participantes voluntários (DA SILVA, 2018).

\subsection{Local de estudo e sujeitos da Pesquisa}

Este trabalho foi realizado durante a disciplina de Anatomia do Curso de Fisioterapia do Centro Universitário nossa Senhora do Patrocínio - CEUNSP, localizada no município de Itu - SP, que ocorre no $2^{\circ}$ semestre e tem como carga horária 60h, sendo 03 aulas semanais e corresponde ao conteúdo da Anatomia Humana do Aparelho Locomotor.

A amostra para esta pesquisa foi de 60 alunos do curso de Fisioterapia do $2^{\circ}$ semestre, sendo composto por 40 mulheres e 20 homens com média de idade de 19 anos que aceitaram participar de forma voluntária desse estudo. As atividades propostas foram administradas e acompanhadas pelo professor pesquisador. Durante a intervenção não foram coletadas informações que pudessem causar qualquer tipo de constrangimento ao aluno. Essa pesquisa foi submetida 
ao Comitê de Ética em Pesquisa em Seres Humanos da Universidade Cruzeiro do Sul e aprovada conforme o protocolo 4.426.591.

Os riscos inerentes a esse estudo se restringiram apenas às dificuldades de conexão durante as aulas, não havendo quaisquer outros. Os benefícios que esse estudo proporcionou está diretamente ligado ao aprimoramento do uso das ferramentas digitais e as vantagens da utilização desses recursos no ensino e aprendizagem.

\subsection{Sequência didática e aplicação de questionário}

As aulas de anatomia ocorreram conforme calendário acadêmico, sendo uma vez por semana com duração de 03h/aulas. A professora disponibiliza o link com antecedência aos alunos que utilizam a plataforma Blackboard para assistir as aulas que são realizada de forma síncrona através de compartilhamento de tela (professor) utilizando-se de slides (power point) e o laboratório virtual, aonde os alunos conseguem interagir no formato virtual no mesmo ambiente virtual de aprendizagem. O cronograma de aulas foi seguido conforme o plano de ensino da disciplina.

\subsection{Apresentação da proposta aos alunos}

Nessa etapa seguindo o cronograma de aulas e nesse recorte do semestre os objetivos foram reconhecer e compreender os constituintes do aparelho locomotor para fundamentar o raciocínio e aprendizado da anatomia do sistema esquelético, articular e muscular. Adquirir habilidades quanto à identificação das estruturas anatômicas, capacidade de interpretação do conteúdo teórico relacionando com a prática, compreender a relação entre as estruturas anatômicas e associar com prática clínica.

No caso da turma do $2^{\circ}$ semestre do curso de fisioterapia na disciplina de anatomia do aparelho locomotor, iniciamos o estudo com o sistema esquelético, nesse momento os alunos estudaram seguindo essa ordem: definição dos ossos, classificação dos ossos, constituição dos ossos, acidentes ósseos, nomes dos ossos e divisão do esqueleto. 
Após a realização dos 06 encontros os alunos responderam o questionário semiestruturado no Google Forms ${ }^{1}$ para verificar o grau de satisfação dos alunos em relação às atividades propostas e principalmente a contribuição da aula remota para o estudo da anatomia.

Após aplicação do questionário as respostas foram analisadas para determinar a contribuição que essa didática utilizando tecnologia digital no processo ensino e aprendizagem proporcionaram em relação ao modelo tradicional de ensino por meio da análise e comparativo das respostas do questionário aplicado e avaliando o grau de satisfação dos alunos em relação às atividades propostas.

Os dados foram avaliados estatisticamente através do software da Microsoft Excel, para poder ser geradas as porcentagens relativas a cada item proposto no questionário e através desses dados percentuais, foram gerados os gráficos apresentados nessa pesquisa, avaliando os benefícios que esse estudo pode proporcionar está diretamente ligado ao aprimoramento do uso das ferramentas digitais e as vantagens da utilização desses recursos no ensino e aprendizagem.

\section{RESULTADOS E DISCUSSÃO}

\subsection{Análise do ERSE}

A princípio mapear com quais recursos os alunos tinham à disposição para poder assistir as aulas remotas, assim podemos entender com quais ferramentas tecnológicas o docente pode dispensar em suas aulas, como texto, vídeos, aplicativos e etc. Dos 60 alunos matriculados na disciplina de anatomia 52 responderam o questionário representando $86,6 \%$ do total de matriculados. Quanto aos recursos utilizados para assistir as aulas 40 alunos $(76,9 \%)$ utilizaram notebook, 12 alunos $(23,1 \%)$ utilizaram PC e 46 alunos (88,5\%) utilizaram o celular para terrem acesso aos conteúdos, conforme mostra a figura número 1.

1 Pode ser visualizado em: https://forms.gle/TtDnPtwcVRjRSH6u8. Acesso em 22 de jul. 2021. 
O ENSINO DE CIÊNCIAS NO BRASIL DURANTE E APÓS A PANDEMIA DA COVID-19: PERSPECTIVAS, DESAFIOS E POSSIBILIDADES

Figura 1. Resultados do uso de recursos para assistir as aulas

Nas questões 1 e 2 selecione as alternativas que correspondam a sua realidade:( Você pode escolher mais de uma resposta)

1.Quais equipamentos você utiliza para acessar a internet?

52 respostas

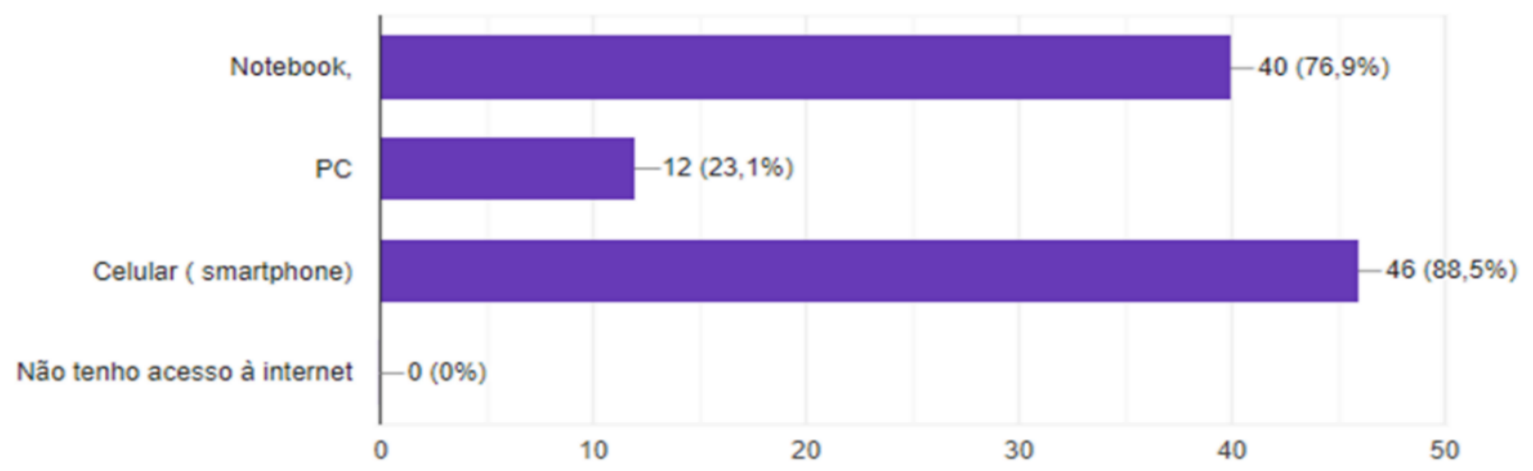

Fonte: Autoria própria.

Se analisarmos os dados acima, a preferência foi para as tecnologias mobile (smartphone e notebook), lembrando que os alunos podiam assinalar mais de uma alternativa/recurso. Dados semelhantes foram encontrados Berwanger (2020) aonde foram avaliados sujeitos que atuam no ambiente escolar, destacando-se pelo uso mais intenso de dispositivos digitais móveis, como o smartphone equipamento que reúne os recursos de portabilidade, conectividade, comunicabilidade e ubiquidade, seria um dos fatores importantes na virada do século $X X$ para o XXI, capaz de mudar, de forma rápida e silenciosa, as práticas de aprendizagem e de comunicação em diversos contextos de interação social.

Não podemos esquecer também que o professor precisa ampliar a visão sobre as possibilidades do uso das tecnologias na sala de aula, além de apenas "pôr em prática" o mais importante é saber usá-las e como essas ações irão impactar na aprendizagem dos alunos (ERIKA, 2014).

Por outro lado Garcia e Rito (2020) alertam para ao uso da tecnologia por parte dos alunos nas instituições (IES), pois para que essa ferramenta atinja seus objetivos se faz necessário que o professor, como mediador, tenha condições de 
oferecer todas as condições para que isso ocorra, conduzindo todo o processo de construção dos conteúdos científicos, seguro com suas competências e habilidades, para que assim os alunos sejam beneficiados com o uso de celulares e tabletes que é um grande tabu em sala de aula e que o uso desses aparelhos sejam para o ensino e aprendizagem dos conteúdos, caso contrário a tecnologia irá prejudicar todos em sala.

Seguindo nossa pesquisa os alunos responderam quais eram as plataformas de busca que eles mais acessavam para seus estudos. Dentre as alternativas 28 alunos $(58,3 \%)$ acessam tanto site do Crefito (Conselho Regional de Fisioterapia e Terapia Ocupacional) quanto o site PEDro (base de dados em evidências em fisioterapia), 39 alunos (75\%) outras bases de dados em fisioterapia, 4 alunos (7\%) no physiotherapyexersices e apenas 1 aluno (1,9\%) não consultou nenhuma base de dados conforme mostra a figura 2, lembrando que podia assinalar mais de uma opção.

Figura 2. Resultados dos sites de busca

\section{Você costuma utilizar a internet para estudar/aprender sobre conteúdos relacionados com o curso Fisioterapia?}

52 respostas

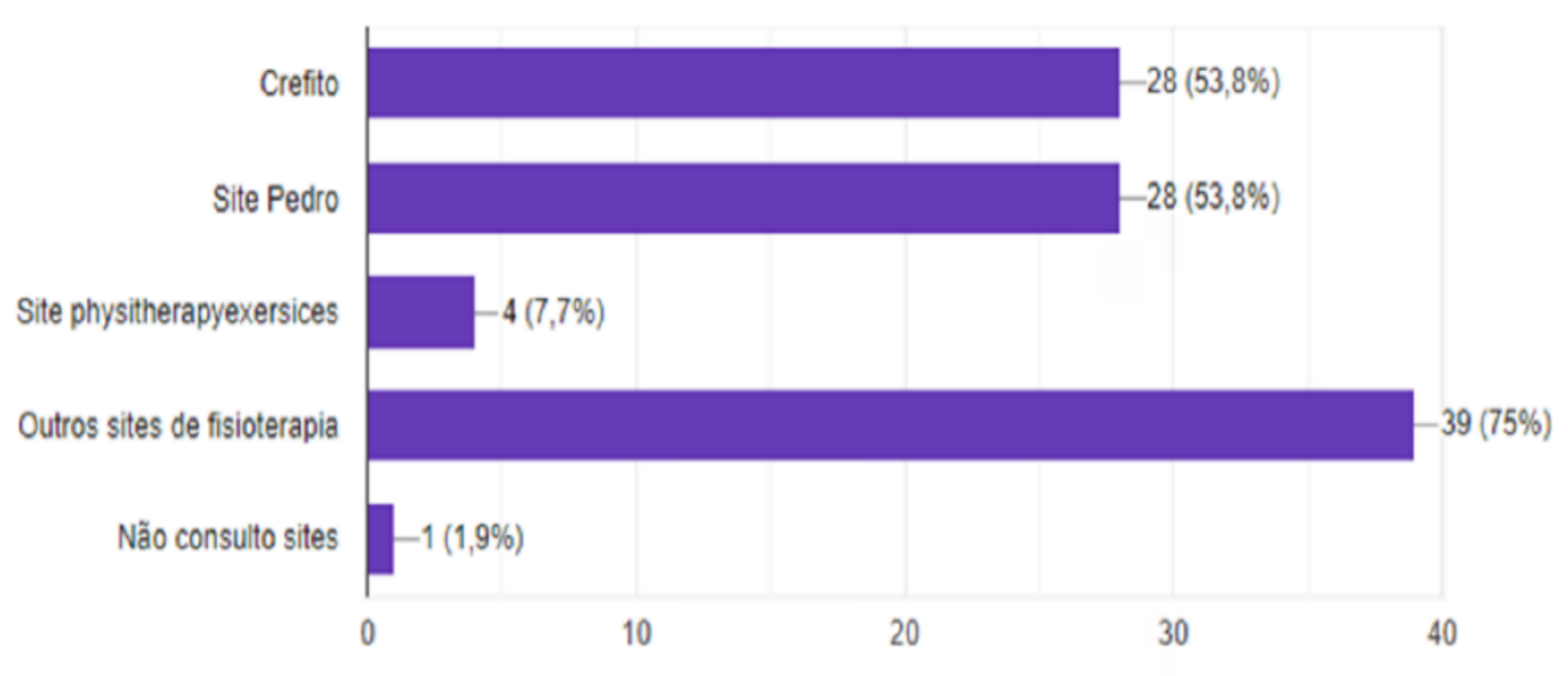

Fonte: Autoria própria. 
Segundo Bueno e Bueno (2020) a fisioterapia é uma ciência da área da saúde que "avalia, previne e reabilita os distúrbios cinéticos funcionais do corpo humano, de origem genética ou adquirida, dessa forma a disciplina de anatomia é de suma importância para o desenvolvimento do egresso." Diante desse quadro a área da educação em saúde está inserida em suas competências, pois a busca por informação é uma premissa da profissão, tornando a busca pela informação um pré-requisito para o desenvolvimento das competências e habilidades desse novo profissional. Hoje essas informações são pesquisadas através dos sites de busca disponíveis da área de estudo. Esses dados vão de encontro com a nossa pesquisa, aonde apenas $1 \%$ dos entrevistados não utilizam nenhuma base de dados para desenvolvimento de conhecimento.

Outro dado importante observado nesse resultado é a diversidade na busca pelas informações pois temos 39 alunos utilizando várias bases de dados para pesquisa, fora os mais utilizados como Crefito ou o PEDro. Mas também preocupa a origem dos dados pesquisados pois podemos ter acesso a uma gama enorme de informações inverídicas que podem induzir ao erro durante o exercício da profissão.

Além disso temos as fake news, infelizmente tão comuns atualmente, que tem por objetivo o compartilhamento de falsas informações nas redes sociais. São tidas enquanto fontes verídicas pela população, que não buscam checar a veracidade dos fatos em veículos tradicionais de informação". (DALESSANDRO, 2020). Ainda segundo o autor, as fake news são resultado da pós-verdade, caracterizada pela distopia conceitual e semântica, criando uma distorção da verdade através do apelo às emoções e à satisfação de crenças e ideologias daqueles que criam e/ou espalham as notícias falsas.

Segundo estudos da fundação Getúlio Vargas em 2017, o Brasil atingiu a marca de 1 smartphone/habitante, atingindo a marca de aproximadamente 208 milhões de aparelhos, esses dados estão de acordo com os resultados desse estudo, pois $88 \%$ dos alunos que responderam o questionário usavam o smartphone para estudar, tornando esse equipamento indispensável na prática do ensino conhecida como mobile learning (VILELA, 2018; SANTOS, 2015). 
A utilização de aplicativos móveis no ensino acelera o aprendizado e permite que ele ocorra em locais diversificados devido à facilidade de acesso (NANI, 2020). Além disso, alguns estudos demonstraram uma melhora da performance no processo educacional de alunos que utilizaram aplicativos móveis educativos (HAMDAN, 2013; ALQAHTANI, 2015).

Outra pesquisa abordou o uso da realidade virtual no campo da anatomia humana para o ensino da graduação em medicina. Desenvolveu-se um software associado a um óculo estereoscópico, aonde os alunos têm a percepção de estar dentro do ambiente virtual, estudando o sistema ósseo, em especial os ossos do crânio, além de acompanhadas por explicações em áudio. A percepção dos alunos foi que o uso da tecnologia pois possibilitou a inserção mais aprofundada no conteúdo, que contribuiu para visualização de estruturas que, muitas vezes, são difíceis de imaginar em imagens ou peças cadavéricas (BOFF, 2020).

Do total de alunos pesquisados $72 \%$ disseram estar satisfeitos ou muito satisfeitos com o uso da tecnologia, dados esses que vão de encontro com a nossa pesquisa pois se considerar os resultados apenas a partir do conceito 7 (70,6\%) tiveram uma percepção favorável ao uso do laboratório virtual (figura 3).

Figura 3. Percepção do uso do laboratório virtual

\section{Em uma escala que vai de zero a dez, sendo zero totalmente insatisfeito e dez totalmente} satisfeito, qual a sua percepção em relação ao uso do laboratório Virtual na disciplina de anatomia humana?

51 respostas

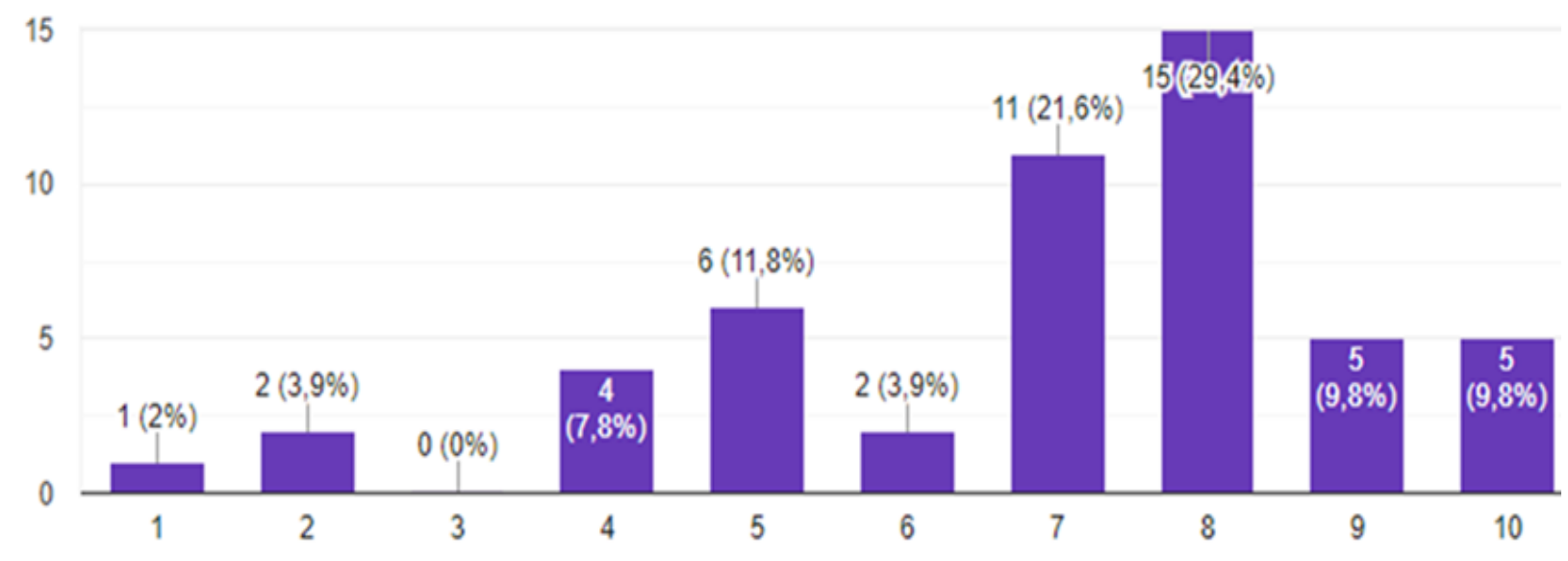

Fonte: Autoria própria. 
Mitrousias et al. (2018) comparou a eficiência de um software 3D chamado BioDigital Human antes das provas em cadáveres no laboratório, tendo como método a comparação entre dois grupos de graduação compostos por estudantes de medicina do primeiro ano sem conhecimentos anatômicos prévios. Os alunos foram submetidos a um exame com imagens cadavéricas e 3D após as aulas e as suas percepções também foram avaliadas.

Como resultados, os alunos que utilizaram as imagens 3D obtiveram meIhor desempenho nas provas, quando comparado aos alunos que estudaram apenas nas peças cadavéricas, isso pode ter relação direta com a percepção desses alunos em relação as imagens com movimento e coloridas, pois fatores que divergem do nosso cotidiano como, movimento, intensidade chamam mais a nossa atenção, do que apenas as peças cadavéricas estáticas em uma mesa, justificando assim o melhor desempenho do grupo que utilizou recursos tecnológicos.

Dados semelhantes a esse estudo obtivemos em nossa pesquisa aonde $64,7 \%$ e $70,5 \%$ dos alunos responderam de 7 para 10 quanto a percepção de terem aproveitado melhor os estudos com o uso do laboratório virtual e através das aulas no formato da ERSE respectivamente (figuras 4 e 5), como também obtendo um desempenho melhor nas avaliações realizadas nesse semestre. A motivação de utilizar recursos que possibilitam mais interatividade com o que está aprendendo também prendem mais a atenção dos alunos favorecendo o aprendizado. 
Figura 4. Percepção quanto ao aprendizado com o uso do laboratório virtual

\section{Em uma escala que vai de zero a dez, sendo zero totalmente insatisfeito e dez totalmente satisfeito, você considera que o conteúdo de anatomia foi melhor absorvido com a utilização do laboratório virtual?}

51 respostas

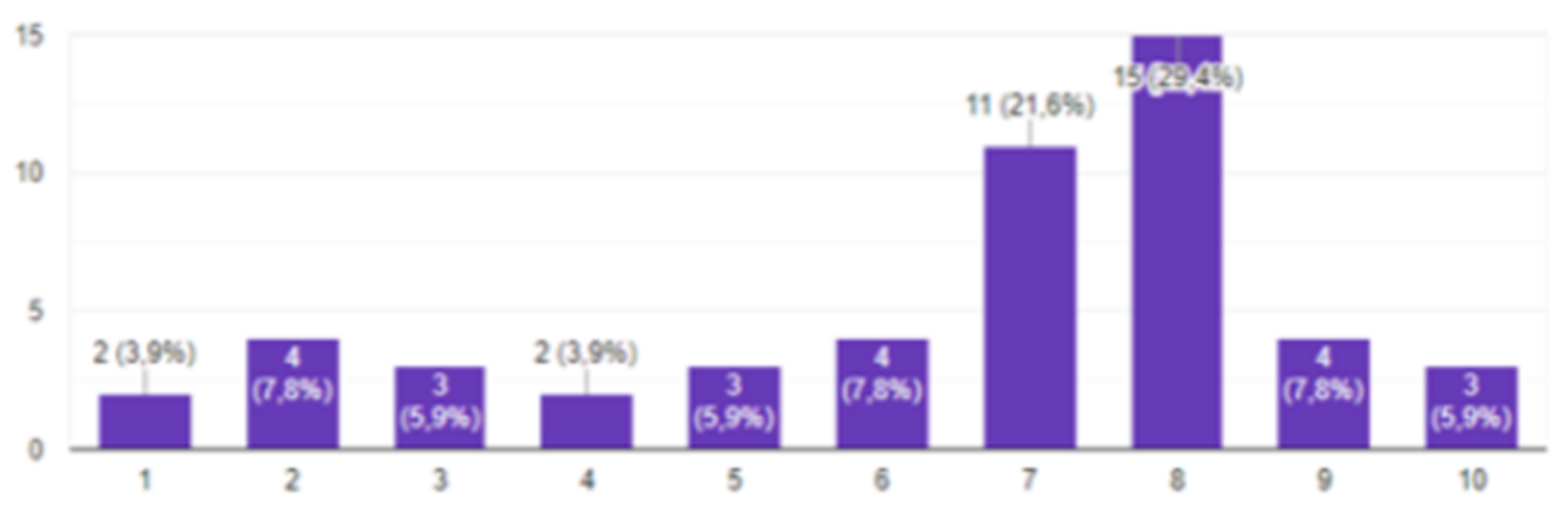

Fonte: Autoria própria.

Figura 5. Percepção quanto ao método de estudo remoto

5. Em uma escala que vai de zero a dez, sendo zero totalmente insatisfeito e dez totalmente satisfeito, qual a sua percepção quando comparamos os métodos de estudo com relação a disciplina de anatomia, quanto ao ensino remoto?

51 respostas

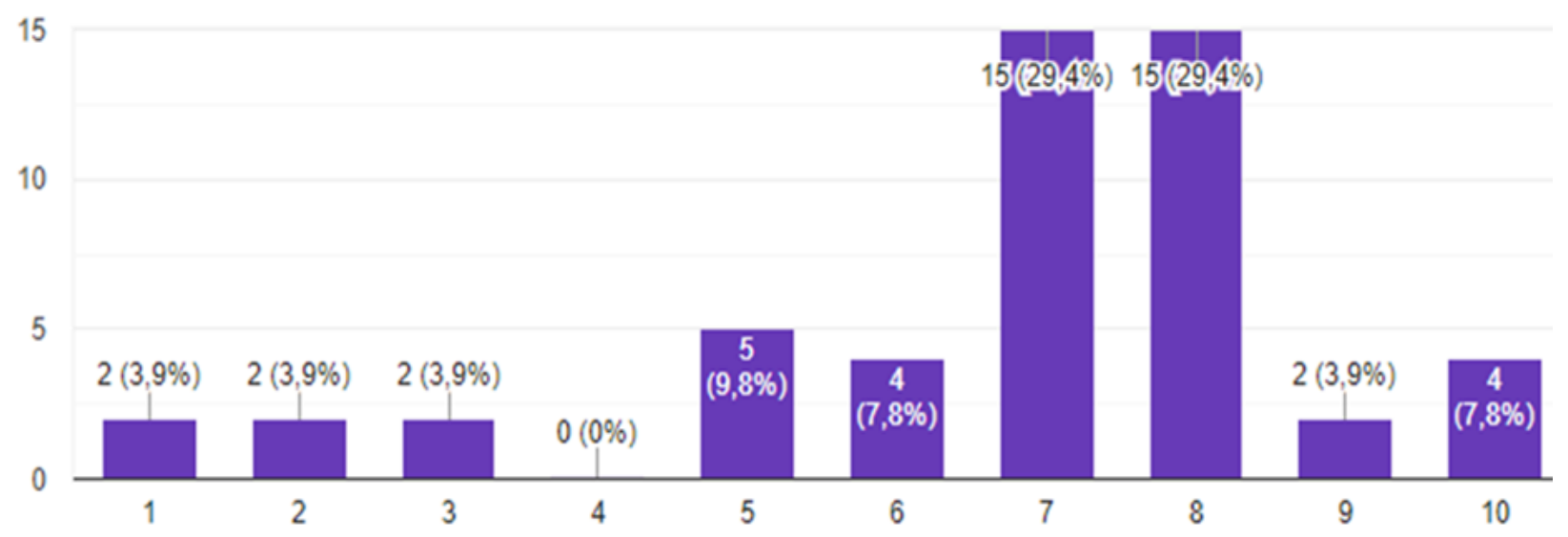

Fonte: Autoria própria.

Em relação as questões 6 até a 9, os alunos responderam suas percepções sobre o aproveitamento dos estudos na forma remota, quanto foi positivo o uso do laboratório virtual para a disciplina de anatomia quando comparado a forma 
presencial. Na literatura temos diversos artigos que tratam das formas metodológicas para o ensino de anatomia.

A pandemia transformou não só o nosso cotidiano, mas forçou novas adaptações em todo os setores, e a educação não fugiu a esse contexto. É necessário repensar me novas práticas educacionais, novas metodologias, aprimorar processos já existentes de ensino e aprendizagem. Esses processos levam os docentes a pensar em novas práticas pedagógicas ou estratégias para enfrentar essa realidade e diminuir assim as deficiências que possam surgir, tendo os alunos como ponto central dessa discussão (DA SILVA FILHO, 2020).

O docente tendo consciência que seu aluno tem uma forma particular de aprender precisa oferecer diferentes possibilidades de apresentação das temáticas propostas para esse aluno, permitindo ao aluno ter uma maior chance de aprender o que foi proposto em aula.

Um estudo com o emprego da realidade virtual foi proposto para um grupo de alunos de medicina, tendo como proposta o estudo da anatomia do coração humano através de 03 métodos diferentes de aprendizado. O grupo que estudou em ambiente virtual obteve melhores resultados no teste realizado após as práticas de ensino do que os alunos que estudaram apenas com textos referentes ao tema proposto ou através de imagens 3D apenas (DOS SANTOS, 2020).

Esses dados também coincidem com as respostas apresentados pelos nossos alunos, pois quase a totalidade dos alunos responderam de forma positiva o estudo de forma remota e o uso do laboratório virtual para o aprendizado do conteúdo prático da anatomia. Os recursos utilizados pelos alunos participantes vão desde aulas síncronas como o uso de imagens cadavéricas em 3 e vídeos.

Garas et al. (2018), mostraram uma pesquisa realizada com 23 alunos da área da saúde, aonde foi oferecido 03 formas para estudar as peças, sendo um modelo 3D, peças cadavéricas e sintéticas. Nesse estudo as peças 3D foram classificadas como as fáceis de serem identificadas e ainda $85 \%$ dos participantes assinalaram as respostas corretas nas peças impressas em 3D, quando comparadas as peças cadavéricas ou sintéticas. $74 \%$ desses alunos consideraram as peças impressas em 3D como a forma ideal para o aprendizado anatômico. Cruz (2020) apresentou uma pesquisa sobre os desafios da monitoria da disci- 
plina de anatomia humana no ensino remoto emergencial. Do total dos alunos entrevistados $47,1 \%$ disseram que contribuiu muito para a aprendizagem da anatomia e $52,9 \%$ gostaram muito do método de ensino remoto.

Esses dados vão de encontro com o padrão de reposta observados em nossa pesquisa, pois a percepção dos alunos em relação as aulas remotas foram muito positivas principalmente no uso do laboratório virtual, aonde $76,5 \%$ dos alunos que responderam à pesquisa afirmaram que contribuiu muito ao estudo da disciplina (figura 6). Outros aspectos também facilitaram, como a proximidade com o professor, que foi determinante para o sucesso desse método, pela facilidade de assistir as aulas gravadas, poder voltar a aula quando não entendeu (gravada), acessar de qualquer lugar e qualquer dispositivo foram os pontos mais destacados pelos alunos.

Figura 6. Contribuição do laboratório virtual para disciplina de anatomia

\section{Você considera que o uso do laboratório virtual contribuiu no aprendizado da disciplina de} anatomia?

\section{1 respostas}

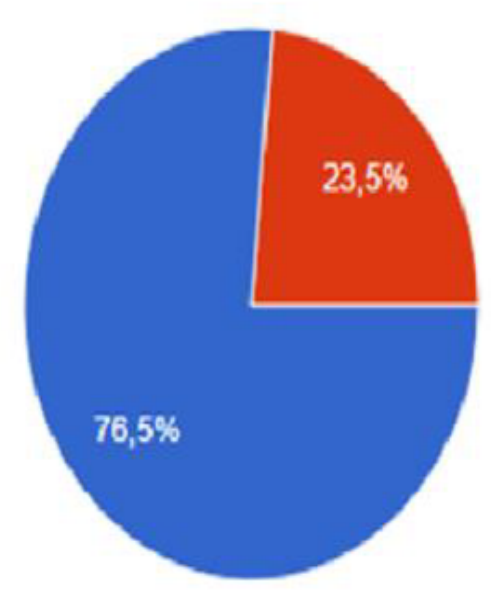

Sim, contribuiu muito

Não

Autoria própria.

Por outro lado, de forma negativa os alunos relataram que alguns tiveram problemas de conexão o que impediu assistir as aulas de forma síncrona (mas assistiu depois a aula gravada), e o ponto mais abordado foi o uso do laboratório de anatomia de forma presencial, apesar da grande maioria dos entrevistados apontaram que as ferramentas digitais facilitaram o aprendizado, o laboratório de anatomia com todo o seu acervo poderia estar associado as aulas remotas. 


\section{CONCLUSÃO}

Essa pesquisa colabora com estudos que verificam a constante transformação da educação e de novas formas de aprendizagem, sendo determinadas pelo cenário que estamos vivendo. Isso se faz necessário para acompanhar a velocidade que o mundo evolui e a capacidade de termos informações de diferentes modos e lugares. Cabe ao docente acompanhar essas transformações e se adaptar para os desafios que se apresentam e aqueles que ainda estão por vir. A pandemia mudou radicalmente a forma de enxergarmos o mundo em que vivemos, mas também nos ofereceu oportunidades de crescermos como pessoas e profissionais, a cada novo desafio uma nova proposta de evolução e aprendizado.

Notamos através dessa pesquisa que os alunos, ponto principal dessa discussão, se adaptaram muito rápido a essa nova realidade de ensino e aceitaram esses novos métodos de uma forma muito tranquila, o que favoreceu o aprendizado. A percepção dos mesmos em relação especificamente a disciplina de anatomia foi que o uso do laboratório virtual contribuiu de forma positiva para o aprendizado, facilitando o estudo e por consequência um melhor desempenho de aprendizagem.

\section{REFERÊNCIAS}

ALQAHTANI, M.; MOHAMMAD, H. Mobile applications' impact on student performance and satisfaction. Turkish Online Journal of Educational Technology-TOJET, v. 14, n. 4, p. 102-112, 2015.

ARRUDA, E. P. EDUCAÇÃO REMOTA EMERGENCIAL: elementos para políticas públicas na educação brasileira em tempos de Covid-19. EmRede - Revista de Educação a Distância, v. 7, n. 1, p. 257-275, 15 de mai 2020.

BERWANGER, Perla Maria; JUNIOR, João Batista Bottentuit. Mobile Leraning no Ensino Superior: uma cartografia a partir das percepções dos docentes. Revista Teias, v. 21, p. 59-73, 2020. 
BOFF, Tália Cássia et al. O uso da tecnologia no ensino da anatomia humana: revisão sistemática da literatura de 2017 a 2020. Medicina (Ribeirão Preto), v. 53, n. 4, p. 447-455, 2020.

BRASIL. Ministério da Educação. Portaria n. 544 de 16 de junho de 2020. Dispõe sobre a substituição das aulas presenciais por aulas em meios digitais, enquanto durar a situação de pandemia do novo coronavírus - Covid-19. Disponível em: http://www.in.gov.br/en/web/dou/-/portaria-n-544-de-16-de-junho-de-2020-261924872 . Acesso em: 12 de mar. 2021

BUENO, Maria Bethânia Tomaschewski; BUENO, Mateus Moreira; MOREIRA, Maria Isabel Giusti. Fisioterapia e a educação em saúde: as tecnologias educacionais digitais como foco. Revista Thema, v. 17, n. 3, p. 675-685, 2020.

CAHILL, Donald R.; LEONARD, Robert J. The role of computers and dissection in teaching anatomy: a comment. Clin Anat, v.10, no. 2, p.140-141, 1997.

CRUZ, Ântony; MATIAS, Vanessa Fideles; RUYBAL, Mara Cristina Pimenta Dos Santos. OS DESAFIOS DA MONITORIA DE ANATOMIA HUMANA NO ENSINO REMOTO EMERGENCIAL. Anais do Salão Internacional de Ensino, Pesquisa e Extensão, v. 12, n. 1, 2020.

DA SILVA FILHO, Francisco Cezimar; PEREIRA, Andresa Costa. O uso de jogos digitais para o ensino da anatomia humana: um relato de experiência. Research, Society and Development, v. 9, n. 9, p. e261996602-e261996602, 2020.

DA SILVA, Luciano Ferreira; RUSSO, Rosária de Fátima Segger Macri; DE OLIVEIRA, Paulo Sergio Gonçalves. Quantitativa ou qualitativa? um alinhamento entre pesquisa, pesquisador e achados em pesquisas sociais. Revista Pretexto, p. 30-45, 2018.

DALESSANDRO, Rafael Cacciolari; CASTANHA, Rafael Gutierres; JUNIOR, Wilson Roberto Veronez. A produção científica relacionada a fake news: uma análise bibliométrica na base de dados Scopus. Revista Conhecimento em Ação, v. 5, n. 2, p. 2-16, 2020.

DE MEDEIROS, João Heitor Basílio et al. Desafios do ensino superior durante a pandemia do covid-19: relato de experiência da monitoria de anatomia humana. Brazilian Journal of Development, v. 6, n. 10, p. 84008-84015, 2020. 
DOS SANTOS, Ana Maria Pujol Vieira et al. O processo de ensino e aprendizagem de anatomia humana: uma avaliação de estratégias. Ensino, Saude e Ambiente, v. 13, n. 3, p. 362-372, 2020.

ÉRIKA, C.; SOARES, Elane Chaveiro; BARROS, Marcelo Paes. Espia lá-Mato Grosso-aplicativo educacional em dispositivo móvel para a formação continuada de professores. Revista Polyphonía, v. 25, n. 2, p. 151-163, 2014.

FORNAZIERO, Célia Cristina; GIL, Célia Regina Rodrigues. Novas tecnologias aplicadas ao ensino da anatomia humana. Revista Brasileira de Educação Médica, v. 27, n. 2, p. 141-146, 2003.

GARAS, Monique et al. 3D-Printed specimens as a valuable tool in anatomy education: A pilot study. Annals of Anatomy-Anatomischer Anzeiger, v. 219, p. 57-64, 2018.

GARCIA, Alexandro Ferreira; RITO, Jéssica Grisiane Aprijo Cordeiro. Tecnologia: ferramenta de estratégia para o ensino na educação superior. Revista Científica Novas Configurações-Diálogos Plurais, v. 1, n. 2, p. 11-15, 2020.

HAMDAN, Khaed; BEN-CHABAN, Yazid. An interactive mobile learning method to measure students performance. In: 12th World Conference on Mobile and Contextual Learning (mLearn 2013). Hamad bin Khalifa University Press (HBKU Press), p. 26, 2013.

LIMA, Taciana Carvalho. Novas tecnologias aplicadas ao estudo de Anatomia Humana. REVISTA DE TRABALHOS ACADÊMICOS-UNIVERSO BELO HORIZONTE, v. 1, n. 3, 2018.

MITROUSIAS, Vasileios et al. Anatomy learning from prosected cadaveric specimens versus three-dimensional software: A comparative study of upper limb anatomy. Annals of Anatomy-Anatomischer Anzeiger, v. 218, p. 156-164, 2018.

NANI, Sérgio Garzon Batista et al. Desenvolvimento de aplicativos educacionais para auxílio no estudo de anatomia de estudantes do ensino superior. In: Anais do CIET: EnPED: 2020-(Congresso Internacional de Educação e Tecnologias| Encontro de Pesquisadores em Educação a Distância). 2020.

SANTOS, José Ozildodos; DE SOUSA SANTOS, Rosélia Maria. O uso do celular como ferramenta de aprendizagem. Revista Brasileira de Educação e Saúde, v. 4 , n. 4 , p. 1-6, 2015. 
SOUZA, Katia Reis de et al. Trabalho remoto, saúde docente e greve virtual em cenário de pandemia. Trabalho, Educação e Saúde, v. 19, 2020.

VILELA, Gabriella Queiroz da Silva; SOUZA, Marina Santiago de Mello; Bacellar, TRINDADE, Fatima Cristina. O Uso de Aplicativos de Anatomia Humana para Smartphone em Cursos de Graduação na Área da Saúde. Revista Tecnologias na Educação, v.25, 2018. 
doi 10.48209/978-65-89949-13-5

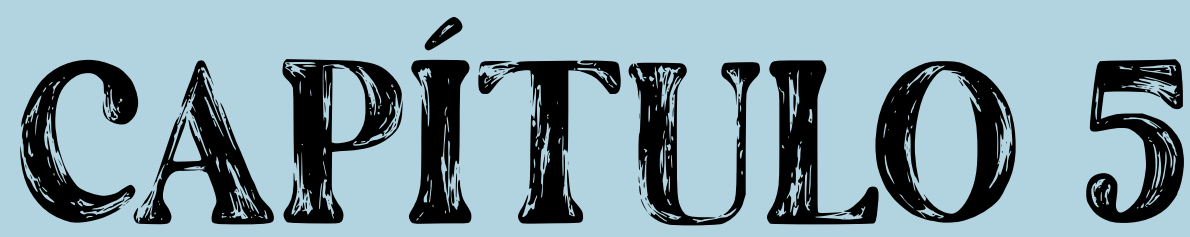

\section{SMARTPHONE NO ENSINO DE BIOLOGIA: UMA INCLUSÃO URGENTE NA EDUCAÇÃO BÁSICA}

Camilla Carvalho Gomes Andre Santos Amorim Karina Carvalho Mancini 


\section{INTRODUÇÃO}

Diante da infinita variedade de informações que se atualizam constantemente por meio da internet, o aluno tem se tornado cada vez mais um sujeito ativo, responsável por seu processo de aprendizagem, procurando e selecionando informações de acordo com o seu interesse e necessidade (REIS et al., 2012). Mais do que isso, a tecnologia faz parte do cotidiano do aluno, uma vez que a geração atual não conheceu o mundo sem computadores e smartphones (CERETTA; FROEMMING, 2011). Neste interim, Silva (2005) já apontava que se a escola não passar a incluir a internet na educação das novas gerações, ela está na contramão da história, alheia ao espírito do tempo.

Diante do cenário pandêmico causado pelo novo coronavírus (SARS-CoV-2), no ano de 2020, houve a necessidade de isolamento social e, com isso, a implantação do ensino remoto emergencial (ERE) nas escolas de educação básica e superior. Diferente do ensino a distância (EaD), estruturado desde o seu planejamento inicial para ser totalmente online durante o período do desenvolvimento do curso, o ERE não envolve "[...] recriar um sistema educacional robusto, mas fornecer acesso temporário a suportes e conteúdos educacionais de maneira rápida, fácil de configurar e confiável, durante uma emergência ou crise" (HODGES et al., 2020, p.06). De acordo com Silveira, 2020, p.38:

A EaD deve privilegiar a interação mediada por diferentes tecnologias, tais como a Internet, com apoio pedagógico e de infraestrutura tecnológica para os professores e para os alunos. Sendo assim, o que os docentes de diferentes instituições de ensino estão desenvolvendo, no momento, é o ensino remoto e não a EaD propriamente dita, até mesmo porque a maioria das instituições de ensino, que atuam na modalidade presencial, não possuem infraestrutura tecnológica para dar suporte às atividades em EaD e, também, não prepararam seus docentes para atuarem neste contexto.

O ERE apresenta vários desafios, como, por exemplo, a utilização de ferramentas tecnológicas, o preparo das atividades e a participação dos estudantes na realização dos exercícios propostos (QUEIROZ et al, 2020). Nesse contexto, segundo Borba et al. (2020, p. 154): 
Enclausurados em suas residências, milhares de professores encontram-se às voltas com o drástico tensionamento dos modelos de docência que conheciam, praticavam e nos quais se constituíram profissionais da educação. Ao passar de exíguos dias, condicionados por diferentes pressões dos estudantes, das famílias, dos gestores escolares, deixaram os papéis de consumidores das mídias e redes sociais para tornarem-se produtores de artefatos consubstanciados com a mesma matéria digital que pavimenta o mundo virtual.

No entanto, apesar da necessidade de trilhar novas ferramentas metodológicas no ERE, muitos docentes não possuem experiência em trabalhar com as Tecnologias de Informação e Comunicação (EduTICs) e se frustram ao tentar criar e até mesmo usar conteúdos e estratégias de ensino neste novo formato. Nesse sentido, Lago e Brito (2010) evidenciam que, como a maioria dos professores que atua hoje nas escolas não foi contemplada em sua formação universitária com o uso das novas tecnologias, estes necessitam de uma formação continuada que abarque o uso dessas ferramentas para a educação, compreendendo o que são e como utilizá-las.

Com a popularização dos dispositivos móveis, cujo maior destaque são os smartphones, e a crescente expansão dos sistemas de comunicação por redes sem fio, vive-se um período em que a mobilidade, a conectividade e a ubiquidade influenciam as instituições e o modo de viver da sociedade (SILVA; FALAVIGNA, 2016). Assim, utilizar os smartphones como ferramenta na educação pode ser uma alternativa valiosa para o ERE em tempos de pandemia.

Desta forma, o presente capítulo representa um fragmento da dissertação de mestrado 'Smartphone na Educação Básica: possibilidades e desafios no Ensino de Biologia em escolas da rede pública de São Mateus-ES' (GOMES, 2019), elaborada no âmbito do Programa de Pós-graduação em Ensino na Educação Básica da Universidade Federal do Espírito Santo (UFES), que fundamenta e defende o uso dos smartphones no ensino e apresenta um guia de aplicativos educacionais, gratuitos e em português. A pesquisa visou verificar a distribuição e qualidade dos aplicativos por áreas de conhecimento da Biologia, disponibilizando essa ferramenta de aprendizagem e motivação de modo a contribuir com o ensino de Biologia durante o ERE e no cenário educacional pós-pandêmico. 


\section{USANDO O QUE JÁ ESTÁ À MÃO}

Conforme pesquisa TIC Domicílios, realizada pelo Comitê Gestor da Internet no Brasil (CETIC, 2020), em 2019 o smartphone foi o dispositivo usado por 99\% dos usuários brasileiros para conexão com a internet. Com o cenário de pandemia, isolamento social, home office e ensino remoto, esses números elevaram-se significativamente. Em um levantamento feito em janeiro de 2021, o Brasil registrou 205,4 milhões de usuários de smartphones (96,3\% da população) (DATAREPORTAL, 2021). Sobre a questão, segundo Balardini (2008), os aparelhos celulares têm o status de ícones identitários dos jovens. Nesse sentido, Prensky (2010) descreve essa perspectiva com o testemunho de um aluno japonês, ao dizer: "quando você perde seu celular, perde parte do cérebro".

Com o uso de dispositivos móveis a mobilidade ganha características tecnológicas, pois permite a utilização de um dispositivo em diferentes localidades e dá acesso à informação, não importando o fato em si, mas a capacidade de ser distribuída, compartilhada e acessada por um ou muitos usuários. Santaella (2013) acrescenta que a condição contemporânea é ubíqua, pois estamos, ao mesmo tempo, em algum lugar e fora dele. A ubiquidade pode ser entendida como a capacidade de se comunicar a qualquer tempo e hora, por intermédio de ferramentas móveis (SANTOS; WEBER, 2013).

Por esse motivo, os smartphones merecem destaque quanto às inúmeras e crescentes alternativas de uso direcionadas para o ensino, especialmente para aquelas disciplinas que necessitam de aulas experimentais e possuem conteúdos mais abstratos (BARBOSA et al., 2017). Na educação, essas tecnologias móveis têm alto potencial de expandir a aprendizagem limitada à sala de aula, uma vez que permitem o acesso a materiais educativos independentemente do local e do tempo (MOURA, 2010). Em 2013, a Organização das Nações Unidas para a Educação, Ciência e Cultura (UNESCO) divulgou um guia com recomendações para estimular os governos a elaborarem políticas públicas educacionais que valorizem o uso de celulares como um recurso nas escolas (UNESCO, 2013). 
Pela capacidade de proporcionar interação nas práticas educativas e viabilizar acesso interativo ao ambiente escolar, a qualquer tempo e lugar, com o uso de dispositivos móveis surge o termo "aprendizagem com mobilidade" (mobile learning) (SACCOL et al., 2010). O mobile learning permite aos alunos obterem materiais didáticos em qualquer lugar e a qualquer momento por meio de tecnologias móveis (MAHAT et al., 2012). Assim, em um ambiente de aprendizagem móvel, os conteúdos podem ser trabalhados sem limitação de tempo ou espaço, proporcionando dessa forma mobilidade e portabilidade através de iPads, laptops, tablets, palms, notebooks e smartphones (FEDOCE; SQUIRRA, 2011). Vale destacar que, entre os dispositivos móveis, o smartphone é o mais popular e acessível e, como observa Merije (2012, p. 81), "[...] se o computador ainda é um objeto restrito, o celular está presente em boa parte das escolas, nas mochilas dos alunos de diferentes classes sociais".

Vários casos de sucesso no campo do mobile learning emergiram nos últimos anos em diversos países do mundo: 'Jokko Initiative'; 'Programa Nacional de Alfabetização' e 'Mobiles for Supervisors'; EcoMUVE; 'Janala Project' entre outros. No Brasil, destacam-se dois grandes projetos: 'Celular na Escola', da Fundação Vanzollinni; e 'Minha Vida Mobile - MVMob'. Esse conjunto de ações revela motivos para a apropriação de dispositivos móveis para os processos de ensino e aprendizagem desenvolvidos nas escolas, estando entre eles a viabilidade de uma resposta imediata, aprendizagem esta que pode ser considerada como do tipo "a qualquer hora, em qualquer lugar", sendo uma ferramenta de suporte para o estudo no próprio local de ensino (FONSECA, 2013). Entretanto, há de se considerar os desafios e dificuldades no uso de smartphones em sala de aula como, por exemplo, a dispersão e distração dos alunos, apontadas por Lopes e Pimenta (2017).

\section{AS DIFICULDADES E RESISTÊNCIA NAS ESCOLAS}

Apesar da disseminação diária e mundial dos smartphones, de seus benefícios para o processo de ensino e aprendizagem e da crescente tendência do mobile learning, o uso desses aparelhos móveis por crianças e adolescentes tem 
sido alvo de resistência e polêmicas nas escolas que vão desde questões que violem a etiqueta escolar convencional até problemas mais complexos, como a disseminação de conteúdo inadequado, gerando restrições e até proibições para o seu uso nos espaços escolares (VIVIAN; PAULY, 2012).

Em 2008, alguns estados brasileiros proibiram legalmente o uso de smartphones (RIO GRANDE DO SUL, 2008; SANTA CATARINA, 2008) nas escolas sob justificativa de que a utilização em sala de aula pode causar a distração do aluno, afetando o seu rendimento escolar e atrapalhando a didática dos professores. Apesar disso, o Ministério da Educação vem apoiando propostas de incorporação das tecnologias à educação, criando e fortalecendo redes de aprendizagem como, por exemplo, a Universidade Aberta (BRASIL, 2005), o Proinfo (BRASIL, 2007) e o Portal do Professor (BRASIL, 2008).

De acordo com Morris (2010), os professores têm dificuldades em se familiarizar com a linguagem digital de seus alunos, reduzindo assim significativamente o potencial de sua aprendizagem por meio do mobile learning. Dessa forma, o smartphone, que geralmente já está nas mãos do aluno, não é ainda usado de forma pedagógica (OLIVEIRA, 2014).

Para Prensky (2001), os estudantes são verdadeiros nativos digitais, pois nasceram em meio ao grande desenvolvimento tecnológico e cresceram entre computadores, videogames, câmeras digitais e smartphones. Por outro lado, a maioria dos professores integra o grupo denominado de imigrantes digitais, que nasceram em um mundo não digital e que dificilmente perdem seus costumes, como, por exemplo, ter agenda de papel e materiais impressos. Dessa forma, professores e alunos falam diferentes linguagens. O autor ainda destaca que:

Professores imigrantes digitais presumem que os aprendizes são os mesmos que sempre foram, e aqueles mesmos métodos que funcionaram para os professores quando eles eram estudantes irão funcionar para seus estudantes de agora (PRENSKY, 2001, p. 3).

Diante dessa questão, considera-se que, muitas vezes, o docente se permite reconhecer o valor da tecnologia para a educação, mas se sente desconfortável com ela e é frustrado pelos currículos atuais (BANYARD; UNDERWOOD, 2008). O discente, por outro lado, é autoconfiante e espontâneo no uso da tec- 
nologia, mas necessita de aprender a utilizá-la por meio de métodos adequados. Nesse sentido, gestores escolares e professores precisam ter consciência de que a cultura primeira do aluno, aquela que obtida fora do ambiente escolar, de forma não metódica, é a midiática, em decorrência da sociedade em que se vive.

Para além do cenário descrito, é fato que a pandemia provocada pelo coronavírus SARS-CoV-2 causou uma impositiva aceleração no processo de aceitação do uso de EduTICs, e os professores, mesmo com dificuldades, têm produzido conteúdos digitais significativos. Borba et al. (2020) apontam que, entre as principais atividades e materiais desenvolvidos e utilizados por 187 professores brasileiros em tempos de pandemia, ou seja, no ensino remoto, estão: listas de exercícios, estudos dirigidos, ambientes virtuais de aprendizagem, vídeos e documentários da internet, textos de divulgação científica, aulas online, gravações de aulas, aulas de outros professores, jogos, entre outros.

Diante do exposto, partimos da premissa que o uso direto dos smartphones, mesmo em tempos de pandemia e de ensino remoto, ainda se apresenta conspícuo. Por esta razão, o presente estudo trabalhou na elaboração de um guia de aplicativos para o ensino de biologia, no intuito de incentivar professores a fazerem uso dessa ferramenta em sua prática docente.

\section{O ENSINO DE BIOLOGIA}

Quando analisamos conjuntamente o uso frequente de smartphones, a resistência dos professores no uso de EduTICs, o atual momento pandêmico e a imposição remota do ensino, consideramos que há de se buscar alternativas que maximizem o tempo do professor e oportunizem a participação ativa e a motivação dos alunos. A nosso ver, uma dessas alternativas é a utilização de aplicativos desenvolvidos para fins educacionais e que estão à disposição dos usuários de forma gratuita e em língua portuguesa.

Com relação ao ensino de Biologia, segundo Santos (2009), os conteúdos trabalhados muitas vezes não motivam os alunos e ainda os distanciam da realidade, tornando o aprendizado pouco significativo e a Biologia em uma disciplina meramente teórica, voltada a memorização dos conteúdos, não permitindo que 
eles correlacionem com fenômenos biológicos do cotidiano (GIANOTTO; DINIZ, 2010). Nesse sentido, Krasilchik (2004) afirma que a Biologia pode ser uma das disciplinas mais significativas para os alunos, ou sem nenhuma relevância, e isso vai depender do que for lecionado e de quais estratégias de ensino serão utilizadas.

Aprender Biologia implica identificar os processos que ocorrem na natureza, compreendo-os e associando-os ao cotidiano. Entretanto, o ensino mecânico, onde os alunos decoram nomes, conceitos e sistemas não permite que eles correlacionem e compreendam os fenômenos biológicos (GIANOTTO; DINIZ, 2010). Diante desse cenário, propostas relacionadas à utilização de tecnologias no processo de ensino e aprendizagem podem ser extremamente úteis e significativas na aplicação dos conteúdos de Biologia. Diante disso, disponibilizamos, a seguir, um guia de aplicativos voltados para diferentes áreas de conhecimento da Biologia, de modo a permitir aos professores acesso a conteúdos dinâmicos e atualizados.

\section{PERCURSO METODOLÓGICO}

Para a obtenção de um guia de aplicativos educacionais, desenvolvidos para dispositivos móveis, com foco no ensino de Biologia para professores e estudantes do ensino médio, foi desenvolvida uma pesquisa de natureza qualitativa do tipo exploratória. De acordo com Gil (2017), a pesquisa exploratória tem por objetivo o aprimoramento de ideias ou a descoberta de intuições, sendo seu planejamento bastante flexível, de modo a possibilitar a consideração dos mais variados aspectos relativos ao fato estudado.

Quanto ao procedimento, foi aplicada uma revisão narrativa por não apresentar critérios rigorosamente padronizados para busca de documentos. Este tipo de estudo constitui-se a partir de um levantamento da literatura e da análise crítica pessoal do pesquisador (BERNARDO; NOBRE; JANETE, 2004), possibilitando a atualização de dados em um curto período sem a utilização de abordagens quantitativas (ROTHER, 2007). Todavia, reconhecemos as limitações do 
procedimento escolhido e a necessidade de realização de um posterior levantamento bibliográfico rigorosamente padronizado e sistematizado.

Desta forma, usando a flexibilidade permitida na pesquisa do tipo exploratória e de revisão narrativa, foram selecionados aplicativos respeitando os seguintes critérios:

a. Envolver conteúdos de Biologia trabalhados no Ensino Médio. Para isso, foram usadas diversas palavras-chaves para abranger as diferentes áreas de conhecimento em Biologia;

b. Estar disponível nas lojas virtuais google play store e app store;

c. Ter compatibilidade com sistemas Android e IOS;

d. Ter sido desenvolvidos em língua portuguesa, excluindo aplicativos em outros idiomas, para facilitar a compreensão das normas, uso e conteúdos pelos professores e principalmente pelos estudantes;

e. Ser de uso gratuito;

f. Apresentar uma boa avaliação dos usuários;

g. Estar ativo. Para tanto, todos os aplicativos foram instalados e testados.

Os aplicativos encontrados e testados foram categorizados segundo as áreas de estudo da Biologia. Para cada aplicativo seguiu-se o ícone de identificação, a descrição da proposta de interação (animação, atividade, jogo, livro, simulação, atlas fotográfico, quizz, dicionário) e uma breve descrição do uso.

\section{GUIA DE APLICATIVOS EDUCACIONAIS}

O Quadro 1 apresenta os aplicativos educacionais encontrados voltados para conteúdo de Biologia que estão ativos e disponíveis para dispositivos móveis. 


\section{Quadro 1 - Relação de aplicativos ativos e suas funcionalidades educacionais para diferentes áreas da Biologia}

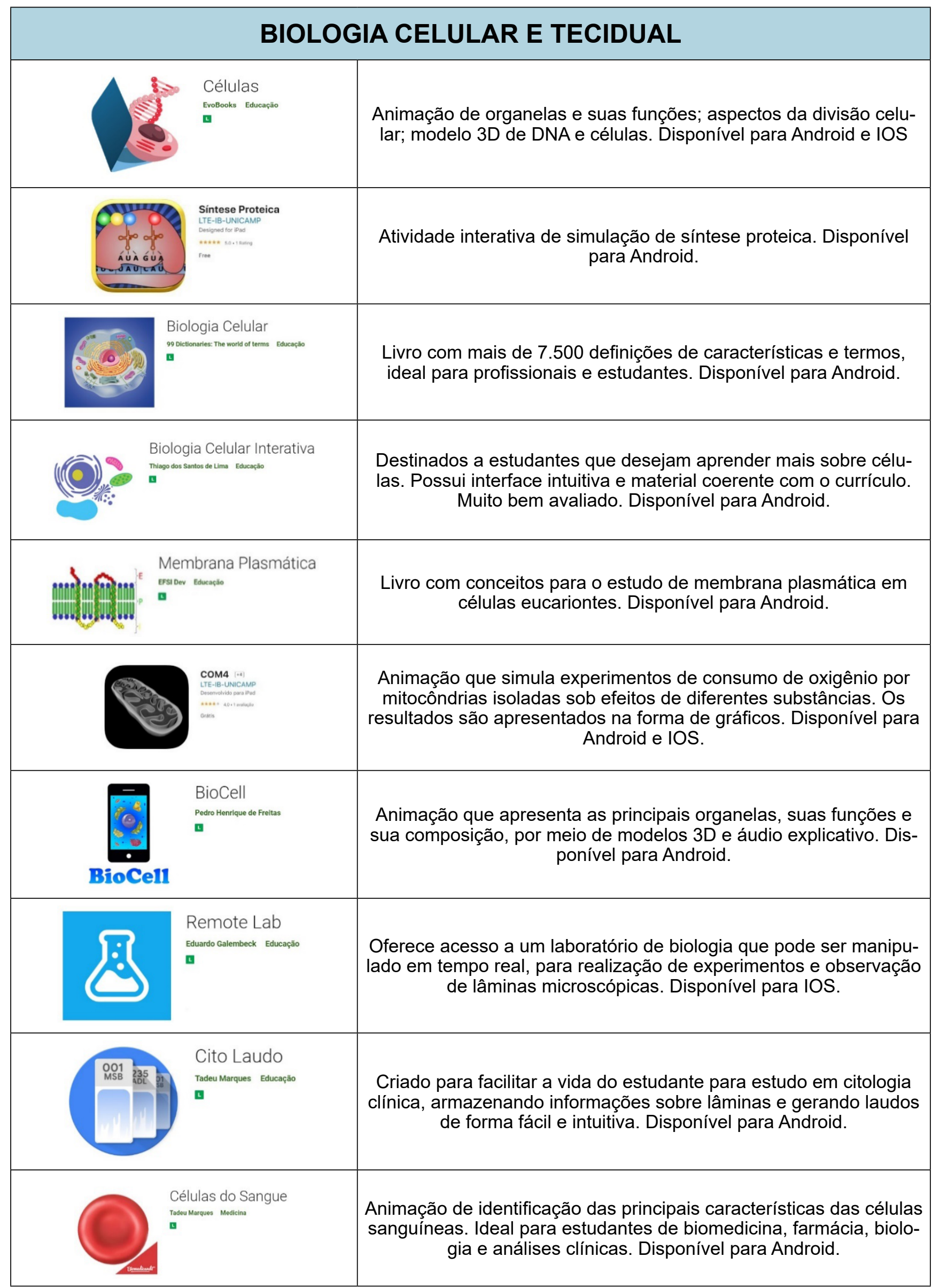




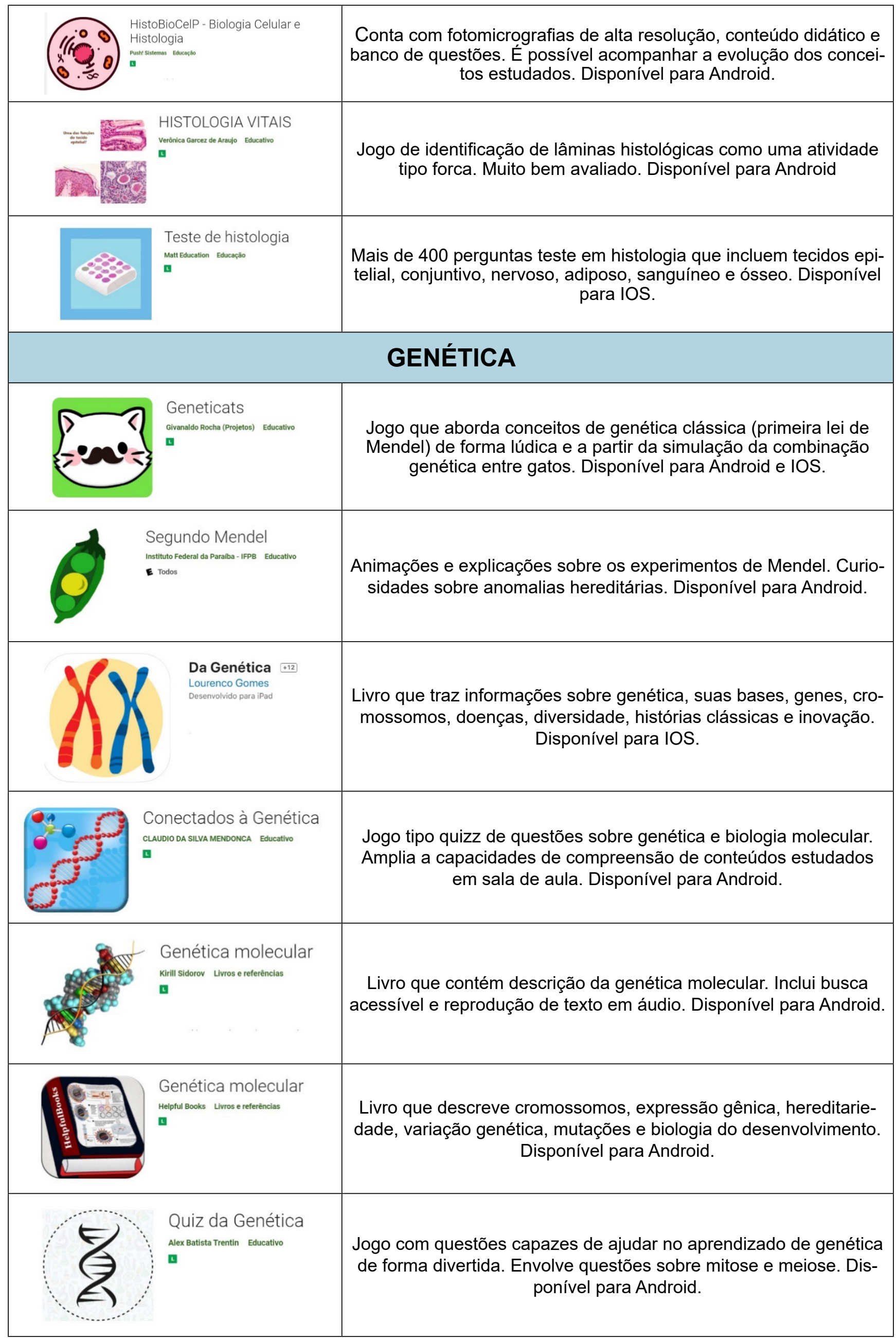




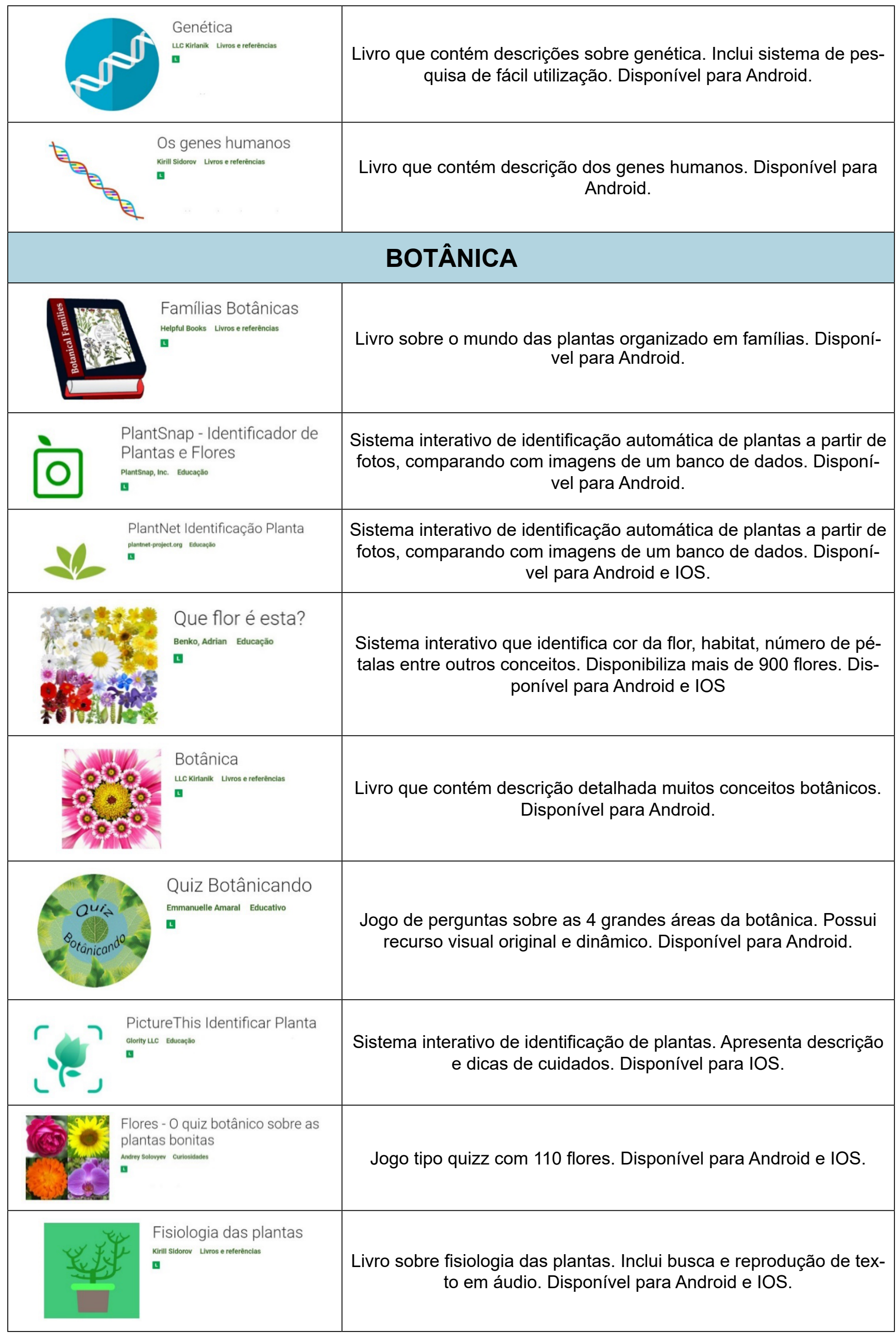




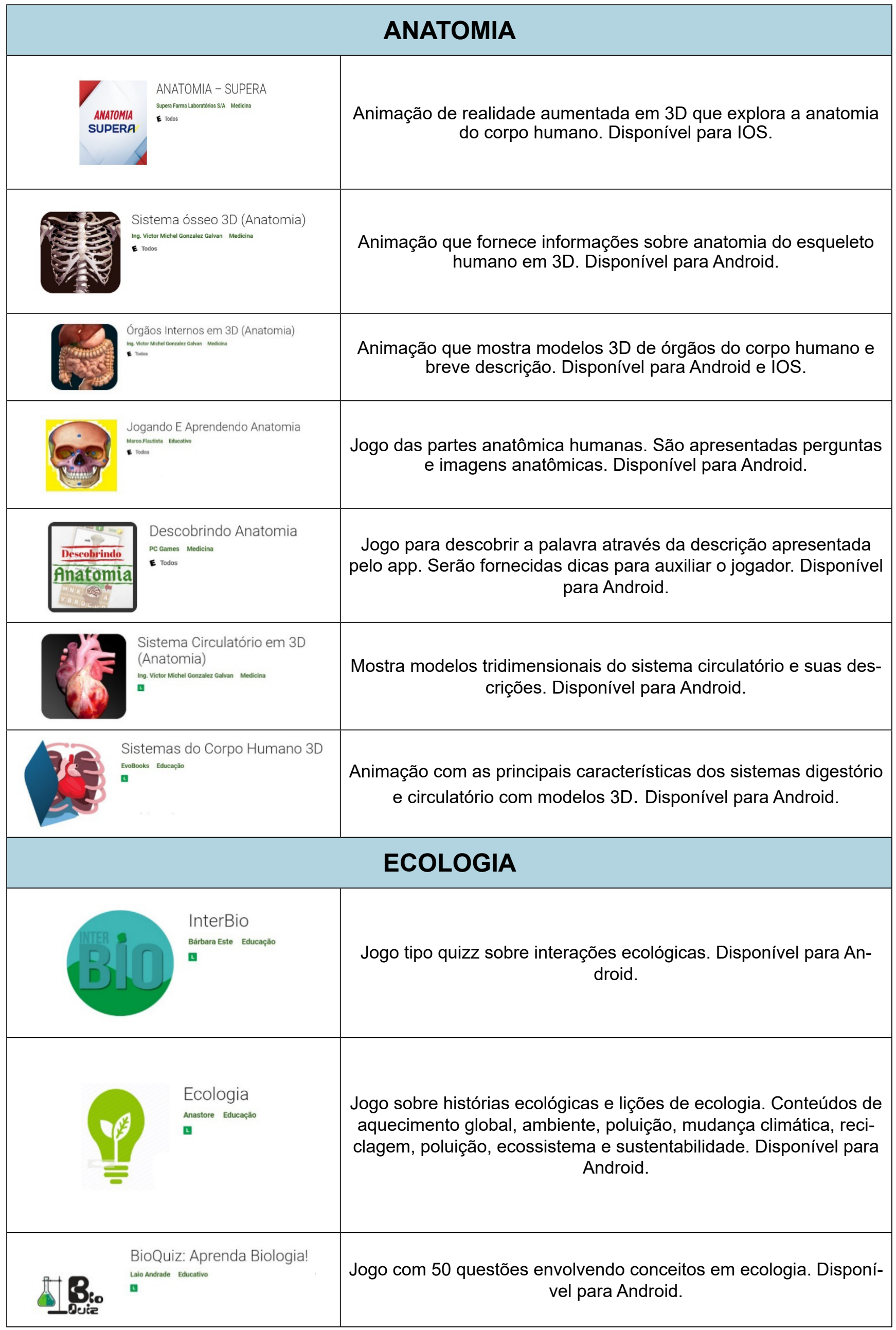




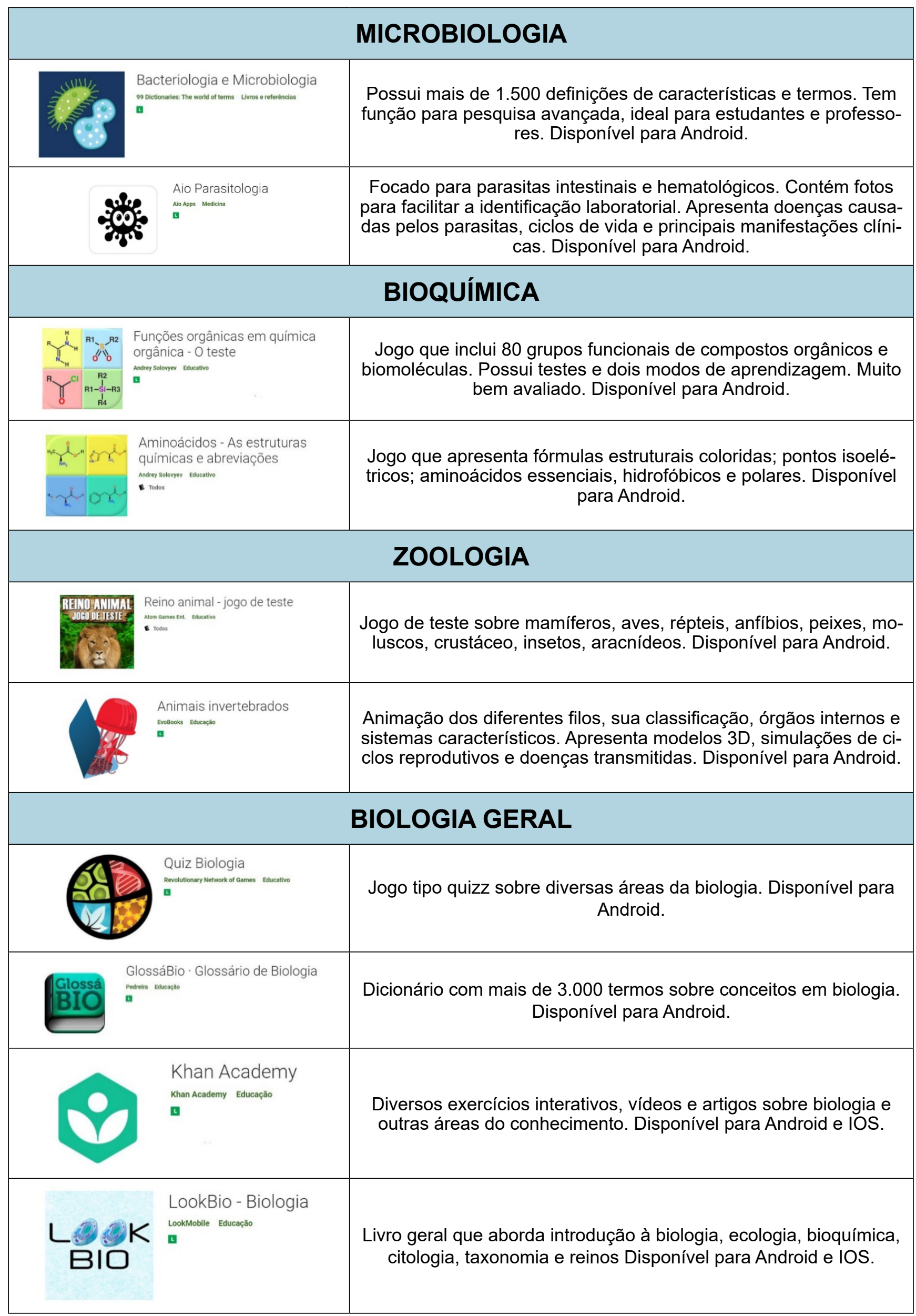

Fonte: Autores 
Durante a busca, foram encontrados inúmeros aplicativos com potencial pedagógico. Entretanto, uma parcela significativa: a) não está em língua portuguesa; b) não é gratuito; c) foi mal avaliado pelos usuários; d) não está mais ativo; e) não apresenta atualização além da versão teste. Ademais, o sistema operacional para Android possui muito mais alternativas em português, enquanto o sistema IOS é fortemente voltado para a língua inglesa. Cabe ressaltar que, no Brasil, o sistema operacional mais utilizado é o Android, o que justifica a abundância de aplicativos em língua portuguesa.

A Biologia Celular e Tecidual foi a área de conhecimento das Ciências Biológicas que mais apresentou aplicativos. Muitos não foram colocados no Quadro 1 por estarem inativos, mas a quantidade registrada no google play store e app store é destaque entre as áreas que integram a Biologia. Segundo Orlando et al. (2009), essa área constitui um dos conteúdos que mais requer a elaboração de material de apoio ao conteúdo presente nos livros, já que emprega conceitos abstratos e trabalha aspectos microscópicos. Por essa razão, os recursos destes aplicativos se concentram em animações 3D, na tentativa de colaborar com a compreensão da arquitetura celular e tecidual.

As áreas de Genética e Botânica também apresentaram grande variedade de aplicativos. Para Genética, tal abundância de aplicativos se deve provavelmente ao fascínio que a subárea proporciona e às dificuldades que os alunos têm em relação à compreensão de seus conceitos. Segundo Banet e Ayuso (2003), a Genética tem sido um dos conteúdos que mais despertam pesquisas na área de ensino Biologia por envolver relevância social e econômica, implicações tecnológicas e éticas e por estar sempre presente nos meios de comunicação. Apesar da evidente importância, Goldbach e El-Hani (2008) apontam que há diversas pesquisas relacionadas às dificuldades no ensino, principalmente relacionadas às concepções alternativas apresentadas nos livros didáticos e às abordagens pouco integradas e ainda fragmentadas deste conteúdo. Assim, observamos que os aplicativos encontrados concentram-se na proposição de livros e jogos em busca de abordar os conteúdos de Genética com outra linguagem. 
Já na Botânica, vários aplicativos baseiam-se na identificação de plantas pela câmera do celular, o que ocorre por meio do banco de dados do programa, o que, a nosso ver, é uma excelente opção para uma aula de campo nos arredores da escola ou da casa do aluno, visto que pode colaborar para minimizar a dita "cegueira botânica". A cegueira botânica é a principal dificuldade apontada pelas pesquisas em ensino desta área e refere-se à incapacidade de reconhecer a importância das plantas no cotidiano (WANDERSEE; SCHUSSLER, 1999). Segundo Neves; Bündchen e Lisboa (2019), tal incapacidade pode ser minimizada pela inclusão das plantas de forma mais contextualizada e atrativa no cotidiano escolar, promovendo assim o reconhecimento e a valorização da biodiversidade vegetal.

Diante dessas observações, acreditamos que o uso de aplicativos educativos no cenário pós-pandêmico é um dos possíveis inevitáveis caminhos. A aceleração tecnológica provocada pela pandemia forçou os professores do ensino básico e superior a saírem de suas zonas de conforto e explorarem essas ferramentas para criar uma aproximação com seus alunos. Entretanto, deve-se atentar que não basta simplesmente associar novas tecnologias a um "fazer antigo". É preciso produzir "novos modos de fazer", já que o currículo começa a ser reconstruído com a presença dos dispositivos digitais e das novas funções sociais que eles impõem. Por isso, o papel do professor é fundamental, no sentido de conhecê-las e saber o momento exato de utilizá-las (KOEHLER; MISHRA, 2009).

Atualmente o ensino remoto se apresenta como algo cansativo, ineficiente e desmotivador, principalmente em virtude do caos sanitário e social que vivenciamos mundialmente. Todavia, nos parece que o ensino híbrido começa a expandir-se e a apresentar novas facetas à educação. Cabe pontuar que esse tipo de ensino configura-se, então, como um plano de educação que mescla momentos em que o aluno estuda usando o conteúdo virtual, no qual pode controlar quando, onde e como estudar; com momentos em que o conteúdo é repassado pelo professor em sala de aula (CHRISTENSEN; HORN; STAKER, 2013).

A nosso ver, com os aplicativos, o professor pode se concentrar menos em criar conteúdos digitais, cabendo-lhe mais indicar ferramentas educacionais 
já existentes, levando em consideração um equipamento que está disponível à grande maioria dos alunos. Seu uso pode ser feito individualmente ou compartilhado (em grupo), ocorrendo em vários locais, como, por exemplo, a sala de aula, a área externa da escola, no ônibus a caminho de casa, em casa ou durante uma viagem. Nesse âmbito, apesar de dados da Abranet (2021) apontarem que o acesso à internet ainda é um problema para cerca de 40 milhões de brasileiros, vale destacar que, em janeiro de 2021, a média diária brasileira de uso de internet foi de $10 \mathrm{~h}$ e 8 min e o maior segmento de utilização foi na faixa de 13 anos de idade (DATAREPORTAL, 2021).

Ao sistematizarmos o guia de aplicativos para o ensino de Biologia, disponibilizamos ao professor um material de apoio que, ainda que não seja possível ser usado por cada aluno através de seu smartphone, certamente funciona como uma nova fonte de dados para a elaboração/seleção do conteúdo a ser ensinado pelo professor e permite o desenvolvimento de inserções tecnológicas pontuais e coletivas em sala de aula (física e/ou virtual).

\section{CONSIDERAÇÕES FINAIS}

No presente capítulo apresentamos reflexões sobre a importância assumida em relação ao uso de smartphones no âmbito do ensino, principalmente diante do atual momento pandêmico, e um guia com 51 aplicativos educacionais categorizados por 09 áreas de conhecimento da Biologia e descritos segundo sua proposta de interação. As áreas que apresentaram maior disponibilidade de aplicativos foram a Biologia Celular e Tecidual, a Genética e a Botânica.

Superar as barreiras e entraves determinados por uma educação centrada no professor é uma tarefa que exige dedicação, planejamento e disposição para mudanças. Nesse contexto, o uso de smartphones como uma ferramenta pedagógica para o processo de ensino e aprendizagem torna-se um grande desafio e uma nova tendência para escolas e educadores.

Apesar da inevitável abertura para o uso de tecnologias educacionais em sala de aula, principalmente em decorrência do ensino remoto em meio ao atual contexto pandêmico, ainda há grande carência na formação dos docentes. Ade- 
mais, acreditamos que a utilização de aplicativos educacionais cria oportunidades de aprendizagem mais relacionadas às habilidades dos alunos nativos digitais $\mathrm{e}$ não demanda tempo de criação de conteúdos digitais pelos docentes.

A nosso ver, não há como manter um ensino sem uso das EduTICs no cenário pós-pandemia. Que este estudo possa contribuir para a expansão do uso de EduTICs no ensino de Biologia, estimulando o desenvolvimento de programas governamentais de inclusão tecnológica para escolas públicas e para famílias de baixa renda, motivando assim educadores e estudantes dentro e fora da sala de aula. Por fim, apontamos que o ano de 2020 trouxe medo, dor, solidão, e por isso desejamos mudanças acolhedoras, inovadoras e tecnológicas.

\section{REFERÊNCIAS}

ABRANET. Associação Brasileira de Internet. IBGE: $\mathbf{4 0}$ milhões de brasileiros não têm acesso à Internet. São Paulo, SP, 2020. Disponível em: https://www. abranet.org.br/Noticias/IBGE\%3A-40-milhoes-de-brasileiros-nao-tem-acesso-a-Internet-3345.html?UserActiveTemplate=site\#.YO6OG-hKjIW. Acesso em: 13 jul. 2021.

BALARDINI, S. De deejays, floggers y ciber-chabones: subjetividades juveniles y tecnocultura. In: BENDIT, R.; HAHN, M.; MIRANDA, A. (ed.). Los jóvenes y el futuro: procesos de inclusión social y patrones de vulnerabilidad en un mundo globalizado. Buenos Aires: Prometeo Libros, 2008. p. 108-140

BANET, E.; AYUSO, G. E. Teaching of Biological Inheritance and Evolution of Living Beings in Secondary School. International Journal of Science Education, v. 25, p. $373-407.2003$.

BANYARD, P.; UNDERWOOD, J. Understanding the learning space. eLearning Papers, n. 9, p. 4-12. 2008.

BARBOSA, C. D.; SOARES, M. L.; CHAGAS, F. C.; FERREIRA, L. O uso de simuladores via smartphone no ensino de ciência como ferramenta pedagógica na abordagem de conteúdos contextualizados de Física. Revista Scientia Plena, v. 13, n. 1. 2017. 
BERNARDO, W. M.; NOBRE, M. R. C; JANETE, F. B. A prática clínica baseada em evidências. Parte II: buscando as evidências em fontes de informação. Revista da Associação Médica Brasileira, v. 50, n. 1, p. 1-9. 2004.

BORBA, R. C. N. et. al. Percepções docentes e práticas de ensino de ciências e biologia na pandemia: uma investigação da Regional 2 da SBEnBio. Revista de ensino de biologia da SBEnBio, v. 13, n. 1, p. 153-171. 2020.

BRASIL. Ministério da Educação. Universidade Aberta do Brasil. Brasília, DF, 2005. Disponível em: http://portal.mec.gov.br/uab/uab. Acesso em: 22 jul. 2021.

BRASIL. Ministério da Educação. Programa Nacional de Tecnologia Educacional. Brasília, DF, 2007. Disponível em: https://www.fnde.gov.br/index.php/programas/proinfo. Acesso em: 22 jul. 2021

BRASIL. Ministério da Educação. Portal do Professor. Brasília, DF, 2008. Disponível em: http://portaldoprofessor.mec.gov.br/sobre.html. Acesso em: 22 jul. 2021

CERETTA, S. B.; FROEMMING, L. M. Geração Z: compreendendo os hábitos de consumo da geração emergente. Revista Eletrônica do Mestrado Profissional em Administração da Universidade Potiguar, v. 3, n. 2, p. 15-24. 2011.

CETIC. Centro Regional de Estudos para o Desenvolvimento da Sociedade da Informação. Três em cada quatro brasileiros já utilizam a Internet, aponta pesquisa TIC Domicílios 2019. São Paulo, SP, 2020. Disponível em: https:// cetic.br/pt/noticia/tres-em-cada-quatro-brasileiros-ja-utilizam-a-internet-apontapesquisa-tic-domicilios-2019/. Acesso em: 20 mai. 2021.

CHRISTENSEN, C; HORN, M. B., STAKER, H. Ensino Híbrido: uma Inovação Disruptiva? Uma introdução à teoria dos híbridos. 2013. Disponível em: https://porvir.org/wp-content/uploads/2014/08/PT_Is-K-12-blended-learning-disruptive-Final.pdf. Acesso em: 20 mai. 2021.

DATAREPORTAL. Digital 2021 - Brazil. 2021. Disponível em: https://datareportal.com/reports/digital-2021-brazil. Acesso em: 20 mai. 2021.

FEDOCE, R. S.; SQUIRRA, S. C. A Tecnologia Móvel e os Potenciais da Comunicação na Educação. Logos 35. Mediações Sonoras, v. 18, n. 2. 2011. 
FONSECA, A. G. M. F. Aprendizagem, mobilidade e convergência. mobile learning com celulares e smartphones. Revista Eletrônica do Programa de Pós-graduação em Mídia e Cotidiano, n. 2, p. 163-181. 2013.

GIANOTTO, D. E. P; DINIZ, R. E. S. Formação inicial de professores de Biologia: a metodologia colaborativa mediada pelo computador e a aprendizagem para a docência. Ciência e Educação, v. 16, n. 3, p. 631-648. 2010.

GIL, A. C. Como elaborar projetos de pesquisa. 6. ed. São Paulo: Atlas, 2017. $192 p$.

GOLDBACH, T.; EL-HANI, C. N. Entre Receitas, Programas e Códigos: Metáforas e Ideias Sobre Genes na Divulgação Científica e no Contexto Escolar. Alexandria - Revista de Educação em Ciência e Tecnologia, v. 1, n. 1, p. 153-189. 2008.

GOMES, C. C. Smartphone na Educação Básica: possibilidades e desafios no ensino de Biologia nas escolas da rede pública de São Mateus. 2019. 113 p. Dissertação (Ensino na Educação Básica) - Universidade Federal do Espírito Santo, 2019.

HODGES, C.; MOORE, S.; LOCKEE, B.; TRUST, T.; BOND, A. The Difference between emergency remote teaching and online learning. Educause Review, 2020. Disponível em: https://er.educause.edu/articles/2020/3/the-difference-between-emergency-remote-teaching-and-online-learning\#fn7. Acesso em: 08 jul. 2021.

KOEHLER, M. J.; MISHRA, P. What is technological pedagogical content knowledge? Contemporary Issues in Technology and Teacher Education, v. 9, n. 1, p. 60-70. 2009.

KRASILCHIK, M. Prática de ensino de biologia. 4. ed. São Paulo: Edusp. 2004. $197 p$.

LAGO, R. C.; BRITO, G. S. Educação Continuada em Tecnologias de Informação e Comunicação: Expectativas do Professor. In: WORKSHOP DE INFORMÁTICA NA ESCOLA, XXV., 2010, Brasília. Anais... Brasília: Sociedade Brasileira de Computação, 2010. p.1437-1440. 
LOPES, P. A.; PIMENTA, C. C. C. O uso do celular em sala de aula como ferramenta pedagógica: Benefícios e desafios. Revista Cadernos de Estudos e Pesquisa na Educação Básica, v. 3, n. 1, p. 52-66. 2017.

MAHAT, J., AYUB, A. F. M., LUAN, S. An assessment of students' mobile self-efficacy, readiness and personal innovativeness towards mobile learning in higher education in Malaysia. Procedia-Social and Behavioral Sciences, v. 64, p. 284290. 2012.

MERIJE, W. Mobimento - Educação e Comunicação Mobile. 1. ed. São Paulo: Peiropolis. 2012. 25p.

MORRIS, T. A. Anytime/Anywhere online learning: Does it remove barriers for adult learners? In: Kidd, T. (ed.). Online education and adult learning: New frontiers for teaching practices. New York: Information Science Reference. 2010, p. $115-123$.

MOURA, A. M. C. Apropriação do telemovel como ferramenta de mediação em mobile learning: estudos de caso em contexto educativo. 2010. 630p. Tese (Doutorado em Ciências da Educação - Área de Especialidade de Tecnologia Educativa) - Universidade do Minho, Braga. 2017.

NEVES, A.; Bündchen, M.; Lisboa, C. P. Cegueira botânica: é possível superá-la a partir da Educação? Ciência \& Educação, v. 25, n. 3. 2019.

OLIVEIRA, M. R. S. Mobile Learning e Ação Docente: o celular em sala de aula. In: Simpósio Internacional de Educação à distância e Encontro de pesquisadores em Educação à distância, 2014, São Carlos. Anais... São Carlos: UFSCar, 2014. p. 1-12.

ORLANDO, T. C. et al. Planejamento, montagem e aplicação de modelos didáticos para abordagem de biologia celular e molecular no ensino médio por 10 graduandos de ciências biológicas. Revista Brasileira de Ensino de Bioquímica e Biologia Molecular, n. 1, p.1-17. 2009.

PRENSKY, M. Digital Natives, Digital Immigrants. Part 2: Do They Really Think Different? On the Horizon, v. 9, n. 6, p. 1-6. 2001.

PRENSKY, M. Não me atrapalhe, mãe - Eu estou aprendendo! Como os videogames estão preparando nossos filhos para o sucesso no século XXI e como você pode ajudar! 1. ed. São Paulo: Phorte, 2010. 320p. 
QUEIROZ, R.; SILVA, F.; NASCIMENTO, A. Relato de experiência ensino remoto em tempos de pandemia: dificuldades e desafios em Goiás e Minas Gerais. In: Schütz et al (org). Escritos de Educação: perspectivas e tendências. v. 2 Cruz Alta: Ilustração, 2020. p. 217-225. Disponível em: https://www.academia.edu/44163542/A_PRODU\%C3\%87\%C3\%830_ACAD\%C3\%8AMICA_SOBRE_O_ENSINO_REMOTO_EMERGENCIAL_ERE_EM_MEIO_A_PANDEMIA_DA_COVID_19_PERSPECTIVAS_E_TEND\%C3\%8ANCIAS. Acesso em: 08 jul. 2021.

REIS, S. R.; SANTOS, F. A. S.; TAVARES, J. A. V. O uso das TICs em sala de aula: uma reflexão sobre o seu uso no Colégio Vinícius de Moraes/São Cristóvão. In: III Simpósio Educação e Comunicação: Info-inclusão, possibilidade de ensinar e aprender, 2012, Tiradentes. Anais... 2012, p. 205-228.

RIO GRANDE DO SUL. Lei 12.882, de 3 de Janeiro de 2008. Diário Oficial do Estado do Rio Grande do Sul, Rio Grande do Sul, 04 de janeiro de 2008, p.1

ROTHER, E. T. Revisão Sistemática X Revisão Narrativa. Acta Paulista de Enfermagem (Online). Editorial v.20, n.2, p. v-vi, 2007. Disponível em: https://www. scielo.br/pdf/ape/v20n2/en_a01v20n2.pdf. Acesso em: 21 jul. 2021.

SACCOL, A.; SCHLEMMER, E.; BARBOSA, J. M-learning e u-learning: novas perspectivas das aprendizagens móvel e ubíqua. 1. ed. São Paulo: Prentice Hall, 2010. 176p.

SANTA CATARINA. Lei 14.363, de 25 de Janeiro de 2008. Diário Oficial do Estado de Santa Catarina, Santa Catarina, 25 de Janeiro de 2008.

SANTAELLA, L. Desafios da ubiquidade para a educação. Especial: novas mídias e o ensino superior. Revista Ensino Superior - Unicamp, p. 19-28, 2013.

SANTOS, F. K. S. (org). Abrindo trilhas para os saberes. 1. ed. Fortaleza: SEDUC. 2009. 375p.

SANTOS, E; WEBER, A. Educação e cibercultura: aprendizagem ubíqua no currículo da disciplina didática. Revista Diálogo Educacional, v. 13, n. 38, p. 285303. 2013. 
SILVA, M. Internet na escola e inclusão. In: ALMEIDA, M. E. B.; MORAN, J. M. Integração das Tecnologias na Educação: salto para o futuro. Secretaria de Educação a Distância, Ministério da Educação 2005. p. 98-109. Disponível em: http://www.dominiopublico.gov.br/download/texto/me000701.pdf. Acesso em: 20 mai. 2021.

SILVA, B.; FALAVIGNA, G. Aprendizagem ubíqua na modalidade blearning: Estudo de caso do mestrado de Tecnologia Educativa da UMinho. In: Falavigna, G.; Silva, B. (org). Temas educacionais: Tecnologias, sustentabilidade, docência e recursos. Porto Alegre: EDIPUCRS, p. 11-37, 2016.

SILVEIRA, S.; BERTOLINI, C.; PARREIRA, F.; CUNHA, G.; BIGOLIN, N. O papel dos licenciados em computação no apoio ao ensino remoto em tempos de isolamento social devido à pandemia da COVID-19. In: Poisson (ed.) Série Educar - Prática Docente. v. 40. Belo Horizonte: Poisson, p. 35-42, 2020.

UNESCO - Organização das Nações Unidas para a Educação, a Ciência e a Cultura. Policy guidelines for mobile learning. Paris, FR: 2013. Disponível em: https://unesdoc.unesco.org/ark:/48223/pf0000219641. Acesso em: 20 mai. 2021.

VIVIAN, C. D.; PAULY, E. L. P. O uso do celular como recurso pedagógico na construção de um documentário intitulado: Fala sério! Colabor@ - Revista Digital da CVA - Ricesu, v. 7, n. 27. p. 20-32. 2012.

WANDERSEE, J. H.; SCHUSSLER, E. E. Preventing plant blindness. The American Biology Teacher, v. 61, n. 2, p. 284-286. 1999. 
doi $10.48209 / 978-65-89949-13-6$

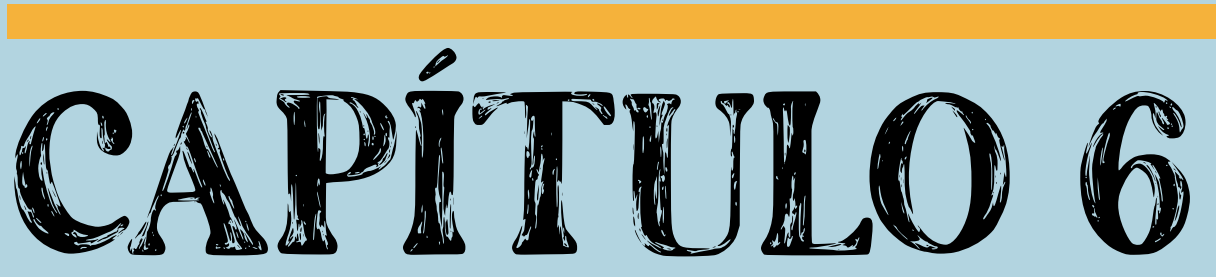

\section{O ENSINO DE BIOLOGIA EM TEMPOS DE PANDEMIA: UM LABORATÓRIO CASEIRO PARA A SIMULAÇÃO DA DIGESTÃO DE PROTEÍNAS}

Tiago Maretti Gonçalves ${ }^{1}$

$1 \quad$ O presente trabalho trata-se de um desdobramento de um artigo publicado pelo autor na Revista Educação Pública, CECIERJ, intitulado: "Ensinando Biologia em tempos de pandemia: um laboratório caseiro com materiais simples e de baixo custo para a simulação da digestão de proteínas" (GONÇALVES, 2021a). 


\section{INTRODUÇÃO}

A Fisiologia Humana é a área dentro da Biologia que se preocupa em estudar o funcionamento normal de um organismo e de suas partes, incluindo todos os processos físicos e químicos (SILVERTHORN, 2017). No ensino médio, na disciplina de Biologia, muitos alunos encaram a área de Fisiologia como complexa, uma vez que possui um vasto conteúdo e mecanismos que devem ser muito bem assimilados e compreendidos, podendo desmotivar a aprendizagem do aluno. Assim sendo, a busca por metodologias alternativas de ensino, aliadas às aulas teóricas, podem ser de grande importância para o objetivo de facilitar o processo de ensino e da aprendizagem (GONÇALVES, 2021b), e uma delas é o uso de aulas práticas (experimentação).

$\mathrm{Na}$ atualidade, a experimentação científica passou a ser uma grande aliada no ensino de Ciências e Biologia e possui grande impacto e relevância dentro da sala de aula uma vez que, segundo Borges (2002), seus objetivos estão relacionados com: verificar/comprovar leis e teorias científicas; promover o ensino do método científico; facilitar a aprendizagem e compreensão de conceitos; e ensinar habilidades práticas. Nesse sentido, segundo discussões de French (2009), a experimentação entra como um componente determinante para o fornecimento de uma base confiável e legítima para o conhecimento científico. Outro ponto importante que deve ser ressaltado é a arte da observação e, segundo French (2009), esse ato não é um simples abrir de olhos, mas sim um processo intervencionista sobre aquilo que se estuda, que se pesquisa. Assim, de acordo com Pagel, Campos e Batitucci (2015, p. 14):

As aulas práticas, segundo a literatura pertinente, podem ajudar no processo de interação, na apropriação e no desenvolvimento de conceitos científicos por parte dos sujeitos. Permitem que os estudantes aprendam a abordar objetivamente o seu mundo e a desenvolver saídas para situações que envolvam muitas variáveis.

As atividades experimentais no ensino de Biologia, constitui uma metodologia de grande impacto no aprendizado dos discentes, no entanto, no contexto atual, o uso de aulas práticas ainda é muito restrito no âmbito escolar. Um dos motivos para a baixa frequência dessa abordagem no ensino de Biologia é a escassez de 
recursos financeiros para a construção de laboratórios físicos e/ou a incapacidade de sua manutenção, por estes possuírem materiais de alto custo, inviabilizando assim a sua prática.

Orlando et al. (2009) destacam que no nosso país a existência de laboratórios de Biologia nas escolas públicas ainda é pouco comum. No entanto, esse espaço físico é mais comumente disponível aos alunos em escolas particulares de alto nível. Retomando um contexto histórico, na década de 1950, após a criação do Instituto Brasileiro de Ciências e Cultura (Ibecc), surge um projeto nacional em defesa da experimentação, que consistiu na criação de materiais didáticos que apoiavam e disseminavam a ideia da experimentação científica a alunos e professores (MARANDINO; SELLES; FERREIRA, 2009). Segundo Montalvão Neto (2013), na década de 1970 houve um movimento expressivo de retomada do tecnicismo, que supervalorizou as experimentações científicas no âmbito escolar, porém, desconsiderando as realidades escolares brasileiras, algo que podemos dizer que ainda é muito familiar ao considerarmos as diretrizes educacionais atuais.

Ao analisar a Base Nacional Comum Curricular (BNCC) (BRASIL, 2021, p. 550) é relatado que:

Os processos e práticas de investigação merecem também destaque especial nessa área. Portanto, a dimensão investigativa das Ciências da Natureza deve ser enfatizada no Ensino Médio, aproximando os estudantes dos procedimentos e instrumentos de investigação, tais como: identificar problemas, formular questões, identificar informações ou variáveis relevantes, propor e testar hipóteses, elaborar argumentos e explicações, escolher e utilizar instrumentos de medida, planejar e realizar atividades experimentais e pesquisas de campo, relatar, avaliar e comunicar conclusões e desenvolver ações de intervenção, a partir da análise de dados e informações sobre as temáticas da área.

Neste sentido, a BNCC reitera a necessidade de que os discentes devem possuir o contato com a experimentação científica, como atividades laboratoriais, atividades de campo. No entanto, a base é carente em termos de enfatizar quais caminhos o aluno deve percorrer para atingir tais procedimentos. Assim, Jardim et al. (2019) discutem que a educação brasileira está há décadas em busca de desenvolver o conhecimento científico. Todavia, percebe-se que cada vez 
mais as escolas públicas perdem o seu espaço, visto que seus laboratórios são sucateados e estão longe de chegar aos objetivos propostos pelos documentos orientadores da educação.

Outro aspecto que afeta o uso das aulas práticas no cotidiano escolar é o desinteresse dos alunos, principalmente pela presença de um número excessivo destes dentro da classe e, somado a isso, ocorre a escassez de material disponível para uso no laboratório. Não obstante, podemos destacar que, segundo Interaminense (2019), a própria formação dos professores pode ser um entrave para a popularização do uso da experimentação cientifica dentro de sala de aula, visto que, muitas vezes, eles não tiveram um preparo acadêmico para esse tipo de atividade ou não recebem formação continuada em relação às inovações tecnológicas disponíveis.

$\mathrm{Na}$ atualidade, as aulas seguem um modelo virtual ou semipresencial de ensino, devido a pandemia do novo coronavírus (Sars-CoV-2), causador da Covid-19. Nesse sentido, as atividades de ensino realizadas em meio à pandemia são denominadas como Ensino Remoto Emergencial ou Ensino Remoto de Emergência (ERE). Segundo Hodges et al. (2020, p. 6):

O Ensino Remoto de Emergência (ERT) é uma mudança temporária para um modo de ensino alternativo devido a circunstâncias de crise. Envolve o uso de soluções de ensino totalmente remotas para o ensino que, de outra forma, seriam ministradas presencialmente ou como cursos híbridos, e, que, retornarão a esses formatos assim que a crise ou emergência diminuir ou acabar.

Considerando os percalços do ERE e a necessidade de proposição de práticas que venham a amenizar as dificuldades de ensino em meio ao atual contexto de pandemia, o objetivo principal deste trabalho é refletir sobre as potencialidades da experimentação, a partir de uma proposta de uma aula prática que visa fomentar a aprendizagem de tópicos de Fisiologia Animal (digestão de proteínas) e a qual intenciona-se que seja aplicada na disciplina de Biologia, mais especificamente com alunos do segundo ano ensino médio. 


\section{ASPECTOS METODOLÓgICOS E DESENVOLVIMENTO DO ESTUDO}

A atividade prática proposta exibe resultados sob uma ótica qualitativa, tendo como suporte metodológico a obra de Pereira et al. (2018). No que tange ao protocolo experimental, essa atividade prática foi, em partes, baseada no experimento publicado por Rossi-Rodrigues et al. (2012). No entanto, a atividade sofreu modificações e inclusões (como é o caso, por exemplo, do sachê de enzimas e o amaciante de carne), incrementando as discussões e problematizações que podem ser realizadas entre o(s) professor(es) e o(s) aluno(s). Além disso, a metodologia apresentada neste trabalho permite ao estudante efetuá-la em sua própria casa, uma vez que as aulas têm seguido o modelo virtual de ensino decorrente da pandemia do novo coronavírus.

Nesse experimento, os alunos irão utilizar materiais simples e de baixo custo para simular a digestão de proteínas, intencionando que compreendam o mecanismo de ação das enzimas bromelina (proveniente do abacaxi), papaína (do mamão verde), sachê de enzimas digestivas (adquirido comercialmente) e do amaciante de carne na degradação da proteína de colágeno existente na gelatina em pó. Essa prática, poderá ser realizada em casa pelos próprios alunos, que, ao final, poderão responder a um questionário, sendo esse questionário posteriormente enviado ao professor para correções e discussões futuras. Assim, ao vivenciarem a atividade aqui proposta, os alunos poderão desenvolver as suas habilidades cotidianas a partir de práticas científicas. Além disso, a nosso ver, essa atividade poderá permitir a formulação de hipóteses e a explanação dos resultados obtidos pelos sujeitos que as realizem.

\section{Materiais utilizados na atividade prática:}

$\mathrm{Na}$ atividade prática proposta, são utilizados materiais simples e de baixo custo, como apresentados seguir:

- 1 mamão verde;

- 1 abacaxi verde; 
- Gelatina em pó em embalagem de 20 g;

- Como opção pode ser utilizado a clara do ovo ao invés da gelatina;

- 1 sachê de complexo de enzimas digestivas em pó (adquirido em farmácias ou em casas de produtos naturais);

- 1 amaciante de carne (adquirido em supermercados);

- 1 liquidificador ou processador;

- 1 peneira para filtrar o suco das frutas;

- Fogão;

- 5 seringas graduadas com $5 \mathrm{ml}$ (facilmente adquiridas em farmácias);

- 1 colher de chá;

- Faca sem ponta;

- 5 potes pequenos de $150 \mathrm{ml}$ cada;

- 5 copos de café com capacidade de $50 \mathrm{ml}$ cada;

- Frasco de $500 \mathrm{ml}$ e 1 caneta de retroprojetor, marca texto ou canetinha.

- 3 bastões de massa de modelar com cores diferentes para representação da proteína de colágeno.

\section{Procedimentos:}

Aseguir descrevemos os procedimentos a serem adotados para a realização da atividade proposta.

\section{a) Preparo da gelatina:}

A gelatina deve ser preparada dissolvendo-a, conforme consta nas instruções do fabricante, sendo assim fervida no fogão. Aqui, como usa-se o fogão, é importante pedir auxílio para um adulto para evitar possíveis acidentes domésticos. Depois de pronta, dissolvida e preparada, a gelatina deverá ser armazenada em um frasco de vidro de $500 \mathrm{ml}$. 
b) Preparo e obtenção dos sucos das frutas:

Para obter o suco do mamão verde é necessário cortá-lo em pequenos pedaços. Nessa etapa, devemos utilizar uma faca sem pontas para picá-lo. Vale ressaltar que, no caso do mamão verde, devemos cortá-lo sem retirar a sua casca (Figura 1a). A explicação para manter a casca do mamão é a grande presença da enzima papaína, que mais a frente iremos discutir o seu importante papel nessa aula prática. Após cortar o mamão com a casca em pequenos pedaços, esses pedaços deverão ser batidos por alguns minutos no liquidificador com meio copo de água para permitir uma maior solubilidade do suco. Após esse processo, devemos peneirá-lo com uma pequena peneira de cozinha, para retirada dos grumos e pedaços das frutas, obtendo-se assim um líquido mais filtrado (figura 1b). O suco de mamão obtido deverá ser armazenado em um pote de plástico de $150 \mathrm{ml}$ (figura 1c).

Figura 1 - Processamento do mamão para obtenção do suco a) Mamão verde picado com casca; b) suco do mamão processado no liquidificador e peneirado e c) suco filtrado de mamão acondicionado em pote de plástico de $150 \mathrm{ml}$.
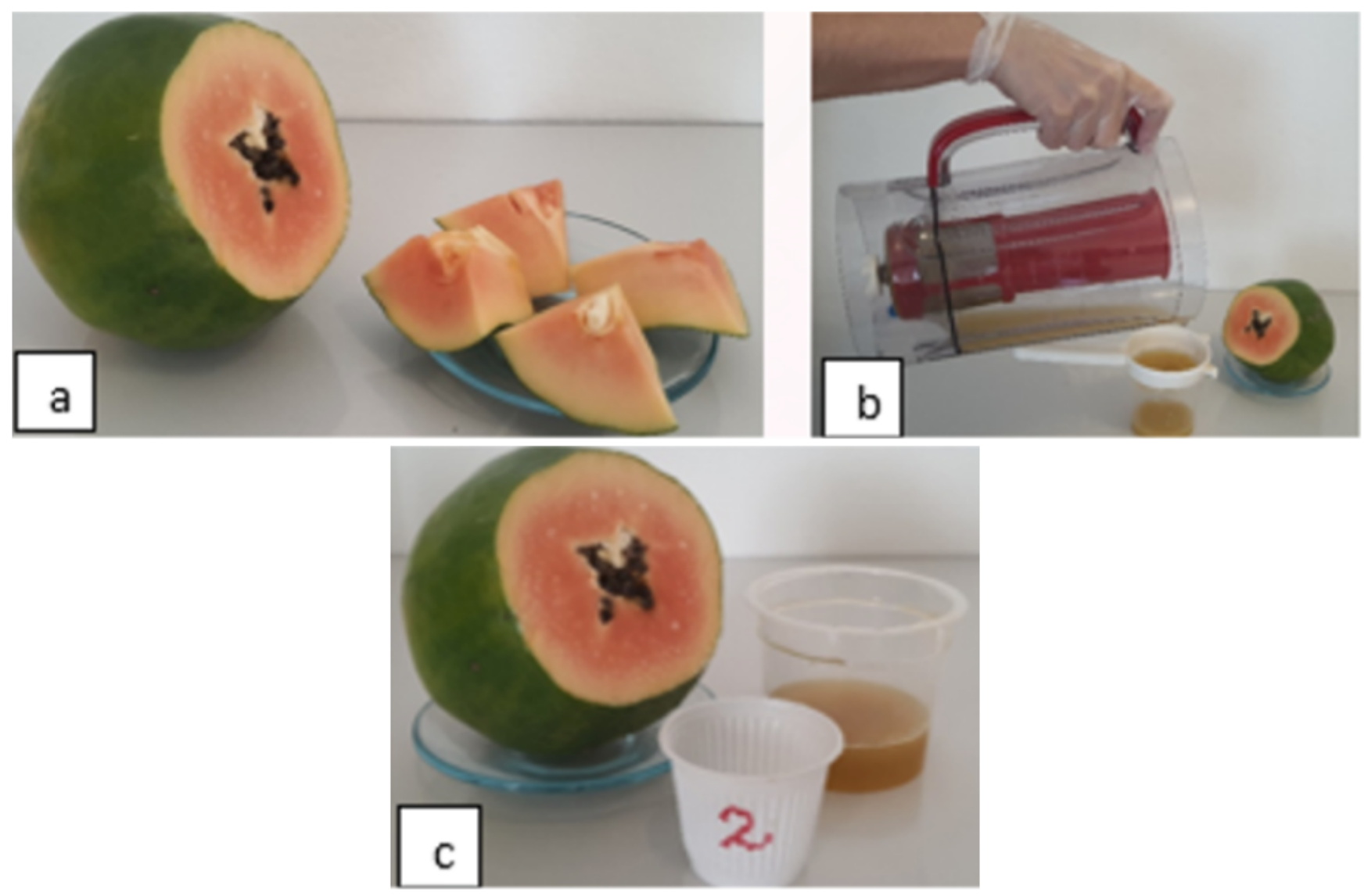

Fonte: Autor, 2021. 
Para o abacaxi, a primeira etapa é retirar sua casca, uma vez que ela é muito rígida (figura 2a). Nessa etapa do experimento devemos ter um cuidado redobrado, pois como a casca é muito resistente e pode ocorrer acidentes. Como sugestão, sugere-se que se peça a um adulto para realizar essa tarefa utilizando uma faca mais afiada. Depois de cortada a fruta em pequenos pedaços, esses pedaços deverão ser coados (figura $2 b$ ) e o seu suco armazenado em um pote de $150 \mathrm{ml}$ (figura 2c).

Figura 2 - Processamento do abacaxi para obtenção do suco a) Abacaxi picado sem casca; b) Suco do abacaxi processado no liquidificador e peneirado e c) suco filtrado de abacaxi acondicionado em pote de plástico de $150 \mathrm{ml}$.
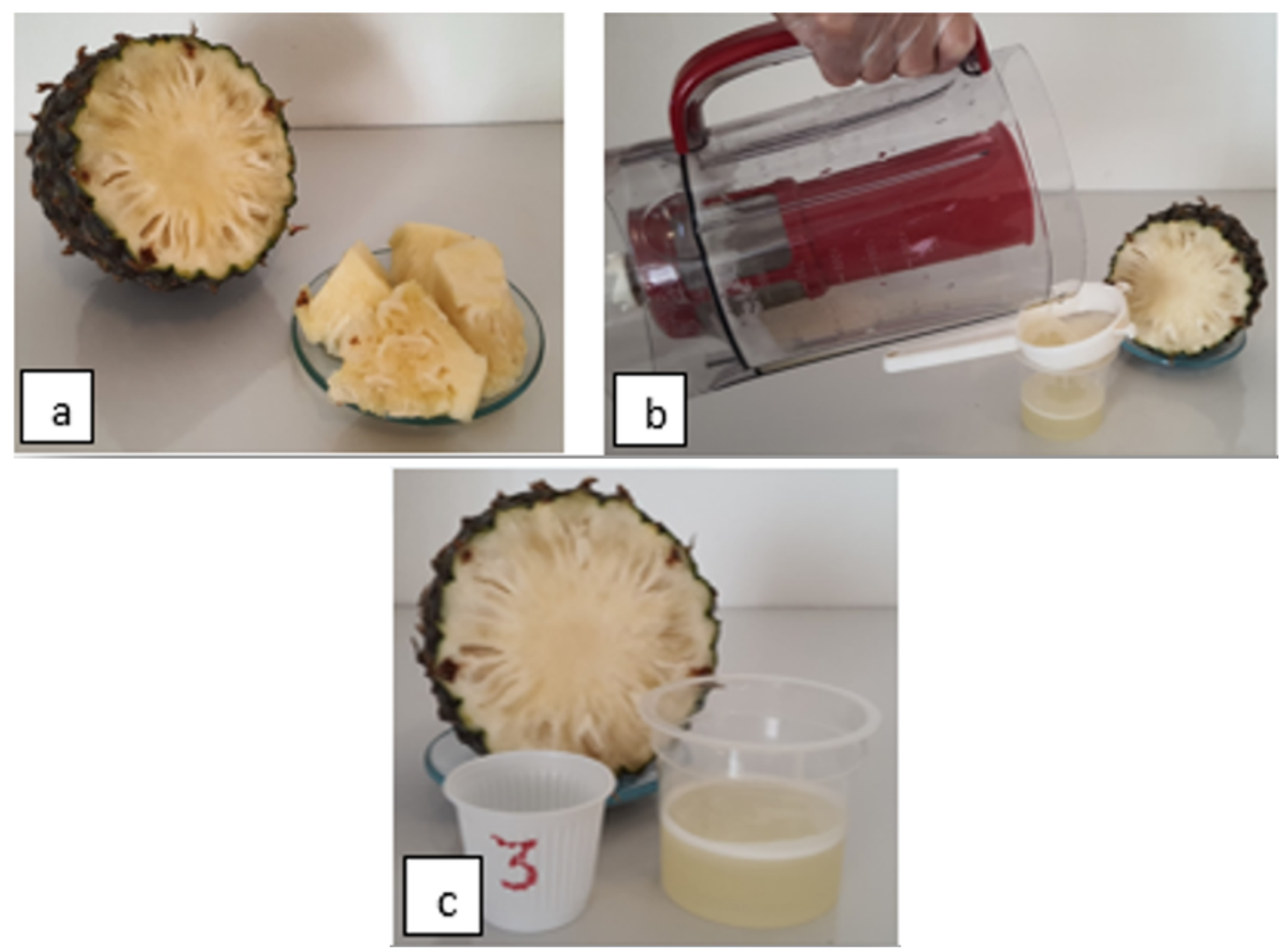

Fonte: Autor, 2021.

c) Preparo e preenchimento dos copos de café:

Inicialmente, com o auxílio de uma caneta de retroprojetor, enumere de 1 a 5 os copos de café de $50 \mathrm{ml}$. Na próxima etapa, o aluno deverá preencher os 
copos conforme as informações constantes no Quadro 1, dando continuidade ao experimento.

Quadro 1. Preenchimento dos copos para a realização da atividade prática.

\begin{tabular}{|c|c|}
\hline Legenda & Conteúdo no interior dos copos \\
\hline Copo 1 (Controle) & Água $(2 \mathrm{ml})$, com a adição de $4 \mathrm{ml}$ de gelatina líquida. \\
\hline Copo 2 & Mamão (2 ml) e gelatina líquida ( $4 \mathrm{ml})$. \\
\hline Copo 3 & Abacaxi $(2 \mathrm{ml})$ e gelatina líquida $(4 \mathrm{ml})$. \\
\hline Copo 4 & $\begin{array}{c}\text { Conteúdo de } 1 \text { sachê de enzimas digestivas em pó e } \\
\text { gelatina líquida }(4 \mathrm{ml}) .\end{array}$ \\
\hline Copo 5 & $\begin{array}{c}\text { Uma colher de chá do amaciante de carne em pó e } \\
\text { gelatina líquida }(4 \mathrm{ml}) .\end{array}$ \\
\hline
\end{tabular}

Fonte: Quadro elaborado com base em Rossi-Rodrigues et al. (2012), com modificações do autor.

A gelatina líquida deverá ser colocada em cada um dos copos por meio do uso de uma seringa de plástico de $5 \mathrm{ml}$, que pode ser facilmente adquirida em farmácias. Vale a pena ressaltarmos que, para a adição da gelatina fervida nos copos, é necessário esperar alguns minutos até que a gelatina fervida possa esfriar, evitando-se assim acidentes.

A etapa final do experimento, é colocar os copos preparados na geladeira e esperar que o copo número 1 (controle do experimento) endureça. Essa etapa pode levar até 15 minutos. Após fazer isso, todos os copos devem ser retirados da geladeira para análise e registro dos resultados. 


\section{RESULTADOS E DISCUSSÃO}

Como explicitado anteriormente, o copo número 1 é o controle (padrão) do experimento. Assim, espera-se que o seu conteúdo interno tenha endurecido normalmente (figura 3).

Figura 3 - Copo 1 (controle) com água + gelatina endurecida.

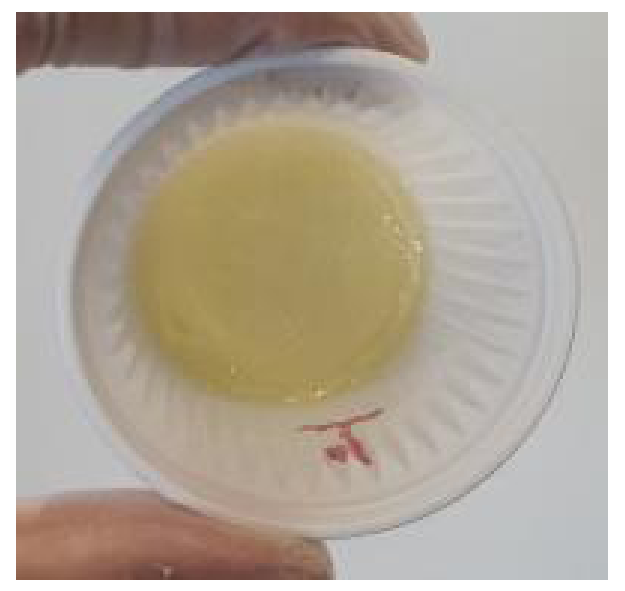

Fonte: Autor, 2021.

Nessa etapa do experimento o professor pode discutir com os alunos o porquê de a gelatina endurecer. A resposta para essa pergunta está no fato da gelatina conter uma proteína denominada colágeno que possui uma longa sequência de aminoácidos. Sua estrutura molecular de aminoácidos é formada por 3 cadeias polipeptídicas (3 alfa-hélices), denominada de tropocolágeno, que podem ser unidas por meio de ligações não covalentes (ligações hidrofóbicas, ligações de hidrogênio, pontes dissulfeto e ligações eletrostáticas), que estabilizam a estrutura terciária da proteína. Assim, ao adicionarmos a água e ferver a gelatina (colágeno), as ligações químicas entre essas cadeias irão se romper (desnaturação), dissolvendo-se em água. Agora, ao colocarmos na geladeira, a temperatura mais baixa irá fazer com que as cadeias voltem a se unir (renaturação), formando a estrutura tripla novamente.

Para facilitar a contextualização e a discussão dessa parte do experimento, o professor poderá utilizar de artifícios físicos, como, por exemplo, o uso de três bastões coloridos de massa de modelar. Cada bastão modelado, vai simular cada uma das cadeias polipeptídicas que formam a proteína de colágeno (alfa- 
hélices). Para isso, o professor precisará retorcer esses bastões algumas vezes, mostrando aos alunos que suas cadeias ficam unidas umas às outras, justamente por meio de ligações químicas (citadas anteriormente) (Figura 4a). O calor (fervura) irá propiciar a perturbação (desnaturação) dessas ligações químicas, ocasionando a quebra das cadeias da proteína de colágeno, e a gelatina se torna viscosa (líquida). Agora, com o calor, o professor poderá mostrar aos alunos que as cadeias que formam a proteína de colágeno (representado por bastões coloridos) não estarão mais unidas (separadas, relaxadas), já que suas ligações químicas foram desfeitas (Figura 4b). Ao colocarmos na geladeira em baixas temperaturas, a gelatina e a água se solidificarão, uma vez que as ligações químicas do colágeno da gelatina irão se recompor (renaturação), voltando ao aspecto inicial dos bastões de massa de modelar retorcido (3 alfa-hélices, da molécula de tropocolágeno) (Figura 4a).

Figura 4 - Demonstração da molécula da proteína de colágeno (tropocolágeno) da gelatina. a) estado da proteína normal (3 alfa-hélices unidas e retorcidas). b) Aspecto das cadeias da proteína de colágeno separadas (desnaturadas) em detrimento ao calor (fervura).

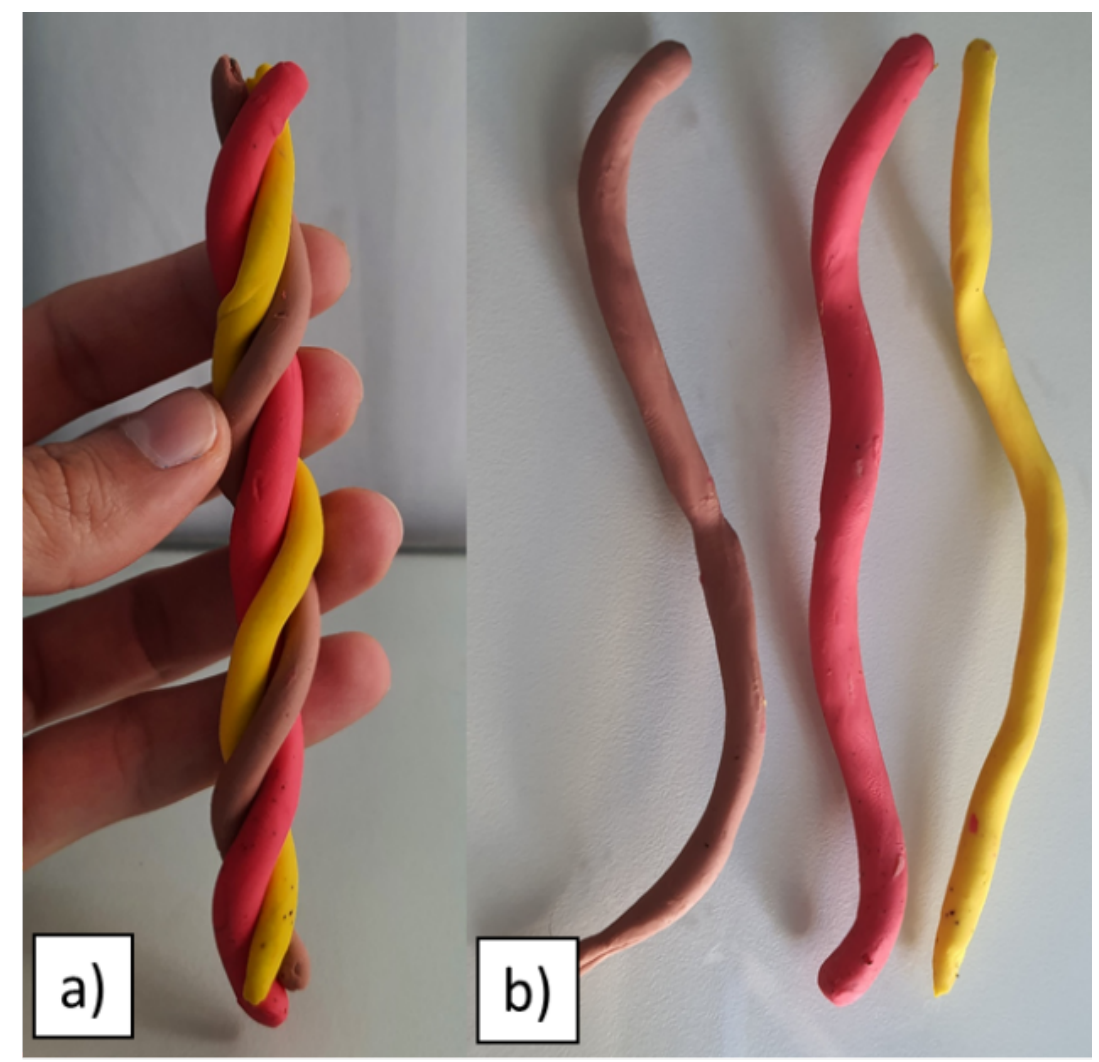

Fonte: Autor, 2021. 
No copo número 2, que contém suco de mamão, é esperado que a gelatina não tenha endurecido (figura 5a). O mesmo poderá ser observado no copo 3 , com extrato de abacaxi a gelatina, que também se espera que não tenha endurecido (figura 5b).

Figura 5 - Resultados do experimento a) Copo 2: gelatina degradada pela enzima papaína presente no extrato de mamão b) Copo 3: Gelatina degradada pela enzima bromelina presente no extrato de abacaxi c) Copo 4: gelatina degradada pelo sachê das enzimas digestivas em pó e d) Copo 5: degradação da gelatina pelo amaciante de carne. Observar a aparência de um líquido viscoso.
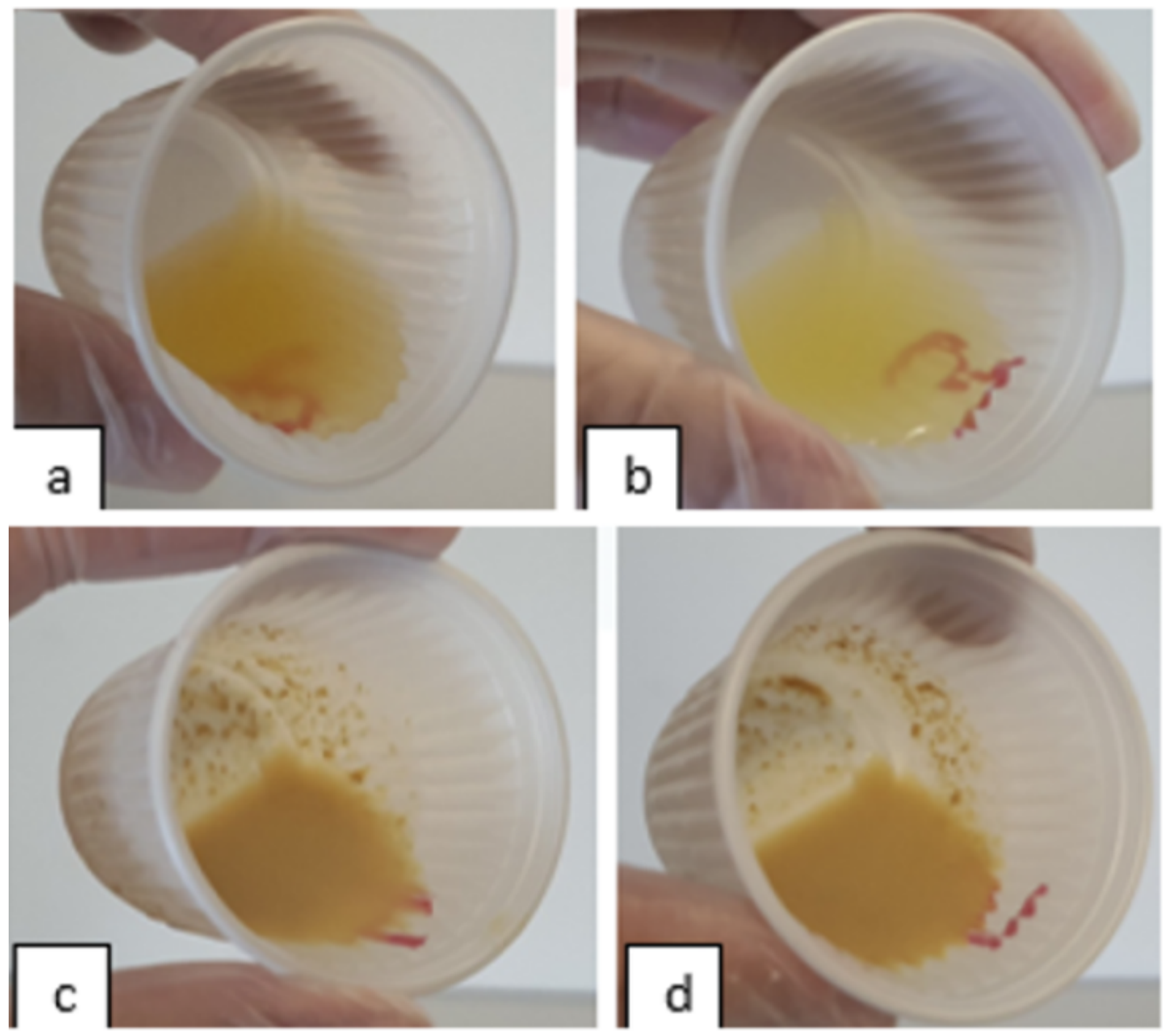

Fonte: Autor, 2021. 
Nessa etapa do experimento indica-se que o professor chame a atenção dos alunos e questione-os o porquê de a gelatina não endurecer nesses copos. Para o copo número 2, a gelatina não endurecerá devido ao fato de o suco de mamão conter uma enzima, a papaína, que possui uma atividade proteolítica, ou seja, essa enzima atua clivando a estrutura proteica do colágeno, fazendo com que ela não endureça, e fique aquosa (figura 5a). Sugere-se que seja explicado aos alunos que a papaína é uma enzima presente na casca do mamão, e que, além de possuir atividade de degradação de proteínas (proteolítica), possui ação bactericida e anti-inflamatória, podendo até mesmo auxiliar na cicatrização de ferimentos (Tavares et al. 2019).

No copo 3 espera-se que a gelatina também não tenha endurecido (figura 4b), e isso está relacionado com a presença da enzima bromelina presente no abacaxi. Essa enzima degrada o colágeno da gelatina, não deixando ela se solidificar. Aqui também poderá ocorrer algo similar ao que mencionamos sobre o copo 2: é esperado que a atividade proteolítica da enzima clive a estrutura molecular do colágeno, ficando uma solução aquosa.

No copo 4 será utilizado um sachê composto por várias enzimas digestivas, entre elas estão: lipase, lactase, amilase, bromelina e protease. No copo 5, será utilizado o amaciante de carne, que possui em seu conteúdo a papaína, a bromelina e a ficina, provenientes do figo. Considerando essas condições, apontamos que tanto o sachê como o amaciante possuem efetiva degradação de proteínas, pois as enzimas ali presentes quebram as proteínas em peptídeos menores. No nosso caso, em que usamos a gelatina, espera-se que o colágeno seja clivado em peptídeos bem pequenos, sendo esperado assim que seja visualizado um líquido viscoso em ambos os copos. (figura 5 c e $5 d$ ).

A aula prática proposta é recomendada para ser ministrada aos alunos após a aula teórica de Fisiologia Animal, em que se trabalha o Sistema Digestório humano na disciplina de Biologia no ensino médio. Nesse âmbito, podemos comentar e discutir com os alunos que na boca ocorre a primeira ação enzimática, a partir das glândulas salivares (ptialina) no amido, quebrando esse amido em unidades de glicose para que depois possa ocorrer a sua absorção pelo corpo 
humano. Já os alimentos que contém proteínas são degradados no estômago com a ação de pepsinas, que, com o auxílio do suco gástrico, clivam as cadeias das proteínas em aminoácidos menores.

No intestino delgado, apesar de ocorrer grande parte da absorção dos nutrientes, também temos a ocorrência de enzimas degradando proteínas, como é o caso da tripsina. Assim, nesta aula prática, o papel das enzimas bromelina do abacaxi e papaína do mamão possuem correlação com as enzimas presentes no suco gástrico do estômago, que degradam as proteínas, processando os alimentos em partículas menores prontas para então ocorrer a absorção no intestino por meio das vilosidades e microvilosidades. Então, quando se ingere uma dieta rica em proteínas, é recomendável que se consuma alimentos que possam auxiliar na digestão, como, por exemplo, fatias de abacaxi ou de mamão.

No intuito de potencializar e avaliar as aprendizagens, a seguir estão dispostas algumas questões que poderão ser enviadas aos alunos após a realização das atividades, bem como as suas soluções esperadas.

\section{Questionário proposto aos alunos para enriquecer as aprendizagens:}

1. Descreva detalhadamente o que ocorreu em cada um dos copos. Elabore uma hipótese para explicar os resultados em cada um deles.

2. Você imagina que as frutas utilizadas neste experimento poderiam auxiliar no processo de digestão? E no processo de amaciamento das fibras da carne? Explique sua resposta.

3. Qual é a composição química do sachê enzimático utilizado por você (observe no verso da embalagem)? Ele possui o mesmo papel da bromelina e papaína, encontradas respectivamente no abacaxi e no mamão? Explique a sua resposta.

4. Em quais partes do sistema digestório ocorre a degradação (digestão) das proteínas? Indique as partes e as principais enzimas digestivas atuantes no processo. 
5. Suponha que você possua uma xícara com leite integral, na qual adiciona cerca de 20 gotas de limão. A partir de alguns minutos, o que acontecerá? Descreva. Esse experimento possui relação com a aula prática de degradação da gelatina pelas enzimas proteolíticas contidas nas frutas de mamão, papaína, sachê enzimático e amaciante de carne? Justifique a sua resposta com base nos resultados obtidos.

\section{Respostas esperadas do questionário proposto:}

1. Descrição do que aconteceu em cada copo:

Copo 1: gelatina endurecida;

Copo 2: gelatina degradada pela enzima papaína presente no extrato de mamão;

Copo 3: Gelatina degradada pela enzima bromelina presente no extrato de abacaxi;

Copo 4: gelatina degradada pelo sachê das enzimas digestivas em pó;

Copo 5: degradação da gelatina pelo amaciante de carne;

\section{Provável explicação para cada acontecimento:}

O copo 1 é o nosso controle. Nele, a gelatina irá endurecer sem nenhuma interferência, como é o esperado. No copo 2, a gelatina ficará aquosa e não irá endurecer. Esse fenômeno pode ser explicado pela presença de enzimas (papaína), presentes no extrato do mamão, que quebram as proteínas da gelatina (colágeno), deixando-a amolecida. No copo 3, pela adição do extrato de abacaxi, a gelatina provavelmente não endureceu, devido ao fato das enzimas presentes no abacaxi (bromelina) degradarem a gelatina. Nos copos 4 e 5, o sachê de enzimas e o amaciante de carne, respectivamente, possuem enzimas que quebram as proteínas, do colágeno na gelatina. Poderemos, então, observar a formação de um líquido de aparência viscosa. 
2. Sim, tanto as frutas quanto o amaciante de carnes, utilizados na aula prática, podem auxiliar no processo da digestão, pois eles possuem enzimas capazes de digerir proteínas, tornando-as peptídeos menores e facilitando a sua digestão e, por conseguinte, a sua absorção pelo organismo.

3. Essa pergunta pode ter várias respostas, a depender do sachê de enzimas que o aluno adquiriu para fazer a aula prática. No entanto, o sachê de enzimas, que rotineiramente é vendido em farmácias e em casas de produtos naturais, possui em sua composição uma série de enzimas que atuam da digestão de proteínas como a bromelina e outras proteases, além de outras enzimas capazes de quebrar o amido (amilase) e lipídios (lipases). O sachê de enzimas possui o mesmo papel das enzimas papaína e bromelina, observadas no experimento, pois ele possui como função a digestão (degradação) de proteínas.

4. A degradação (digestão) das proteínas ocorre inicialmente no estômago. Como nessa parte do organismo o pH do meio é ácido, em detrimento do ácido clorídrico, a enzima pepsina irá iniciar a quebra das ligações existentes entre os aminoácidos (ligações peptídicas), transformando-as em pequenas cadeias peptídicas. Quando o alimento chega no intestino delgado (a porção chamada duodeno), ocorre a liberação da enzima enteroquinase, que irá ativar outras enzimas como a tripsina. A tripsina, então, poderá desencadear uma cascata de reações ativando outras enzimas para ocorrer a digestão de mais proteínas.

5. Ao pingar 20 gotas de limão no leite integral, a partir de alguns minutos, ele fica coalhado, exibindo uma parte líquida transparente em sua extremidade. Esse experimento se relaciona com a aula prática da degradação das proteínas. No entanto, o que é alterado é o pH do meio devido ao fato do limão ser muito ácido (presença de ácido cítrico), o que leva à desnaturação (degradação) das proteínas do leite (formação de coalho).

\section{CONSIDERAÇÕES FINAIS}

Este trabalho teve como objetivo a proposta de uma atividade de cunho experimental, com resultados qualitativos, no intuito de facilitar a aprendizagem dos alunos no tópico de Fisiologia Animal (digestão de proteínas), utilizando materiais simples e de baixo custo. Com base na sugestão experimental aqui proposta 
para o ensino médio, acreditamos que a abordagem de aulas práticas pode ser de grande importância, pois facilita o processo de ensino e de aprendizagem dos alunos, transpondo, na prática, o que foi aprendido na aula teórica. Além disso, acreditamos que a atividade experimental contribui para despertar o lado criativo e científico dos discentes, potencializando a ótica de experimentação em ciências.

Como possíveis desdobramentos dessa proposta, apontamos que o professor poderá propor aos alunos outros experimentos, utilizando outros tipos de frutas com capacidade proteolítica, como, por exemplo, o Kiwi, que possui a enzima natural actinidina. Por fim, apontamos que demais estudos que tragam propostas de atividades com materiais de fácil acesso e baixo custo se fazem necessários no ensino de Ciências/Biologia, visto que, a partir da experimentação, há muitas possibilidades de abordar diferentes temáticas, seja em sala de aula ou em aulas remotas.

\section{REFERÊNCIAS}

BORGES, T. Novos rumos para o laboratório escolar de ciências. Caderno Brasileiro de Ensino da Física, v. 19, n. 3, p. 291-313, 2002.

BRASIL. Ministério da Educação. Secretaria de Educação. Base Nacional Comum Curricular. Brasília, 2021. 600p.

FRENCH, S. Ciência: conceitos-chave em filosofia. Artmed Editora, 2009.

GONÇALVES, T. M. Ensinando Biologia em tempos de pandemia: um laboratório caseiro com materiais simples e de baixo custo para a simulação da digestão de proteínas. Revista Educação Pública, v. 21, n. 5, 2021 a.

GONÇALVES, T. M. A guerra imunológica das células contra os patógenos: a proposta de um modelo didático tridimensional de baixo custo para simulação da resposta imune celular mediada por linfócitos T CD8 ${ }^{+}$. Brazilian Journal of Development, v.7, n.1, p. 4854-4860, 2021 b.

HODGES, C.; TRUST, T.; MOORE, S.; BOND, A.; LOCKEE, B. Diferenças entre o aprendizado online e o ensino remoto de emergência. Revista da Escola, Professor, Educação e Tecnologia. v. 2, p. 1-12, 2020. 
INTERAMINENSE, B. K. S. A Importância das aulas práticas no ensino da Biologia: Uma Metodologia Interativa. Id on Line Revista Multidisciplinar e de Psicologia, v. 13, n. 45, s. 1, p. 342-354, 2019.

JARDIM, A. L. S.; DE CARVALHO, A. V.; COSTA, M. T.; CASTRO, L. R. B.; PESSANO, E. F. C. O ensino de ciências a partir de aulas práticas: uma conversa com discentes de ciências da natureza. Educação Ambiental em Ação. v. 2, p. 1-6, 2019.

MARANDINO, M.; SELLES, S. E.; FERREIRA, M. S. Ensino de Biologia: histórias e práticas em diferentes espaços educativos. Cortez editora, 2009. 215p.

MONTALVÃO NETO, A. L. Os conteúdos de genética nos livros didáticos de Biologia entre as décadas de 1970 e 1990. 67 f. Trabalho de Conclusão de Curso (Licenciatura em Ciências Biológicas). Universidade Federal de São Carlos, Sorocaba, 2013.

ORLANDO, T.C.; LIMA, A.R.; SILVA, A.M.; FUSISAKI, C.; RAMOS, C.L.; MACHADO, D.; FERNANDES, F.F.; LORENZI, J.C.C.; LIMA, M.A.; GARDIM, S.; BARBOSA, V.C.; TREZ, T.A. Planejamento, montagem e aplicação de modelos didáticos para abordagem de Biologia Celular e Molecular no Ensino Médio por graduandos de Ciências Biológicas. Revista Brasileira de Ensino de Bioquímica e Biologia Molecular, v. 10, p. p.1-17, 2009.

PAGEL, U. R.; CAMPOS, L. M.; BATITUCCI, M. C. P. Metodologias e práticas docentes: uma reflexão acerca da contribuição das aulas práticas no processo de ensino-aprendizagem de biologia. Experiências em Ensino de Ciências. v.10, n. 2, 14-25. 2015.

PEREIRA A. S.; SHITSUKA, D. M.; PARREIRA, F. J.; SHITSUKA, R. Metodologia da pesquisa científica. Santa Maria. Ed. UAB/NTE/UFSM. 2018.

ROSSI-RODRIGUES, B. C.; HELENO, M. G.; SANTOS, R. V.; MARCHINI, G. L.; DIAS, F. M. P. P.; CHIKUCHI, H. A.; GALEMBECK, E. Atividade enzimática de extratos vegetais na degradação de gelatina. In: ROSSI-RODRIGUES, B. C.; GALEMBECK, E. Biologia: aulas práticas. Campinas: Ed. UNICAMP, 2012. p. 25-28. 
SILVERTHORN, D. U.; Fisiologia Humana: uma abordagem integrada. $7^{\mathrm{a}}$ edição. Porto Alegre. Artmed, 2017. 963p.

TAVARES, A. S.; NASCIMENTO, D. C.; MARQUES, G. S.; SOUZA, N. V. D. O.; ALMEIDA, P. F.; SILVA, P. A. S.; SANTOS, D. M.; SAVIN, R. C. S. Aplicação de papaína em pó em deiscência de ferida operatória infectada. In: SOMBRA, I. C.N. Semiologia de Enfermagem. Ponta Grossa: Editora Atena, 2019. p. 261-266. 
doi 10.48209/978-65-89949-13-7

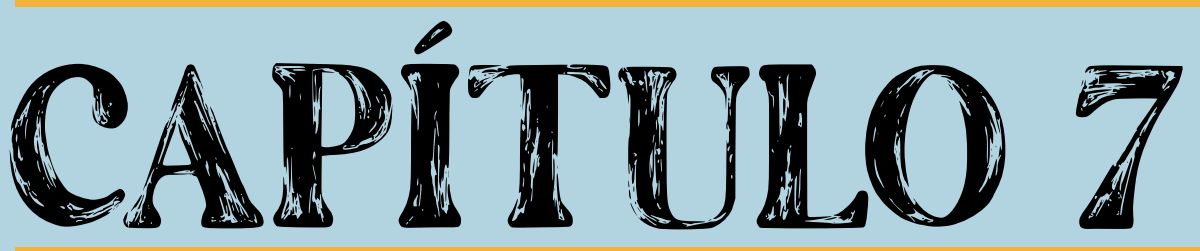

\section{REALIDADE VIRTUAL: UMA ALTERNATIVA TECNOLÓGICA PARA O ENSINO DE FÍSICA}

Érica Romão da Silva Lima Haroldo Reis Alves de Macêdo 


\section{INTRODUÇÃO}

O atual momento que o mundo está passando com a pandemia da covid-19, mostra a importância da utilização da tecnologia no dia a dia, pois ela auxilia a trabalhar, estudar, se comunicar com os demais e a fazer tarefa que presencialmente não seria possível, devido ao contexto pandêmico que se encontra. Isso faz com que seja perceptível, que o avanço da tecnologia foi de extrema importância para a evolução da humanidade. Segundo Simondon (1969) apud Kenski (1997), o homem utiliza recursos naturais, a sua disposição, provendo finalidades que Ihes permite melhorias no seu dia a dia e, por conseguinte a sua vida.

Todas essas questões não se diferem no contexto das aulas. A forma como elas estão sendo ministradas nesse período, em ensino remoto de emergência, revela que, a tecnologia sempre esteve favorecendo a educação. Segundo Hodges et al. (2020), o ensino remoto de emergência é uma mudança temporária de um modo de ensino alternativo devido a circunstancias de crise,já que assim que passar a pandemia, pretende-se voltar às aulas presenciais, pois, no presente momento, o uso de ferramentas tecnológicas está sendo indispensáveis para que possa ocorrer um ensino-aprendizagem mais coerente com o momento. Para isso, professores e alunos tem a disposição, ferramentas tecnológicas próprias ou adaptadas ao processo de ensino e desse modo, podem estudar. Além disso, pode-se perceber a importância de aplicativos usados nesse processo, pois, a forma como as aulas estão sendo ministradas hoje, requer o uso de aplicativos como: Google Meet, para poder ministrar aulas tanto ao vivo como gravações; o Google Classroom, no qual é feito salas de aulas onde o professor pode colocar atividades, textos, questionários, vídeos e; o Whatsapp, no qual o professor pode entrar em contato constantemente com seus alunos, através de grupos, favorecendo muito o processo do ensino.

Um grande problema que estudantes e professores têm na escola é a falta de laboratórios de ciência, fazendo com que, seja complicado ao professor mostrar na prática laboratorial o fenômeno físico apresentado na teoria. Segundo o INEP (2018), somente $44,1 \%$ das escolas brasileiras tem laboratório de ciências. 
Esse problema foi intensificado pela pandemia, pois mesmo as escolas que apresentam laboratório de ciência, não podem usá-lo, tornando mais complicado para o professor ensinar ciência, especificamente física, e ao aluno entender o fenômeno apresentado sem a possibilidade de percepção experimental. Por isso, é necessário um meio alternativo à falta de laboratório ou a falta de aulas práticas, seja resolvida. Nesse cenário é que se propõe a utilização de aplicativos com realidade virtual.

Esse trabalho tem como objetivo geral, fazer um levantamento bibliográfico de trabalhos relacionados à utilização da realidade virtual no ensino de física e de aplicativos de RV em lojas virtuais de smartphones e computadores, que poderão ser utilizados como um método alternativo de substituição de laboratório. Os objetivos específicos são mostrar que a (RV) pode ser usada como uma alternativa para a falta de laboratórios de ciência nas escolas; o aluno pode relacionar a teoria adquirida em aula com a prática dos fenômenos físicos; o ensino-aprendizagem dos alunos deve ser potencializado; estimular o interesse dos alunos, e; a utilização metodologias ativas pode fazer com que o aluno se torne agente principal do seu aprendizado.

Esse tema foi escolhido levando em consideração à falta de laboratórios nas escolas e a atual situação mundial, devido a Pandemia da Covid-19. Visto que, os alunos e professores têm à disposição recursos e ferramentas digitais gratuitas para usar como alternativa de ensino, fazendo com que, mesmo sem aulas presenciais e sem laboratório de ciências na escola, possam desenvolver um processo de ensino-aprendizagem mais eficaz e de qualidade. Lembrando que, a geração atual é uma geração "nativa digital" que tem facilidade de acesso e de manuseio das ferramentas tecnológicas.

\section{A TECNOLOGIA COMO FERRAMENTA EDUCACIONAL}

Segundo o Instituto Brasileiro de Geografia e Estatística (IBGE) (GLOBO, 2021), o Brasil atingiu em 2020, o total de 211,8 milhões de habitantes e, neste mesmo ano, cerca de 156,7 milhões são usuários de internet. Levando com consideração esses dados, pode-se ver que cerca de $73,9 \%$ da população brasileira 
usa e tem acesso a internet. Atualmente, celular não é apenas para classe média ou classe média alta, mas também para a população de níveis sociais mais baixos e também não se restringe apenas à zona urbana, sendo bastante utilizada pela população da zona rural.

A utilização da internet aumenta a cada dia mais, fazendo com que pessoas de todas as idades e classes tenham acesso a ela e que possam se comunicar a interagir através da mesma. A UNESCO (2014) afirma que:

"Ao contrário do que se pensa a aprendizagem móvel não aumenta o isolamento, mas sim oferecem às pessoas mais oportunidades de cultivar habilidades complexas exigidas para se trabalhar de forma mais produtiva com terceiros" (UNESCO, 2014, p.18)

A geração atual, por ser uma geração nativa digital, dentro do âmbito tecnológico, tem uma maior facilidade de se comunicar, de se expressar e de se conectar através da internet, mas sempre lembrando que infelizmente, a realidade ainda não é igual para todos. Segundo Jordão (2009):

"As tecnologias digitais são, sem dúvida, recursos muito próximo dos alunos, pois a rapidez de acesso às informações, a forma de acesso randômico, repleto de conexões, com incontáveis possibilidades de caminhos a se percorrer, como é o caso da internet, por exemplo, estão muito mais próximos de forma como o aluno pensa e aprende." (JORDÃO, 2009, p.10)

Pelo fato de ser uma geração muito conectada, o uso da internet como ferramenta educacional, se torna indispensável, levando em consideração a facilidade de acesso para a grande maioria das pessoas e de manuseamento de equipamentos tecnológicos.

Por conta da pandemia da Covid-19, o momento é histórico e propício para se fizer o uso de tecnologias educacionais e deixar de lado o ensino bancário, que segundo Paulo Freire (ECOA, 2020), o aluno era visto como um banco no qual o professor apenas depositava conhecimento e não um protagonista do seu próprio conhecimento. A tecnologia entra como ferramenta muito importante na organização e funcionamento de atividades que não podem ser realizada presencialmente, anterior ao contexto atual. 
As instituições de ensino vêm motivando cada vez mais estudantes a terem acesso à internet, como é o caso do Instituto Federal do Piauí - Campos Picos, que nos anos de 2020 e 2021 trouxe para a instituição recursos como notebooks, tablets, chips para smartphones e um auxílio mensal para ajuda de custo com gastos com meios de acesso a internet para os alunos carentes, fazendo com todos os alunos pudessem assistir e participar ativamente das aulas.

Hoje, existem muitos aplicativos, softwares e simuladores capazes de levar conhecimento ao estudante e possibilitá-lo a ser participativo na construção de sua identidade como estudante e pessoa. Com as ferramentas tecnológicas, os alunos passam a interagir mais, pois, cada um pode pegar seu celular e com a orientação do professor manusear uma simulação de um fenômeno físico e tirar suas próprias conclusões, correlacionando assim à teoria com a prática. Pois, se utilizado da maneira correta, a tecnologia favorece e muito o processo de ensino-aprendizagem dos estudantes, como é observado na fala de Vygotsky (1998):

"O momento de maior significado no curso do desenvolvimento intelectual, que dá origem às formas puramente humanas de inteligência prática e abstrata, acontece quando a fala e a atividade prática, então duas linhas completamente independentes de desenvolvimento, convergem." (VYGOTSKY, 1998, p. 27)

As tecnologias de informação e comunicação (TIC's) possibilitam aos estudantes vivenciarem processos criativos, fazendo uma relação entre vários recursos tecnológicos. Elas são uma série de recursos tecnológicos, que quando utilizados de maneira integrada, promovem melhorias múltiplas no processo de ensino aprendizagem. Segundo Lévy (1999), o mundo atual é de telecomunicações e de informática, levando a novas maneiras de pensar e de conviver, fazendo com que a interação entre homem e sociedade tenha a inserção de dispositivos de informática a todo tempo.

O uso da tecnologia no dia a dia cria uma necessidade de saber aplicar todo o potencial que ela tem em sala de aula no processo pedagógico e o processo de ensino aprendizagem, analisando as melhores maneiras de utilizar esse recurso no ensino (HAMZE, 2010). O (a) professor (a) deve saber analisar a melhor maneira de inserir as TIC's em sala de aula, possibilitando os alunos a fazerem um uso adequado e significativo. 


\section{A UTILIZAÇÃo dA REALIdAdE VIRTUAL (RV) NO PROCESSO DE CONSTRUÇÃO DO CONHECIMENTO}

A RV é um ambiente virtual onde as pessoas podem ser inseridas em um mundo virtual através de óculos, capacetes e outros anteparos, neles são encontrados efeitos visuais e sonoros, para que as pessoas tenham a sensação de estar dentro de um mundo virtual. Os primeiros usos do termo realidade virtual são datados por volta de 1938, pelo autor francês Antonin Artaud, no seu livro Le Théâtre et son double, sugerindo um teatro onde "a ilusão de personagens criava uma realidade virtual". Em 1970, Myron Krueger, um artista digital, desenvolvedor das primeiras instalações interativas usava o termo "realidade interativa" em seus estudos. Mas o termo realidade virtual (RV) que é utilizado hoje, veio através de Jaron Lanier, fundador do VPL Research Inc. no início dos anos 1980, ele o utilizou para diferenciar as simulações tradicionais realizadas por computadores de simulações envolvendo múltiplos usuários, em um ambiente compartilhado (tal como ocorrem em jogos que usam a realidade virtual).

O processo de construção do conhecimento ocorre através da interação de pessoa com pessoa e pessoa com ambiente. Da mesma maneira a realidade virtual é utilizada de modo que possa ocorrer essa interação de maneira mais direta e sucinta. Segundo Winn (1993), o processo psicológico que torna ativo a imersão da realidade virtual é muito semelhante ao modo com que as pessoas adquirem conhecimento, isto é, por meio da interação com objetos e o mundo real.

Nesse contexto, a realidade virtual vem como um meio em que professores e alunos podem usá-la para ser inserido em um ambiente virtual no qual quer ser estudado ou analisado mais detalhadamente e de maneira mais real, como ilustrado na figura 1 , onde a criança utiliza óculos de realidade virtual em sala de aula. As escolas podem e devem fazer a utilização de TIC's para maior aprendizado e aperfeiçoamento de seus alunos, elevando-os a um patamar mais alto de conhecimento e as formas que esses conhecimentos são transmitidos. Segundo Bezerra (2018): 
"As tecnologias contemporâneas e todo seu universo (dispositivos móveis, aplicativos, entre outros) que continuam a se expandir, estão inseridos na sociedade e fazem parte do cotidiano de grande parte da população, por isso, deve-se analisar como inserir essas ferramentas no processo de ensino-aprendizagem" (BEZERRA, 2018, p.19).

A realidade virtual pode levar os indivíduos a ter uma relação intrapessoal num ambiente virtual onde ele é capaz de aprender com referencia a objetos da realidade e menos conceitos abstratos, vários fenômenos e logo após, transmitir esse conhecimento aos demais, em uma relação interpessoal.

Figura 1 - Realidade Virtual na escola

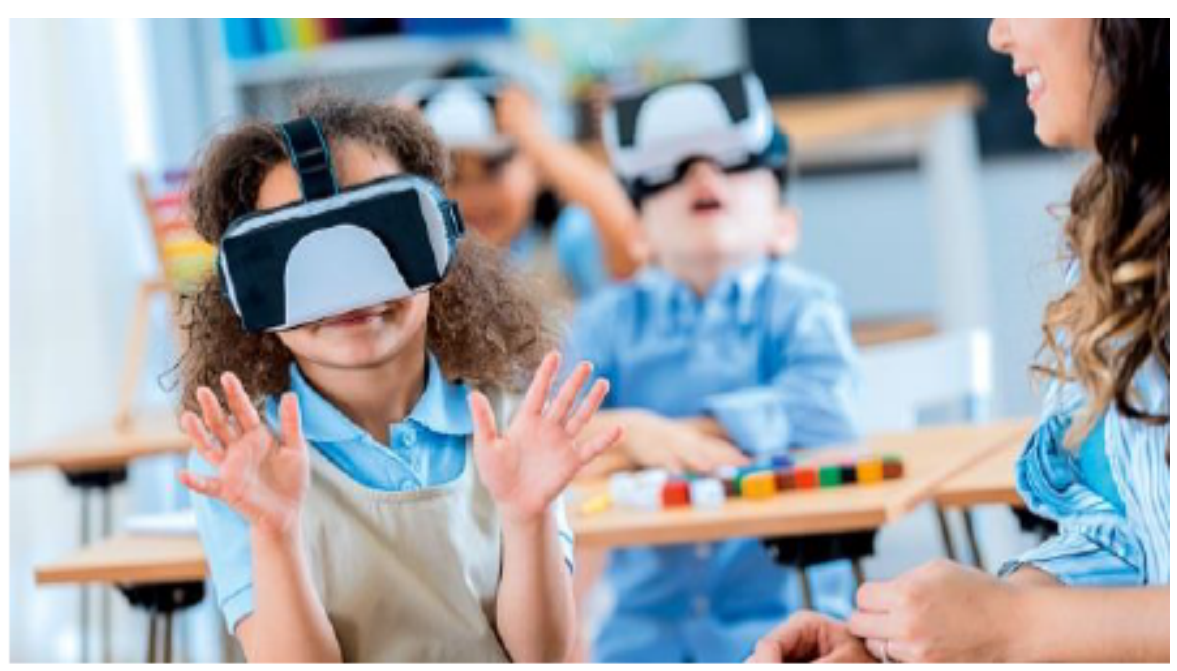

Fonte: istoe.com.br. Acesso em: 19 jun. 2021

Com base em Tori (2010), a realidade virtual é uma ferramenta de grande valia para a educação, proporcionando benefícios aos alunos e aos professores, pois de forma viável e de fácil acesso, ela pode ser usada. Aplicativos de realidade virtual estão presentes de forma gratuita em lojas de aplicativos de celulares e computadores, onde ainda, pode ser usada como meio imersivo e não-imersivo, sendo o primeiro com o uso de óculos ou capacetes e o segundo sem uso necessário de óculos ou capacete específico, tornando possível com que aqueles alunos que não tenham condições financeiras de comprá-los, não precisem gastar dinheiro. Mas usando meio imersivo ou não, ela proporciona uma experiência incrível para seu utilizador, podendo ver de maneira realista os fenômenos, mesmo que sendo por um meio virtual. 
Levando em consideração o contexto atual em que o mundo vem vivendo, pode-se perceber que, a realidade virtual é uma alternativa para substituição de laboratório de ciências, já que não é possível, em muitas escolas, ter contato com os alunos. A RV pode ser usada como ferramenta educacional para ajudar e contribuir com o processo de construção do conhecimento.

Segundo o Sistema Educacional Brasileiro - SEB (2021) destaca alguns motivos pelos quais a realidade virtual deve ser usada na educação:

- Dá acesso remoto, permitindo os estudantes se conectarem com outros estudantes de qualquer lugar do mundo;

- Propicia habilidades importantes, como disciplina, autonomia e empatia;

- Aumenta a motivação e o foco, fazendo com o os estudantes tenham mais vontade e interesse para estudar determinado conteúdo.

\section{METODOLOGIAS ATIVAS NO ENSINO}

Infelizmente, ainda é muito comum ver escolas usando a famosa educação tradicional, onde o professor é o detentor do conhecimento e os alunos são apenas receptores, que decoram e memorizam sem ao menos entender o que de fato é o conceito que ele aprendeu. Um dos meios utilizados para contrapor essa educação tradicional são as metodologias ativas. Segundo Tavares (2019), essas metodologias são práticas inovadoras capazes de fazer o aluno se tornar protagonista e ativo do seu processo de ensino e o professor um facilitador desse processo de aprendizagem.

Segundo Fernandes (2011), o pesquisador norte-americano David Ausubel, fundador da teoria da aprendizagem significativa afirma que a aprendizagem tradicional e a aprendizagem significativa são antagônicas, pois enquanto a tradicional concentra seu foco no professor, a significativa concentra seu foco no aluno e no seu potencial. Na aprendizagem significativa, o aluno ele já vem pra escola com conhecimentos prévios adquiridos através de interações com pessoas e com o ambiente e, que o professor, deve fazer uso desse conhecimento prévio dos alunos explorando-os, analisando-os, contextualizando-os e levando 
o aluno a aprender de maneira mais significativa e com um real sentido os para sua vida.

Quando o professor faz um bom planejamento e consegue inserir o aluno de modo que ele seja o protagonista no seu processo de aprendizagem, o ensino se torna mais efetivo. Com o uso de metodologias ativas, o professor consegue fazer com que o aluno possa participar mais ativamente, fazendo assim, com que o mesmo possa desenvolver várias habilidades e um criticidade de pesquisa. Esse é o intuito em usar a realidade virtual como uma alternativa de ensino, pois, o objetivo é levar o aluno a procurar entender como ocorre os fenômenos vendo-os através de um mundo virtual.

Como mostrado na figura 2, às metodologias ativas tem um papel importante de dar autonomia ao aluno, para que ele seja o centro do processo de construção do ensino. O professor por sua vez, tem seu papel fundamental como facilitar e mediar desse conhecimento que será repassado para o aluno, sempre integrando o conhecimento formal com as informações prévias que o aluno já tem.

Figura 2 - Metodologias Ativas no ensino

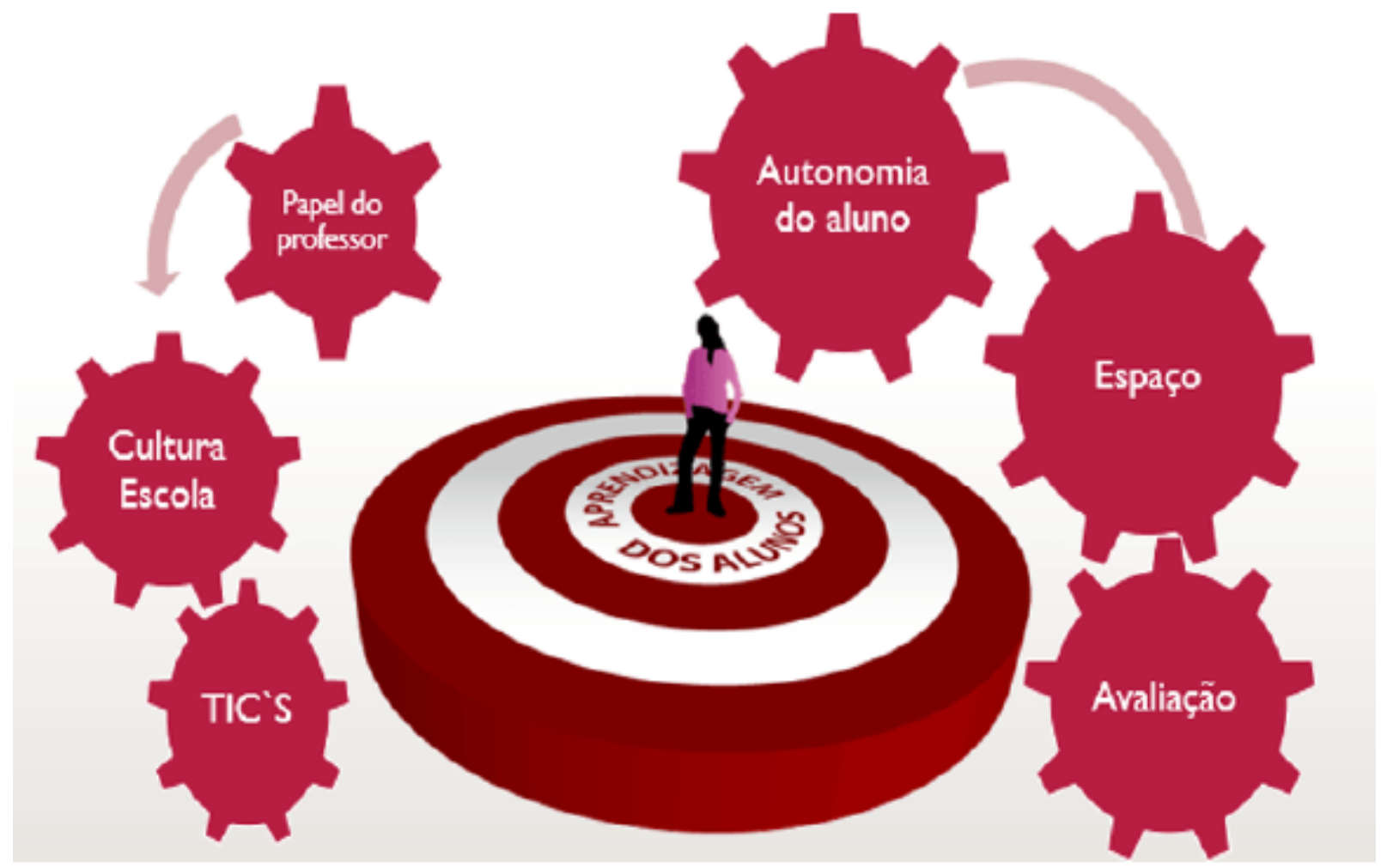

Fonte: novaescola.org.br; Acesso em: 19 jun. 2021 


\section{LEVANTAMENTO DE APLICATIVOS DE RV NO ENSINO DE FíSICA}

Foi feito um levantamento de artigos sobre realidade virtual no ensino de física em sites científicos como Google Acadêmico, o portal de Periódicos da Capes, na Revista Brasileira de Ensino de Física e em sites de educação. As buscas foram feitas por artigos e trabalhos que envolviam o uso da RV como ferramenta de ensino e suas aplicações em sala de aula, sendo selecionados cerca de oito trabalhos que mais se encaixavam com o tema proposto, usando alguns critérios, como datam de publicação, escrito em língua portuguesa e que apresentassem características claras sobre a RV.

Para a escolha dos aplicativos, foi utilizado o Google e a loja Play Store, buscando por aplicativos de RV que pudessem ser utilizados para o ensino de física. Nessa busca por aplicativos, houve certa dificuldade, pois, quando é pesquisado sobre aplicativos para o ensino de física, são encontrados mais aplicativos cuja finalidade é resolver questões com fórmulas matemáticas para o ENEM e provas tradicionais. Existem poucos aplicativos de ensino de física utilizando a RV. Os critérios utilizados para a escolha dos aplicativos foram por aqueles que fossem bem ilustrativos e que se enquadrassem no âmbito educacional, podendo ser jogos ou não, de fácil manuseio e que não tivessem equações matemáticas, pois o proposito não era resolver questões. O período de busca e análise desses trabalhos acadêmicos e de aplicativos de RV foi de Março de 2021 até Junho de 2021.

Abaixo, são apresentados alguns aplicativos com suas respectivas características, que fazem o uso da realidade virtual para o ensino de física de forma dinâmica, divertida e criativa, levando os alunos a uma experiência incrível e construtiva sobre alguns fenômenos físicos.

\section{APLICATIVO DE REALIDADE VIRTUAL PARA O ESTUdO DA CINEMÁTICA:}

Com esse aplicativo de realidade virtual chamado de Aplicativo VR Thrills: Roller Coastrer 360 pode-se ensinar para o aluno alguns conceitos básicos de cinemática física através do movimento de uma montanha russa, conforme 
apresentado na figura 3, onde é mostrado o print de um momento do aplicativo, com: 1) movimento e repouso, no qual, o professor pode adotar um referencial juntamente com os alunos e analisar como são esses conceitos; 2) trajetória, o professor pode mostrar a seus alunos a trajetória percorrida pelo carrinho na montanha russa que é o caminho percorrido durante certo intervalo de tempo; 3 ) velocidade, onde através da variação do espaço e tempo, o aluno pode aprender o conceito de velocidade e o professor pode até adotar medidas para que sejam calculadas matematicamente e; 4) aceleração, na qual o professor pode mostrar a seus alunos que através da variação da velocidade do carrinho da montanha russa pode-se calcular e entender o conceito de aceleração. Onde velocidade e aceleração são dadas pelas equações (1) e (2):

$$
\begin{aligned}
& \text { Eq. } 1 \\
& \qquad V_{m}=\frac{\Delta S}{\Delta t}
\end{aligned}
$$

Onde:

- Vm é a velocidade média

- $\Delta S$ é o deslocamento

- $\Delta$ t é o intervalo de tempo

$$
\text { Eq. } 2 \quad a_{m}=\frac{\Delta V}{\Delta t}
$$

Onde:

- $a_{m}$ é a aceleração média

- $\Delta \mathrm{V}$ é a variação da velocidade

- $\Delta$ t é a variação do tempo 
Figura 3 - Aplicativo VR Thrills: Roller Coastrer 360

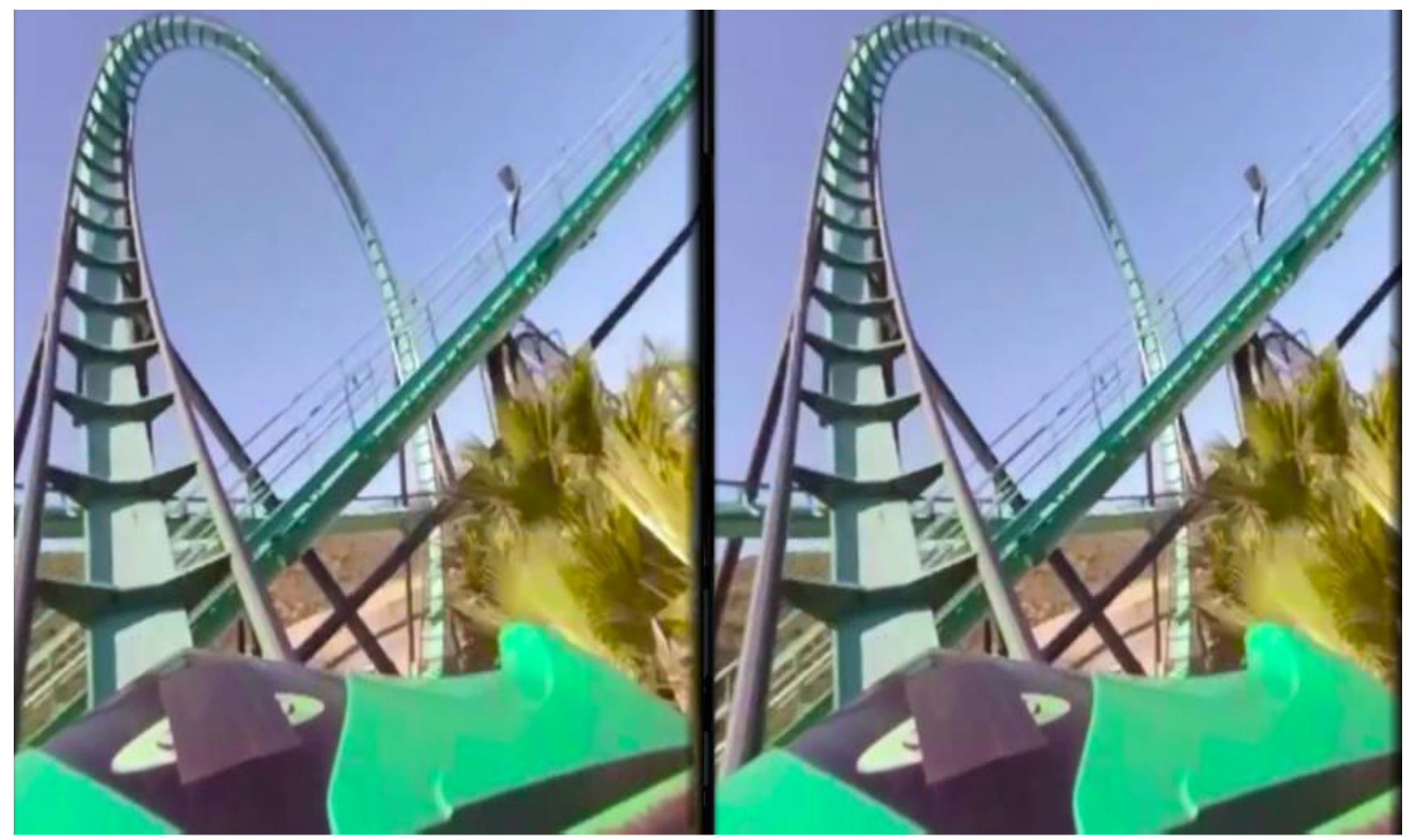

Fonte: apk.support; Acesso em: 21 jun. 2021

\section{APLICATIVO DE REALIDADE VIRTUAL PARA O ESTUdO DA ASTRONOMIA}

O aplicativo de realidade virtual Solar System Scope conforme mostrado na figura 4, é um excelente aplicativo que pode ser usado tanto em forma de realidade virtual como de forma mecânica com a mão. Ele mostra o funcionamento do sistema solar, como os planetas, estrelas e satélites estão distribuídos no espaço, mostra também quais os elementos químicos de que os planetas são feitos, suas dimensões, suas massas, mostra sua história de como e quando foram descobertos. Um excelente aplicativo para se trabalhar virtualmente como os alunos o conteúdo de astronomia. Esse aplicativo ocupa pouca memória do celular, é de fácil manuseio principalmente para essa geração nativa digital e é um aplicativo que desperta interesse nos alunos, pois, eles passam a aprender de maneira mais eficiente. 
Figura 4: aplicativo Solar System Scope

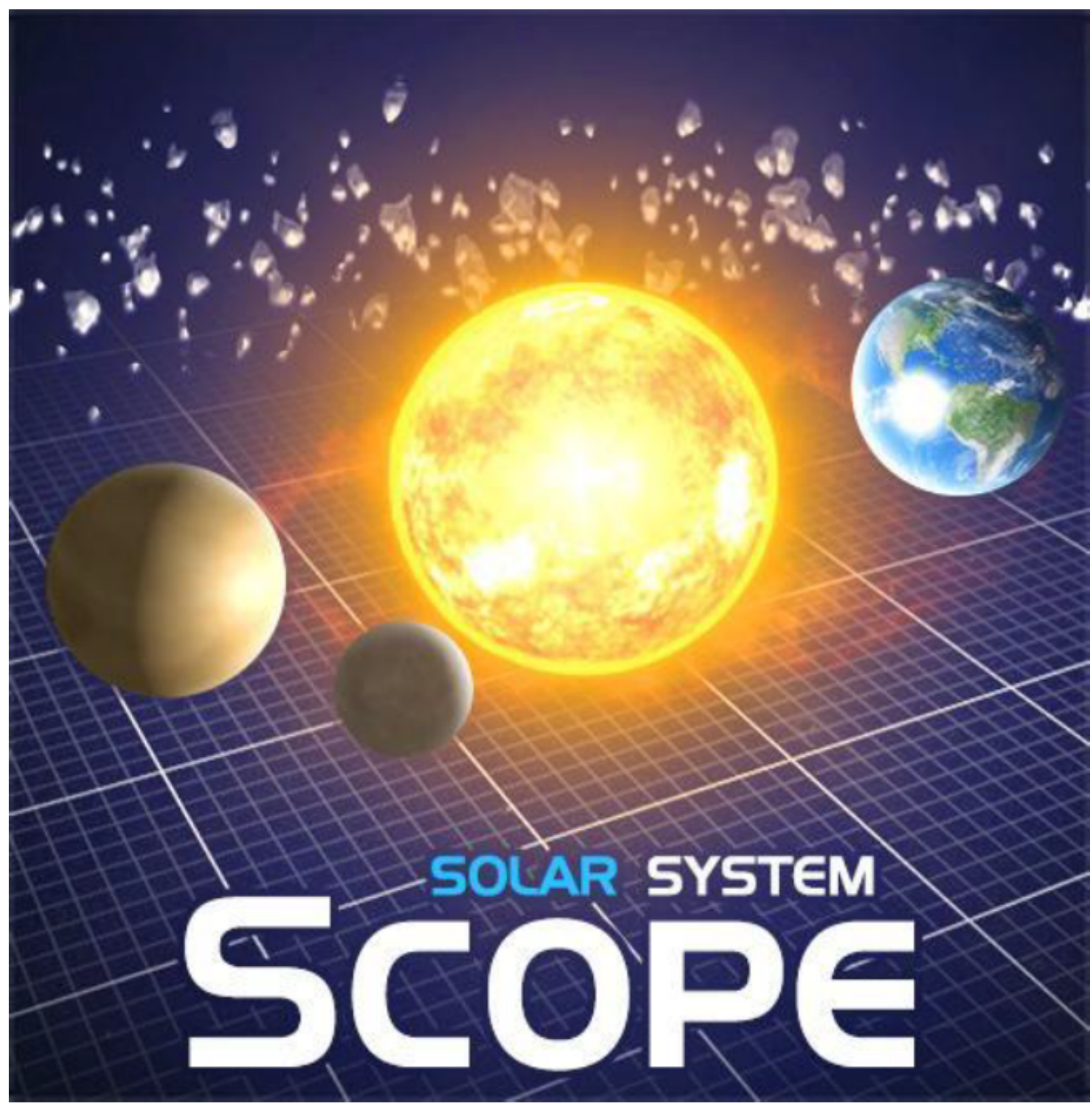

Fonte: play.google.br; Acesso em: 21 jun. 2021

A partir desse aplicativo, o professor poderá trabalhar com seus alunos os seguintes conteúdos: composição do sistema solar, estrelas, planetas, satélites naturais, gravidade, elementos químicos que compões o sistema solar e o heliocentrismo. Na figura 7 mostra um pouco como o Sistema Solar está representado no aplicativo, levando seus usuários a ter uma sensação bem dinâmica e interativa de como é o Sistema Solar. 
Figura 7: print do funcionamento do aplicativo Solar System Scope

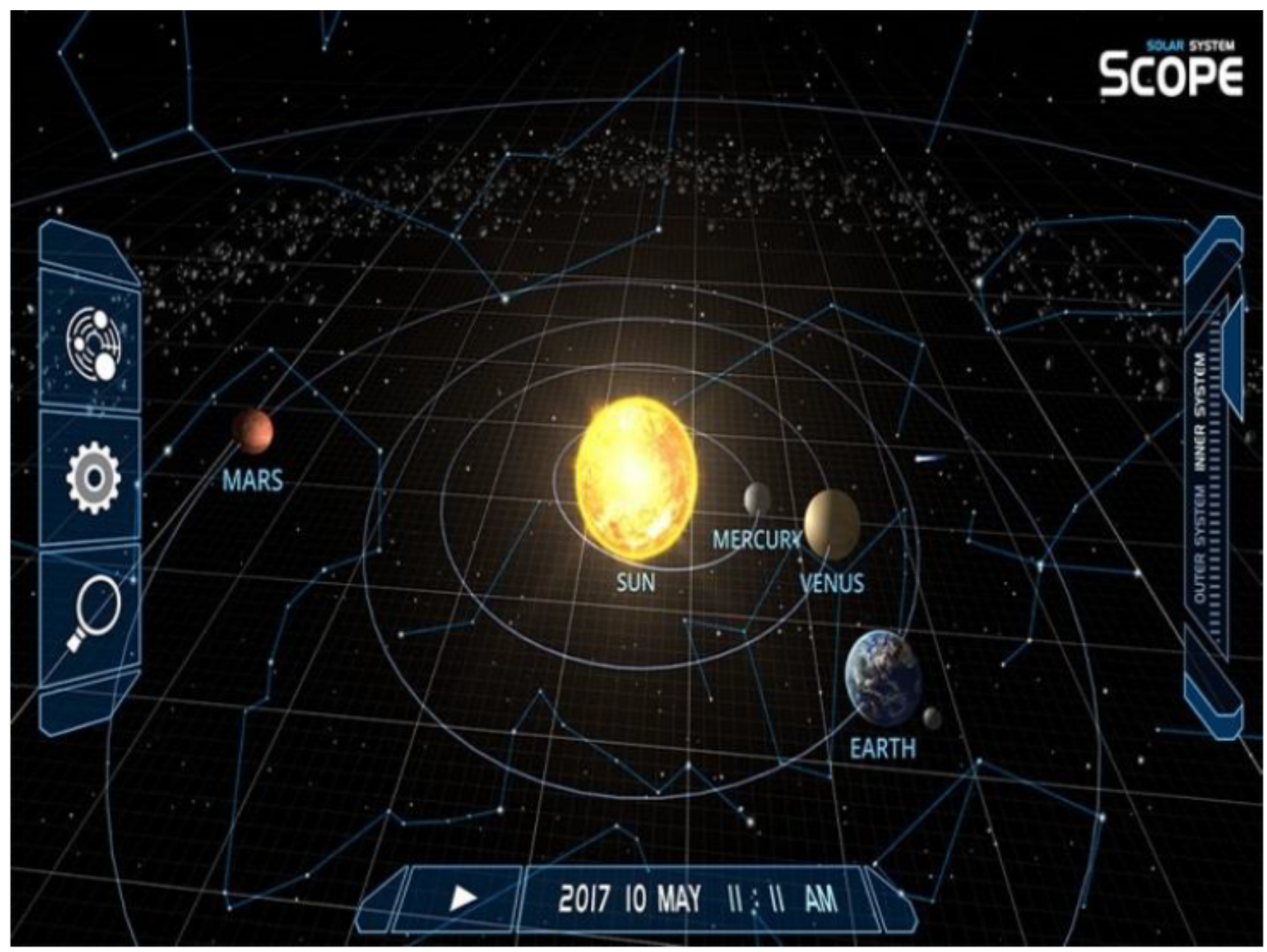

Fonte: pcguia.pt;Acesso em: 21 jun. 2021

Através desse aplicativo de realidade virtual, o (a) professor (a) pode ensinar e mostrar a seus alunos o conceito e aplicação da força gravitacional e diferenciar com a força gravitacional da Terra, ensinando-lhes que a gravitação é o estudo das forças de atração entre massas (forças de campo gravitacional) e dos movimentos de corpos submetidos a essas forças, calculada através da Lei de Newton sobre a atração das massas, dada pela equação (4):

$$
\text { Eq. } 4 \quad F=G \frac{M a M b}{d^{2}}
$$

Onde:

- F é a força de atração entre as massas

- $G$ é a constante gravitacional

- $M_{a}$ é a massa do corpo a

- $d$ é a distância dos corpos ao quadrado

- $M_{b}$ é a massa do corpo b 


\section{DISCUSSÃO}

Na busca por trabalhos acadêmicos desse tema, pode-se perceber que ainda é muito difícil encontrar trabalhos relacionando ensino de física e realidade virtual. Quando se busca em fontes de pesquisa o termo "realidade virtual no ensino" vai muito para a área da saúde, da engenharia e da informática, mas pouco se encontra sobre o ensino de física. Mas, mesmo não sendo encontrados muitos trabalhos sobre realidade virtual no ensino de física, os que têm, já servem como um auxílio, um embasamento sólido para começar a estudar sobre o assunto e, através desses trabalhos, é possível sim associar o ensino de física com a realidade virtual.

Nos artigos que dão base a esse trabalho ${ }^{1}$, pode-se analisar que existem algumas dificuldades para a implementação da realidade virtual nas aulas, pois existe uma série de fatores como falta de internet, falta de smartphones ou computadores (ARRUDA; SILVA; BEZERRA, 2020) e até mesmo falta de preparo e embasamento para o professor (RESENDE, 2019), mas, em contra partida, são inúmeros os benefícios e qualidade de ensino que a RV pode trazer para o ensino de física, como foi destacado no decorrer do texto. Então, mesmo com algumas dificuldades, é visto que a RV vem para somar e é uma alternativa para trazer mudanças necessárias para o âmbito educacional.

A mesma dificuldade é percebida em relação aos aplicativos de realidade virtual. Existem muitos aplicativos de realidade virtual na loja de aplicativos de smartphone, a Play Store, mas são pouquíssimos em relação ao ensino de física. Infelizmente, essa realidade não colabora muito com a necessidade cada vez maior de ferramentas capazes de auxiliar professores e alunos no desenvolvimento do processo de ensino aprendizagem.

Grande parte dos alunos de física acham a matéria muito complicada, sem aplicação e até mesmo matemática pura, e não conseguem entender de fato o conceito dos fenômenos físicos. Sabe-se que a matemática é de suma importância, pois é através dela que consegue se provar um fenômeno, mas deve-se

1 A partir desse levantamento, tivemos os seguintes trabalhos: ARRUDA; SILVA; BEZERRA (2020); BEZERRA (2018); BRAGA (2001); JORDÃO (2009); RESENDE (2019); SILVA; FERREIRA; VIEIRA (2017); SILVA; ZORZAL; OLIVEIRA (2008); TORI (2010). 
destacar também que é importante que o aluno consiga associar essa matemática com o fenômeno estudado, para que assim, ele possa aprender o verdadeiro significado físico.

A falta de laboratório de ciência, a falta de dispositivos tecnológicos que possam ser uma alternativa pra esse problema, a falta de recursos por parte da escola ou do professor para levar para a turma experimentos de baixo custo, mostram um ensino defasado, desajustado e mecânico. Com isso, a realidade virtual vem como alternativa viável de substituição de laboratório para o ensino de física, levando o aluno a ter uma compreensão mais ampla sobre os fenômenos físicos estudados. Quando o professor faz uma ligação do que foi estudado na teoria com a realidade mostrada no aplicativo através da RV, o aluno consegue ter uma visão mais ampla e eficiente sobre o que ele está estudando e de fato, esse aluno começa a ter mais vontade de estudar e aprender física, pois ele passa a entender onde e como a física que ele estuda está sendo aplicada no seu dia a dia.

Os aplicativos citados no desenvolvimento englobam algumas áreas da física, como cinemática, gravidade e astronomia (pois só foi possível encontrar aplicativos de realidade virtual para essas áreas), onde é possível aprender a física de forma interessante e realista. O professor pode ensinar vários conceitos físicos a seus alunos como: movimento e repouso, trajetória, intervalo de tempo, velocidade, aceleração, gravitação, Lei da atração de massas, sistema solar, planetas, estrelas, satélites, heliocentrismo e os elementos químicos existentes no espaço.

\section{CONSIDERAÇÕES FINAIS}

Esse trabalho teve o intuito de gerar uma reflexão crítica em relação a materiais didáticos para o ensino de física nas escolas, caracterizado pelo cenário de aulas remotas e sinalizando para o desenvolvimento de mais aplicativos, dispositivos e materiais didáticos capazes de suprir a necessidade da falta de material desse cunho para o ensino de física. Uma boa didática na maneira de ensinar física, utilizando os recursos disponíveis, pode fazer com que o aluno tenha mais 
segurança da sua aprendizagem, nesse sentido, a RV entra como um recurso válido e alternativo para um ensino eficiente.

Apesar dos trabalhos apontados no levantamento bibliográfico apontarem para um cenário ainda em desenvolvimento e precário em alguns aspectos, observou-se potencialidades no que diz respeito á utilização da tecnologia de Realidade Virtual no âmbito educacional, pois, ela pode ser usada como ferramenta didática de ensino, possibilita uma construção de processos criativos e ilustrativos, traz uma visualização mais realista de fenômenos físicos, tem a capacidade de aumentar a motivação e o foco dos estudantes e torna o aluno protagonista de autor do seu processo de construção do seu conhecimento.

\section{REFERÊNCIAS}

ARRUDA, G. Q.; SILVA, J. S. R.; BEZERRA, M. A. D. O uso de tecnologias e suas dificuldades enfrentadas por educadores e educandos em meio a pandemia. Conedu - VII Congresso Nacional de Educação. Maceió - AL, 2020.

BEZERRA, J. C. A realidade virtual como ferramenta didática para o ensino de Astronomia e Cosmologia na educação básica. (Dissertação de Mestrado em Ensino de Física) - UEPB. Campina Grande - PB, 2018.

BRAGA, M. Realidade Virtual e Educação. Revista de Biologia e Ciências da Terra, v. 1, n. 1; Minas Gerais, 2001.

ECOA, M. C. O que são a educação bancária e libertadora formuladas por Paulo Freire? 2020. Disponível em: https://www.uol.com.br/ecoa/ultimas-noticias/2020/12/01/o-que-sao-a-educacao-bancaria-e-a-libertadora-formuladas-por-p-freire.htm Acesso em 15 de mai. de 2021.

FERNANDES, E. David Ausubel e a aprendizagem significativa. 2011. Disponível em: https://novaescola.org.br/conteudo/262/david-ausubel-e-a-aprendizagem-significativa Acesso em 31 de mai. de 2021.

GLOBO. Brasil atinge 211,8 milhões de habitantes no ano de 2020, diz IBGE. G1 Economia. 27 de Ago. 2020. Disponível em: https://g1.globo.com/economia/noticia/2020/08/27/brasil-atinge-2117-milhoes-de-habitantes-diz-ibge.ghtml Acesso em 31 de mai. de 2021 
HAMZE, A. A linguagem Audiovisual e a Educação. 2010. Disponível em: https:// educador.brasilescola.uol.com.br/gestao-educacional/linguagem.htm. Acesso em 15 de mai. de 2021.

HODGES, C.; TRUST, T.; MOORE, S.; LOCKEE, B.; Diferença entre o aprendizado online e o ensino remoto de emergência. EDUCAUSE Review. Traduzido por Danilo Aguiar, Dr. Américo N. Amorim e Dra. Lídia Cerqueira. EUA, 2020.

INEP. DADOS DO CENSO ESCOLAR - Noventa e cinco por cento das escolas de ensino médio têm acesso à internet, mas apenas $44 \%$ têm laboratório de ciências. Disponível em :http://portal.inep.gov.br/artigo/-/asset_publisher/ B4AQV9zFY7Bv/content/dados-do-censo-escolar-noventa-e-cinco-por-cento-das-escolas-de-ensino-medio-tem-acesso-a-internet-mas-apenas-44 -tem-laboratorio-de-ciencias/21206. Acesso em 10 de mai. de 2021.

JORDÃO, A. T. Formação de educadores: A formação do professor para a educação em um mundo digital. In. BRASIL. Secretária de Educação á Distância. TV Brasil. Boletim Salto para o futuro: Tecnologias digitais na educação. Brasília, DF: MEC/SEED, 2009.

KENSKI, V. M. Novas Tecnologias. O redimensionamento do espaço e do tempo e os impactos no trabalho docente. XX Reunião Anual da ANPEd, Caxambu - MG, 1997.

LÉVY, P.; Cibercultura. Ed. 34. São Paulo, 1999.

RESENDE, B.; SANTOS, M. G. Virtualização e Educação: desafios além da realidade. In: Seminário Internacional de Educação, Tecnologia e Sociedade: Ensino Híbrido - FACCAT. Rio Grande do Sul, 2019.

SEB. Realidade virtual é aplicada com sucesso na educação. Catraca Livre, 2021. Disponível em: https://catracalivre.com.br/educacao/realidade-virtual-e-aplicada-com-sucesso-na-educacao/ . Acesso em 20 de mai. de 2021.

SILVA, A. F.; FERREIRA, J.H.; VIEIRA, C. A. O ENSINO DE CIÊNCIAS NO ENSINO FUNDAMENTAL E MÉDIO: reflexões e perspectivas sobre a educação transformadora. Revista Exitus, v. 7, n. 2; Minas Gerais, 2017. 
SILVA, L. F.; ZORZAL, E. R.; OLIVEIRA, M. R. F.; CARDOSO, A.; JUNIOR, E. A. L.; MENDES, E. B.; TAKAHASHI, E. K.; MARTINS, S. Realidade Virtual e Ferramentas Cognitivas Usadas como Auxílio para o Ensino de Física. CNPQ, v. 6, n. 1; Rio Grande do Sul, 2008.

TAVARES, P. A. Metodologias ativas: o papel do professor como facilitador do aprendizado dos alunos. Disponível em: https://novaescola.org.br/conteudo/15340/metodologias-ativas-o-papel-do-professor-como-facilitador-do-aprendizado-dos-alunos . Acesso em 21 de mai. de 2021.

TORI, R. Educação Sem Distâncias: As tecnologias Interativas na Redução de Distâncias em Ensino e Aprendizagem. Ed. SENAC São Paulo. São Paulo, 2010.

UNESCO. Diretrizes de Políticas da UNESCO para a aprendizagem móvel. Paris. UNESCO Publications. ISBN: 978-85-7652-190-7. Traduzido pela UNESCO Brasil, 2014.

VIGOTSKY, L. S. A formação social da mente. Livraria Martins Fontes, EDITORA Ltda. São Paulo, 1998.

WINN, W. Uma base conceitual para aplicações educacionais de realidade virtual. Laboratório de Tecnologia de Interface Humana William Winn. Centro de Tecnologia de Washington. Washington, 1993. 


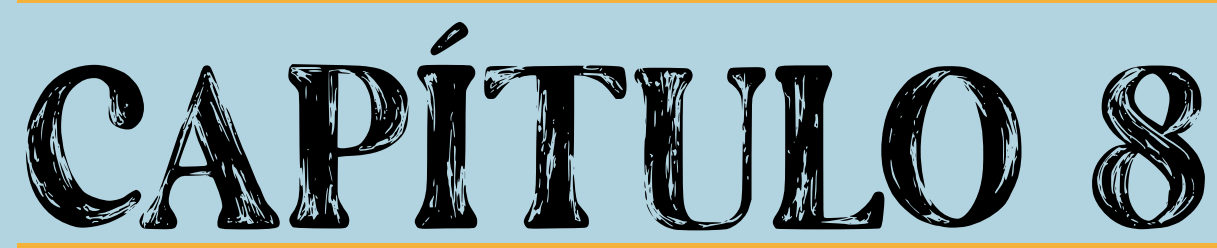

\section{ATIVIDADES REMOTAS NA DISCIPLINA DE CIÊNCIAS E AS POSSIBILIDADES PARA UM PERÍODO PÓS-PANDEMIA}

Thomáz da Silva Guerreiro Botelho Maria Inês de Affonseca Jardim Amanda de Mattos Pereira Mano 


\section{INTRODUÇÃO}

Se a escola fosse um aplicativo de celular diríamos que obrigatoriamente teve que passar por atualizações em seu formato durante a pandemia da COVID-19. Além disso, seus usuários tiveram que aceitar os novos termos e condições para o seu uso, inclusive as novas políticas. Nesse processo, todos os seus usuários tiveram que lidar com novas ferramentas (upgrades) para que o processo de ensino-aprendizagem fosse mantido. Considerando estas novas implicações para o ensino, a própria Organização das Nações Unidas para a Educação, a Ciência e a Cultura (UNESCO) emitiu recomendações para esse período, incluindo como prioridades para as instituições de educação a análise das melhores ferramentas a serem utilizadas, programas de inclusão digital, proteção de dados, relevância para questões psicossociais, elaboração de cronogramas para tratar de estratégias educacionais, formações continuadas para professores e diferentes abordagens para avaliação de alunos (UNESCO, 2020).

Nesse momento de transições, que implicam a educação e sociedade em geral, surgem questionamentos acerca das posturas de professores e de alunos na disciplina de Ciências, área que envolve certos níveis de abstração, complexidade de conceitos e linguagens pouco comuns (WHITE, 1994). A respostas para essas indagações não são tão simples, isto é, não se trata de somente transpor o presencial para o remoto, mas de estruturar estratégias positivas para professores de Ciências na educação básica para um uso combinado de Tecnologias Educacionais nas suas as aulas também em um período póspandêmico. Posto isto, reflexões realizadas nessas circunstâncias permitem repensar sobre metodologias ativas, em especial o ensino híbrido, apresentados como promotoras de um ensino mais centrado no aluno, considerando seu tempo e autonomia (BACICH et al., 2015; BACICH; MORAN, 2018).

O uso de ferramentas síncronas e assíncronas abriram espaço para debates em relação a adoção de práticas inovadoras, representadas por programas que contemplam a sala de aula e o ensino online. Nesse novo universo, a vida escolar do estudante tende a ser mais acompanhada do que regida por simples aulas, suas aptidões individuais são mais requeridas (DEMO, 2007) e as metodologias 
ativas lhe permitem assumir esse papel mais reflexivo e questionador (MORÁN, 2015). No ensino híbrido, os alunos podem exercitar esses princípios através de estratégias que incluem atividades mistas de tutoria individual e em pequenos grupos, optando por roteiros para o seu aprendizado com o uso do ensino online (HORN; STAKER, 2015).

Exercitar essas discussões não quer dizer que haverá manuais que exercem controle de como as atividades deverão ser realizadas, nem mesmo que superaremos subitamente os desafios do ensino de ciências. Porém, não tirarão o crédito de que os conhecimentos produzidos no período contribuem com o presente cenário e as diferentes demandas trazidas por professores de Ciências podem contribuir com suas práticas (BORBA et al., 2020). Simultaneamente, as avaliações obtidas com o desempenho dos alunos terão o papel similar aos comentários obtidos por avaliações em aplicativos de celular, por exemplo, que muitas vezes fornecem informações preciosas para o engajamento de seus usuários (DI SORBO et al., 2016)

Ao considerar as premissas apontadas, este estudo avaliou o desempenho e a conduta dos alunos, no período de pandemia, na realização de atividades remotas, por meio das relações entre o número de atividades realizadas, médias obtidas e procura dos alunos para sua conclusão, bem como verificou-se os meios de comunicação mais utilizados para realização das atividades propostas. A partir disto discutem-se caminhos e novas possibilidades para a organização do trabalho pedagógico na disciplina de ciências.

\section{DESENVOLVIMENTO}

Para realização deste estudo foram avaliadas as ações de alunos do sexto ao nono ano no que se diz respeito à realização das atividades da disciplina de Ciências, contemplando todas as aulas remotas do ano de 2020 em uma escola pública do Estado de Mato Grosso do Sul. A realização do estudo compreendeu o período de 23/03 a 21/12, no qual a Secretaria de Estado de Educação (SED-MS) suspendeu as aulas presenciais em todas as escolas da Rede Estadual de Educação. Durante os bimestres do período correspondente, 
os alunos puderam optar por entregar as atividades por preenchimento de Formulários Google (GOOGLE') disponibilizados em links na plataforma Google classroom (GOOGLE²), grupos de WhatsApp, blog da Escola ou optar pelas atividades impressas disponíveis na secretaria da escola e, assim, enviar fotos das respostas pelos grupos WhatsApp ou entregá-las em datas específicas para evitar aglomerações.

Para todas as atividades foram gravadas videoaulas, contendo slides e animações elaborados pelo professor de Ciências para serem disponibilizadas no canal da escola no Youtube. Foram enviados resumos das aulas em estudo dirigido impresso e PDF das aulas, que foram compartilhados nos grupos de WhatsApp, Google classroom (GOOGLE²) e blog da escola. Os alunos ainda tinham a opção de serem atendidos em plantões presenciais semanais caso não conseguissem acessar esses materiais ou não compreendessem a sua execução, sempre respeitando as normas de biossegurança e horários de escala entre professores. Juntamente com as atividades foram disponibilizados guias para o acesso às plataformas, tutoriais em vídeo explicando como deveria ser realizado o acesso ao blog da escola e Google classroom (GOOGLE²).

As atividades (online e/ou impressas) foram contabilizadas em uma matriz binária de dados, considerando 1 para a sua entrega e 0 para os alunos que não fizeram. Também foram plotadas em gráficos de desempenho das turmas as médias bimestrais obtidas nas atividades remotas. Os dois valores foram cruzados em um histograma no software Microsoft Excel $2016 \AA$ a fim de comparar as notas obtidas com a entrega das atividades remotas. Essa última análise foi realizada com o objetivo de identificar o sucesso na execução das atividades, uma vez que existe a possibilidade dos alunos terem entregado atividades sem concluir todas questões propostas. Também foram consideradas nessa avaliação as opções de buscas ativas, nome dado as estratégias objetivadas em conferir se o estudante estava em dia com as atividades, alertando sobre os prazos de fechamentos de notas e possibilidades de recuperação das mesmas. 


\section{RESULTADOS E DISCUSSÃO}

O acesso aos materiais disponibilizados foi realizado com maior frequência no WhatsApp, plataforma de maior familiaridade por parte dos alunos das turmas investigadas e professor de Ciências. As funcionalidades desse aplicativo puderam e podem auxiliar cada vez mais os alunos nas atividades remotas, permitindo uma rápida troca de informação entre o professor e os alunos por meio da criação de grupos de sala, onde é possível enviar imagens, vídeos e áudios para esclarecimento de dúvidas (SANTOS et al., 2016). Esta ferramenta também se destaca por sua simplicidade técnica e aproximação de relações com o professor no que se diz respeito a vantagens educacionais; no campo instrucional permite o aprendizado por intermédio de uma variedade de materiais e com possibilidade de correção imediata (BOUHNIK; DESHEN, 2014).

Os alunos também relataram ter mais facilidade em resolver as atividades quando assistiam as videoaulas, tanto que houveram áudios de alunos no grupo dizendo aos demais colegas que os aconselhavam realizar a atividade lado a lado com os vídeos do professor de Ciências. Essa importância dada aos conteúdos audiovisuais voltados as disciplinas de Ciências da natureza já têm sido discutidas amplamente, condição reconhecida pelo aumento de buscas e materiais audiovisuais da área no Youtube (REZENDE FILHO et al., 2011), materiais que permitem traçar ações com vistas a propostas de metodologias ativas em momentos pós-pandemia, iniciando as aulas com debates sobre vídeos assistidos pelos alunos, perguntas elaboradas em casa e um melhor aproveitamento do assunto a ser trabalhado presencialmente na escola (BERGMANN; SAMS, 2012)

O acesso assíduo ao WhatsApp e Youtube acabou inutilizando o blog da escola, sendo este dispensado pelos alunos. Dentre os motivos apresentados foram as dificuldades de acesso através de links por parte dos alunos e alguns professores tendo dificuldades em fazer uploads de materiais devido aos aspectos funcionais do blog, isso fazia com que muitas atividades a serem postadas demorassem para ficar disponíveis para os alunos. Portanto, produzir conteúdo para o blog e mantê-lo atualizado fez com que a instantaneidade das outras ferramentas ganhasse preferência, motivo pelo qual toda equipe pedagógica optasse em desabilitar o acesso ao mesmo. 
Além do blog da escola, a plataforma do Google classroom (GOOGLE²) também for pouco utilizada quando os links de formulários foram disponibilizados diretamente nos grupos de WhatsApp das turmas; Da mesma maneira, os plantões presenciais escalonados também foram dispensados a partir do momento que as dúvidas puderam ser sanadas por WhatsApp. Todavia, ainda que não presenciais, em muitos momentos foram precisos atendimentos diferenciados para certos alunos, havendo necessidade de gravar áudios tanto no período destinado à disciplina quanto nos contraturnos. A escola também ofereceu computadores para realização das atividades, mas muitos pais declararam não se sentir seguros para mandar os filhos para os atendimentos presenciais.

A opção por fazer as atividades da disciplina de Ciências de forma online, utilizando o Google Formulários (GOOLE ${ }^{1}$ ), fez com que muitas atividades já impressas pela secretaria da escola ficassem inutilizadas. Desta maneira, a direção escolar optou por imprimir as atividades apenas quando os alunos solicitassem, um indício de que é necessária uma flexibilização de acordo com as necessidades de cada aluno e não no que se acredita ser sua realidade por se tratar de uma escola pública. É claro que ainda há deficiências em seus aportes tecnológicos, mas trata-se de um ambiente que não é estático, afinal possui um potencial significativo de seus frequentadores, seres reflexivos que compartilham desejos de sobrepujar muitos problemas (MARCON et al., 2020)

No meio de desafios a serem superados, a escola teve que lidar com o compartilhamento desenfreado de Fake News entre os alunos, até mesmo nos grupos de WhatsApp das turmas, no qual os professores eram administradores. Essa situação ocorreu em momentos próximos as férias "antecipadas", em que a Secretaria de Estado de Educação (SED-MS) determinou recesso em maio de 2020. A mensagens compartilhadas estavam centradas na possível de anulação de ano letivo e que não haveria reprovações se os alunos não entregassem as atividades. Essa situação evidencia que fatos como esse podem gerar conjunturas conflitantes na escola, nas quais concepções individuais podem ganhar uma proporção acima dos fatos (CORRÊA; CUSTÓDIO, 2018). Assim sendo, foram marcadas videoconferências para esclarecimento e denúncias de Fake News sobre essa temática, onde o corpo docente e a coordenação pedagógica orientaram os alunos e seus responsáveis. A direção também divulgou nas suas 
redes sociais esclarecimentos acerca do tema e suas implicações e propôs que as buscas ativas passassem a ser intensificadas. Conseguinte, os alunos com pendência nas atividades passaram a se preocupar mais com sua vida escolar.

Todos esses acontecimentos ao longo do ano 2020 contribuíram direta e indiretamente para que as porcentagens de entrega de atividades fossem correspondentes as médias das turmas, uma vez que os alunos obtiveram valores de notas próximas a 6 e entrega de atividades perto de $60 \%$ (Figura 1).

Figura 1 - Comparação entre atividades remotas entregues no ano e médias anuais da disciplina de Ciências no ano de 2020

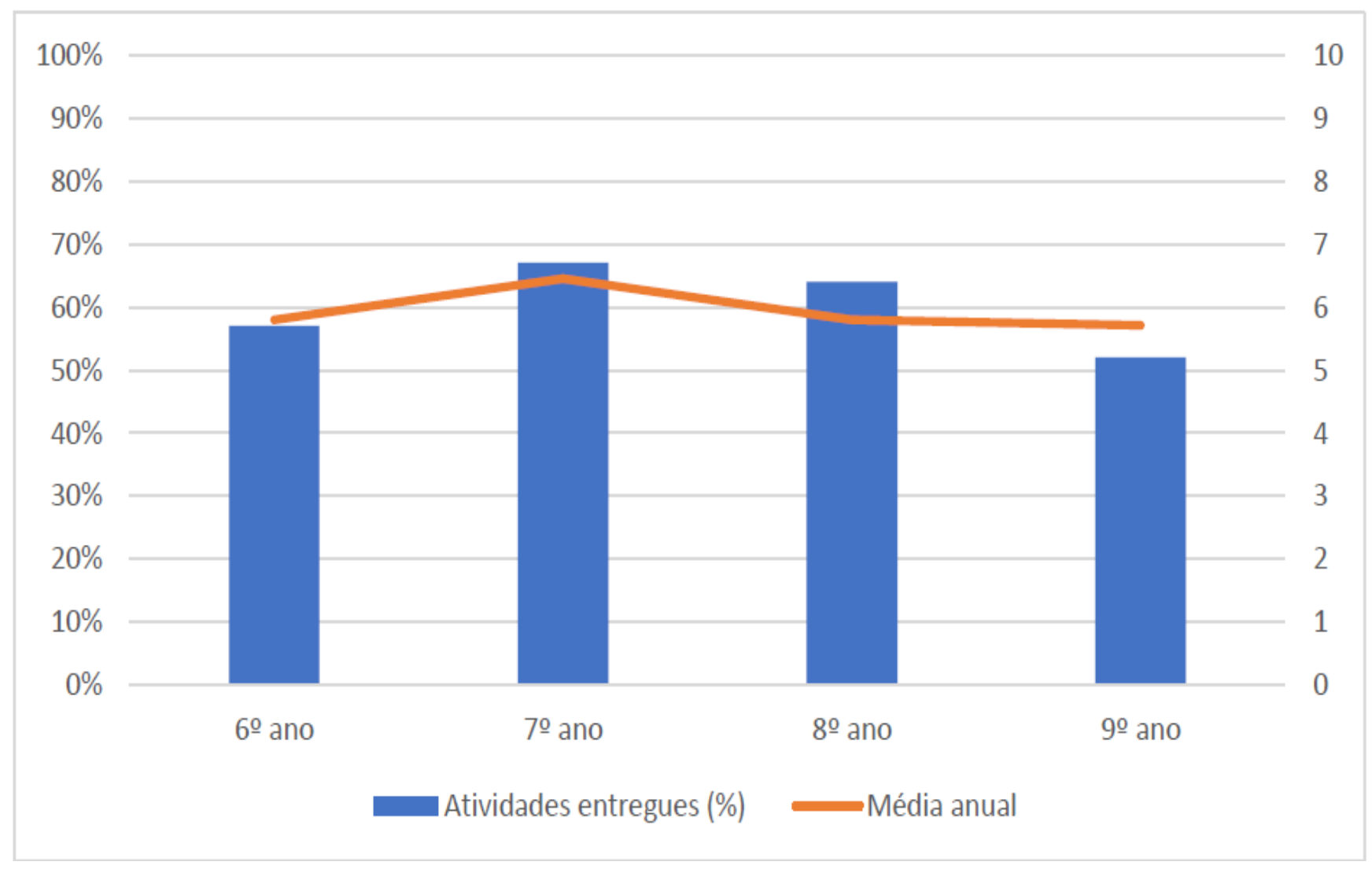

Fonte: Histograma elaborado pelos autores no programa Microsoft Excel 2016®

Apesar das médias obtidas e as atividades apresentarem uma certa regularidade durante o período letivo, nota-se que cada turma apresentou particularidades em resposta há alguns dos fatores apresentados anteriormente, condição que justifica as oscilações de notas e entregas de atividades ao longo dos bimestres. 
Na turma do $6^{\circ}$ ano, por exemplo, observou-se que os alunos nos dois primeiros bimestres tiveram desempenho regular entre atividades remotas entregues (médias da turma entre 6,5 e 6 ), porém apenas $46 \%$ deles entregaram a atividade completa no primeiro bimestre e $51 \%$ no segundo; no terceiro e quarto bimestre o número de atividades entregues aumentou, porém com médias reduzidas, com 5,8 e 4,9 respectivamente (Figura 2). A justificativa para as dificuldades foi apresentada por pais e alunos devido a maior dependência de acompanhamento nas atividades, revelando a carência de autonomia e dificuldade de interação com seus responsáveis. No segundo semestre a completude das atividades remotas foi maior, porém muitos alunos passaram a utilizar respostas vagas nas atividades, relatando que estavam com pressa para entregar e não leram com atenção. Evidencia-se também as preocupações dos alunos com pendência de atividades e notas necessárias para aprovação, condição que reforça que a quantidade de atividades entregues nem sempre condiz com a compreensão das mesmas.

Figura 2 - Porcentagem de atividades remotas entregues e médias anuais na disciplina de Ciências de alunos do $6^{\circ}$ ano

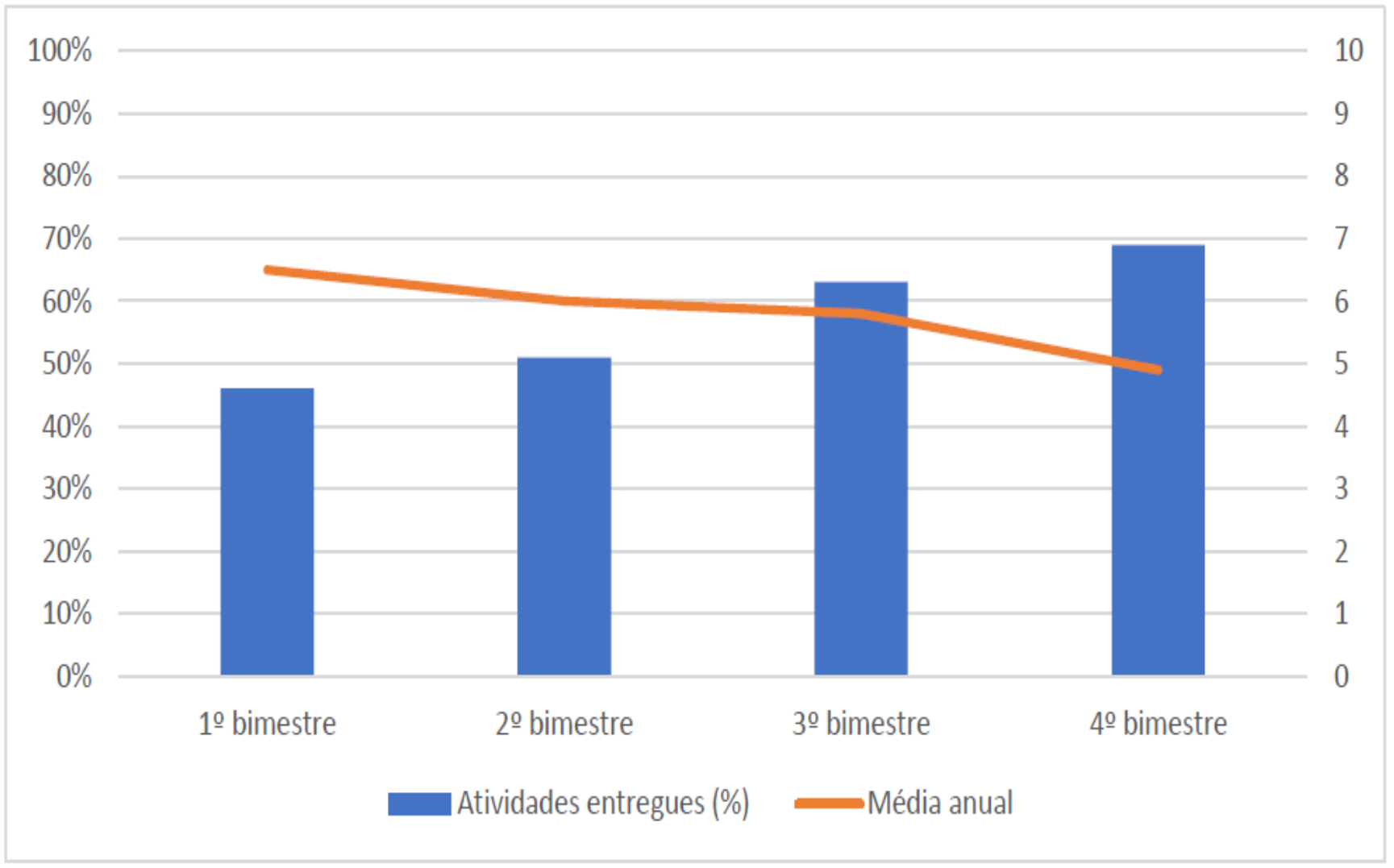

Fonte: Histograma elaborado pelos autores no programa Microsoft Excel 2016® 
A turma do $7^{\circ}$ ano foi a única das turmas que apresentou média acima de 6 e atividades entregues acima de $60 \%$ durante todo o ano letivo (Figura 3). Vale ressaltar que esta turma foi a única desse estudo que já havia tido contato com o professor no ano anterior a pandemia, situação que revelou maior confiança e proximidade com os alunos durante todo o período de aulas remotas. Também foi a turma que mais interagiu nas plataformas, videoaulas disponibilizadas e por meio de mensagem privadas no WhatsApp. Os pais dessa turma, em especial, apreciaram as videoaulas produzidas e contactavam com frequência o professor de Ciências para agradecer pelas aulas e verificar a situação dos alunos antes dos fechamentos de notas.

Figura 3 - Porcentagem de atividades remotas entregues e médias anuais de ciências dos alunos do $7^{\circ}$ ano

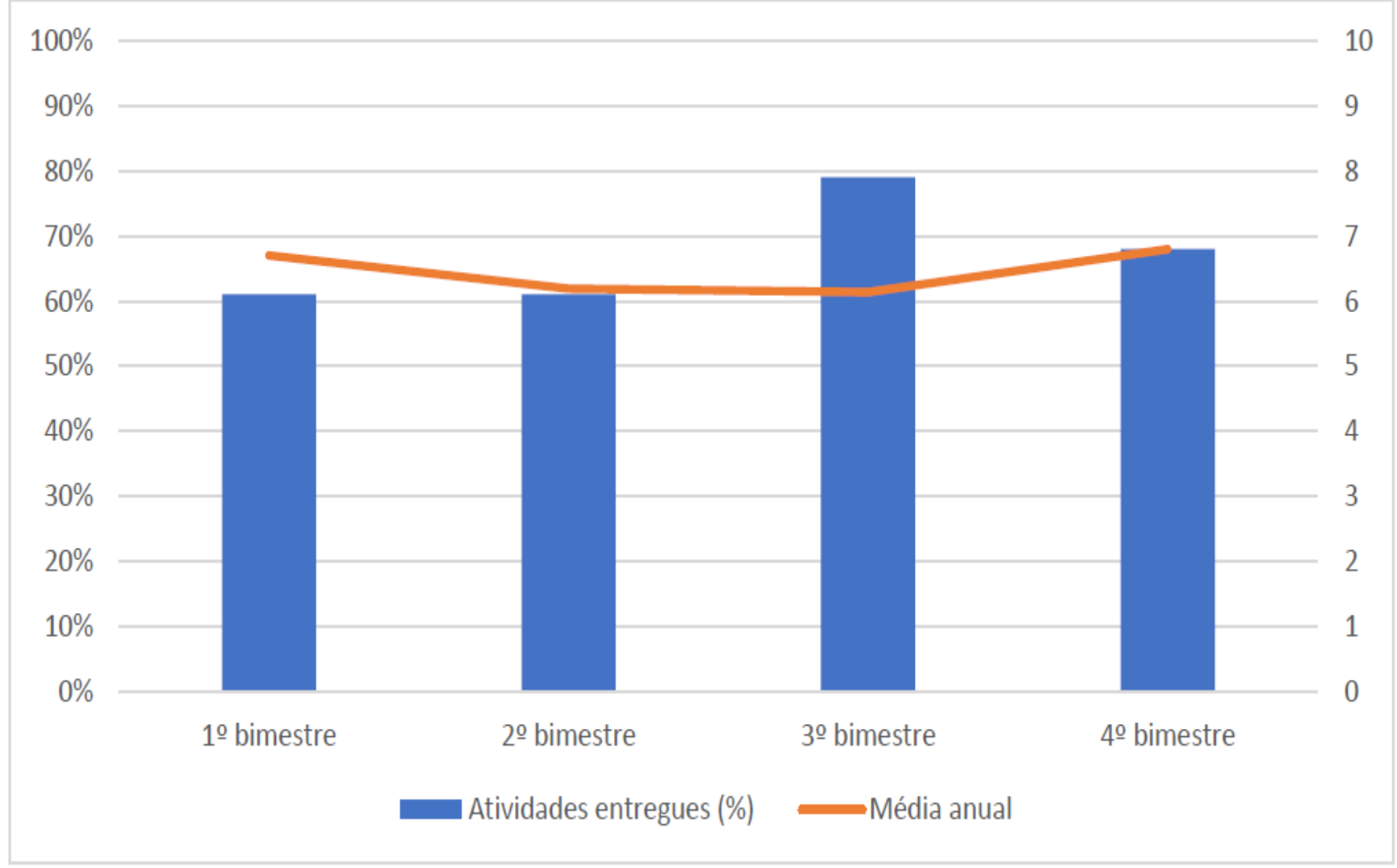

Fonte: Histograma elaborado pelos autores no programa Microsoft Excel 2016®

O $8^{\circ}$ ano teve cumprimento inicial das atividades superior a $70 \%$, valor que decresceu repentinamente no segundo bimestre (40\%). O motivo justificado pelos próprios alunos foi acreditar na ampla divulgação de Fake News sobre anulação do ano letivo e a impossibilidade de reprovação. De fato, o grupo de 
Whatsapp da turma foi o que mais apresentou divulgação de notícias falsas relacionadas a esses assuntos. Essa situação levou a novas intervenções por parte da coordenação pedagógica em momentos pós-conselhos de classe. A partir dessa ação, foi observada uma reação positiva por parte dos alunos, refletindo na entrega de atividades e médias nos bimestres subsequentes. Porém, os reflexos dessa lacuna entre os segundo e terceiro bimestres foram refletidos nas notas dos alunos e a quantidade de atividades entregues não foi proporcional as médias no terceiro bimestre. A situação só melhorou no quarto bimestre, quando já era do conhecimento dos alunos as notas necessárias para aprovação sem necessidade de exame final.

Figura 4 - Porcentagem de atividades remotas entregues e médias anuais de ciências dos alunos do $8^{\circ}$ ano

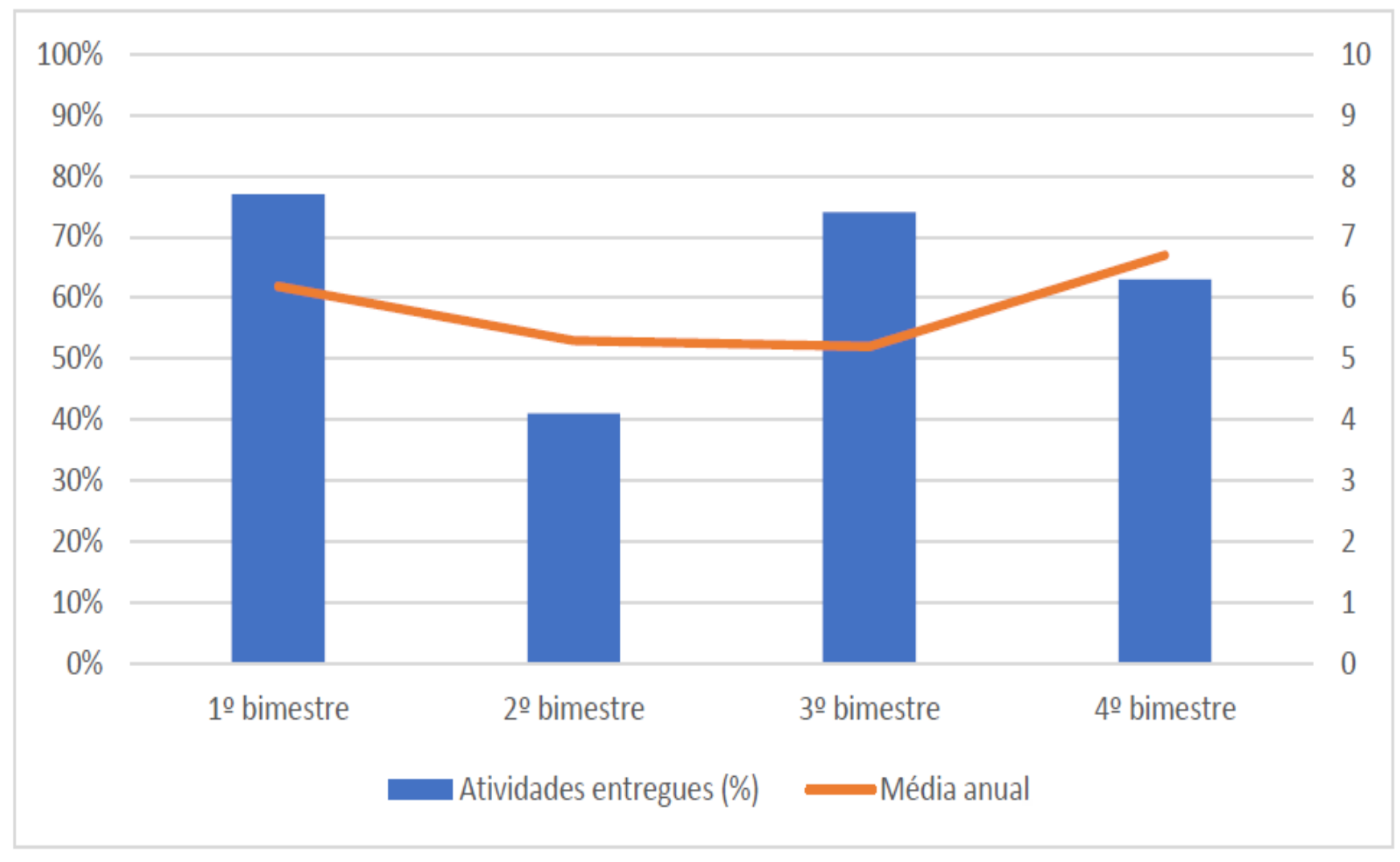

Fonte: Histograma elaborado pelos autores no programa Microsoft Excel 2016®

O $9^{\circ}$ ano foi a turma que apresentou mudanças mais significativas nos resultados desde o início das atividades, partindo de uma média abaixo de 6 no primeiro bimestre e apenas $30 \%$ das atividades entregues, seguidos aumentos de $10 \%$ e $24 \%$ nas entregas de atividades no segundo e terceiro bimestre, ocasionando aumento na média da turma (Figura 5). Essas variações podem estar 
associadas pelo fato da turma conter alunos repetentes e com baixo rendimento em anos anteriores ao período de aulas remotas. Nesse caso, algumas notas mais altas em casos isolados foram influenciadoras da média geral da turma, mas não suficiente para ocultar a dificuldade da turma nos bimestres iniciais do ano letivo.

As buscas ativas na turma do $9^{\circ}$ ano foram as mais frequentes entre as turmas amostradas, fazendo-se necessárias visitas presenciais da coordenação pedagógica nas residências dos alunos. Também foi preciso reabrir os diários após conselho de classe para substituir a opção "sem nota" pelas notas obtidas em atividades atrasadas.

Figura 5 - Porcentagem de atividades remotas entregues e médias anuais de ciências dos alunos do $9^{\circ}$ ano

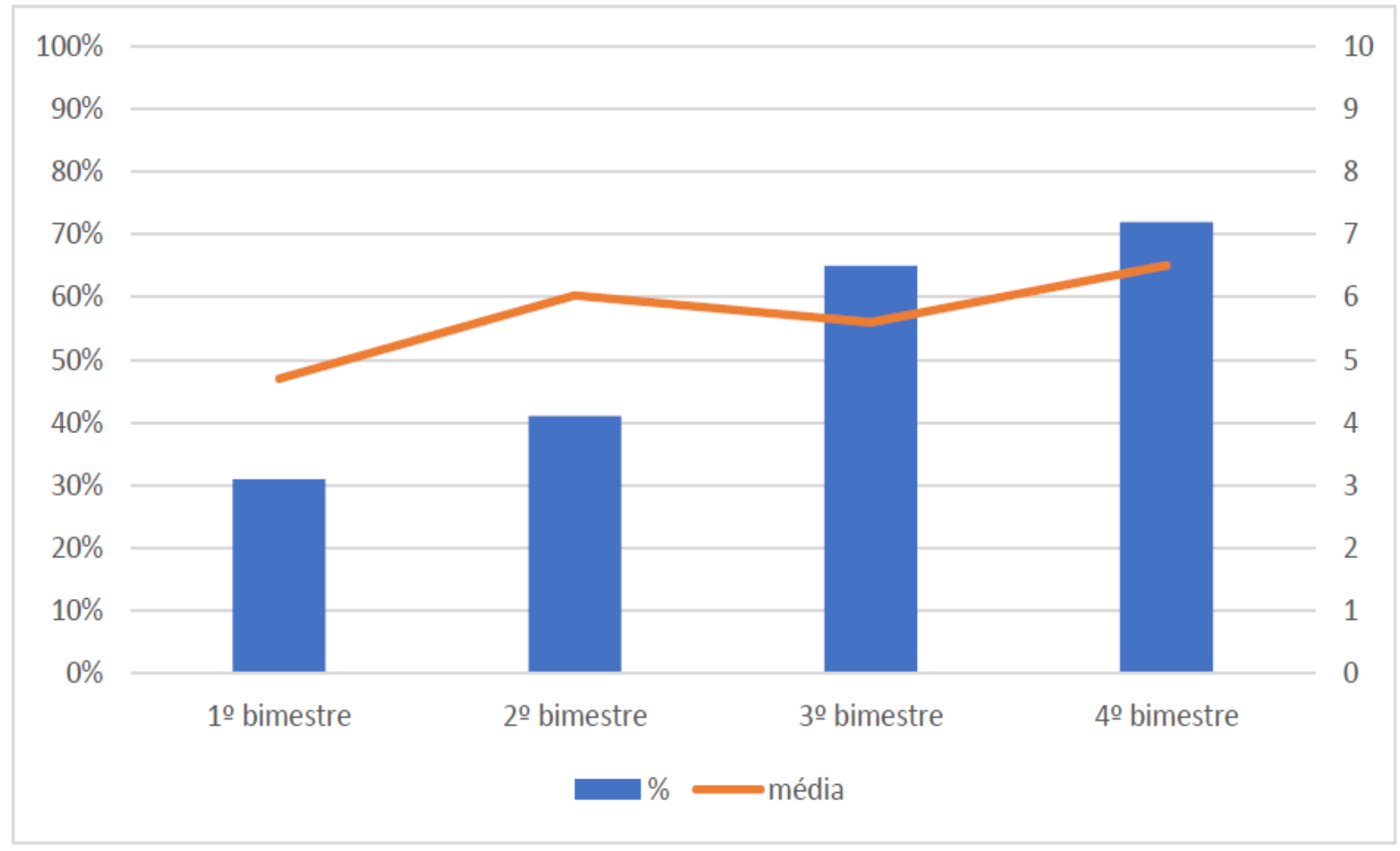

Fonte: Histograma elaborado pelos autores no programa Microsoft Excel 2016®

Diante das situações reveladas pela entrega e notas obtidas pelas atividades remotas da disciplina de Ciências, foram necessárias diversas intervenções por bimestre para orientar os alunos em questões que deveriam ser refeitas. Ainda assim, muitos alunos demonstraram interesse em entregar atividades atra- 
sadas de outras disciplinas ao invés de melhorar as médias de ciências. No caso dos alunos que concluíram as atividades com médias acima da turma houve a possibilidade de realizar atividades de outras disciplinas em que apresentavam mais dificuldades. Essas situações revelam a particularidade de cada aluno e a possibilidade de desenvolver autogestão, permitindo um atendimento diferenciado e exclusivo para os que apresentaram dificuldades na execução de atividades.

Apesar das variadas dificuldades enfrentadas no ano de 2020, o desempenho dos alunos revela uma considerável apropriação e autonomia frente às ferramentas digitais voltadas para o ensino de ciências. Portanto, a inserção de novos recursos, incluindo os audiovisuais, ferramentas avaliativas digitais, atendimentos diferenciados voltados para particularidade do aluno e intervenções pedagógicas no que se diz respeito ao cumprimento de atividades são passos a serem dados durante e pós-pandemia não somente na disciplina de Ciências como em demais áreas do conhecimento. Afinal, as tecnologias de informação e a internet promoveram mudanças de paradigmas no aprendizado, oportunizando o acesso ao conhecimento independente do lugar ou hora, bem como o rompimento com o ensino tradicional no século 21 (SILABAN et al., 2020)

O desempenho dos alunos frente aos modelos de aprendizagem adotados durante o período pandêmico indica futuras adoções de aprendizagem combinada, que trazem como possibilidade a instrução de alunos pela comunicação dos ambientes online e offline, compartilhando saberes e designando tarefas (BONK; GRAHAM, 2006; RESIEN et al., 2020). Portanto, os professores devem estar preparados para o manuseio da tecnologia e suas repentinas mudanças, cenário reforçado pelas práticas educacionais requisitadas em períodos de COVID-19 (FISCHER et al., 2020; KORKMAZ; TORAMAN, 2020).

Dentre as estratégias para momentos futuros no que se diz respeito ao ensino de ciências, está a busca por informação e fundamentações contidas nas mais variadas fontes, principalmente nas que estarão centradas na aprendizagem e participação dos alunos. Destarte, poderão ser firmadas novas práticas pedagógicas e estratégias sustentadas por múltiplas perspectivas, considerando diferentes cenários e perfis de alunos (LEVRINI et al., 2019; LEVRINI et al., 2020). 


\section{CONCLUSÃO}

Os perfis de autonomia dos alunos foram variados na pandemia, indicando que a flexibilidade nas formas de entrega de atividades e canais de comunicação ajudaram a identificar as necessidades dos alunos na execução das atividades remotas de ciências.

Apesar de certos desafios, os alunos foram bem receptivos aos ambientes virtuais, indicando que os momentos pós pandemia podem não estar tão distantes da adoção de metodologias híbridas na disciplina de Ciências. Portanto, muitas aulas expositivas podem ser mais ocupadas por videoaulas e atividades remotas utilizando tecnologias, dando maior espaço a discussões e atendimentos diferenciados em encontros presenciais.

Em virtude das situações vivenciadas no presente trabalho, consideramos que em momentos futuros será possível adotar futuramente estratégias e ferramentas mistas para o ensino de ciências nas turmas de ensino fundamental selecionadas, ainda que recursos tecnológicos possam ser fatores limitantes em algumas realidades, por exemplo, naquelas que revelam a falta de acesso à internet.

\section{REFERÊNCIAS}

BACICH, L.; NETO, A. T.; TREVISANI, F. De M. Ensino híbrido: personalização e tecnologia na educação. Porto Alegre: Penso Editora, 2015.

BACICH, L.; MORAN, J. Metodologias ativas para uma educação inovadora: uma abordagem teórico-prática. Penso Editora, 2018.

BONK, C.J.; GRAHAM, C.R. The handbook of blended learning environments: Global perspectives, local designs. San Francisco, California: Jossey-Bass/ Pfeiffer, 2006.

BERGMANN, J.; SAMS, A. Sala de aula invertida: uma metodologia ativa de aprendizagem. Rio de Janeiro: Livros Técnicos e Cientifios Editora Ltda, 2017. $141 \mathrm{p}$. 
DEMO, P. Marginalização digital: digital divide. Boletim Técnico do Senac, v.33, n.2. 2007.

GOOGLE¹. Google forms. Disponível em: <https://gsuite.google.com/signup/basic/welc ome?hl=pt-BR> Acesso em: 15 de março de 2020.

GOOGLE2. Google Classroom. Disponível em: <https://edu.google.com/prod ucts/classroom/?modal_active=none\#\%2Fready-to-go $>15$ de março de 2020.

BORBA, R. C.; R. C.; TEIXEIRA, P. P.; FERNANDES, K. D. O. B.; BERTAGNA, M.; VALENÇA, C. R.; DE SOUZA, L. H. P. Percepções docentes e práticas de ensino de ciências e biologia na pandemia: uma investigação da Regional 2 da SBEnBio. Revista de Ensino de Biologia da SBEnBio, p. 153-171. 2020.

BOUHNIK, D.; DESHEN, M. WhatsApp goes to school: Mobile instant messaging between teachers and students. Journal of Information Technology Education: Research, v. 13, n. 1, p. 217-231, 2014.

HORN, M. B.; STAKER, H. Blended: usando a inovação disruptiva para aprimorar a educação. Porto Alegre: Penso, 2015.

KORKMAZ, G.; TORAMAN, Ç. Are We Ready for the Post-COVID-19 Educational Practice? An Investigation into What Educators Think as to Online Learning. International Journal of Technology in Education and Science, v. 4, n. 4, p. 293-309, 2020.

LEVRINI, O., LEVIN, M.; FANTINI, P. Fostering appropriation through designing for multiple access points to a multidimensional understanding of physics. Physical Review Physics Education Research, v. 16, n. 2, p. 020154, 2020.

LEVRINI, O., LEVIN, M., FANTINI, P.; TASQUIER, G. Orchestration of classroom discussions that foster appropriation. Science Education, v. 103, n. 1, p. 206235, 2019.

MARCON, V; DA SILVA, V. C.; ERTHAL, A. Experiências de multiletramentos na escola pública: ensino híbrido, metodologias ativas e interdisciplinaridade. Revista Prâksis, v. 2, p. 87-102, 2020. 
MORÁN, J. Mudando a educação com metodologias ativas. Coleção Mídias Contemporâneas. Convergências Midiáticas, Educação e Cidadania: aproximações jovens, v. 2, n. 1, p. 15-33, 2015

FILHO, L. A. C. de R.; PEREIRA, M. V.; VAIRO, A. C. Recursos Audiovisuais como temática de pesquisa em periódicos brasileiros de Educação em Ciências. Revista Brasileira de Pesquisa em Educação em Ciências, v. 11, n. 2, p. 183204, 2011.

FISCHER, G.; LUNDIN, J.; LINDBERG, J. O. J. Rethinking and reinventing learning, education and collaboration in the digital age-from creating technologies to transforming cultures. The International Journal of Information and Learning Technology, 2020.

DI SORBO, A.; PANICHELLA, S.; ALEXANDRU, C. V.; SHIMAGAKI, J.; VISAGGIO, C. A.; CANFORA, G.; GALL, H. C. What would users change in my app? summarizing appreviews for recommending software changes. In: Proceedings of the 2016 24th ACMSIGSOFT International Symposium on Foundations of Software Engineering, p. 499-510, 2016.

CORREAA, E. C. D. Custódio, M. G. A informação enfurecida e a missão do bibliotecário em tempos de pós-verdade: uma releitura com base em Ortega y Gasset. Revista Brasileira de Biblioteconomia e Documentação, v. 14, n. 2, p. 197-214, 2018.

RESIEN, C.; SITOMPUL, H.; SITUMORANG, J. The effect of blended learning strategy and creative thinking of students on the results of learning information and communication technology by controlling prior knowledge. Budapest International Research and Critics in Linguistics and Education (BirLE), v. 3, n. 2, p. 879-893, 2020.

DOS SANTOS, V. L. P.; PEREIRA, J. M. S.; MERCADO, L. P. L. WhatsApp: um viés online como estratégia didática na formação profissional de docentes. ETDEducação Temática Digital, v. 18, n. 1, p. 104-121, 2016.

SILABAN, P.S. M., SUHARIANTO, J.; RUSLAN, D. Development of macroeconomic theory materials based on blended learning. Budapest International Research and Critics in Linguistics and Education (BirLE) Journal, v. 3, n. 1, p. 88-98, 2020. 
UNESCO - Organização das Nações Unidas para a Educação, a Ciência e a Cultura. COVID-19: 10 Recommendations to plan distance learning solutions. Disponível em: https://en.unesco.org/news/covid-19-10-recommendations-plandistancelearning-solutions. Acesso em: 20 de Junho de 2021.

WHITE, R. Dimensions of Content. In: The content of science: a constructiist approach to its teaching and learning. London:The Falmer Press, p. 255-274, 1994. 
doi $10.48209 / 978-65-89949-13-9$

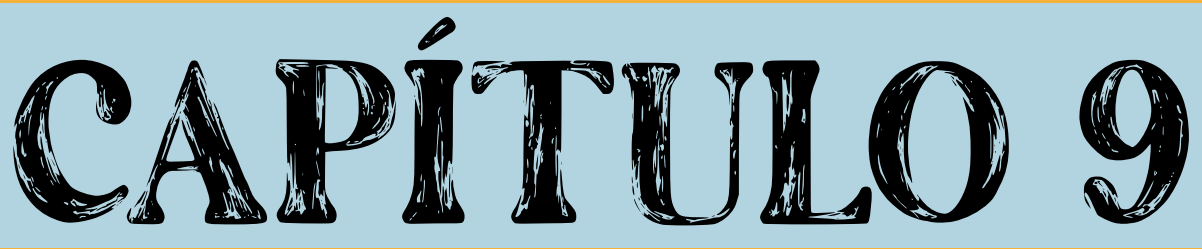

\section{ENSINO DAS GEOCIÊNCIAS EM TEMPOS DE PANDEMIA: REIATO DE EXPERIÊNCIA}




\section{INTRODUÇÃO}

Entre o final do ano de 2019 e início de 2020, a humanidade foi pega de surpresa por uma pandemia de proporções até então inimagináveis, causada pelo novo coronavírus: o COVID-19 (Sars-Cov-2). Este novo vírus se espalhou rapidamente por todo o planeta Terra, impondo ao mundo a tomada de medidas críticas para o controle de sua disseminação. Neste sentido, uma das áreas fortemente atingidas foi a da educação pública, o que fez com que os seus profissionais, juntamente com as suas instituições de ensino, se adequassem rapidamente ao momento, buscando novas estratégias e ferramentas para cumprir à sua função perante a sociedade (VASCONCELLOS et al., 2020).

Em meio ao caos sanitário que se instalou no Brasil, as Instituições de Ensino Superior (IES), por sua vez, buscaram reorganizar suas atividades e infraestruturas para atender às novas demandas que surgiram neste período, como forma de reafirmar o compromisso de cada uma com a resolução dos mais diversos problemas sociais (GIMENEZ et al., 2020).

Isto não ocorreu de forma diferente no Instituto Federal de Educação, Ciência e Tecnologia do Pará (IFPA), especificamente no Campus Bragança, local onde as turmas que serão relatadas no decorrer deste artigo, frequentavam as aulas de forma presencial até meados de março de 2020, quando as atividades presenciais foram suspensas. Muitos foram os percalços e dificuldades identificadas no processo ensino-aprendizagem, por representar uma situação nunca antes vivenciada pelos atores que compunham e compõem a instituição de ensino em questão.

Diante do exposto, o presente artigo tem como objetivo relatar as experiências e resultados obtidos por meio da oferta remota de disciplinas que englobam o campo das Geociências, que, segundo a Fundação Oswaldo Cruz (FIOCRUZ), abrangem disciplinas científicas que estudam o planeta Terra, por meio da análise de rochas, atmosfera, placas tectônicas, oceanos, dentre outras composições terrestres. O que é o caso da Geologia, disciplina que integra este vasto rol. 
Para atingir este objetivo, foram utilizadas as disciplinas de Geologia Ambiental e de Fundamentos de Geologia, pertencentes às grades curriculares do curso superior de Tecnologia em Gestão Ambiental e do curso de Licenciatura em Geografia, respectivamente, na intenção de expor as metodologias utilizadas, dificuldades encontradas e explanar o que foi alcançado de positivo por meio das atividades desenvolvidas remotamente.

\section{LOCAL DE PESQUISA}

Como já citado no tópico anterior, as turmas a serem relatadas neste artigo, são turmas do curso superior de Tecnologia em Gestão Ambiental e do curso de Licenciatura em Geografia, ambas ofertadas pelo IFPA/Campus Bragança.

O IFPA/Campus Bragança está situado na cidade de Bragança, estado do Pará, Brasil. A cidade de Bragança, por sua vez, localiza-se na mesorregião Nordeste Paraense e microrregião Bragantina (IBGE, 2020b), sob o par de coordenadas plana UTM (Universal Transversa de Mercator) 9883488 Norte (N) e 303539 Leste $(E)$, fuso 23M.

O município foi fundado em 08 de julho de 1613, possuindo extensão territorial de cerca de $2.124,734 \mathrm{~km}^{2}$ e uma população estimada de aproximadamente 128.914 habitantes para o ano de 2020 (IBGE, 2020a; IBGE, 2020c) (figura 1).

\section{SUSPENSÃo dAS ATIVIDADES PRESENCIAIS dE SALA DE AULA}

O IFPA/Campus Bragança encontra-se com suas atividades presenciais de sala de aula suspensas desde março de 2020, devido a disseminação da pandemia do COVID-19. Essa suspensão perdura até os dias atuais, junho de 2021, e ainda não há uma data estipulada para o retorno presencial. 
Figura 1 - Mapa de localização do IFPA/Campus Bragança, enfatizando a área construída.

\section{LOCALIZAÇÃO IFPA/CAMPUS BRAGANÇA}
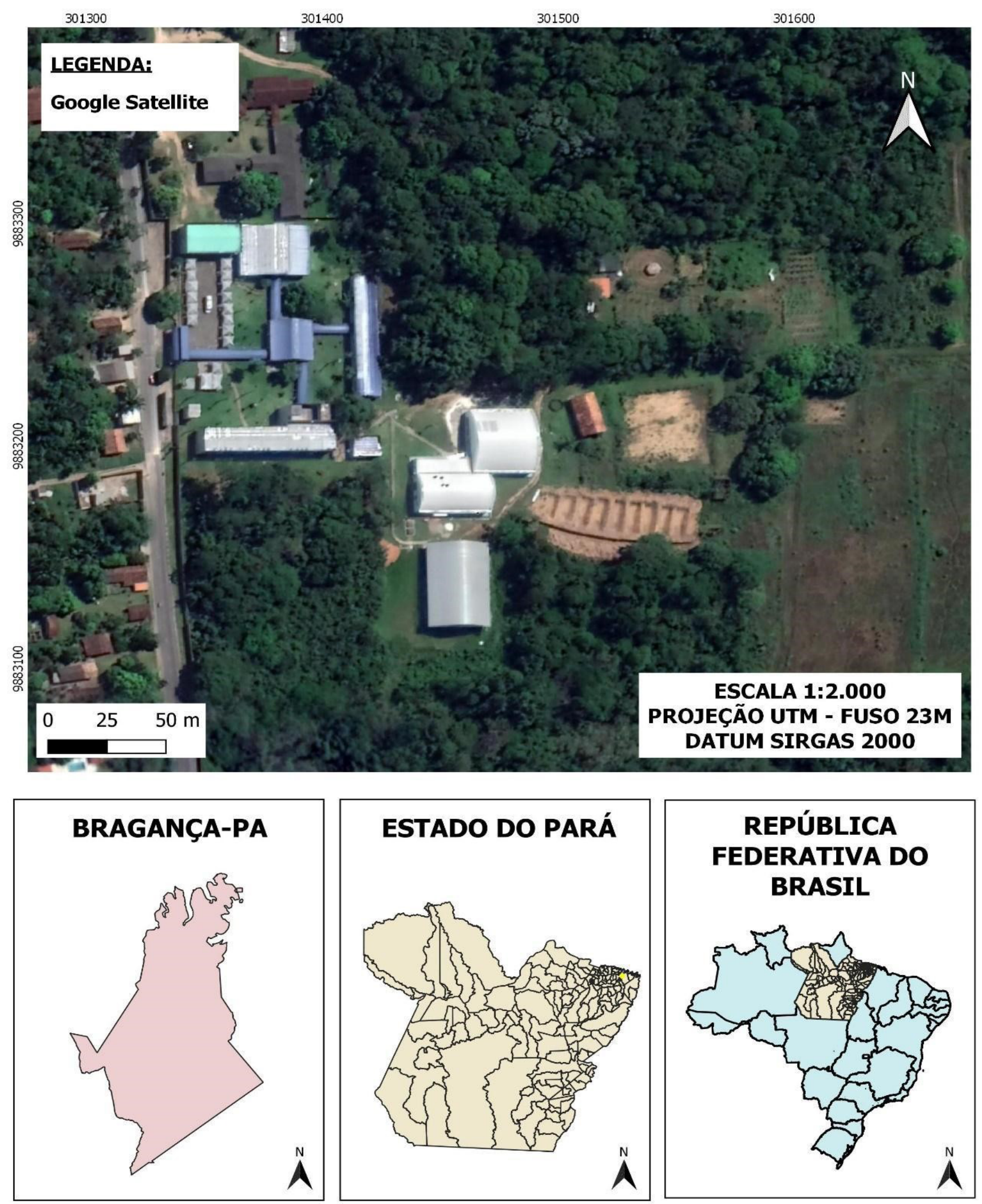

Fonte: autoria própria. 
Desta forma, o campus necessitou se reinventar e se adaptar o mais rapidamente a essa situação pandêmica, como forma de cumprir a sua função de promover um ensino gratuito e de qualidade para a sociedade bragantina e de se consolidar como referência na região. A saída então, foi a continuidade das atividades de sala de aula de forma remota.

Como os docentes do referido campus, bem como os discentes, no geral, não possuíam experiência consolidada para desenvolverem suas atividades por meio do ensino remoto, foi promovido pela Pró-reitoria de Ensino (PROEN) do IFPA, o projeto de ensino intitulado: "As Tecnologias de Informação e Comunicação (TIC's) nos Processos de Ensino Aprendizagem”, ofertado durante os meses de abril e maio de 2020.

O projeto em questão consistiu em um esforço da PROEN, com apoio dos gestores do ensino dos campi do IFPA e docentes de cursos do eixo tecnológico Informação e Comunicação, assim como outros, no intuito de capacitar docentes e discentes na utilização das ferramentas que o Sistema Integrado de Gestão de Atividades Acadêmicas (SIGAA) dispunha para atividades remotas (IFPA, 2020c).

Após o período de capacitação por meio do projeto de ensino citado acima, iniciou-se um longo período de planejamento e pesquisa com os discentes como forma de compreender a situação de cada um e verificar a melhor forma de retornar às atividades de sala de aula remotamente.

Várias foram as reuniões entre os gestores dos cursos e do campus, com participação dos servidores em geral, bem como dos discentes matriculados nos cursos ofertados pelo IFPA/Campus Bragança, todas elas de forma remota, com auxílio das mais diversas ferramentas de TIC's, como, por exemplo, o aplicativo Google Meet e por meio de lives exibidas através da rede social Facebook.

Outra recurso utilizado pelo IFPA, como forma de atenuar os impactos causados pela pandemia do COVID-19, foi a publicação de edital do projeto Alunos Conectados que tem como objetivo promover suporte às ações emergenciais de educação, pesquisa e assistência ao ensino, em apoio ao enfrentamento da referida pandemia, por meio da disponibilização e monitoramento de chip/pacote de 
dados aos estudantes matriculados em cursos presenciais técnicos e de graduação, em condição de vulnerabilidade socioeconômica, para o desenvolvimento de atividades acadêmicas remotas (IFPA, 2020a; IFPA, 2021).

Como resultado de toda essa somatória de esforços, as atividades de sala de aula puderam retornar, para alguns cursos, de forma remota, já a partir de outubro de 2020. Atualmente, todos os cursos do campus Bragança vem funcionando regularmente por meio de atividades de sala de aula de forma remota.

Todas as disciplinas ofertadas remotamente, precisaram ter seu Plano de Disciplina Adaptado, submetido ao colegiado do respectivo curso, pelo professor responsável por ministrar a disciplina, para que assim pudesse obter aprovação. Se aprovado, o referido plano ainda passaria pela avaliação da Coordenação Pedagógica do campus, para a emissão de parecer técnico-pedagógico favorável, permitindo, desta forma, a oferta da disciplina remotamente.

\section{RELATO DE EXPERIÊNCIA}

\section{Metodologias para as atividades remotas}

A principal ferramenta para os momentos síncronos foi o aplicativo Google Meet, que tornou possível a realização das aulas ao vivo. Como o IFPA adquiriu o GSuite do Google, as aulas síncronas foram gravadas e disponibilizadas para todos os alunos matriculados na disciplina, principalmente para aqueles que não puderam acompanhar no primeiro momento.

Como forma de acompanhamento do dia-a-dia da turma, foram criados grupos no aplicativo WhatsApp para que os discentes pudessem retirar as dúvidas e para o envio dos materiais utilizados nas aulas. Todo o material utilizado, bem como o Plano de Aula Adaptado para a disciplina, após aprovado, foi disponibilizado no Sistema Integrado de Gestão de Atividades Acadêmicas (SIGAA).

O material das aulas foram sempre disponibilizados antes do momento síncrono, para que todos tivessem a oportunidade de se empoderar sobre o que seria tratado na aula e praticassem o processo de flipped classroom (sala de aula invertida). 


\section{Disciplina Geologia Ambiental para o curso de Tecnologia em Gestão Ambiental}

O curso superior de Tecnologia em Gestão Ambiental retornou às suas atividades de sala de aula remotamente em meados de outubro de 2020 e a disciplina de Geologia Ambiental foi ofertada durante os meses de dezembro de 2020 a janeiro de 2021 .

A disciplina é composta por uma carga horária de 48 horas/aulas (h/a), destas, $15 \mathrm{~h} / \mathrm{a}$ foram ministradas presencialmente, antes da suspensão das aulas presenciais, restando $33 \mathrm{~h} / \mathrm{a}$ a serem ministradas remotamente. Os assuntos que constam na ementa da disciplina são: constituição do globo terrestre, minerais e rochas, intemperismo, a ação dos ventos, água subterrânea, geomorfologia do Pará, mapa geológico do Pará, sensoriamento remoto e fotogeologia e prática de campo (IFPA, 2016).

A avaliação ocorreu de forma continuada baseada na participação síncrona e assíncrona, de acordo com a realidade particular de cada aluno, e por meio das realizações das atividades postadas no SIGAA, como questionários e listas de exercícios. Cada uma dessas atividades aplicadas foram levadas em consideração para compor as notas referentes ao $1^{\circ}$ e $2^{\circ}$ bimestres dos alunos.

Para a avaliação do $1^{\circ}$ bimestre foram levadas em conta a resolução das atividades cadastradas no SIGAA referentes ao temas: minerais e rochas, bem como o envio por e-mail de atividade referente ao tema geologia e geomorfologia do Pará. Já para o $2^{\circ}$ bimestre foram cadastradas no SIGAA atividades referentes aos temas: intemperismo, ação dos ventos e água, água subterrânea, sensoriamento remoto e fotogeologia.

Ao todo a turma continha 27 alunos matriculados, destes, 20 foram aprovados, alcançado notas superiores a nota mínima para aprovação no IFPA, o que representa uma porcentagem de mais de $74 \%$ de aprovação dos alunos matriculados. No total, 7 alunos reprovaram, dentre estes, 4 sequer compareceram às atividades, 2 reprovaram por nota e falta e 1 reprovou por nota apenas. 


\section{Disciplina Fundamentos Geologia para o curso de Licenciatura em Geografia}

O curso de Licenciatura em Geografia retornou às suas atividades de sala de aula remotamente em meados de novembro de 2020 e a disciplina de Fundamentos em Geologia foi ofertada durante o mês de janeiro de 2021. A disciplina é composta por uma carga horária de 48 h/a, destas, 8 h/a foram ministradas presencialmente, antes da suspensão das aulas presenciais, restando $40 \mathrm{~h} / \mathrm{a}$ a serem ministradas remotamente.

A sua ementa é composta pelas disciplinas: constituição do globo terrestre, tectônica de placas, minerais formadores de rocha, tipos de rochas: rochas ígneas, metamórficas e sedimentares, a dinâmica interna: magma, vulcanismo, plutonismo e terremotos, e externa: epirogênese e orogênese, intemperismo e erosão, ação dos ventos, rios e gelo, o tempo geológico, navegação com bússola e por receptor de sinal de satélite, prática de campo e manipulação de mapas analógicos e digitais (IFPA, 2019).

Por sua vez, a avaliação da aprendizagem ocorreu de forma contínua, também baseada na participação síncrona e assíncrona, de acordo com a realidade particular de cada aluno, e por meio das realizações das atividades postadas no SIGAA, como questionários e listas de exercícios. Cada uma dessas atividades aplicadas foram levadas em consideração para compor as notas referentes ao $1^{\circ}$ e $2^{\circ}$ bimestres dos alunos.

Para a avaliação do $1^{\circ}$ bimestre foram levadas em conta a resolução das atividades cadastradas no SIGAA referentes ao temas: constituição do globo terrestre, tectônica de placas e dinâmica interna da Terra e minerais formadores de rochas, bem como o envio por e-mail de atividade referente ao tema: o tempo geológico. Já para o $2^{\circ}$ bimestre foram cadastradas no SIGAA atividades referentes aos temas: tipos de rochas: rochas ígneas, rochas sedimentares e rochas metamórficas, dinâmica externa da Terra: intemperismo e erosão, ação dos ventos, rios e gelo e navegação com bússola e por receptor de sinal de satélite. 
Ao todo a turma continha 30 alunos matriculados, destes, 19 foram aprovados, alcançado notas superiores a nota mínima para aprovação no IFPA, o que representa uma porcentagem de mais de $63 \%$ de aprovação dos alunos matriculados. No total, 11 alunos reprovaram e sequer compareceram às atividades.

\section{Comparativo entre as duas turmas analisadas}

Ambos os cursos, Tecnologia em Gestão Ambiental e Licenciatura em Geografia, apesar das dificuldades encontradas, conseguiram retornar às aulas de forma remota ainda no ano de 2020, o primeiro em meados de outubro 2020 e o segundo em novembro do mesmo ano.

As disciplinas que envolvem conhecimentos de geociências nos cursos em questão, foram ministradas poucos meses após o retorno dos cursos remotamente. Para o curso de Tecnologia em Gestão Ambiental, a disciplina Geologia Ambiental foi ministrada durante os meses de dezembro de 2020 a janeiro de 2021, já para o curso de Licenciatura em Geografia, a disciplina de Fundamentos de Geologia ocorreu durante o mês de janeiro de 2021. Ambas são compostas por conteúdos similares e pela mesma carga horária, $48 \mathrm{~h} / \mathrm{a}$, das quais restavam 33 h/a serem ministradas para o curso de Tecnologia em Gestão Ambiental e 40 h/a para o curso de Licenciatura em Geografia.

As metodologias de ensino voltadas para as atividades a serem desenvolvidas remotamente foram bem parecidas no geral, fazendo uso das mesmas ferramentas, permitindo, desta forma, uma comparação entre os resultados alcançados nas duas turmas em questão.

O índice de aprovação da turma do curso de Tecnologia em Gestão Ambiental foi de $74 \%$, onde 20 alunos dos 27 matriculados conseguiram alcançar êxito. Em relação ao curso de Licenciatura em Geografia, o índice foi um pouco menor, representando apenas $63 \%$ de aprovação, onde apenas 19 alunos foram aprovados, dentre os 30 que estavam matriculados na disciplina. 


\section{CONCLUSÕES}

As atividades de sala de aula desenvolvidas de forma remota, se mostraram uma boa saída como forma de enfrentamento ao contexto pandêmico que vivenciamos no mundo e no nosso país como um todo, o que acabou impossibilitando o desenvolvimento de aulas presenciais, devido às medidas sanitárias impostas pelo poder público. Todavia, a experiência em questão, nos demonstra as inúmeras dificuldades encontradas para o ensino remoto em instituições de ensino público, como é o caso do IFPA/Campus Bragança, pois, além das dificuldades corriqueiras que o ensino remoto nos impõe - como problemas de acesso e oscilações na internet, ausência de hardwares pessoais (computadores e/ ou laptops, por exemplo) e softwares específicos instalados nos mesmos, falta de prática com as ferramentas remotas por boa parte dos discentes e também docentes -, ainda nos deparamos com situações mais comuns em escolas públicas, como é o caso da situação de vulnerabilidade socioeconômica dos alunos.

As instituições de ensino públicas devem zelar pela permanência dos seus discentes matriculados, honrando com o seu compromisso em oferecer um ensino público, gratuito e de qualidade, nos moldes da Constituição Federal do país (BRASIL, 1988) e legislações posteriores, o que não deve ocorrer de forma diferente no IFPA/Campus Bragança.

O relatado acima ilustra o motivo dos inúmeros diálogos que ocorreram antes da decisão do retorno das atividades de sala de aula de forma remota no referido campus, pois o intuito primordial era a preservação dos alunos nos cursos ofertados e diminuição ao máximo dos possíveis índices de evasão futuros. Isso fica bem claro quando o IFPA permitiu, por meio da Instrução Normativa $n^{\circ}$ 03/2020-PROEN/IFPA (IFPA, 2020b), que aqueles alunos que, por algum motivo, não pudessem assistir às aulas, trancassem o curso ou até mesmo um ou mais dos componentes curriculares, em qualquer momento do curso, sem prejuízo algum ao aluno e com a garantia de oferta das disciplinas quando do retorno presencial. 
Em relação às disciplinas da área de geociências, Geologia Ambiental e Fundamentos de Geologia, as maiores dificuldades encontradas foram em relação a impossibilidade da realização de atividades práticas presenciais, principalmente as práticas de campo, algo de extrema relevância para a geologia como ciência, onde os discentes têm a possibilidade de reconhecer os diferentes tipos de rochas e suas estruturas, além de utilizar equipamentos inerentes ao dia-a-dia da geologia, o que representa um imenso prejuízo no processo ensino-aprendizagem.

O que fica de mais expressivo dessa experiência, é que o ensino remoto foi uma solução encontrada para enfrentar a pandemia em que estamos vivendo, porém, não tem a capacidade, pelo menos com o que temos em mãos atualmente, de substituir completamente as aulas presenciais em uma instituição de ensino público. Isso é fácil de perceber nas recorrentes falas e reclamações dos alunos, professores e demais profissionais da educação no decorrer da prática do ensino remoto. Por outro lado, a tendência para o cenário pós-pandemia, é que muitas dessas ferramentas utilizadas como facilitadoras do ensino remoto e que de certa forma "encurtaram" as distâncias geográficas, possam permanecer e serem agregadas ao ensino presencial, permitindo a interação com profissionais de outras localidades do país e/ou até do mundo, aumentando a possibilidade de troca de experiências e materiais entre docentes e discentes.

\section{REFERÊNCIAS}

BRASIL. Constituição Federal. 1988. Disponível em: http://www.planalto.gov. br /ccivil_03/constituicao/constituicaocompilado.htm/. Acessado em: 29/06/2021.

FIOCRUZ. O que é geociências?. [s. d.]. Disponível em: http://www.juventudect .fiocruz .br/geociencias/. Acessado em: 20/06/2021.

GIMENEZ, A. M. N.; SOUZA, G.; FELTRIN, R. B. Para além do ensino, da pesquisa e da extensão: iniciativas e respostas das universidades brasileiras para o enfrentamento da COVID-19. Revista Tecnologia e Sociedade, vol. 16, n 43, 2020. DOI: 10.3895/rts.v16n43.12401. 
IBGE. Áreas Territoriais. 2020a. Disponível: https://www.ibge.gov.br/geocienci as/organizacao-do-territorio/estrutura-territorial/15761-areas-dos-municipios.ht $\mathrm{ml}$ ?=\&t=o-que-e/. Acessado em: 20/06/2021.

IBGE. Divisão Territorial Brasileira - DTB. 2020b. Disponível em: https://www. ibge.gov.br/geociencias/organizacao-do-territorio/estrutura-territoria 1/23701-divisao-territorial-brasileira.html?=\&t=o-que-e/. Acessado em: 20/06/2021.

IBGE. Estimativas da População. 2020c. Disponível em: https://www.ibge.gov. br/estatisticas/sociais/populacao/9103-estimativas-de-pop ulacao.html?=\&t=0-que-e/. Acessado em: 20/06/2021.

IFPA. Edital nº 05/2021 - Seleção de estudantes para atendimento com chip/ pacotes de dados de internet (dados móveis) pelo projeto Alunos Conectados/MEC/RNP. Reitoria/IFPA, Belém-PA, 2021.

IFPA. Edital $n^{\circ}$ 07/2020 - Seleção de estudantes para atendimento com chip/ pacotes de dados de internet (dados móveis) pelo projeto Alunos Conectados/MEC/RNP. Reitoria/IFPA, Belém-PA, 2020a.

IFPA. Instrução Normativa n 03/2020-PROEN/IFPA - Instrui sobre procedimentos e fluxos de registros acadêmicos decorrentes do Regulamento de Atividades de Ensino Remotas nos Cursos de Educação Básica e Profissional e Cursos Superiores de Graduação do Instituto Federal do Pará (IFPA) para o ano acadêmico de 2020, no contexto da pandemia do novo coronavírus, aprovado pela Resolução $n^{\circ}$ 110/2020-CONSUP, de 20 de julho de 2020. PROEN/IFPA, Belém-PA, 2020b.

IFPA. Projeto de Ensino: As Tecnologias de Informação e Comunicação nos Processos de Ensino Aprendizagem. 2020c. Disponível em: https://sigaa. ifpa.edu.br/sigaa/public/comunidadesDeProjetosDeEnsino;jsessionid=78DD0B113F01982B23D117D9B4F210F.node1default/. Acessado em: 20/06/2020.

IFPA. Projeto Pedagógico do Curso de Licenciatura em Geografia. IFPA/ Campus Bragança, Bragança-PA, 2019.

IFPA. Projeto Pedagógico do Curso Superior de Tecnologia em Gestão Ambiental. IFPA/Campus Bragança, Bragança-PA, 2016.

VASCONCELLOS, R. P. M.; SILVA, C. B.; SOUZA, C. H. M.; LUNA, P. C. C.; MACIEL, P. C. S. Reflexões sobre o uso de tecnologias digitais em tempos de pandemia na educação básica da rede pública de ensino. In: JORGE, W. J. (org). Educação presencial e a distância: Desafios e reflexões. Uniedusul, cap. 06, 2020. 
doi $10.48209 / 978-65-89949-10-8$

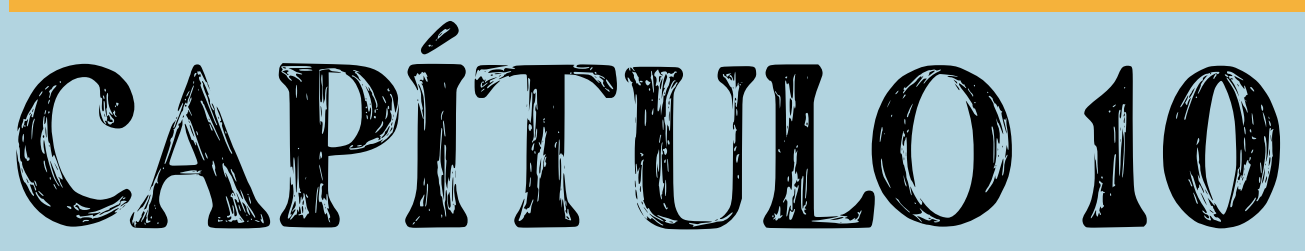

A ABORDAGEM CTS NO ENSINO DE BIOLOGIA: USANDO 0 MOVIMENTO ANTIVACINA COMO QUESTÃO NORTEADORA

\author{
Elaine Lima Silva \\ Rita de Cássia Frenedozo \\ Rosione Maria dos Santos Rodrigues \\ Tatiane Tenuta de Andrade \\ Vera Maria Jarcovis Fernandes
}




\section{INTRODUÇÃO}

As escolas brasileiras são instituições de ensino que tradicionalmente têm uma forte ligação com a comunidade. Desta forma, o currículo escolar do Ensino Médio é fundamental para oferecer debates, com objetivo de desempenhar adequadamente o papel de formação de cidadãos, assim como, o ensino de Biologia é um dos Componentes Curriculares que merecem atenção para que os alunos sejam capazes, não só compreender, mas aprofundar conceitos biológicos e suas tecnologias trazendo discussões e fomentando a alfabetização cientifica.

As temáticas envolvendo vírus e produção de vacinas são assuntos em destaque desde o início de 2020 devido à situação pandêmica, neste cenário, é no ensino da Biologia, à luz do conhecimento científico, que os alunos, buscam compreender a doença, as causas, os efeitos e a prevenção.

\section{Segundo Carvalho, (2020)}

O novo coronavírus, descoberto em dezembro de 2019, recebeu o nome de SARS-CoV-2 (sigla do inglês que significa coronavírus 2 da síndrome respiratória aguda grave), cuja doença recebeu a denominação pela Organização Mundial da Saúde (OMS) de COVID-19 (do inglês coronavírus disease 19).

A pandemia causada pelo Coronavírus é um dos marcos históricos do século $\mathrm{XXI}$, devido a sua gravidade promoveu a corrida em busca de uma nova vacina a fim de controlar a doença. As infecções provocadas por vírus e bactérias são tão antigas quanto à própria humanidade. Cavalheiro (2008), menciona: "as doenças transmissíveis dominaram a história, havendo estudos de paleoparasitologia que permitem descrever sua distribuição pré-histórica".

A identificação do primeiro vírus ocorreu aproximadamente, há 122 anos, com o estudo do vírus do mosaico de Tabaco (TMV). "O conhecimento mais detalhado sobre as particularidades biológicas e físico-químicas só foi possível com o avanço da tecnologia e a utilização do Microscópio Eletrônico por volta de 1930 (JARED, 2015; CREAGER, 2002)". Essa dificuldade se deu por se tratar de um microrganismo 100 vezes menor do que uma bactéria. 
Desde que a pandemia da Covid-19 chegou ao Brasil, em fevereiro de 2020, as discussões sobre Educação a Distância (EaD) e ensino remoto emergencial têm ocupado a cena e recebido maior destaque na área da educação. Professores e alunos de todos os níveis de ensino tiveram que se adaptar a uma nova realidade. E não foi diferente para o ensino da disciplina Biologia, em que os professores tiveram que repensar a sua práxis no ambiente virtual, já que percebiam um grande abismo entre o ensino presencial e o remoto.

A portaria MEC 544 de 2020 (BRASIL, 2020), estendeu as aulas remotas até o fim do ano, e autorizou o uso de recursos educacionais digitais e Tecnologias Digitais de Informação e Comunicação (TDIC). O fato é que, frente à impossibilidade de realização de aulas presenciais, as instituições de educação que atendem aos diferentes níveis de ensino (Básico ou Superior), se viram diante de um impasse: suspender as atividades ou mantê-las, na medida do possível, remotamente.

Neste cenário, uma aprendizagem contextualizada e significativa aos discentes sobre a pandemia foi feita partindo da abordagem sobre o movimento antivacina como questão norteadora, a fim de que desenvolva neste grupo social um olhar crítico perante os fatos que envolvem a pandemia, ocasionada pelo Sars-CoV-2, bem como a produção vacinal para a mesma moléstia. Desta forma, acreditamos que tal olhar crítico possibilitará ao grupo discente o desenvolvimento da alfabetização científica, permitindo que saibam discernir as informações e emitir opiniões fundamentadas.

Sendo assim, o objetivo geral é avaliar o potencial de alfabetização científica de uma sequência didática com enfoque CTS - Ciência, Tecnologia e Sociedade aplicada aos alunos ingressantes e concluintes do ensino médio de uma escola pública em maio de 2021, trazendo como tema o atual cenário vivenciado nas aulas remotas com enfoque CTS e Esse enfoque é abordado nos currículos da área de ciências desde a década de sessenta, sempre tendo como objetivo principal o preparo do aluno para que ele saiba exercer a cidadania e se posicionar em relação ao seu contexto científico, político e social (AZEVEDO, 2013). 
Cabe ao professor, apesar das dificuldades enfrentadas com aulas remotas, oferecer aos alunos temas que possibilitem o enfoque CTS e a formação crítica do aluno. No caso desse artigo foram abordados temas atuais nas aulas de Biologia, proporcionando conhecimento para formação individual e coletiva do cidadão.

\section{DESENVOLVIMENTO}

\section{Um pouco de história}

Os coronavírus humanos (HCoVs) foram identificados pela primeira vez em meados da década de 1960, são conhecidos por causar infecções entéricas e/ou respiratórias. Nas últimas duas décadas, três HCoVs surgiram, incluindo a síndrome respiratória aguda grave coronavírus 2 (SARS CoV2), que deu início à pandemia atual. O SARS-CoV-2 provoca uma doença respiratória que se apresenta como uma doença respiratória superior leve, podendo resultar em síndrome do desconforto respiratório agudo, falência de múltiplos órgãos e pode ser fatal, especialmente quando comorbidades subjacentes estão presentes (ALMEIDA et al., 2020; XAVIER et al., 2020).

Se voltarmos no tempo vimos situação parecida, em meados de 1904, chegava a 1.800 o número de internações devido à varíola no Hospital São Sebastião. Mesmo assim, as camadas populares rejeitavam a vacina, que consistia no líquido de pústulas de vacas doentes. Afinal, era esquisita a ideia de ser inoculado com esse líquido. $E$ ainda corria o boato de que quem se vacinava ficava com feições bovinas. A esse movimento foi dado o nome de "A revolta das vacinas" (FIOCRUZ, 2005).

Apesar de tal fato ter ocorrido há mais de 100 anos, temos vivenciado o mesmo movimento popular em tempos de pandemia durante os anos de 2020 e 2021, chamado de negacionismo da vacina. Se trata de informações compartilhadas de forma globalizada com reportagens falsas ou desviadas em redes sociais, movimento conhecido como fake news. São informações falsas, de fácil propagação em meio à população, o assunto desperta a curiosidade dos estu- 
dantes e cabe ao docente trazer informações corretas em sala de aula para auxiliar no combate às fakes news.

São vários aspectos que podem ser comparados com a Revolta da Vacina e o movimento atual, na época de 1904 algumas pessoas achavam que se tomassem a vacina ficariam com feições bovinas, enquanto no momento atual, circula a desinformação propagada pelos apreciadores do movimento antivacina, com comentários como, "se tomar a vacina pode virar jacaré". Tais ideias demonstram como a ignorância e a falta de conhecimento sobre o método científico podem induzir ideias absurdas serem vistas como verdades.

Vale contextualizar que a imunização ativa é a conhecida vacinação, no qual os linfócitos desenvolvem memória para antígenos de patógenos, então o indivíduo em contato com o organismo vivo no ambiente terá uma resposta rápida e eficaz imune ao organismo. Dessa forma, a pessoa se protege e auxilia toda a sociedade, desde as pessoas de seu convívio até as de outros países, de forma indireta, quando não transmite o vírus.

Para Sato (2018, p.7), a queda das coberturas vacinais no território brasileiro parece estar atrelada não pela "avaliação racional das evidências, mas sim, na sensação de incertezas e ambiguidades". Demonstrando assim o quanto uma abordagem CTS permitirá o desenvolvimento de um raciocínio crítico adquirido por meio de uma alfabetização científica de qualidade, sabendo o educando então discernir sobre o que é ou não verdade.

Na segunda metade do século XX, o conhecimento científico sobre os processos biológicos se aprofundou rapidamente, o que melhorou a compreensão da ciência sobre uma série de fenômenos desenvolvidos de novas tecnologias e os avanços tecnológicos proporcionaram na área da saúde a biotecnologia, reduzindo os custos de diagnósticos ao proporcionar a realização de testes diversos com uma única amostra de sangue, o que permitiu o desenvolvimento de vacinas em larga escala em pouco tempo.

A história das vacinas teve seus altos e baixos ao longo da história no Brasil, "As vacinas visam à produção de imunidade a doenças pelo estímulo à produção de anticorpos específicos" (WHO, 2021). As contestações das vacinas 
existem desde que as primeiras campanhas foram feitas a partir de argumentos que evocam a ética, a efetividade e a segurança dessas substâncias.

A história se repete de forma similar no ano de 2021, quando os avanços tecnológicos continuam favorecendo a biotecnologia, as informações são de livre acesso às populações de forma rápida. Mas, ao mesmo tempo, fazem com que uma parte da população tenha dúvidas quanto às informações que chegam em seus lares, conhecido popularmente como Fakes News (notícias falsas), que acarretou um movimento antivacina. Neste cenário, os cientistas incansavelmente têm-se mostrado firmes quanto à questão da saúde e bem-estar social e em defesa às vacinas. É indispensável permitir o acesso à informação à sociedade, incentivar a vacinação e promover o bem-estar social. A decisão de se vacinar é além de um direito individual, uma questão de saúde pública e esforço conjunto, que previne óbitos e sequelas. Vacinas foram criadas para a preservação da vida e propiciar que um dos maiores avanços da humanidade na saúde se torne um vilão da sociedade é reprovável e inqualificável.

Tanto o Brasil quanto o mundo têm enfrentado o surto do vírus SARS-CoV-2, que ficou conhecido como Covid-19. Causador de complicações respiratórias e até mesmo síndromes respiratórias agudas, um triste marco do século XXI, com mais de quatrocentos mil brasileiros mortos em todo o país além de mais de três milhões de mortes no mundo todo e com isso, existem cientistas de todos os países engajados em pesquisa para a fabricação de uma nova vacina desde o ano de 2020. "Porém, temos poucas empresas, segundo reportagem da revista Nature Biotechnology de setembro de 2005, apenas cinco empresas produziam vacinas em 2005, comparadas com as mais de 25 que o faziam em 1967" (FORDE, 2005). Dessas cinco empresas, atualmente temos duas no Brasil capazes de produzir vacinas: Bio-Manguinhos, da Fiocruz, e o Instituto Butantan.

De modo geral, "compreende-se por biotecnologia a utilização de métodos biológicos de manipulação de seres vivos na produção, conservação e desenvolvimentos de recursos naturais, com a finalidade de aumentar o desempenho dos seres vivos" (TARACHI, 2016). As indústrias de permitiram a criação de vacinas mais eficazes, com menos efeitos colaterais sendo consideradas seguras. 
As primeiras gerações de vacinas são oriundas de vírus ou bactérias inativados (mortos) ou atenuados. Já as vacinas de segunda geração utilizam a tecnologia do DNA recombinante. A terceira e mais avançada geração de vacinas vem despertando maior interesse da indústria farmacêutica, são as chamadas vacinas gênicas ou vacinas de DNA.

Compreende-se que "o objetivo da vacinação é fazer a apresentação desses microrganismos ao corpo, que irá gerar memória imunológica, protegendo o organismo contra uma nova exposição a esses patógenos" (FARHAT, 2008). Isso gera uma resposta imune mais rápida, específica e eficaz contra determinado patógeno chamado de resposta de memória imunológica.

Cabe pontuar que, a nosso ver, tratar sobre temas relacionados à área da saúde, em meio a uma pandemia, com disputa de narrativas e excesso de informações falsas é, sem dúvidas, um desafio e um risco à saúde, individual e coletiva, em uma sociedade que não possui o devido preparo para atuar e realizar a leitura crítica das informações recebidas.

De acordo com Zanotello e Almeida (2013), os textos de divulgação indicados como leitura introdutória de alguns temas estabelecidos, podem contribuir com a amplificação dos objetivos do ensino das Ciências.

Para Santos e Mortimer, (2002)

O estudo de temas, ... permite a introdução de problemas sociais a serem discutidos pelos alunos, propiciando o desenvolvimento da capacidade de tomada de decisão. Para isso, a abordagem dos temas é feita por meio da introdução de problemas, cujas possíveis soluções são propostas em sala de aula após a discussão de diversas alternativas, surgidas a partir do estudo do conteúdo científico, de suas aplicações tecnológicas e consequências sociais.

Como declarado por Magalhães et al. (2017), existe uma necessidade de se promover alfabetização cientifica, que prepare os cidadãos para a tomada de decisões que envolvam aspetos da ciência e tecnologia.

A alfabetização científica pode desenvolver no individuo a capacidade de argumentar, contra-argumentar, pesquisar, executar, construir, saber pensar e exercer cidadania (MAGALHÃES et al., 2017), compreender melhor as mani- 
festações do universo, fazer correções em ensinamentos que são apresentados distorcidos (CHASSOT, 2003).

A abordagem CTS - Ciência Tecnologia e Sociedade, fomenta a alfabetização científica e tecnológica formando indivíduos conhecedores de sua realidade social, reflexivos e críticos. Esta proposta, visa o protagonismo juvenil, o aluno como participante ativo no processo de ensino aprendizagem.

A educação cidadã tem como meta a Co-construção sem meu do saber e da cidadania. Estimula o aprender e pensar, a protestar, a negociar, a conviver, a argumentar, a desconfiar dos nossos preconceitos, a ouvir os outros, a protelar juízos, a apreciar o valor da democracia, a empenhar-nos na construção coletiva de um mundo melhor. Compreende a educação em, pela e para a cidadania. (SANTOS, 2010, p.87).

Neste contexto não cabe ao docente a mera transmissão de conhecimentos, mas sim, sua ação como mediador no processo de ensino- aprendizagem, incentivando à busca de novos saberes, o desenvolvimento da leitura atenta nos diversos formatos de textos, diante do pluralismo de ideias no mundo que nos cerca, contribuindo para a formação do aluno como cidadão do mundo, e transformador de sua própria realidade, capaz de agir em sua comunidade.

Despertar no aluno a curiosidade pelo mundo que o cerca, como sujeito ativo e transformador, segundo Freire (2020, p. 74-75):

O mundo não é. O mundo está sendo. Como subjetividade curiosa, inteligente, interferidora na objetividade com que dialeticamente me relaciono, meu papel no mundo não é só o de quem constata o que ocorre, mas também o de quem intervém como sujeito de ocorrências. Não sou apenas objeto da história, mas seu sujeito igualmente. No mundo da história, da cultura, da política, constato não para me adaptar, mas para mudar.

Nesta concepção, a proposta de sequência didática apresentada neste artigo foi aplicada em duas unidades de Ensino Técnico Estadual, (aqui denominadas Unidades 1 e 2) situadas na Zona Leste do município de São Paulo. Utilizou-se uma sequência didática com abordagem CTS, adaptadas a cada público-alvo, em duas realidades distintas. Como sequência didática (SD) entende-se, segundo Zabala (1998), que é um conjunto de atividades ordenadas, estruturadas e articuladas para a realização de certos objetivos educacionais, com princípio e fim determinados, tanto pelo docente quanto pelo estudante. Este tipo 
de recurso didático, ajuda o docente a problematizar conhecimentos científicos em poucas aulas, nele o aluno estudará e discutirá um determinado tema de forma aprofundada. O uso da SD, como um novo mecanismo pedagógico, propicia a organização curricular e permite a utilização de situações reais do cotidiano, pois parte da problematização, levando o estudante a observar e confrontar o seu conhecimento prévio como as novas informações que lhe são apresentadas (SILVA; BEJARANO, 2013; MAROQUIO et al., 2015; BASTOS et al. 2017).

As aulas foram ministradas no formato remoto, devido ao isolamento social durante o período pandêmico. A sequência didática foi realizada em duas turmas do primeiro ano do Ensino Médio da Unidade 1, totalizando 79 alunos, denominados ingressantes e em três turmas do terceiro ano do Ensino Médio na Unidade 2, totalizando 111 alunos, denominados concluintes e ambas as unidades a sequência didática teve as seguintes atividades: uma primeira etapa com desenvolvimento de conteúdo teórico e a segunda etapa com produção de texto crítico.

Na primeira etapa foi realizado uma exposição dialógica com recurso visual sobre o tema Vírus e Doenças associadas, conteúdo previsto em Plano de Curso, e a partir da temática contextualizada com a realidade mundial foi abordado sobre a vacinação, processo de pesquisa e produção, ação das vacinas no corpo humano e tipos de vacinas. Esta apresentação teórica com interação dos alunos ocorreu via Ambiente Virtual de Aprendizagem utilizado pela instituição durante o ensino remoto. As atividades foram desenvolvidas em oito aulas na primeira unidade e quatro aulas de aproximadamente cinquenta minutos, na segunda unidade.

Na unidade 1, os alunos participaram de uma aula introdutória, abordando as principais pandemias e epidemias que assolaram a humanidade, as formas de tratamento e prevenção destas doenças, em seus contextos históricos, sociais e tecnológicos. A partir dos diversos questionamentos indicados pelos discentes, foram sugeridas a análise de três vídeos de divulgação científica: "História das vacinas", do canal Nerdologia; "Existe perigo na vacina?"2 do canal, Nerdologia;

1 Disponível em: <https://youtu.be/ENttrlq3zmg> Acesso em: 08 set. 2021.

2 Disponível em: <https://youtu.be/MilZISNAu0E> Acesso em: 08 set. 2021. 
"Revolta da vacina", do canal Vídeo Saúde da Fiocruz

Os alunos tiveram uma semana para assistir aos vídeos indicados, refletir sobre as informações divulgadas e realizar o registro de seus questionamentos ou anotar as informações que julgarem pertinentes, dos temas abordados.

Na unidade 2, os discentes foram convidados a assistir ao vídeo: "Histórias do Brasil - A Revolta da Vacina"2 da TV Senado, e após análise dele, fazer anotações que julgassem importantes sobre o contexto apresentado, ligando o tema abordado no vídeo com o atual cenário de saúde pública no mundo.

Na segunda etapa, ocorreu a produção do texto crítico, o qual os alunos foram instigados a realizar, utilizando o movimento antivacina como questão norteadora. Na Unidade 1, a entrega do texto ocorreu por formulário e na Unidade 2, o texto foi compartilhado no mural virtual da ferramenta Padlet.

$\mathrm{Na}$ análise dos dados utilizou-se a pesquisa qualitativa, de natureza interpretativa. Foi realizada análise qualitativa do gênero textual produzido pelo público-alvo, avaliando a coesão das informações, o relacionamento de conceitos, a criticidade da escrita e a fundamentação teórica de suas produções. Para cada grupo distinto, as autoras adaptaram a Sequência Didática utilizada, uma vez que temos duas situações distintas, na primeira unidade os alunos ingressantes, que serão estimulados a desenvolver o olhar científico e crítico ao longo de sua formação. Enquanto na segunda unidade, temos alunos concluintes, que já trazem na sua bagagem ao longo dos três anos do Ensino Médio, o desenvolvimento de competências e habilidades que envolvem um olhar científico, tecnológico e crítico às ações da sociedade.

\section{RESULTADOS E DISCUSSÃO}

Após conhecer as características dos vírus e das principais doenças virais, os alunos da unidade 1, mostraram-se surpresos com as vinte oito epidemias e pandemias que ocorreram ao longo da história, e vários questionamentos foram realizados pelos alunos nas aulas síncronas ou por meio de perguntas realizadas

1 Disponível em: <https://youtu.be/amwFWGMJhUw> Acesso em: 08 set. 2021.

2 Disponível em: <https://youtu.be/6i6v9f_aWjg> Acesso em: 08 set. 2021. 
no chat das aulas. Após a indicação dos vídeos, novos questionamentos foram levantados, pelos alunos, indicando uma participação ativa e crítica em meio a divulgação cientifica apresentadas nos vídeos.

Baseado nestas questões foram apresentadas, no powerpoint, dados divulgados nos sites do ministério da saúde, revista pesquisa Fapesp, guia do estudante, sociedade Brasileira de imunizações, Instituo Butantan e Fiocruz, dados correspondentes as questões indicadas pelos alunos. Motivando assim a procura de informações em canais de divulgação científica, confiáveis e atualizados.

Os assuntos discutidos na interação virtual foram: ação do sistema imunológico contra as doenças e alergias, produção, diferentes tipos e formas de administrar as vacinas, Os papéis desempenhados pela Agência Nacional de Vigilância Sanitária (Anvisa), Sistema Único de Saúde (SUS), Sistema de Vigilância de Eventos Adversos Pós-vacinação (EAPV), Programa Nacional de Imunização (PNI), Ingrediente Farmacêutico Ativo (IFA), Diferença entre soro terapêutico e vacina, variantes de um vírus, e Imunidade de rebanho.

Como proposta de encerramento do tema, os alunos foram convidados a assistir dois vídeos: "O que é o movimento antivacina?" com Paulo Sérgio e "O mito e o perigo do movimento antivacina"2 com Natália Pasternak. Após a análise dos vídeos responderam a esta questão: Escolha uma informação equivocada (Fake News), em relação à vacinação da Covid-19, que circula nas redes sociais ou entre pessoas do seu convívio. Copie essa Fake News, indique o que chamou a sua atenção nesta informação e explique, com base em conhecimentos científicos, como combater essa notícia falsa. As produções textuais foram postadas via formulário indicando uma postura crítica, vários alunos relataram suas indignações em relação às diversas informações propagadas nas redes sociais ou na comunidade onde residem.

Alguns alunos mencionaram as tentativas, e como, convenceram familiares e vizinhos, quando explicaram a importância e a relação das vacinas com as doenças infecciosas provocadas por vírus e bactérias. Este fato caracteriza o impacto de fomentar estratégias de ensino com foco CTS.

$1 \quad$ Disponível em: <https://youtu.be/vmz-pqsev88> Acesso em: 08 set. 2021.

2 Disponível em: <https://youtu.be/SmMt2pXgnto> Acesso em: 08 set. 2021. 
$\mathrm{Na}$ Unidade 2, foi possível perceber que os discentes apresentam uma visão holística dos fatos, uma vez que conseguem exercer comparações críticas do momento denominado "Revolta das Vacinas" para a situação atual que a Saúde Pública brasileira vem enfrentando. Eles conseguem associar ciência, tecnologia, política e educação em suas produções textuais, demonstrando assim a criticidade na análise dos fatos.

Descrevem o quanto houve retrocesso social, devido às Fake News, o quanto a informação está disponível a todos, porém é necessário que haja uma educação pautada na ciência para que falsas notícias não ganhem tamanha repercussão na mídia e redes sociais. Demonstram em suas escritas a necessidade de o conhecimento científico ser divulgado de forma fidedigna, acreditam que a situação de 1904 era justificável porque não havia conhecimento sobre as vacinas e seus resultados, porém hoje, em pleno século XXI, julgam inaceitável o movimento antivacina, pois acreditam ser problema de contextualização política. Demonstram claramente a construção de um vocabulário pautado em informações científicas, tecnológicas, políticas e educacionais, exercendo claramente a cidadania crítica.

Considerando a escola como lócus de formação para a cidadania, compreende-se que o ensino de Ciências assume papel fundamental, pois favorece o entendimento dos avanços, benefícios, implicações e consequências do desenvolvimento científico-tecnológico, tanto para o meio ambiente quanto para as relações sociais. (CHASSOT, 2018)

Em ambos os estudos, percebeu-se que os discentes produziram textos fundamentados na ciência, com um olhar crítico condizente ao seu grau de formação. Desta forma, portanto, desenvolvendo cada vez mais seu pensamento crítico e sua formação para o exercício da cidadania, contribuindo assim com uma participação mais consciente de cada um deles frente às Fake News.

\section{CONCLUSÃo}

A escolha desta temática se deu pelas indagações dos alunos diante do pluralismo de ideias divulgados nas redes sociais, nos veículos de comunicação e entre amigos, como tema global que envolve conflitos de interesse, científico, social e político. 
O desafio da docência neste trabalho, com abordagem CTS, foi o de incentivar nos alunos ingressantes a curiosidade pelos temas relacionados ao cotidiano, a leitura atenta das informações e o posicionamento crítico baseado nas descobertas da ciência e da tecnologia produzidas por humanos. Essas ações têm como intuito desenvolver com os discentes competências como: compreender fenômenos, construir argumentos, elaborar propostas, domínio da linguagem; e habilidades como: clareza na expressão oral e escrita, criatividade na resolução de problemas, pertinência das informações; além de atitudes e valores como: autonomia, diálogo, interlocução e a capacidade de se responsabilizar pela utilização e divulgação de informações. Nesse sentido, percebemos, ao observar o grupo de alunos concluintes, que eles atingiram as habilidades necessárias para desempenhar um olhar crítico sobre as questões apresentadas, pautados em dados científicos, sabendo, desta forma, discernir as informações verdadeiras das falsas, e emitindo opiniões de maneira holística, exercendo, portanto, o papel de cidadão crítico.

Concluímos que a sequência didática aplicada subsidiou a formação de um cidadão que saiba se pronunciar sobre os temas atuais, em diferentes contextos, baseados no conhecimento científico e tecnológico em construção e não apenas na mera repetição de conhecimentos imutáveis, absolutos. Essa abordagem auxilia, assim, na busca por informações relevantes em fontes confiáveis de divulgação científica, com referências fidedignas, proporcionando aos alunos um lugar de fala na participação social e na tomada de decisões.

Ponderamos que um ensino humanístico possibilita a formação do cidadão com consciência planetária, e que, a escola favorece o desenvolvimento de competências, habilidade, valores e atitudes, nos educandos, contribuindo com a formação de indivíduos conscientes do seu papel no mundo e das consequências de suas ações.

\section{REFERÊNCIAS}

AZEVEDO, R. O. M. et al. Questões sociocientíficas com enfoque CTS na formação de professores de Ciências: perspectiva de complementaridade. Amazônia: Revista de Educação em Ciências e Matemáticas, v. 9, n. 18, p. 84-98, 2013. Acesso em: 29 jul.2021 
ALMEIDA, J. O.; OLIVEIRA, V. R. T.; AVELAR, J. L. S.; MOITA, B. S.; LIMA, L. M. COVID-19: Fisiopatologia e Alvos para Intervenção Terapêutica. Rev. Virtual Quim., vol.12, n.6, Rio de Janeiro: 2020. Disponível em: http://static.sites.sbq. org.br/rvq.sbq.org.br/pdf/RVq170920-a4.pdf. Acesso em 20 de jun. 2021

BASTOS, M. R., SILVA-PIRES, F. E. S., FREITAS, C. A. V., TRAJANO, V. S. (2017). A utilização de sequências didáticas em biologia: revisão de artigos publicados de 2000 a 2016. Anais do XI Encontro Nacional de Pesquisa em Educação em Ciências, p. 1-11, 2017.

BRASIL. MEC. Portaria $n^{\circ}$ 544, de 16 de junho de 2020. Dispõe sobre a substituição das aulas presenciais por aulas em meios digitais, enquanto durar a situação de pandemia do novo coronavírus - Covid-19, e revoga as Portarias MEC $n^{\circ}$ 343 , de 17 de março de 2020, n 345, de 19 de março de 2020, e $n^{\circ} 473$, de 12 de maio de 2020. Disponível em: https://www.in.gov.br/en/web/dou/-/portaria-n-544-de-16-de-junho-de-2020-261924872. Acesso em: 30 jun. 2021.

CARVALHEIRO, J. da R. Epidemias em escala mundial e no Brasil. Estudos Avançados, v. 22, p. 7-17, 2008

CHASSOT, A. Alfabetização científica e cidadania. In. CHASSOT, Attico. Alfabetização científica: questões e desafios para a educação. 8. ed. ljuí: Unijuí, 2018, p. 31-52.

CHASSOT, A. Alfabetização científica: uma possibilidade para a inclusão social. Revista brasileira de educação, p. 89-100, 2003.

CREAGER, A. N. H. A vida de um vírus: o vírus do mosaico do tabaco como modelo experimental, 1930-1965. University of Chicago Press, 2002.

CARVALHO, A. P. Sociedade Brasileira de Pediatria - Departamento Científico de Infectologia, março de 2020. Disponível em: . Acesso em: 28 de julho de 2021.

FARHAT, C.; WECKX, L.; CARVALHO, L.; SUCCI. R. Imunizações, fundamentos e prática. 5. ed. São Paulo: Atheneu, 2008.

FIOCRUZ Fundação Oswaldo Cruz. Portal Fiocruz. A Revolta da Vacina. Disponível em: https://portal.fiocruz.br/noticia/revolta-da-vacina. Disponível em: Acesso em: 25 jun. 2021.

FORDE, G. "Rapid response vaccines - does DNA offers asolution?". Nature Biotechnology, v. 23, n. 9, set. 2005. 
FREIRE, P. Pedagogia da autonomia: Saberes necessários à prática educativa. 65. ed. São Paulo: Paz e Terra, 2020. 143 p.

JARED, C. Contribuição ao estudo da Microscopia Eletrônica no Instituto Butantan. Cadernos de História da Ciência, v. 11, n. 2, 2015.

MAGALHÃES, C; DA S, Evanilda; GONÇALVES, C. . A interface entre alfabetização científica e divulgação científica. Revista Areté, Revista Amazônica de Ensino de Ciências, v. 5, n. 9, p. 14-28, 2017.

MAROQUIO, V. S.; PAIVA, M. A. V.; FONSECA, C. O. Sequências didáticas como recurso pedagógico na formação continuada de professores. In: ENCONTRO CAPIXABA DE EDUCAÇÃO MATEMÁTICA, 10., 2015, Vitória: SBEM, 2015

SANTOS, M. E. do N. V. M. A dimensão CTS do ensino das ciências: fundamentos, contextos e desafios. In: MACIEL, Maria Delourdes; AMARAL, Carmem Lúcia Costa; GUAZZELLI, lara Regina Bocchese. Ciência, Tecnologia \& Sociedade: pesquisa e ensino. São Paulo: Terracota, 2010. p.71- 92

SANTOS, W. L. P. dos; MORTIMER, E. F. Uma análise de pressupostos teóricos da abordagem C-T-S (Ciência - Tecnologia - Sociedade) no contexto da educação brasileira. ENSAIO Pesquisa em Educação em Ciências. V. 2, n. 2, p.1-23, dez., 2002.

SATO, A. P. S.. Qual a importância da hesitação vacinal na queda das coberturas vacinais no Brasil? Revista de Saúde Pública, v. 52, n.96, 2018. Disponível em: https://www.scielo.br/j/rsp/a/CS5YRcMc3z4Cq4QtSBDLXXG/?lang=pt\&forma$\mathrm{t}=$ pdf. Acesso em: 20 jun.2021.

SILVA, E.L.; BEJARANO, N.R.R. In. As tendências das sequências didáticas de ensino desenvolvidas por professores em formação nas disciplinas de estágio supervisionado das Universidades Federal de Sergipe e Federal da Bahia. IX Congreso Internacional sobre Investigación en Didáctica de las Ciencias, $\mathrm{n}^{\circ}$ extra, p. 942- 1948, Girona, 2013.

TARICHI, A. Modelos de referência para desenvolvimento de novos produtos para pesquisas futuras no setor de biotecnologia. Revista UNIFEV: Ciência \& Tecnologia, Votuporanga, v.1, n.1, 2016, p.146-157. Disponível em: https://repositorio. uniceub.br/jspui/Handle/ 235/11699. Acesso em: 27de jun.2021. 
WHO-World Health Organization. Disponível em: http://www.who.int/topics/ Vaccines/en/. Acesso em: 27 de junho de 2021.

XAVIER, A. R., SILVA, J. S., ALMEIDA, J. P. C., CONCEIÇÃO, J. F. F., LACERDA, G. S., KANAAN, S. COVID-19: manifestações clínicas e laboratoriais na infecção pelo novo coronavírus. Jornal Brasileiro de Patologia e Medicina Laboratorial, v. 56, 2020. Disponível em: https://www.scielo.br/j/jbpml/a/PrqSm9T8CVkPdk4m5Gg4wKb/abstract/?lang=pt. Acesso em 20 de Jun. 2021

ZABALA, A. A Prática Educativa: como ensinar. Porto Alegre: Artmed, 1998.

ZANOTELLO, M.; ALMEIDA, M. J. P. M. de. Leitura de um texto de divulgação científica em uma disciplina de física básica na educação superior. Ensaio Pesquisa em Educação em Ciências (Belo Horizonte), v. 15, p. 113-130, 2013. 
doi $10.48209 / 978-65-89949-11-8$

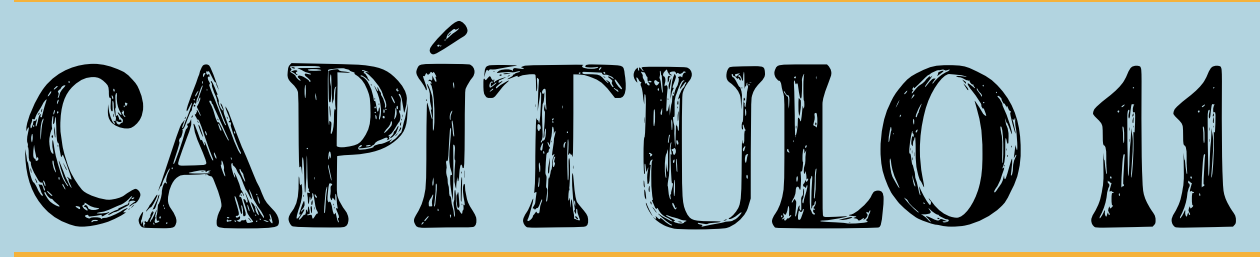

INTERVENÇÃO PEDAGÓGICA EM ESPAÇO NÃO-FORMAL DE EDUCAÇÃO: TRILHA INTERPRETATIVA VIRTUAL COM TEMA RECICLAGEM

Larissa Rodrigues Pereira Ana Flavia Zorzi Mayra da Silva Cutruneo Ceschini 


\section{INTRODUÇÃo}

Os resíduos sólidos se configuram como um grande problema ambiental, tanto por seu descarte incorreto quanto pela sua destinação errônea. Dentre muitas possibilidades para sanar essa questão, uma alternativa para diminuir esse tipo de impacto é a coleta seletiva e a reciclagem, a partir de uma abordagem crítico-transformadora. A Educação Ambiental em sua vertente transformadora destaca dimensões historicamente esquecidas no fazer educativo para promover o entendimento da natureza e para denunciar dicotomias sociais, sendo promotora de ações que promovam a superação das relações socioambientais vigentes (LOUREIRO, 2004).

Quando se refere à Educação Ambiental, do ponto de vista integrador, Minc (2005, p.71) afirma que "as escolas devem funcionar como polos irradiadores da consciência ecológica, envolvendo as famílias e a comunidade". A mesma concepção é citada por Krasilchik (2005), quando reafirma que,

A educação ambiental deverá ter um enfoque global e integrado, não podendo ser reduzida a uma disciplina escolar. Deverá ser responsabilidade de toda a escola e permear todo o currículo escolar, visando, em última instância, que a comunidade se estruture e se organize para o desenvolvimento de pesquisas permitindo que, com recursos próprios e tecnologia adequada, sejam resolvidos os problemas prioritários. (KRASILCHIK, 2005, p. 192).

Nessa perspectiva, trabalhar com Educação Ambiental não significa apenas ensinar a reciclar, mas sim possibilitar que os estudantes compreendam a importância desta ação para o meio ambiente e para as pessoas que dele dependem. Essas atividades educativas podem e devem ocorrer dentro e fora da escola, de forma que o educando se integre com a temática em diferentes ambientes, por meio de metodologias participativas. Para tanto, segundo Loureiro (2004, p. 72-73), “deve, metodologicamente, ser realizada pela articulação dos espaços formais e não-formais de educação; pela aproximação da escola à comunidade em que se insere e atende; pelo planejamento integrado de atividades curriculares e extracurriculares".

Além disso, de acordo com Wojciechowski (2006), o saber ambiental deve ir se construindo desde a infância, respeitando os níveis de maturidade 
dos educandos, partindo da experiência concreta com o meio físico e social, procurando soluções para os problemas socioambientais locais. Para isso, há a necessidade de se criar, na escola, um contexto dialógico de saberes e conhecimentos, que problematize os paradigmas estabelecidos, objetivando a construção de uma nova racionalidade socioambiental, que não se submeta simplesmente aos desígnios de um mundo capitalista. Ou seja, é importante que criemos espaços de diálogo entre diferentes sujeitos e realidades, provocando a construção crítica de conhecimentos acerca das questões socioambientais, visando a ruptura gradual com os padrões societários dominantes.

Diante disto, acreditamos que é importante trabalhar a temática reciclagem no ambiente escolar, o qual é o principal meio em que os sujeitos estão inseridos para mediar um pensamento crítico e reflexivo de suas ações, com responsabilidade social e coletiva. O incentivo à reciclagem no espaço educacional parte de práticas que podem ser incluídas pelas equipes gestora e pedagógica no âmbito escolar e, através disso, é possível que resulte na melhoria dos hábitos dos alunos sobre o descarte correto dos resíduos, visto que o desenvolvimento da consciência ecológica é cada vez mais pertinente e importante no mundo em que vivemos, sendo desenvolvida a partir do processo educativo "permanente, cotidiano e coletivo pelo qual agimos e refletimos, transformando a realidade de vida" (LOUREIRO, 2004, p. 81).

A partir desse ponto teórico-conceitual justificamos a necessidade da realização deste trabalho, pois conforme os autores supracitados é importante promover a sensibilização dos estudantes a partir de problemas ambientais vivenciados de forma local, sendo a questão da reciclagem um ponto de abordagem tangível a partir de diferentes realidades socioambientais, pois, independente da classe social que ocupamos, descartamos diariamente muitos resíduos, que necessitam ser gerenciados, sendo eles possíveis subsídios práticos para a construção e a consolidação de conhecimentos em Educação Ambiental.

Além disso, práticas de ensino não-formais são importantes aliadas para ações de Educação Ambiental, pois promovem o processo de ensinoaprendizagem sem seguir vários requisitos formais e podem ser realizadas em qualquer ambiente, desde que apresentem uma dinâmica diferente de aulas expositivas, não priorizem a memorização e utilizem ferramentas didáticas 
diversificadas e atrativas (D'ÁVILA; QUADRA, 2016).

Nesse sentido, este trabalho nasce em meio ao cenário pandêmico vivenciado desde março de dois mil e vinte, que nos colocou em isolamento social e em atividades de ensino no formato emergencial remoto, dessa forma fomos desafiados a apresentar o espaço educativo, Trilha Interpretativa Campus Verde, que o campus São Gabriel da Universidade Federal do Pampa (UNIPAMPA) possui, de forma virtual. Para isso, foi desenvolvido um site dentro do Componente Curricular de Estágio em Educação Não-Formal, do Curso de Licenciatura em Ciências Biológicas da referida Universidade. Foi uma atividade colaborativa entre universitários dos cursos de Bacharelado e Licenciatura, desenvolvida no segundo semestre letivo de 2020 , dentro das atividades de ensino remoto emergenciais. Tal atividade teve como o objetivo proporcionar ao público uma vivência virtual na Trilha Interpretativa Campus Verde, com relação ao descarte correto de resíduos e promover a conscientização ambiental.

\section{METODOLOGIA}

No desenvolvimento da atividade o intuito era oportunizar e despertar o olhar e interesse dos alunos para a temática reciclagem. O planejamento da atividade contemplou aspectos fundamentais para o seu desenvolvimento, como, por exemplo, o de como a atividade iria ser realizada perante o momento da pandemia causada pela COVID-19. Nesse sentido, foi pensado em construir a Trilha Virtual a partir dos pontos já existentes na Trilha Campus Verde da UNIPAMPA, para assim, não deixar de desfrutar do espaço da Trilha da Universidade e promover uma integração da comunidade com ela.

A trilha "Campus Verde" tem, aproximadamente, $1 \mathrm{Km}$ de comprimento e percorre 10 pontos interpretativos, sendo eles: 1 - Compostagem; 2 - Botânica Sensorial; 3 - Agrofloresta; 4 - Plantas Alimentícias Não Convencionais (PANC); 5 - Integração; 6 - Zoologia (Peçonhentos); 7 - Paleontologia; 8 - Jardim das Exatas; 9 - Hidrologia; 10 - Meliponário. Para o desenvolvimento da atividade em cada ponto foi aliado à sua temática a reciclagem, contextualizando a mesma com diferentes situações e problemáticas, como por exemplo a ciclagem de materiais importantes para o desenvolvimento vegetal nos pontos 1, 2, 3 e 4; 
a separação correta dos resíduos no ponto 5; a destinação deles no ponto 6; o tempo de decomposição no 7; a quantidade de resíduos produzidos e as possíveis mudanças de atitudes no 8; os impactos na saúde das pessoas e animais nos pontos 9 e 10. Para tanto amparamos os questionamentos em materiais préselecionados, como vídeos e textos, visando a autonomia dos educandos a partir da aproximação com material.

A atividade foi desenvolvida por meio dos pontos interpretativos citados, utilizando como ferramenta um questionário elaborado utilizando o Google Forms, a partir do qual abordamos questões temáticas e objetivas sobre reciclagem, sendo ela pontuadas para o ranqueamento dos estudantes na gincana educativa promovida na atividade, propiciando a construção de conhecimentos e diversão aos participantes. Organizamos as questões por sessões, nas quais incialmente realizamos um levantamento prévio sobre os estudantes, com perguntas de identificação simples, como o seu nome, escolaridade, idade, identificação racial e de gênero. Esses dados foram coletados para facilitar o ranqueamento e para subsidiar futuras adequações na Trilha, visto que ela permanece disponível para ser visitada, seja em uma atividade guiada (com marcação de horário para realização da atividade) ou para visitação livre (mediante acesso direto ao site). Logo após era iniciada as sessões dos pontos interpretativos da Trilha Campus Verde.

A partir da sessão de partida e ao longo da Trilha Interpretativa Virtual trabalhamos com o referencial sobre o reaproveitamento de matérias primas que são descartadas, salientando que reciclar significa diminuir a quantidade de resíduos provenientes dos produtos consumidos pelo homem, entre suas vantagens estão a diminuição da poluição da água, do solo e do ar, redução da acumulação de resíduos, reaproveitamento dos materiais, melhoria da qualidade de vida da população, geração de empregos, formação e desenvolvimento da consciência ecológica, valorização da limpeza pública das cidades, assim como, responsabilidade social e ambiental. Sendo assim, em cada sessão dos 10 pontos foram oportunizadas questões com vídeos didáticos e cards informativos que os alunos deveriam ler e visualizar para responder as questões. Também criamos pontos de ligação entre as sessões, chamados de pontos pista, para 
que os estudantes estabelecessem relações e fossem guiados ao próximo ponto interpretativo.

A Trilha criada por nós foi abrigada em um site ${ }^{1}$, desenvolvido com o propósito de abrigar as trilhas desenvolvidas pelos acadêmicos matriculados no componente curricular de Estágio em Educação Não-Formal, contendo todas as informações sobre a Trilha Interpretativa Campus Verde, descrevendo as atividades de extensão universitária desenvolvidas, permitindo o livre acesso do público às atividades e possibilitando a compreensão da proposta e uma visão geral da Trilha presencial.

Como atividade da componente curricular, além de elaborar a Trilha Virtual, deveríamos aplicá-la, para tanto convidamos uma professora e estudantes de uma turma de $4^{\circ}$ ano de uma escola da rede municipal de ensino de São GabrielRS para visitar o site e a Trilha e, com o nosso auxílio, desenvolver as atividades nela propostas.

\section{RESULTADOS E DISCUSSÃO}

A atividade foi aplicada no mês de abril de dois mil e vinte e um, com uma turma de $4^{\circ}$ Ano do Ensino Fundamental, convidada a visitar nosso espaço não-formal de educação virtual, acompanhados de sua professora. A turma era composta por 36 alunos, mas somente 8 alunos participaram da atividade remota síncrona, que foi realizada pela plataforma Google Meet (Figura 1). Pressupomos, a partir do diálogo prévio e posterior com a professora da turma, que a baixa participação se deu em decorrência da falta de acesso dos estudantes à internet e às plataformas utilizadas para o ensino remoto emergencial durante o período pandêmico, vindo ao encontro das ideias de Barreto e Rocha (2020), que afirmam que mais da metade dos lares brasileiros, sobretudo os das famílias de menor poder aquisitivo, não possuem acesso à internet, fato que afeta ainda mais os estudantes que vivenciam o contexto da Educação Básica em escolas da rede pública, como a escola visitante.

$1 \quad$ O site pode ser encontrado no endereço a seguir: https://www.canva.com/design/DAEZJoylf9M/HLnJ1z_O8si9OgCyOhLvyw/view?website\#2:pr-ticas-de-est-gio-em-educa-o-n-o-formal. 
Além disso, percebemos que alguns educandos tiveram um pouco de dificuldade em acessar a plataforma Google Forms, na qual a Trilha foi desenvolvida, permitindo a reflexão sobre a capacidade de interação e mobilização ativa de conhecimentos durante a pandemia, a partir da Teoria da Aprendizagem Significativa Crítica, proposta por Moreira (2010).

Nessa teoria o autor explicita onze princípios facilitadores para que a aprendizagem aconteça, sendo um deles o "Princípio da não utilização do quadro de giz", que se trata da utilização de diferentes estratégia de ensinoaprendizagem, que implicam na participação ativa dos estudantes e o "Princípio da interação social e do questionamento", que necessita da negociação e compartilhamento constante de significados com o grupo (MOREIRA, 2010), ambos comprometidos pela realidade vivenciada pelos estudantes da escola visitante, que possuem acesso limitado à internet e pouca familiaridade com recursos que tem potencialidade em promover a dialogicidade e os processos interativos para facilitar a aprendizagem significativa e crítica.

Figura 1: Registro da realização da atividade via Google Meet, com os participantes que desejaram realizar o registro fotográfico.

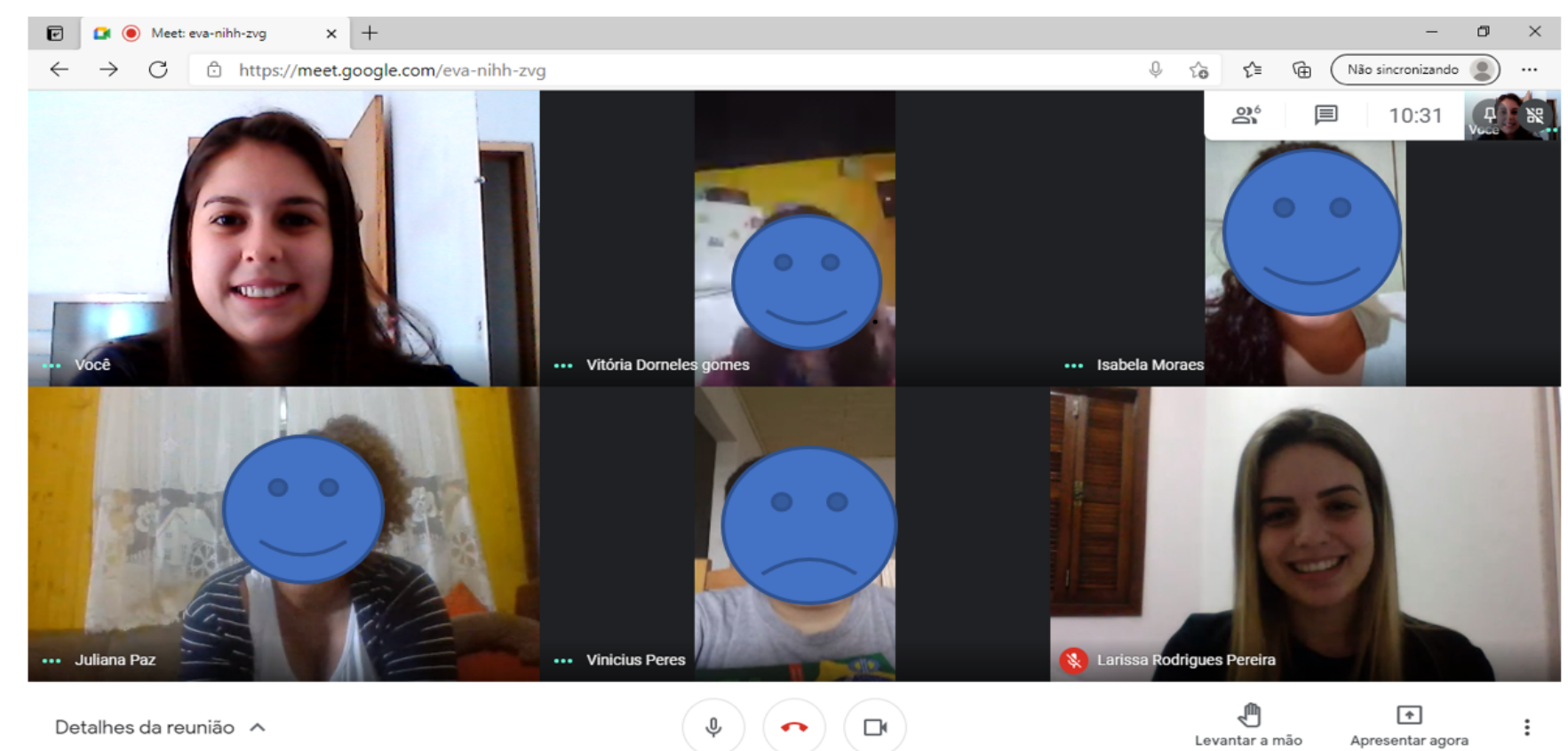

Fonte: Autoras, 2021.

Durante a aplicação das atividades da Trilha Virtual com o tema reciclagem foi possível observar a empolgação e o interesse dos estudantes em construir novos conhecimentos sobre o assunto ali trabalhado. Acreditamos, amparados 
na Teoria da Aprendizagem Significativa Crítica (MOREIRA, 2010), que para a atividade ser significativa e ter relevância para os estudantes, deve contar com a participação ativa, com interesse e disposição em realizar as atividades, fato que foi verificado durante a aplicação, sendo possível inferir que o trabalho foi significativo à construção de conhecimentos em Educação Ambiental.

A pontuação máxima a ser atingida no decorrer da Trilha era 170 pontos, observamos que os alunos ficaram, em média, com a pontuação de 100 pontos (Figura 2). Contudo, cabe salientar que a atividade foi realizada de forma síncrona, com auxílio da plataforma Google Meet, que permitiu a realização de discussões, trocas de significados, negociações, mediações, métodos amparados no "Princípio do abandono da narrativa" pelo professor, apontado por Moreira (2010), que nos permitiu vislumbrar a interação real dos estudantes com a temática trabalhada na Trilha, para além da pontuação aferida nas questões do formulário.

Por meio dos momentos interativos foi possível perceber que eles conseguiram correlacionar muito bem as sessões dos pontos interpretativos e compreender os conceitos relativos à temática, pois a partir do "Princípio da incerteza do conhecimento", o qual nos diz que perguntas são instrumentos de percepção (MOREIRA, 2010), conseguimos captar suas visões de mundo e os constructos que fizeram e/ou aprofundaram durante a atividade, o que acreditamos que para uma turma de $4^{\circ}$ ano seja extremamente positivo.

Figura 2: Resultados obtidos na Trilha Virtual
Mediano
Mediana
Intervalo
$128,89 / 170$ pontos
$130 / 170$ pontos
$90-170$ pontos

\section{Distribuição do total de pontos}

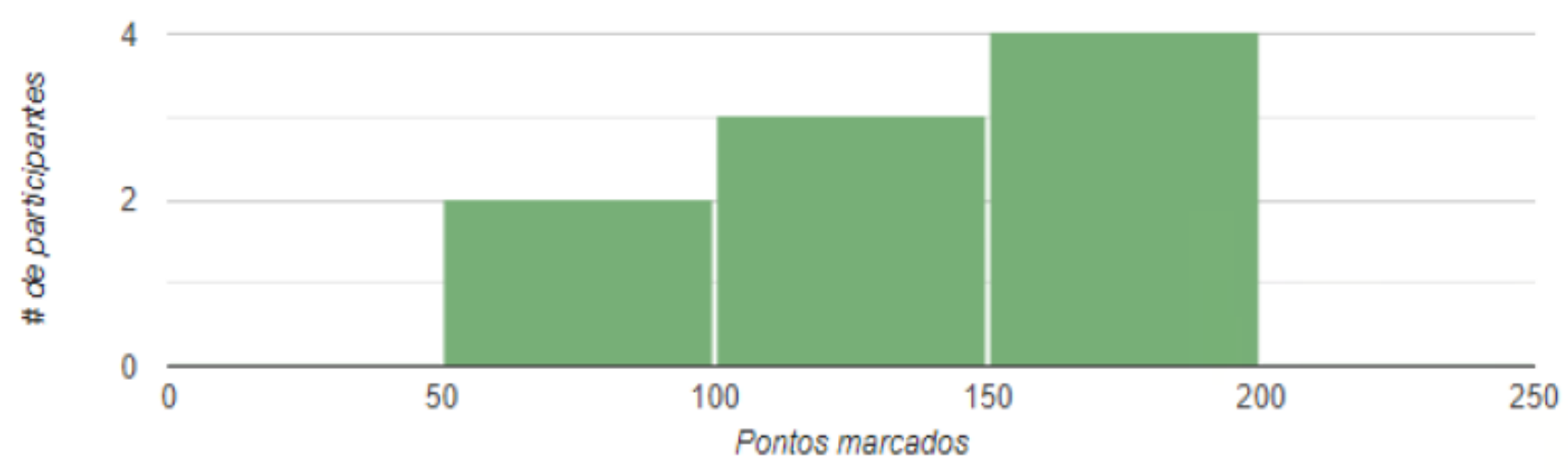

Fonte: Autoras, 2021. 
Nesse sentido, consideramos importante o desenvolvimento de estudos sobre assuntos sociais e coletivos desde os Anos Iniciais, sendo importante incorporar essa temática nos currículos escolares, ainda que como Temas Contemporâneos Transversais (BRASIL, 2018), contribuindo para a formação de cidadãos conscientes e agentes de mudança, pois é nessa faixa etária que os indivíduos estão formando opiniões e obtendo conhecimento sobre os assuntos, sendo campo fértil para propor transformações socioambientais, estabelecendo diferentes patamares de relações na natureza possibilitados por movimentos emancipatórios (LOUREIRO, 2004).

Para tanto, vários autores apontam a importância de abordar a Educação Ambiental nas escolas, a fim de construir conhecimentos que visem à sensibilização e reflexão dos estudantes frente às questões ambientais, tão importantes para os dias atuais. Medeiros e colaboradores (2011) ressaltam a importância de tratar a questão ambiental no ambiente escolar:

A cada dia que passa a questão ambiental tem sido considerada como um fato que precisa ser trabalhado com toda a sociedade e, principalmente, nas escolas, pois as crianças bem-informadas sobre os problemas ambientais vão ser adultos mais preocupados com o meio ambiente, além do que elas vão ser transmissoras dos conhecimentos que obtiveram na escola sobre as questões ambientais em sua casa, família e vizinhas. (MEDEIROS, et al., 2011, p. 02).

Nesse sentido, os estudantes que foram público-alvo da intervenção educativa não-formal são potenciais disseminadores das ideias trabalhadas, pois a metodologia utilizada pautou-se na participação ativa e promoção da cidadania, princípios metodológicos da Educação Ambiental Transformadora, apontados por Loureiro (2004) e da Teoria da Aprendizagem Significativa Crítica, apontados por Moreira (2010).

A oportunidade de desenvolver uma Gincana Ecológica para os educandos foi extremamente desafiadora e diferente das intervenções que vinhamos realizando enquanto práticas pedagógicas em outras componentes curriculares no curso de Licenciatura, incluindo o desafio de elaborar questões para os Anos Iniciais do Ensino Fundamental, que teoricamente deve abranger questões mais simplificadas para propiciar seu entendimento, o que para quem está na graduação exige familiaridade e experiência, pois acabamos nos tornando "reféns" de uma linguagem mais científica e rebuscada, ao contrário do que pretendíamos 
na intervenção, que era aproximar nossa linguagem a da turma e ser menos formal no processo de ensino-aprendizagem. Essa ideia vem ao encontro do que defende Chassot (2007), quando afirma que devemos tornar a linguagem que usamos na academia mais palatável, menos esotérica e mais provida de significados, para facilitar a leitura do mundo por meio do conhecimento científico acessível e menos erudito.

Esse entendimento vem ao encontro do "Princípio do conhecimento como linguagem", no qual Moreira (2010) afirma que a linguagem que conhecemos está ligada as nossas percepções e que quando aprendemos novas linguagens, como a científica, percebemos o mundo de outra forma. Assim, é importante aproximarmos as linguagens, até que o estudante possa explicar o que aprendeu com suas palavras e aplicar esse conhecimento em uma nova situação, tendo obtido assim, uma aprendizagem significativa crítica.

\section{CONSIDERAÇÕES FINAIS}

O trabalho aqui relatado objetivou proporcionar ao público uma vivência virtual na Trilha Interpretativa Campus Verde, por meio de uma Trilha elaborada com a temática reciclagem, visando sensibilizar os estudantes com relação ao descarte correto de resíduos e promover a conscientização ambiental. A partir da aplicação da Trilha Virtual consideramos que o trabalho foi significativo para a aprendizagem dos estudantes que visitaram nosso espaço não-formal virtual de ensino, percebendo-se indícios de aprendizagem significativa crítica, como a negociação de significados, a utilização da linguagem própria, a rejeição às certezas e a interação social. Além do envolvimento dos estudantes com a temática trabalhada, percebendo-se como parte integrante a atuante do ambiente que habitam.

Outro aspecto que deve ser considerado é a fecundidade dessa proposta para a nossa formação docente, visto que nos desafiou a planejar, executar e avaliar uma prática de ensino em moldes que ainda não havíamos experimentado, sendo o espaço, o tempo, a linguagem e o nível de ensino novidades em nossas intervenções, nos mostrando a potencialidade das práticas e espaços não-formais de ensino, bem como da importância de adaptação à realidade dos educandos e da linguagem utilizada para a comunicação científica. 
O desafio foi realmente grande, mas acreditamos que foi desenvolvido com sucesso e nos oportunizou uma experiência fantástica, nos deixando mais encorajadas a trabalhar e abordar assuntos relativos à Ciência com diferentes públicos, utilizando metodologias de ensino diversas e desafiadoras.

Diante disso, destacamos a grande importância da Componente Curricular de Estágio em Educação Não-Formal do Curso de Licenciatura em Ciências Biológicas, pois contempla e apresenta aos futuros docentes diversas formas e alternativas de trabalhar em Espaços Não-Formais de Educação, como a experiência que obtivemos em desenvolver uma Trilha Virtual, algo diferente e interessante quando aplicado ao ensino, sobretudo nesse período de adaptação às vivências remotas de ensino-aprendizagem.

Consideramos que esse estudo pode servir de subsídio para trabalhos futuros, que proponham novas metodologias de sensibilização ambiental, bem como de atividades educativas em espaços não-formais de ensino, pois evidenciase que são práticas dinâmicas que podem aprimorar a prática docente, sendo uma estratégia interessante para abordar os assuntos de Ciências e Biologia no âmbito educacional.

\section{REFERÊNCIAS}

BARRETO, A. C. F.; ROCHA, D. S. COVID-19 e Educação: resistências, desafios e (im)possibilidades. Revista Encantar, [S.L.], v. 2, n. 1, p. 01-11, 2020. Disponível em: https://revistas.uneb.br/index.php/encantar/article/view/8480. Acesso em: 18 jun. 2021.

BRANDÃO, C.F. 2004. Estrutura e Funcionamento do Ensino. São Paulo: Editora AVERCAMP, 2004.

BRASIL. Base Nacional Comum Curricular. Brasília: MEC/Secretaria de Educação Básica, 2018. Disponível em: http://portal.mec.gov.br/index. php?option=com_docman \&view=download \&alias $=79601$-anexo-texto-bnccreexportado-pdf-2\&category_slug=dezembro-2017-pdf\&Itemid=30192. Acesso em: 01 jun. 2021.

CESCHINI. M.da S. C. Práticas de Estágio em Educação Não-Formal: Edição Trilha Campus Verde. Disponível em: https://www.canva.com/design/ DAEZJoylf9M/HLnJ1z_O8si9OgCyOhLvyw/view?website\#2:0-site. 
CHASSOT, A. Educação Consciência. 2.ed. Santa Cruz do Sul: Edunisc, 2007. D'ÁVILA. S; QUADRA, G.R. Educação Não-Formal: Qual a sua importância? Revista Brasileira de Zoociências. p. 22-27. 2016. Disponível em: https:// periodicos.ufff.br/index.php/zoociencias/article/view/24644/13817. Acesso em: 25 jun. 2021.

KRASILCHIK, M. Prática de Ensino de Biologia. São Paulo: Editora da Universidade de São Paulo, 2005.

LOUREIRO, C. F. B. Educação Ambiental Transformadora. In LAYRARGUES, P. P. (org.). Identidades da educação ambiental brasileira. Brasília: MMA, 2004 (p.65-84).

MEDEIROS, B A., et al. A Importância da educação ambiental na escola nas séries iniciais. Revista Faculdade Montes Belos, v.4, n. 1, set. 2011.

MINC, C. Ecologia e cidadania. 2 ed. São Paulo: Moderna, 2005.

MOREIRA, M. A. Aprendizaje Significativo Crítico. Indivisa. Boletín de Estúdios e Investigación. $2^{a}$ edição. 2010. Disponível em: https://goo.gl/SwFkKL. Acesso em: 14 jul. 2021.

OLIVEIRA, H. T. de. Educação ambiental - ser ou não ser uma disciplina: essa é a principal questão?! In: Vamos cuidar do Brasil: conceitos e práticas em educação ambiental na escola. Ministério da Educação/MEC - Departamento de Educação Ambiental. Brasília: UNESCO, 2007. Disponível em: http://portal.mec. gov.br/dmdocuments/publicacao3.pdf. Acesso em: 26 mai. 2021.

WOJCIECHOWSKI, T. S. Projetos de educação ambiental no primeiro e no segundo ciclos do ensino fundamental: problemas socioambientais no entorno de escolas municipais de Curitiba. Dissertação de Pós-graduação, Universidade Federal do Paraná, Curitiba, 2006. 
doi $10.48209 / 978-65-89949-12-8$

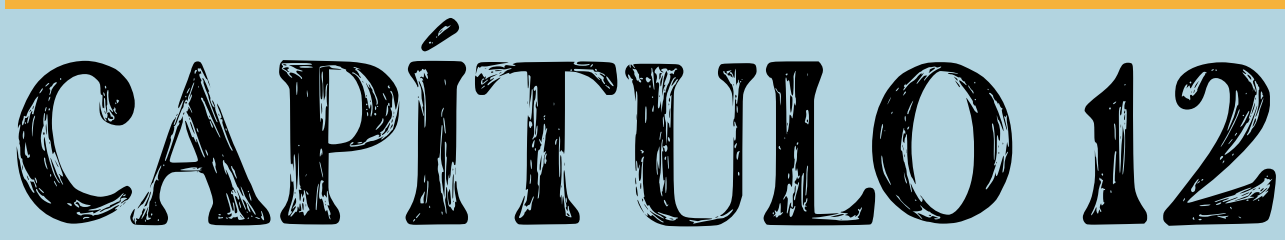

O USO DE RECURSOS DIDÁTICOS DE MIRITI NO ENSINO DE CIÊNCIAS: POSSIBILIDADES EDUCATIVAS NA PANDEMIA DA COVID-19

Ivana Thariny de Lima Leal Priscyla Cristinny Santiago da Luz 


\section{INTRODUÇÃo}

Este estudo consiste em uma investigação sobre as práticas educativas desenvolvidas no ensino de Ciências a partir da utilização de recursos didáticos e tecnológicos. Pensou-se nesta proposta em virtude de ainda hoje ser perceptível a predominância de atividades que limitam a aprendizagem, por exemplo, práticas educativas baseadas em abordagens tradicionais, a carência de recursos didáticos, dentre outros. Para Libâneo (1994), as aulas baseadas apenas no modelo tradicionalista acarretam desmotivação no discente, inviabilizando, assim, a obtenção da aprendizagem.

Conforme a Lei de Diretrizes e bases da Educação Nacional (BRASIL, 1996), o ensino não pode estar preso em apenas repasse de conhecimentos, devendo ter como principal fundamento a formação de cidadãos críticos e ativos no meio social, porém, para que isso aconteça, o professor deve desempenhar seu papel de mediador de saberes com abordagens metodológicas diferenciadas, como por meio da ludicidade, inserção de materiais pedagógicos, investigação e contextualização (LEAL; BRANCO; PEREIRA, 2019).

O desenvolvimento de novas metodologias, métodos de ensino e ferramentas pedagógicas que colaborem com o aprendizado dos estudantes vêm sendo amplamente debatido por Silva e Costa (2013), afirmando que tais alternativas trazem contribuições às práticas educativas de professores de Ciências Naturais, pois os materiais alternativos como os recursos didáticos são imprescindíveis para que os alunos manuseiem e estabeleçam inter-relações com os conteúdos, acarretando a aprendizagem de forma eficiente.

No atual contexto, destacam-se as metodologias ativas (MATTAR, 2017; $\mathrm{BACICH}$; MORAN, 2018) que colocam os alunos como centro da aprendizagem, ou seja, protagonistas do processo e segundo Diesel et al (2017), as metodologias ativas estão apoiadas às tecnologias digitais e correspondem a uma nova modalidade de ensino, que podem colaborar na aquisição de conhecimentos entre os discentes, Assim, torna-se necessário repensar o perfil das aulas, em especial durante a pandemia da COVID-19, bem como o fazer docente apoiado às novas tecnologias aplicadas, visando ressignificar o ensino e aprendizado, por meio da 
exposição crítica, reflexiva e investigativa. E desta maneira, idealizar uma prática pedagógica que promova novas experiências e perspectivas ao ensino remoto.

De acordo com Barbosa et al (2020), o ensino remoto pode ser descrito como atividades pedagógicas em ambiente virtual, que viabilizam estratégias de ação emergencial visando minimizar as problemáticas relacionadas à aprendizagem dos alunos, já que o ano letivo não pode permanecer estático, porque meses estão passando e se faz necessário adequar atividades a esse novo "normal" que está sendo vivido. Nesse sentido, a pesquisa teve por objetivo investigar as contribuições que a aplicação de metodologias que associaram o uso de recursos didáticos (a partir do miriti) e tecnológicos podem propiciar a aprendizagem de conteúdos de Ciências Naturais em tempos de pandemia.

Loureiro e Oliveira (2012) caracterizam a palmeira Mauritia flexuosa ou miritizeiro, como é conhecida popularmente, como um vegetal em abundância na região de Abaetetuba, podendo seu tamanho variar de 30 a 50 metros, tendo diversas utilidades, como: produção de artesanatos, construção de casas e até mesmo subsistência, com fruto de sabor peculiar e múltiplas possibilidades de uso e da mesma forma ressaltam "a importância didática e pedagógica dos brinquedos de miriti" (LOUREIRO; OLIVEIRA, 2012, p. 10), pois esses recursos invadem o imaginário de quem o observa. Suas cores e formas são expressões de uma cultura a qual é evidenciada a cada simples olhar, trazendo ao contexto do aluno elementos da cultura local e da sua realidade.

\section{PROCEDIMENTOS METODOLÓGICOS}

Este estudo é qualitativo de natureza exploratória e foi desenvolvido com alunos do $7^{\circ}$ ano do Ensino Fundamental de uma escola pública no município de Abaetetuba, estado do Pará. A pesquisa foi aplicada a um total de 48 discentes de quatro turmas, sendo duas do turno matutino e duas do vespertino.

As propostas educativas desenvolvidas basearam-se na metodologia ativa de ensino, defendida por Diesel et al (2017, p. 8), na qual "a teorização deixa de ser um ponto de partida e passa a ser um ponto de chegada". O discente, portanto, é tido como sujeito histórico da aprendizagem e ao dar ênfase na tecnologia informacional aplicada à educação percebe-se melhor desempenho de cognições dos alunos. 
Considerando a questão, foram produzidos materiais didáticos a partir da matéria do miriti (matéria-prima oriunda da Mauritia flexuosa) e foram utilizadas também as tecnologias educacionais, no intuito de mediar o processo da aprendizagem. As ações elaboradas (atividades/aulas) foram estruturadas a partir das seguintes temáticas: seres humanos e suas relações com os impactos ambientais; fenômenos naturais e artificiais; biomas brasileiros; vacinação, diferenciação das partículas virais e suas influências no ser humano e a destruição da camada de ozônio.

As atividades foram gravadas e postadas em um canal na plataforma digital YouTube. Esse canal foi disponibilizado para os discentes por meio de links nos grupos do WhatsApp. A cada ação foi solicitado o preenchimento de um formulário pré e pós, visando diagnosticar os conhecimentos dos educandos. Os dados coletados foram analisados a partir da análise de conteúdo proposto por Bardin (2011).

\section{Atividades desenvolvidas}

A primeira atividade realizada foi sobre a temática "Seres humanos e suas relações com os impactos ambientais", em que se utilizou o seguinte material didático, figura 1.

Figura 1: Cidade montada apresentando a poluição causada pelas ações humanas.

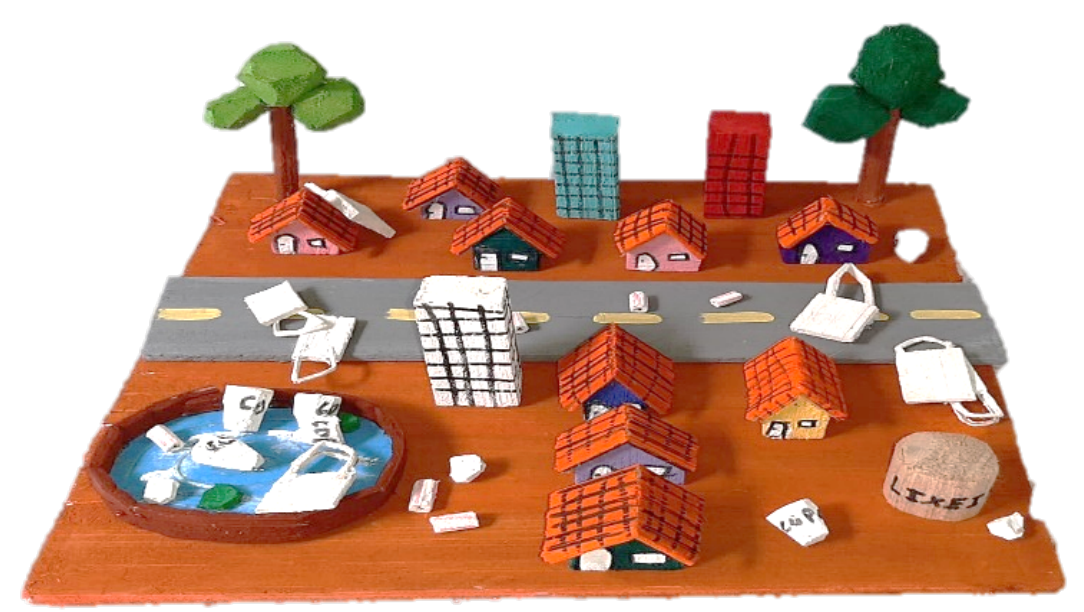

Fonte: (LEAL; LUZ, 2021). 
Em um primeiro momento, problematizou-se sobre o assunto: Qual papel o cidadão deve desempenhar em meio às problemáticas ambientais? Na sequência, foram expostas peças confeccionadas de miriti como: árvores, prédios, carros, casas, ruas, lixos, entre outros elementos, para os discentes imaginarem como essas peças estariam em seu contexto de modelo de cidade que vivenciam em seu município, sendo construído um para exemplificação a eles.

Essa atividade foi disponibilizada aos discentes por meio de links, assim como os exemplares das cartilhas Recicléia adote essa ideia, que tratam sobre os temas - lixo (FERNANDES,2006); desmatamento; (FERNANDES, 2010) e água para se comer (FERNANDES,2011) os quais foram solicitados para realização da leitura e anotação sobre o que foi entendido, a fim de que os alunos explanassem sobre o questionamento proposto.

Similarmente, foram apresentadas as cartilhas durante a aula em formato de mapa mental para discussão e entendimento da questão proposta na atividade. Assim foram feitas considerações a partir das leituras, associando-as com as situações descritas e visualizadas na montagem da cidade, momento que aconteceu a mediação entre os saberes cotidianos e científicos.

Como método avaliativo foi disponibilizado um formulário pré aula e um pós, contendo questões abertas e fechadas (alternativas e discursivas) para os estudantes apresentarem os conhecimentos sobre o tema estudado. Esse procedimento foi utilizado também nas demais aulas.

A segunda aula foi sobre o tema "Fenômenos naturais e artificiais" e os recursos didáticos aplicados podem ser visualizados na figura 2 .

Figura 2: Material da aula dois sobre fenômenos.

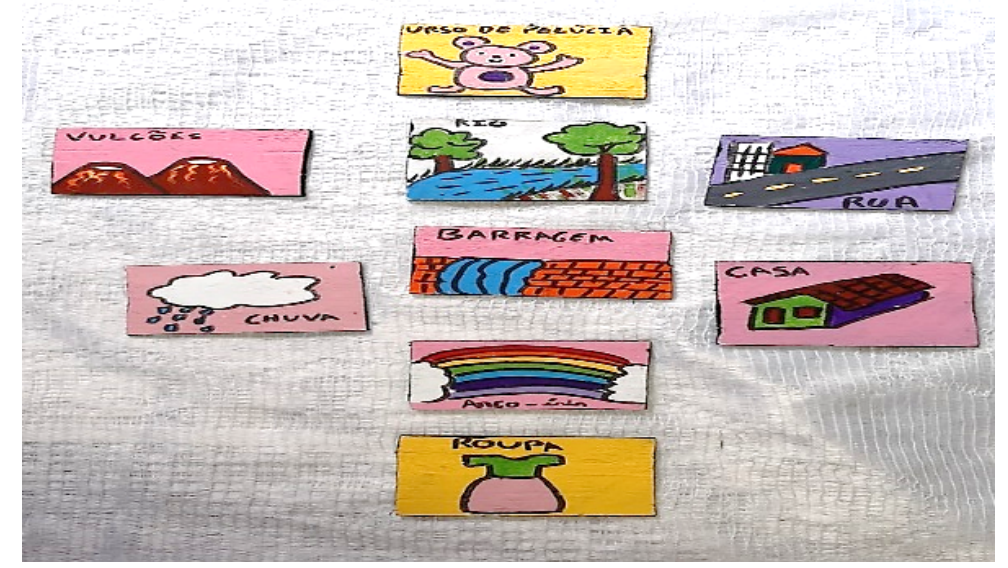

Fonte: (LEAL; LUZ, 2021). 
A priori foi levantado o problema: Quais as relações os seres humanos desempenham para o acontecimento de fenômenos no planeta? Depois foram apresentadas peças elaboradas a partir da palmeira do miriti compostas pelos seguintes desenhos: arco-íris, vulcões, chuva, rios, urso de pelúcia, roupas, casas, barragens e ruas, os quais estão expressos na figura 2.

Dando seguimento à aula foi solicitado aos educandos que realizassem pesquisas sobre os fenômenos relacionados às imagens distribuídas, para que anotassem e formulassem suas compreensões. Posteriormente foi solicitado que os alunos relacionassem com fenômenos percebidos em seu cotidiano, por exemplo, seu trajeto até chegar à escola. Em seguida foi realizada a mediação dos saberes. Esse momento possibilitou esclarecimentos e debates acerca da questão norteadora, a partir da exposição dos conhecimentos científicos (CARVALHO,1998).

Na terceira aula, o tema selecionado foi "Os biomas brasileiros", representados na figura 3.

Figura 3: Modelo representativo dos biomas brasileiros

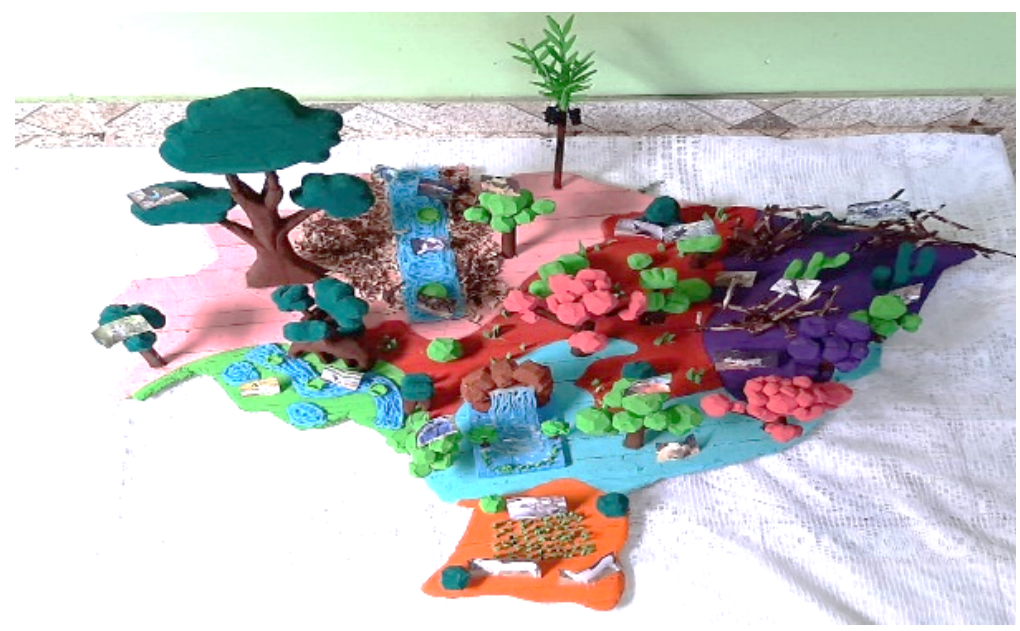

Fonte: (LEAL; LUZ, 2021).

Inicialmente, foram problematizadas as seguintes questões: Quais fatores influenciam na estrutura, no funcionamento e sucesso de um bioma? Quais relações são estabelecidas pelo ser humano que podem contribuir para o equilíbrio dos biomas e da conservação da diversidade biológica? Em seguida, foi proposta a realização de pesquisas sobre a temática, e na sequência foi apresentado um modelo ilustrativo, figura 3 , em que foram destacados (com colorações diferen- 
tes) os biomas brasileiros, contendo os principais representantes da fauna e flora específica.

Da mesma maneira, foi solicitado aos educandos que identificassem organismos da fauna e flora encontradas em seu município. Foi feito um levantamento, inclusive, das árvores e dos animais que os alunos já ouviram falar, já viram na TV ou em filmes, sendo essas espécies diferentes do que encontram em sua realidade local. Logo após, foram acrescentadas explicações acerca da temática visando estabelecer novas discussões aos educandos sobre o assunto.

$\mathrm{Na}$ quarta atividade abordou-se sobre o tema "Vacinação, diferenciação das partículas virais e suas influências no ser humano". Essa atividade teve como aporte os seguintes materiais, como mostra a figura 4 .

Figura 4: Morfologias virais.

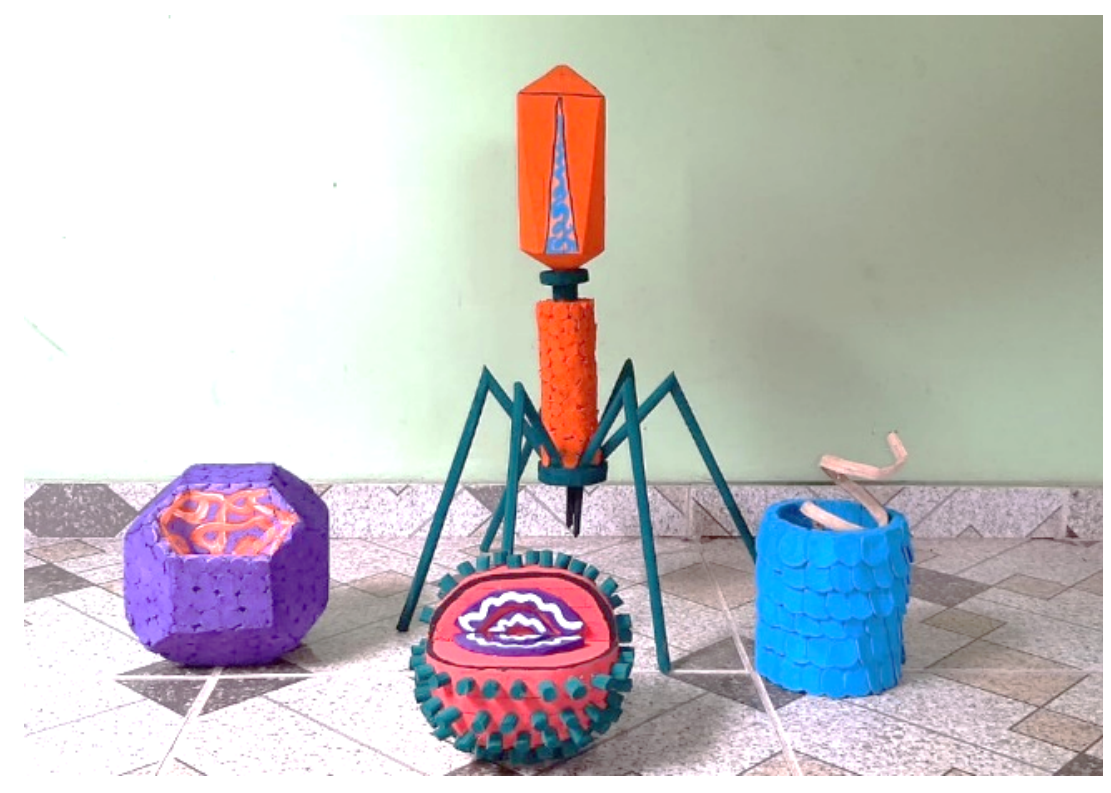

Fonte: (LEAL; LUZ, 2021).

Para iniciar a aula foi feita a seguinte indagação: Quais as relações que podem ser evidenciadas entre os vírus e o meio ambiente e como essas relações podem interferir na vida dos seres humanos? Após esse momento, foram mostrados modelos representativos elaborados de miriti das seguintes partículas virais explícitas acima: helicoidal, envelopado, poliédrico e bacteriófago, sendo solicitado aos alunos que anotassem as diferenças encontradas nas estruturas. Da mesma forma foi proposto que expusessem a respeito do ciclo de infecção causada por vírus no ser humano. 
Posteriormente, explanou-se sobre o histórico da vacinação e como a vacina é desempenhada no organismo. Ao final da atividade solicitou-se que os estudantes respondessem à questão norteadora. Nesse momento aconteceu a mediação entre os saberes trabalhados.

Na última aula, foi discutido o tema "Destruição da camada de ozônio" apoiando-se no seguinte recurso pedagógico, como mostra a figura 5.

Figura 5: Representação da camada de ozônio.

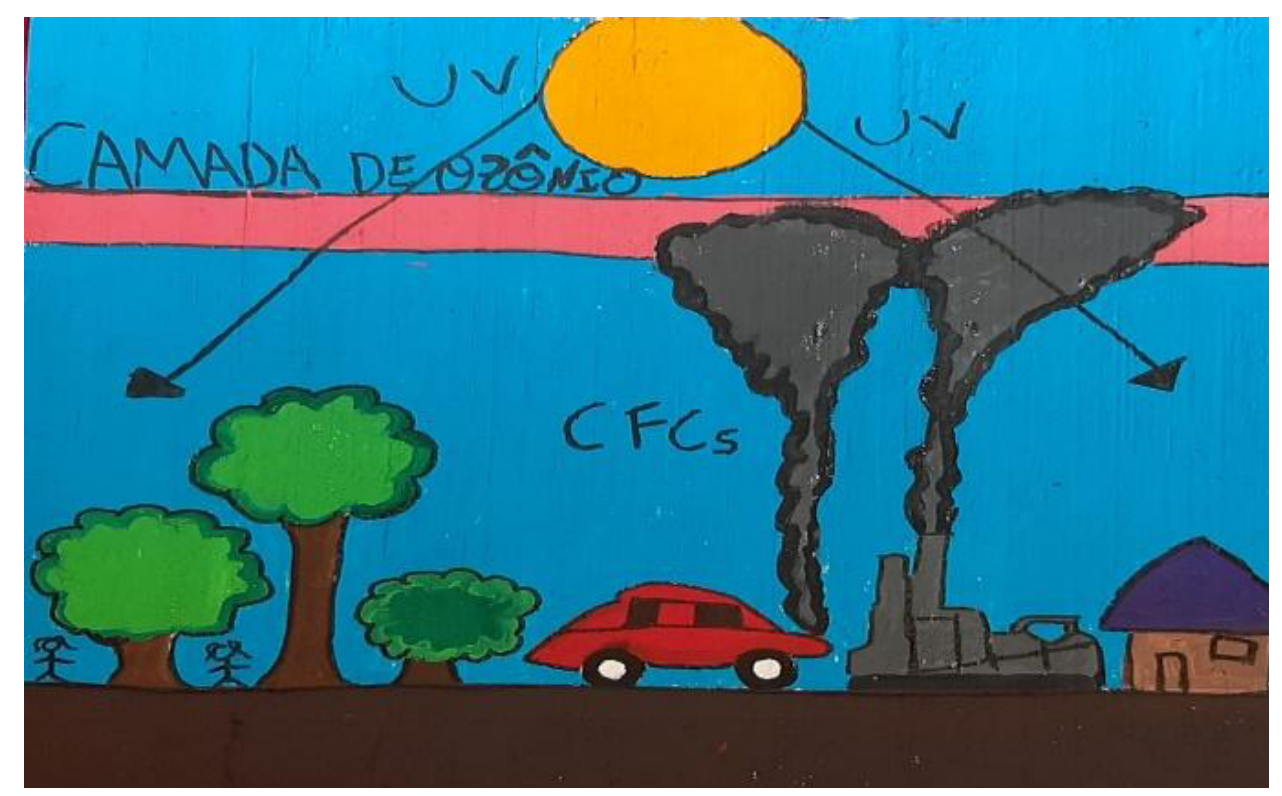

Fonte: (LEAL; LUZ, 2021).

Para iniciar a aula apresentou-se a problematização: Qual a relação existente entre a influência do ser humano, camada de ozônio e vida no planeta? Em seguida, foram demonstrados aos estudantes o modelo didático anterior de miriti que representa a camada de ozônio e os poluentes que a afetam, infiltração dos raios Ultravioleta no planeta Terra.

$\mathrm{Na}$ sequência, foi apresentado um vídeo em desenho animado intitulado de Ozzy Ozônio: Proteção da Camada de Ozônio, criado pela Organização das Nações Unidas (ONU) Meio Ambiente e TVE Internacional, no ano de 2003. O audiovisual retrata a degradação da camada de ozônio, os raios ultravioletas e suas implicações sobre a pele humana (ONU, 2003).

Após a exibição, discutiu-se o vídeo associando ao recurso didático para resolução da problemática e ocorreu também a interação entre os conhecimentos científicos, buscando realizar debate sobre a influência da relação ser humano sociedade, ser humano patrimônio e ser humano cidadania para a formação de novos hábitos socioambientais. 


\section{RESULTADOS E DISCUSSÃO}

Para realização da análise os resultados foram organizados nas seguintes categorias: Metodologias ativas, recursos pedagógicos de miriti e tecnológicos para aprendizagem de Ciências Naturais e Aprendizagem desenvolvida nas aulas virtuais.

\subsection{Metodologias Ativas, Recursos Pedagógicos de Miriti e Tecnológicos para Aprendizagem de Ciências Naturais}

As metodologias ativas contribuem para trazer momentos reflexivos sobre os fenômenos existentes na natureza e a relação do patrimônio cultural, sociedade e meio ambiente. Nesse sentido, como Santos e Machado (2018) inferem, o ensino deve transpor a mecanicidade de obtenção de conteúdo, sendo imprescindível proporcionar a alfabetização científica aos alunos através da internalização dos saberes.

De igual forma, consideramos que a valorização da cultura regional, por meio de recursos de miriti, compreende um importante resgate histórico da cultura abaetetubense e uma forma lúdica de ensinar Ciências. Nessa relação considera-se que "a metodologia baseada na ludicidade contribui de forma significativa nas aulas de Ciências, porque possibilita aos alunos a interação, raciocínio, interpretação, dentre outros fatores importantes para a aprendizagem" (LEAL, BRANCO, PEREIRA, 2019, p. 55).

No contexto exposto, para trazer a cultura regional do Pará, utilizou-se a palmeira do miriti, na qual podem ser extraídos seus pecíolos (braços), não agredindo a planta nem a natureza. Consideramos que a elaboração de materiais didáticos a partir do miriti permitiu aproximar "a cultura local do currículo escolar pré-estabelecido, pois sempre ocorre a omissão de elementos culturais, ou seja, alguns conhecimentos são priorizados em detrimento de outros" (GONÇALVES, 2019, p. 31).

Um dos educandos fez o seguinte relato no grupo da turma no WhatsApp, ao assistir a aula, em que ocorreu a montagem de uma cidade feita a partir da matéria prima do miriti: "Achei muito legal esses objetos de miriti. Eu sempre vejo brinquedos feitos assim no festival do miriti que tem todos os anos aqui na 
cidade, mas nunca vi na escola". Verifica-se no relato do estudante que os recursos didáticos de miriti não estão presentes no contexto das escolas paraenses em específico em Abaetetuba, considerada a capital mundial do brinquedo de miriti. O município deveria ser o maior propagador e valorizador desse material nas ações educativas e nesse olhar, se torna de grande importância oferecer a construção científica a partir de práticas pedagógicas viabilizando aos estudantes momentos contextualizados e sintonizados ao processo de ensino e aprendizagem, superando o ensino tradicional com apenas repasse de informações.

Nas atividades realizadas estimulou-se a participação, reflexão e a iniciativa dos estudantes, no entanto, constatou-se que apesar do interesse e da interação (seja com o recurso produzido e devido ao acesso às tecnologias, que foi bastante estimulante na opinião dos estudantes) o ensino remoto foi limitante para a construção de atitudes mais concretas entre os alunos e de serem acompanhadas, ou seja, do protagonismo na aprendizagem, relação que talvez em uma prática educativa híbrida ou presencial teria maior potencial na assimilação dos conhecimentos estudados.

\subsection{Aprendizagem desenvolvida nas aulas virtuais}

As tecnologias disponíveis no ambiente virtual são ferramentas cada vez mais utilizadas no dia a dia de crianças, adolescentes e jovens, em que geralmente ocorre o compartilhamento em larga escala de informações e neste entendimento, Oliveira et al. (2020) asseguram que para os discentes assumirem uma postura autônoma em seu processo de aprendizagem, deve-se haver nas escolas propostas alternativas que agreguem o ambiente educativo, já que os alunos passam grande parte de seu tempo com celulares e computadores acessando diversas plataformas e redes sociais.

Contudo, vale ressaltar que para a tecnologia educativa surtir efeitos positivos na aprendizagem se faz necessário um mediador que promova a interação entre os conhecimentos a serem aprendidos, sendo este o profissional da educação, exercendo um papel fundamental na construção de saberes científicos. Essas ideias condizem com o que expõe Santos (2010), para o qual o docente faz o intermédio dos conhecimentos por meio de suas ferramentas educativas e maneiras de ensinar. Assim, ao utilizar o meio tecnológico em classe consequentemente resultados benéficos serão desencadeados. 
Nesse ínterim, quando essa pesquisa foi direcionada aos estudantes das turmas do $7^{\circ}$ ano, totalizando 48 participantes, pode-se perceber que no primeiro momento (observando os formulários e reações dos alunos) verificou-se certa estranheza a respeito da metodologia aplicada, ao expor as aulas por meio do YouTube, plataforma que disponibiliza uma vasta gama de vídeos e materiais contendo diversos assuntos educativos. $E$ apesar desses recursos estarem abertos ao público, não é comum solicitar à classe que busque esses canais como material complementar às aulas. No geral, a internet é usada em pesquisas independentes para tirar dúvidas ou para o entretenimento.

Muitos relatos foram adicionados pelos alunos nos grupos de turma do WhatsApp, espaço em que foram disponibilizados os links de acesso às atividades. Um dos estudantes escreveu: " muito legal esse vidio pq posso ve a hora $q$ quero diferente da escola que o professor passa o assunto muito rápido e agente ainda nem aprendeu", ou seja, ele afirmou que a proposta de videoaulas era uma prática bem diferente do que os alunos estavam habituados a fazer, considerando a atividade da aula interessante e dinâmica, porque, ele poderia ter acesso a ela a hora que quisesse diferente do ensino somente presencial que o professor só ministrava uma vez o conteúdo e no outro dia era um assunto totalmente distinto.

Durante as cinco aulas ministradas verificou-se ainda especificidades a respeito do nível de conhecimento adquirido depois da atividade ministrada via YouTube, em que foi facilitada a compreensão dos assuntos estudados. A seguir destacamos o que foi construído cognitivamente nas respostas dos formulários.

$\mathrm{Na}$ aula 1- Seres humanos e suas relações sobre os impactos ambientais, obteve-se como resultados a compreensão de como os alunos entendiam a poluição e seus agentes causadores, pois nos primeiros formulários verificou-se poucos esclarecimentos a respeito do tema, visto que em alguns casos os estudantes marcaram questões que afirmavam a reciclagem de materiais como um fator causador de propagação de poluição no planeta. Assim como alguns educandos não souberam classificar o que seria, exibindo respostas vagas ou incoerentes.

Todavia, ao ser aplicado o segundo formulário pode-se evidenciar a diferença nas respostas, que já trazia a sensibilização socioambiental, como é evidenciado quando os discentes indicaram que tinham visto em seu cotidiano inúmeros exemplos de poluições e tais eram problemáticas desenvolvidas pelas 
ações inconscientes dos seres humanos, elencando da mesma forma maneiras de se evitar a poluição no planeta como: "Conservar o meio ambiente" e "Cobrar dos gestores atitudes que possibilitem a manutenção do ambiente conservado e preservado".

É importante destacar que os estudantes afirmaram através do grupo da turma que gostaram da dinâmica da primeira aula, pois ela possibilitou a visualização de objetos (recursos de miriti), os quais fizeram os alunos pensarem a respeito do que estava sendo aprendido, como assevera Bruner (1978). Segundo o autor, quando as aulas possuem cunho lúdico a compreensão do que está sendo estudado é oportunizada de forma abrangente e diversificada.

Já a aula 2 que teve como foco debater sobre os fenômenos naturais e artificiais, foi perceptível nas primeiras impressões que os educandos apresentam poucos conhecimentos a respeito do que seria um fenômeno, similarmente, não conheciam as diferenças estabelecidas entre os naturais e artificiais, como pode ser visualizado no gráfico abaixo, em que pode ser feito uma comparação entre a compreensão antes e depois da atividade.

Gráfico 1: Questão relacionada aos fenômenos naturais e fenômenos artificiais evidenciados nas respostas dos alunos. Os tópicos presentes no eixo x correspondem às alternativas disponibilizadas para os discentes marcarem no formulário.

\section{- Antes Depois}

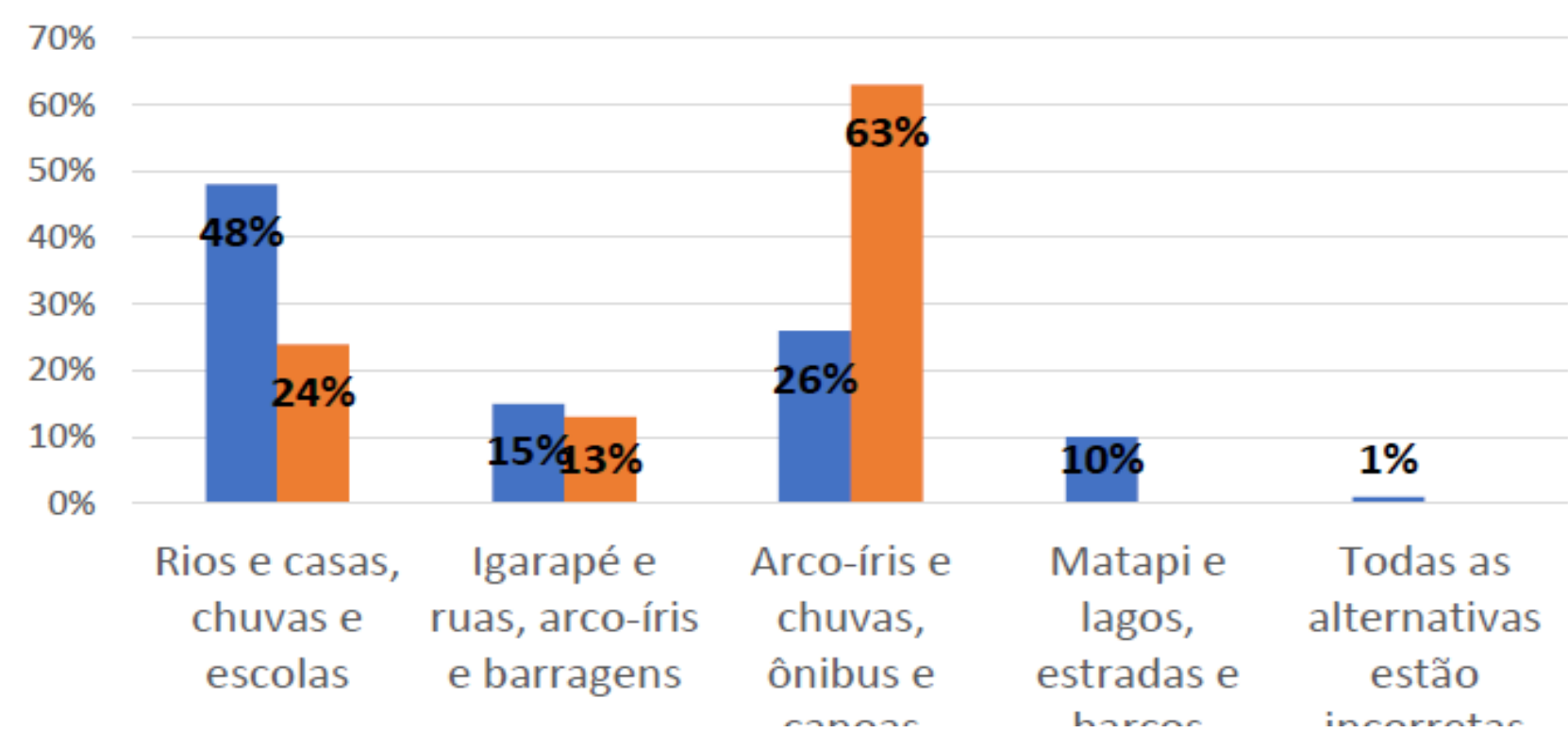

Fonte: Pesquisa de campo (LEAL, 2021). 
O gráfico 1 aponta que a maioria dos alunos não sabiam distinguir os fenômenos naturais dos artificiais, pois somente $26 \%$ da turma acertou a questão, o que leva a uma reflexão sobre o papel do ensino de Ciências na formação de sujeitos alfabetizados cientificamente. Cunha (2017) relata a necessidade da alfabetização científica nas escolas brasileiras, porque esta vem trazer uma nova perspectiva de aprendizagem embasada no rompimento de conceitos pré-estabelecidos e decorativos que caracterizam a Ciência como imutável e o letramento científico apresenta-se também como anseio na formação dos estudantes, visto que busca integrar o conhecimento científico aos fenômenos vividos cotidianamente, obtendo assim novas concepções para a explicação do mundo por meio de conclusões estabelecidas por evidências. (CUNHA, 2017)

Ao fazer um comparativo é possível constatar o aumento da taxa de estudantes a assinalar a seção correta, pois $63 \%$ da classe conseguiu compreender os fenômenos em seu dia a dia e realizar a diferenciação dos fenômenos a partir da assimilação do assunto estudado.

A terceira aula tratou sobre os biomas brasileiros e nessa proposta foram destacados aos estudantes o que é e como se constitui a fauna, flora, os diferentes tipos de solo, as relações entre ser humano e bioma, além de serem destacados pontos concernentes aos fatores de desequilíbrio ecológico, queimadas, desmatamento, entre outros. Dessa forma, serão explanadas algumas respostas obtidas nos formulários sobre os biomas brasileiros no quadro abaixo:

Quadro 3: Respostas na íntegra dos alunos das turmas do $7^{\circ}$ ano sobre a compreensão de como as relações são estabelecidas pelo ser humano para o equilíbrio dos biomas e manutenção/conservação da diversidade biológica.

\begin{tabular}{|c|c|c|}
\hline Estudante & $\begin{array}{l}\text { Formulário aplicado } \\
\text { antes da aula }\end{array}$ & Formulário aplicado depois da aula \\
\hline Ametista & $\begin{array}{l}\text { A mudança de um país } \\
\text { melhor }\end{array}$ & $\begin{array}{l}\text { A conservação da natureza, da vida animal, } \\
\text { reflorestamento e outros. }\end{array}$ \\
\hline Rubi & Sim & $\begin{array}{c}\text { Desenvolvimento Sustentável e Preservar a } \\
\text { Natureza }\end{array}$ \\
\hline Esmeralda & As ruas & $\begin{array}{l}\text { A melhor maneira de proteger o bioma ou } \\
\text { seja amazônica é impedir seu desmatamento. } \\
\text { Sobre diversidade biológica é salvar nossas } \\
\text { florestas comprando da boa madeira, comprar } \\
\text { pescados sustentável etc... }\end{array}$ \\
\hline
\end{tabular}


O ENSINO DE CIENCLIAS NO BRASIL DURANTE E APÓS A PANDEMIA DA COVID-19: PERSPECTIVAS, DESAFIOS E POSSIBILIDADES

\begin{tabular}{|c|c|c|}
\hline Jade & Não sei & $\begin{array}{c}\text { Preservando o planeta que vivemos não } \\
\text { poluindo, não fazendo caça aos animais } \\
\text { silvestres, não poluindo o meio ambiente. }\end{array}$ \\
\hline Topázio & $\begin{array}{c}\text { A Parceria Dos Trabalhado- } \\
\text { res }\end{array}$ & $\begin{array}{r}\text { Evitando queimadas, ser gentil no trânsito, } \\
\text { respeita a sinalização e os limites de } \\
\text { velocidade ações como esta evita o } \\
\text { atropelamento de pessoas e animais silvestre. } \\
\text { podemos plantar arvores nativas e frutíferas. } \\
\text { utilizar outras fontes de energia q nao seja } \\
\text { queimada da madeira }\end{array}$ \\
\hline
\end{tabular}

Fonte: (LEAL; LUZ, 2021).

A partir do que foi apresentado no quadro 3, evidencia-se que os educandos não refletiam sobre como o ser humano pode vir a contribuir para o equilíbrio dos biomas e conservação da imensa variabilidade biológica existente, pois em suas respostas percebeu-se a nítida a confusão de ideias, mostrando assim a carência de informação.

No entanto, nas respostas de Esmeralda após a aula evidenciou-se mudança significativa na compreensão do tema, já que no primeiro formulário foi afirmado que a construção de ruas auxiliava na manutenção da diversidade biológica, contrariando o que foi escrito no segundo. Notou-se a inclusão de pensamentos relacionados à natureza, ao ser humano, citando sobre o desmatamento que pode vir a causar danos para a diversidade biológica. Também foi discorrido sobre sustentabilidade e consumo consciente.

Da mesma maneira, as questões respondidas por Jade apresentaram respostas bastante diferentes nos formulários aplicados. No primeiro formulário a estudante informou não ter conhecimento do conteúdo ao responder "não sei", entretanto ao analisar o segundo formulário deparou-se com uma realidade totalmente distinta, em que a estudante apontou elementos e relações acerca da preservação ambiental, como: "se faz necessário preservar o planeta Terra, evitar a poluição e a caça de animais silvestres".

Nas argumentações de Topázio verifica-se também pouca apropriação do tema. Em sua resposta preliminar foi destacada "A parceria dos Trabalhadores", ao apresentar uma descrição vaga sobre o assunto. Mas ao ser explanado o tema no formulário seguinte foram diagnosticadas relações mais esclarecidas, 
visto que a discente argumentou que essa relação está diretamente relacionada às atitudes conscientes do homem, apontando a importância de plantar árvores, evitar as queimadas e preservar animais silvestres.

De modo geral, o aprofundamento teórico gerado nessa aula possibilitou que os educandos formassem novas concepções através de reflexões sobre o seu cotidiano. Neste entendimento, sustenta-se que o embasamento promovido pelos conteúdos propostos na BNCC reverbera nas atitudes dos alunos, para que valorizem a coletividade, responsabilidade e tomada de decisões, além de serem refletidas atitudes sustentáveis e solidárias (BRASIL, 2017).

A quarta aula teve como tema: Vacinação, diferenciação das partículas virais e suas influências no ser humano. Os educandos conheceram sobre a saúde pública e a importância da vacinação para os indivíduos e como a vacina atua no organismo, além de serem elencados os contextos histórico, social e cultural. O quadro 4 destaca as respostas dos estudantes.

Quadro 4: Compreensão sobre saúde pública e cidadania.

\begin{tabular}{|c|c|c|}
\hline Aluno & $\begin{array}{c}\text { Formulário antecedente } \\
\text { a atividade }\end{array}$ & Formulário posterior à atividade \\
\hline Afrodite & Não sei & $\begin{array}{l}\text { Medidas de desenvolver a Saúde do cidadão, } \\
\text { direitos de ter atendimentos de qualidade, } \\
\text { Profissionais, medicamentos }\end{array}$ \\
\hline Apolo & Não sei & $\begin{array}{l}\text { Se trata de todo conjuntos de medidas } \\
\text { Executados pelo estado para garantir o } \\
\text { bem-estar físico, mental e social da população }\end{array}$ \\
\hline Ares & Não sei & $\begin{array}{c}\text { Saúde pública na concepção mais tradicional, } \\
\text { e a aplicação de conhecimentos, } \\
\text { com o objetivo de organiza }\end{array}$ \\
\hline Atena & $\ldots$ & $\begin{array}{c}\text { Saúde e cuidado hospitalar, meio ambiente } \\
\text { limpo e conservado, cuidados pessoais } \\
\text { e coletivos ajudam a não propagação de } \\
\text { doenças virais e não virais. }\end{array}$ \\
\hline Hércules & $\begin{array}{l}\text { É porque não precisa pagar } \\
\text { dinheiro, porque é público } \\
\text { todos podem ir lá }\end{array}$ & $\begin{array}{c}\text { Seriam medidas de governo eles vão fazer com } \\
\text { que desenvolvam meios de preservar } \\
\text { a saúde dos cidadãos. }\end{array}$ \\
\hline
\end{tabular}

Fonte: (LEAL; LUZ, 2021). 
A partir do exposto, verifica-se na resposta de Hércules que o entendimento dele sobre a temática se restringe a não pagar por serviços ofertados, já que o sistema é público. Entretanto, ele não concebe uma explicação coerente sobre o assunto. Todavia, ao serem analisadas as respostas preenchidas no segundo formulário identificou-se o aprofundamento sobre estas questões destacando a importância de ações governamentais para preservação da saúde coletiva.

Para Freire (2008), é importante realizar um levantamento de dados empíricos a partir das experiências vividas pelos alunos relacionando ao tema em questão, assim como foi feito durante essa aula, para dessa maneira disseminar os conhecimentos científicos. Essa pesquisa trouxe a evolução da compreensão entre os estudantes, já que "houve aprendizagem pois houve aumento no nível de proficiência dos alunos e diminuição do índice de dificuldade dos itens" (CASTRO, 2017, p. 146).

A última aula aplicada foi sobre a destruição da camada de ozônio. Nessa atividade, percebeu-se que os alunos já tinham alguns conhecimentos prévios sobre o tema, todavia, eles não sabiam explicar o que seria e qual sua importância para o planeta, e nem como era promovida sua degradação. Da mesma forma, ao serem questionados sobre qual a importância do estímulo da vitamina D no organismo eles não souberam responder, mas depois da aula foi acarretada a ressignificação da temática e o processo de ensino e aprendizagem foi ocasionado.

Associando as cinco aulas aplicadas às quatro turmas do $7^{\circ}$ ano, pode-se afirmar que os materiais (recursos didáticos e tecnológicos) juntamente com as bases das metodologias ativas de ensino foram possíveis favorecer a construção de aprendizagens sobre os conteúdos de Ciências Naturais em tempos de pandemia.

Oliveira (2015) afirma que a construção da aprendizagem deve promover o impulso por meio do ensino, levando o discente a se dedicar nas ações e no desenvolvimento de suas capacidades cognitivas e sociais. Nesse entendimento, o profissional da educação possui papel preponderante em sua prática educativa e dessa forma, o olhar docente frente às especificidades dos discentes e do contexto social torna-se de suma importância no desenvolvimento dessa mediação dos saberes para promoção de métodos efetivos para o desenrolar da aprendi- 
zagem, sendo este responsável por transformar as ideologias sociais, assim, o modo como atua se torna decisivo para propiciar autonomia dos discentes. (LIBÂNEO,1994).

\section{CONSIDERAÇÕES FINAIS}

No desenvolvimento da pesquisa, verificou-se que o uso de metodologias ativas, associadas ao uso de recursos didáticos produzidos a partir da matéria-prima da palmeira do miriti e das tecnologias educacionais, consolidaram uma estratégia educativa que, a nosso ver, é promissora para o processo de ensino e aprendizagem em Ciências Naturais, principalmente em tempos de pandemia.

Nesse estudo, constatou-se que as cinco vídeoaulas disponibilizadas pelo canal do YouTube estimularam os educandos a aprender Ciências e se sensibilizar sobre o meio ambiente e as consequências acarretadas pelos maus hábitos dos seres humanos e similarmente, a cultura regional foi fomentada nas atividades através da inserção de recursos didáticos pautados na matéria-prima do miriti. Vale ressaltar que essa investigação possibilitou a construção de saberes entre os educandos dos $7^{\circ}$ anos da instituição de ensino. E assim, estimulou a formação de novas concepções sobre as temáticas socioambientais estudadas.

Ao serem feitas as análises dos dados obtidos por meio dos formulários pré e pós aulas, foi evidenciado que grande parte dos estudantes detinham poucas informações sobre os assuntos abordados e que com as atividades realizadas passaram a construir novas relações, chegando a construir relações críticas e reflexivas sobre os assuntos estudados e assim, esse estudo mostrou-se valoroso no aprendizado de Ciências Naturais, possibilitando práticas educativas alternativas que podem ser desenvolvidas com turmas da educação básica. E a partir dessa experiência tem-se a convicção de que este estudo pode ser replicado a outras escolas e traga novas contribuições à prática docente e à aprendizagem científica dos alunos. 


\section{REFERÊNCIAS}

BACICH, L; MORAN, J. Metodologias ativas para uma educação inovadora: uma abordagem teórico-prática. Porto Alegre: penso, 2018.

BRASIL, Base Nacional Comum Curricular: Educação e Base. Brasília, 2017. . Lei n. 9394, de 20 de dezembro de 1996. Lei de Diretrizes e Bases da Educação Nacional. Brasília: MEC, 1996.

BARDIN, L. Análise de conteúdo. São Paulo: Edições, 2011.

BARBOSA, A. T; FERREIRA, G. L; KATO, D. S. O ensino remoto emergencial de Ciências e Biologia em tempos de pandemia: com a palavra as professoras da Regional 4 da Sbenbio (MG/GO/TO/DF). Revista De Ensino De Biologia Da SBEnBio, 13(2), 379-399. https://doi.org/10.46667/renbio.v13i2.396, 2020.

BRUNER, J. S; RATNER, N. Games, Social Exchange and the Acquisition of Language, In: Journal of child Language. v. 5, n. 3, p. 401, 1978.

CASTRO, F. Universidade Federal da Bahia Universidade Estadual de Feira e Santana Programa de Pós-Graduação em ensino, filosofia e história das Ciências. [s.l.: s.n., s.d.], 2017. Disponível em: <https://repositorio.ufba.br/ ri/bitstream/ri/24943/1/TESE\%20FERNANDA\%20REGEBE\%20PPGEFHC\%20 FINAL\%20REPOSITORIO.pdf>. Acesso em: 16 jan. 2021.

CARVALHO, A. M. P; VANNUCI, A. I; BARROS, M. A; GONÇALVES, M. E. R; REY, R. C. Ciências no ensino fundamental: o conhecimento físico. São Paulo: Scipione, 1998.

CUNHA, R. B. Alfabetização científica ou letramento científico?: interesses envolvidos nas interpretações da noção de scientific literacy. Revista Brasileira de Educação, v. 22, n. 68, p. 169-186, 2017. Disponível em: <https://www.scielo.br/scielo.php?pid=S1413-782017000100169\&script=sci_arttext $>$. Acesso em: 15 Jan. 2021.

DIESEL, A ; BALDEZ A. L. S; MARTINS, S. N. Os princípios das metodologias ativas de ensino: uma abordagem teórica. Revista Thema: Rio Grande do Sul, v.14, n. 1, 2017.

FERNANDES, M. L. O. (Org.) Recicléia lixo. [S.I.:s.n], 2006. Disponível em: <https://19263bd9-bfae-499b-96dd-41caab787366. filesusr.com/ugd/d9fa2c_92417e4161584cdc937600d8df40b19f.pdf>. Acesso em: 25 out. 2019. 
. Recicléia Amazônia eu te quero verde. [S.I.:s.n], 2010. Disponível em: <https://19263bd9-bfae-499b-96dd-41caab787366.filesusr.com/ugd/d9fa2c_5e2886a899a94b2bb5d40df21b25b83f.pdf>. Acesso em: 25 out. 2019.

Recicléia água para se comer. [S.I.:s.n], 2011. Disponível em: <https://19263bd9-bfae-499b-96dd-41caab787366.filesusr.com/ugd/d9fa2c_ b11b74e83ec3441a8a5001725b7ca446.pdf>. Acesso em: 25 out. 2019.

FREIRE, P. R. N. Pedagogia do Oprimido. Rio de Janeiro: Paz e Terra, 2008.

GONÇALVES, I. C. L. O brinquedo de miriti como prática pedagógica-cultural: Representações e identidade. Trabalho de conclusão de curso (graduação em Pedagogia) Universidade Federal do Pará. Abaetetuba, 2019.

LEAL, I. T. L; BRANCO, A. C. S; PEREIRA, E. L. Verificando a formação docente quanto à abordagem lúdica nas aulas de ciências em uma escola pública de Abaetetuba Pará. VI seminário nacional do grupo de estudos e pesquisa sobre a memória, formação docente e tecnologia, 2019. Disponível em: <http:// www.virtualbooks.com.br>. Acesso em: Acesso em: 16 Jan. 2021.

LIBÂNEO, J. C. Didática. São Paulo: Cortez, 1994.

LOUREIRO, J. P.; OLIVEIRA, J. Da Cor Do Norte: Brinquedos de Miriti. Tradução de Hamilton. Fortaleza: Lumiar Comunicação e Consultoria, 2012.

ORGANIZAÇÃO DAS NAÇÕES UNIDAS, Ozzy Ozônio. Disponível em: https:// youtu.be/Td48TjjrbQU. Acesso em: 07 dez. 2020.

MATTAR. J. Metodologias ativas para educação presencial, blended e a distância. $1^{\text {a }}$ ed. São Paulo: Artesanato educacional, 2017

OLIVEIRA, C.C. S. O uso dos recursos didáticos no ensino de ciências em uma escola pública de governador mangabeira/ba. Trabalho de conclusão de curso (graduação em Biologia) Universidade Federal do Recôncavo da Bahia. Cruz das Almas, 2015.

OLIVEIRA, G; ALMEIDA, V. E; TROTTA, L. M. As tecnologias e o mundo globalizado: reflexões sobre o cotidiano contemporâneo. Educação Pública, v. 20, nº 2, 14 de janeiro de 2020. Disponível em: <https://educacaopublica.cecierj.edu.br/ artigos/20/2/as-tecnologias-e-o-mundo-globalizado-reflexoes-sobre-o-cotidiano-contemporaneo>. Acesso em: 07 dez. 2020. 
SANTOS, E. A. C. O lúdico no processo ensino-aprendizagem. Universidad Tecnológica Intercontinental (Dissertação de mestrado). Assunción, 2010 f. 3-7.

SANTOS, A. C. G. G; MACHADO, V. A pesquisa escolar em aulas de ciências: relatos sobre o desenvolvimento de uma sequência didática baseada no ensino por investigação. In: Encontro Nacional de Ensino de Biologia, 7., 2018, Belém. Anais... Belém: SBenBio, 2018. Disponível em: <http://sbnbio.org.br>. Acesso em: 19 fev.2020.

SILVA, G. S; COSTA, P. A. A utilização de materiais alternativos para ensinar vírus: uma proposta de ensino para professores de ciências do Ensino Fundamental. Trabalho de conclusão de curso (graduação em ciências naturais- biologia). Universidade do Estado do Pará. Cametá, 2013. 
doi $10.48209 / 978-65-89949-14-8$

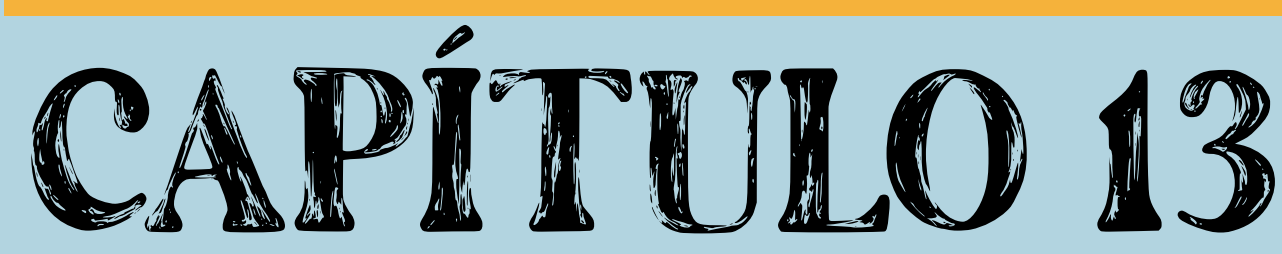

ENSINO DE CIÊNCIAS: APRESENTAÇÃO DE UMA PROPOSTA DE TRILHA DE APRENDIZAGEM PARA 0 ENSINO DE CONTEÚDOS DE ASTRONÁUTICA NO $5^{\circ}$ ANO DO ENSINO FUNDAMENTAL

Claudia de Oliveira Lozada 


\section{INTRODUÇÃo}

As missões espaciais sempre exerceram fascínio no público em geral, pois a conquista de outros planetas e a exploração de seus satélites naturais traz uma perspectiva de colonização pelo ser humano de outros lugares além do planeta Terra. Deste modo, os esforços humanos ao longo de décadas para desenvolver tecnologia que pudesse concretizar o desejo de conquista levaram o Homem à Lua em 1969 e mais recentemente, em 2021, missões norte-americana e chinesa não tripuladas pousaram no solo de Marte.

Ao longo desse tempo, a hegemonia das agências espaciais na exploração espacial foi dando lugar às empresas que investiram milhões para o desenvolvimento de tecnologia para missões tripuladas e não tripuladas com o aumento do número de testes, de modo que oferecessem menos riscos de acidentes e se tornassem mais ágeis no envio de carga para a Estação Espacial Internacional.

Por outro lado, tanto as agências espaciais como as empresas do setor aeroespacial criaram programas educativos para a disseminação da cultura espacial entre o público escolar e também entre o público em geral, elaborando material didático que pode ser utilizado nas aulas de Ciências e que tem como enfoque principal, o STEM (que significa Ciência, Tecnologia, Engenharia e Matemática), promovendo também a cultura maker e a inserção de TDICs (Tecnologias Digitais de Informação e Comunicação) no ensino de conteúdos de Astronáutica.

No entanto, os conteúdos de Astronáutica ainda não integram o currículo de Ciências e nem de Física da Educação Básica no Brasil e alguns tópicos são abordados pontualmente pelos livros didáticos na parte de experimentação, textos complementares ou em boxes de curiosidades. Porém, os alunos da Educação Básica têm interesse pela temática de Astronáutica e em competições científicas como a Mostra Brasileira de Foguetes (MOBFOG) há uma grande participação de alunos. É importante colocar que o ensino de Astronáutica e Aeronáutica na Educação Básica no Brasil ainda não é um campo de investigação, portanto, não há ainda literatura a respeito, sendo os trabalhos realizados por Lozada et al (2020), Lozada et al (2019) e Celestino et al (2017) pioneiros. 
Assim, este trabalho apresenta os resultados de uma pesquisa qualitativa sobre o ensino de Astronáutica e Aeronáutica que teve como um de seus objetivos o desenvolvimento/adaptação de material didático para a inserção de conteúdos de Aeronáutica e Astronáutica na Educação Básica. Nesse sentido, trazemos um recorte da pesquisa, apresentando uma proposta de Trilha de Aprendizagem para o ensino de Astronáutica no $5^{\circ}$ ano do Ensino Fundamental. Para tanto, analisamos os aspectos conceitual, procedimental e atitudinal para construir os pilares da Trilha, considerando a utilização das tecnologias digitais de informação e comunicação, as atividades experimentais e motoras.

Pretende-se com esta proposta de trilha de aprendizagem contribuir para a inserção de conteúdos de Astronáutica na Educação Básica de modo transversal no componente curricular Ciências na unidade temática "Terra e Universo" estabelecendo correlação com os conteúdos previstos na Base Nacional Comum Curricular. Adotando o enfoque STEAM (Ciência, Tecnologia, Engenharia, Artes e Matemática) primamos pela alfabetização científica e tecnológica e atividades com viés de exploração para desenvolver as competências e habilidades, considerando-se a perspectiva hands on, na qual os alunos podem construir os experimentos para a sua aprendizagem. A trilha pode ser aplicada tanto em ensino remoto quanto em ensino presencial. O ensino remoto ganhou notoriedade em 2020 com a suspensão das aulas presenciais em virtude da pandemia do Covid 19 , ocorrendo de modo virtual por meio de aulas síncronas e assíncronas. Desta forma, trazemos um material didático potencialmente significativo adaptando os materiais disponíveis pela Agência Espacial NASA para que o professor possa trabalhar conteúdos de Astronáutica no $5^{\circ}$ ano do Ensino Fundamental.

\section{AS ATIVIDADES EXPLORATÓRIAS PARA O ENSINO DE CIÊNCIAS: O MODELO SCIS PARA O ENSINO DE ASTRONAÚTICA}

Os estudos em ensino de Ciências têm trabalhado com a perspectiva do ensino por investigação. Como referencial teórico desta pesquisa, adotamos as concepções do ensino exploratório enunciadas pelo Science Curriculum Improvement Study (SCIS) situando-as no contexto do Ensino de Ciências, tendo em vista que deseja-se com a trilha de aprendizagem proposta a inserção de conteúdos de Astronáutica no $5^{\circ}$ ano do Ensino Fundamental, de modo que os alunos estabeleçam um contato inicial que os permita explorar os conceitos de maneira 
atrativa e lúdica, preparando-os para futuras atividades investigativas que lhes possibilitem percorrer outras etapas com problematização.

A estrutura da atividade de exploração aqui proposta como foi dito anteriormente foi inspirada num modelo denominado de Science Curriculum Improvement Study (SCIS), concepção norte-americana voltada para o currículo do ensino de Ciências.

A escolha por esse modelo deu-se pelo fato de que os conteúdos de Astronáutica não estão presentes no currículo de Ciências no Brasil e aparecem rarefeitos e pontuais nos livros didáticos como tópicos de seções de Curiosidades ou Leitura Complementar, havendo a necessidade de familiarizar os alunos com o contexto da Astronáutica. Assim, esse primeiro contato exige uma abordagem que permita mais exploração do conteúdo, no sentido de que os alunos vão realizando suas descobertas e se familiarizando com os conteúdos de Astronáutica.

O modelo SCIS surgiu na década de 60 no âmbito das reformas curriculares norte-americanas, conforme explica Fuller (2003). Concebido por Robert Karplus, o modelo baseava-se no tripé explorar, inventar e descobrir, e possui um caráter mais exploratório, ensejando um contato inicial do aluno com a Ciência desde a Educação Infantil, numa aproximação que Ihe convide a fazer Ciência. Karplus, seu idealizador, foi um físico teórico que migrou para a área de ensino de Ciências destacando-se na elaboração de currículo de Ciências para a Educação Básica.

Inspirado pelas concepções construtivistas de Piaget, seus estágios de desenvolvimento e a importância da criança aprender por meio de experiências e vivências nos diferentes contextos, na relação como os diferentes objetos e situações para construir os conceitos científicos, Karplus concebeu o modelo SCIS com suas fases e iniciou uma era de concepções curriculares que tivessem como ponto central etapas bem definidas para caracterização das práticas em ensino de Ciências. Por outro lado, cabe colocar que esse modelo foi concebido numa época em que Estados Unidos e a União Soviética (atual Rússia) disputavam a corrida espacial, sendo que em 1957 foi lançado o satélite soviético Sputnik, abrindo caminhos para que os governos se preocupassem com a formação de futuros cientistas e engenheiros (PORTAL G1, 2019). 
Retornando ao modelo SCIS, este se baseia em três fases (HOOVER, 1976): a primeira consiste em exploração em um ambiente orientado para a atividade proposta pelo professor, permitindo que os alunos explorem os materiais que são destinados à aprendizagem; a segunda fase denominada de invenção conduz os alunos em direção aos conceitos, reunindo suas observações e usando-as para que tenham como se organizar cognitivamente e compreender suas experiências e a terceira fase chamada de descoberta/aplicação, em que os alunos irão descobrir relações e ampliar suas experiências, tendo a oportunidade de usar os conceitos recém-formados em novos contextos. O modelo SCIS envolve oito processos científicos básicos: observação, comparação, classificação, quantificação, medição, experimentação, inferência e previsão, que estão ligados ao desenvolvimento de habilidades.

No modelo SCIS, o aluno é colocado como o centro do processo ensino-aprendizagem e o papel do professor é de ouvir os alunos e acompanhar como estão progredindo em suas investigações, conduzindo os alunos para que percebam as relações das descobertas que fazem com os conceitos científicos no sentido de formalizá-los considerando a linguagem científica, e desta forma, atingindo a alfabetização cientifica. Para utilização do SCIS, os professores recebiam treinamento para aplicar o modelo e utilizar o material didático dos kits.

Na época em que foi concebido, o modelo SCIS trazia kits modulares com as atividades a serem realizadas em sala de aula, para proporcionar experiências diretas e concretas para os alunos em Ciências. Fishleder (1972) coloca que a utilização dos kits constitui uma estratégia de ensino para que os alunos explorem materiais científicos selecionados, que os incentivem a explorar, investigar, discutir o que observam e perguntar. Um estudo realizado por Hoover (1976) para sua tese de Doutorado defendida em 1976 demonstrou que alunos em todos os anos escolares responderam com atenção, interesse e entusiasmo para grande parte do material experimental dos kits do SCIS, sendo que os relatórios de professores e observadores confirmaram as expectativas dos autores do material de que os alunos seriam fortemente motivados no estudo de Ciências e considerariam a combinação de experiência e descoberta um desafio estimulante.

Adaptando para o contexto atual, podemos reunir as atividades em sequências didáticas ou em trilhas de aprendizagem que podem ser utilizadas em ensino presencial ou remoto, valorizando a utilização de material de baixo custo e acessível aos alunos. Passemos à descrição da trilha de aprendizagem. 


\section{A PROPOSTA DE TRILHA DE APRENDIZAGEM PARA O ENSINO DE CONTEÚdOS DE ASTRONÁUTICA NO $5^{\circ}$ ANO DO ENSINO FUNDAMENTAL}

Para elaboração da trilha de aprendizagem consideramos três tipos de conteúdos estudados por Zabala (1998) para compor as dimensões de abordagem do material didático, partindo de uma concepção de atividade exploratória considerando o modelo SCIS e adaptando-o ao contexto do ensino de Ciências brasileiro. Desta forma, a abordagem da trilha de aprendizagem considerou os aspectos conceitual (quais conteúdos de Astronáutica foram selecionados), procedimental (quais procedimentos os alunos utilizariam para resolver a atividade proposta na trilha de aprendizagem) e atitudinal (as aplicações no cotidiano dos alunos e a tomada de decisão dos mesmos diante do uso dos conceitos em diversos contextos). A Trilha de Aprendizagem é destinada aos alunos do $5^{\circ}$ ano do Ensino Fundamental, sendo desenvolvida por meio de projeto, de modo transversal, com enfoque STEAM. A unidade temática do componente curricular Ciências na qual deverá ser inserida é "Terra e Universo" em virtude dos conteúdos de Astronáutica se correlacionarem com os conteúdos desta unidade temática.

Esta trilha de aprendizagem também pode ser utilizada em aulas remotas de Ciências, pois as atividades são facilmente executadas e com material acessível, podem ser enviadas para que as alunos imprimam, resolvam e apresentam nas aulas síncronas, assim como os experimentos podem ser realizados com supervisão dos pais ou responsáveis, podendo ser gravados e colocados como atividades das aulas assíncronas e apresentados em seminários de aulas síncronas. Desde março de 2020 em virtude da pandemia causada pelo COVID 19, as aulas presenciais foram suspensas e são ministradas remotamente (MEC, 2020) e, em 2021, embora, em fevereiro muitos Estados tivessem programado o retorno das aulas presenciais, a segunda onda da pandemia fez com que as aulas fossem suspensas e as atividades remotas retomadas. Então, a trilha de aprendizagem que apresentamos neste trabalho é uma ótima opção para os professores abordarem conteúdos de Astronáutica. 
A seguir, apresentamos um quadro de referência com a descrição da Trilha de Aprendizagem:

\section{Quadro 1 - Organização da Trilha de Aprendizagem}

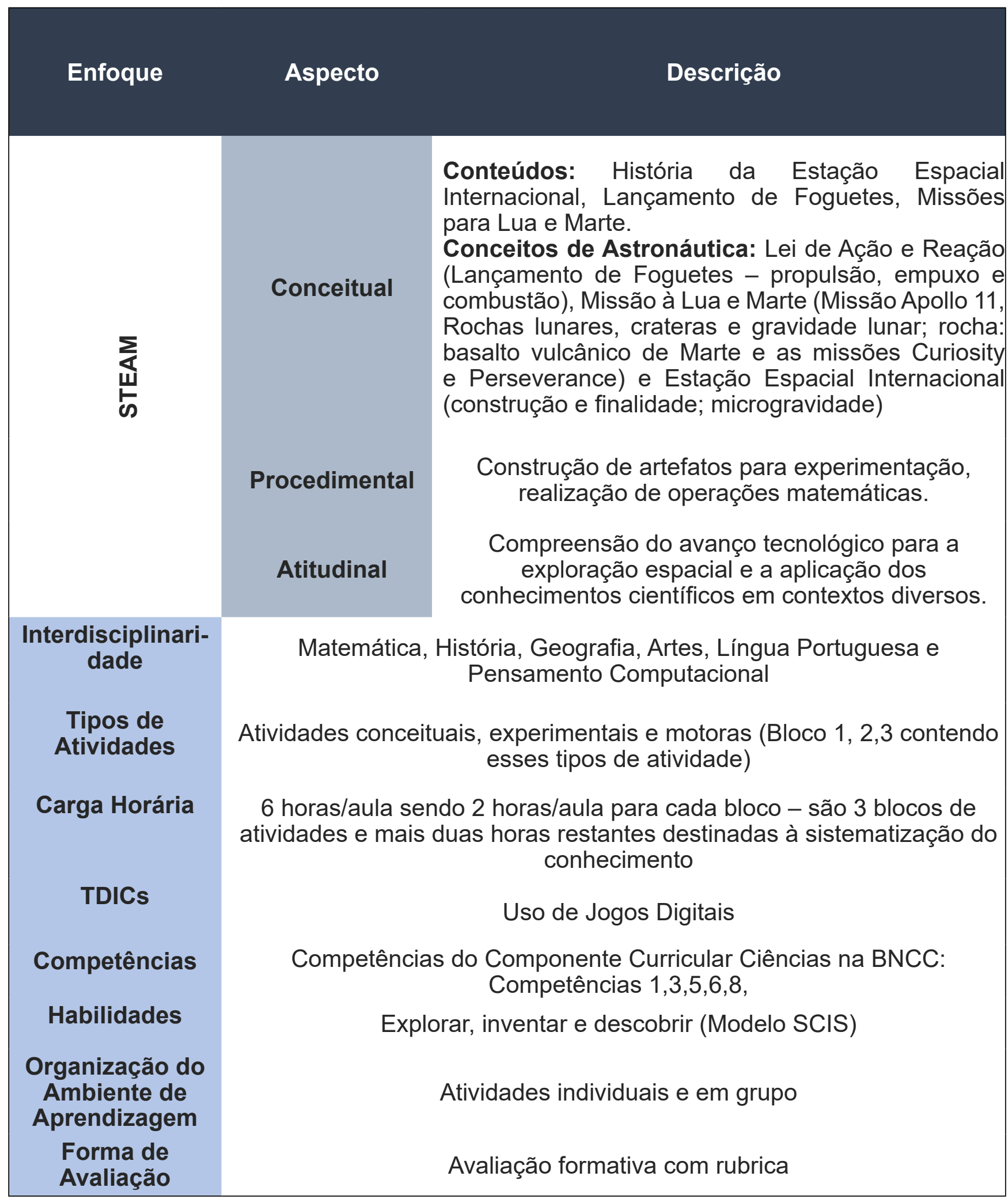

Fonte: Elaborado pela autora. 
A organização da Trilha de Aprendizagem foi concebida a partir da seleção e adaptação dos materiais da NASA (Agência Espacial Norte-Americana - vide nota de rodapé com os links dos materiais), tendo em vista que a NASA possui um programa STEAM estruturado e com atividades divididas por faixa etária. O material foi distribuído considerando atividades motoras (de manipulação e montagem - procedimental), atividades experimentais (de montagem - procedimental e atitudinal) e atividades teóricas (voltadas para os conceitos de Astronáutica - conceitual e atitudinal).

Sugerimos a aplicação da proposta com tempo estimado de 6 horas/aula, considerando 2 horas/aula para cada um dos 3 blocos de atividades, com atividades individuais e em grupo e acompanhamento do processo de aprendizagem por meio de rubrica.

O Bloco 1 de Atividades contempla as atividades conceituais que tem como foco principal o aspecto conceitual e a competência a ser desenvolvida é a Competência 1: "Compreender as Ciências da Natureza como empreendimento humano, e o conhecimento científico como provisório, cultural e histórico (BRASIL, 2018, p. 324)".

A interdisciplinaridade é realizada com os componentes curriculares Matemática, Língua Portuguesa e História. O professor deverá apresentar a Estação Espacial Internacional (ISS) para os alunos, sua história, extensão, como foi construída e qual a sua finalidade. Como material de apoio, o professor poderá acessar os links da NASA, que possui material sobre a ISS e um vídeo que conta a história dos 20 anos da ISS ${ }^{1}$. Poderá também buscar outros materiais complementares em outras fontes para agregar à aula teórica. As atividades podem ser realizadas individualmente. A seguir, apresentamos as atividades:

\section{Atividade 1 - Aniversário da Estação Espacial Internacional}

O professor deverá distribuir a folha com os cards para os alunos resolverem o desafio. Enunciado da Atividade: Em 2 de novembro, a NASA comemora o aniversário da Estação Espacial Internacional. Resolva os quebra-cabeças abaixo para aprender fatos sobre a órbita!

1 Os links com os referidos materiais são estes: https://www.nasa.gov/mission_pages/ station/overview/index.html, https://www.nasa.gov/station20 
Figura 1 - Cards da atividade 1

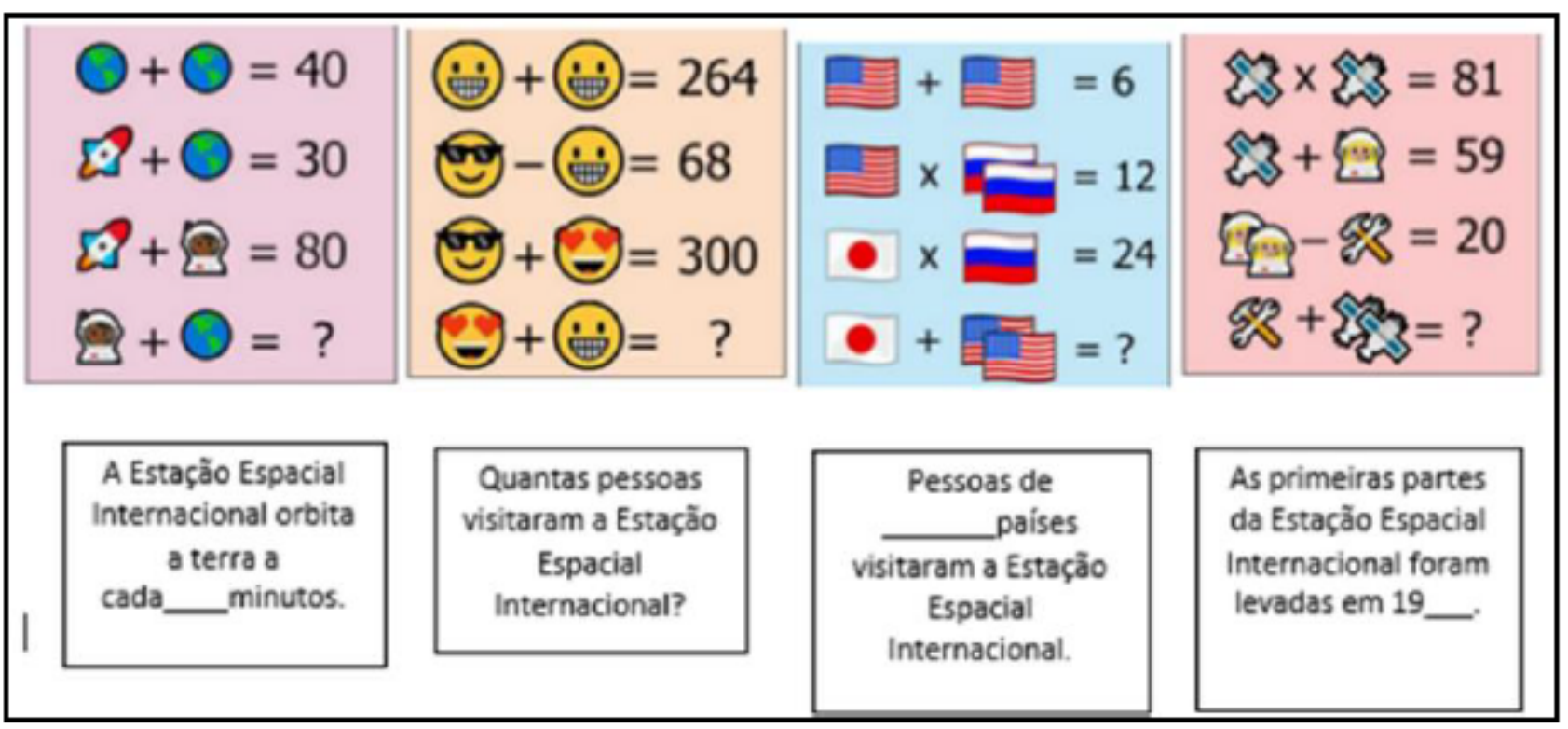

Fonte: Adaptado pela autora (2021)

\section{Atividade 2 - Quanto você sabe sobre a Estação Espacial Internacional?}

O professor deve distribuir a folha com a atividade para os alunos resolverem o desafio. ${ }^{1}$

Enunciado da Atividade: Leia as afirmações e preencha a cruzadinha.

Figura 2 - Atividade 2

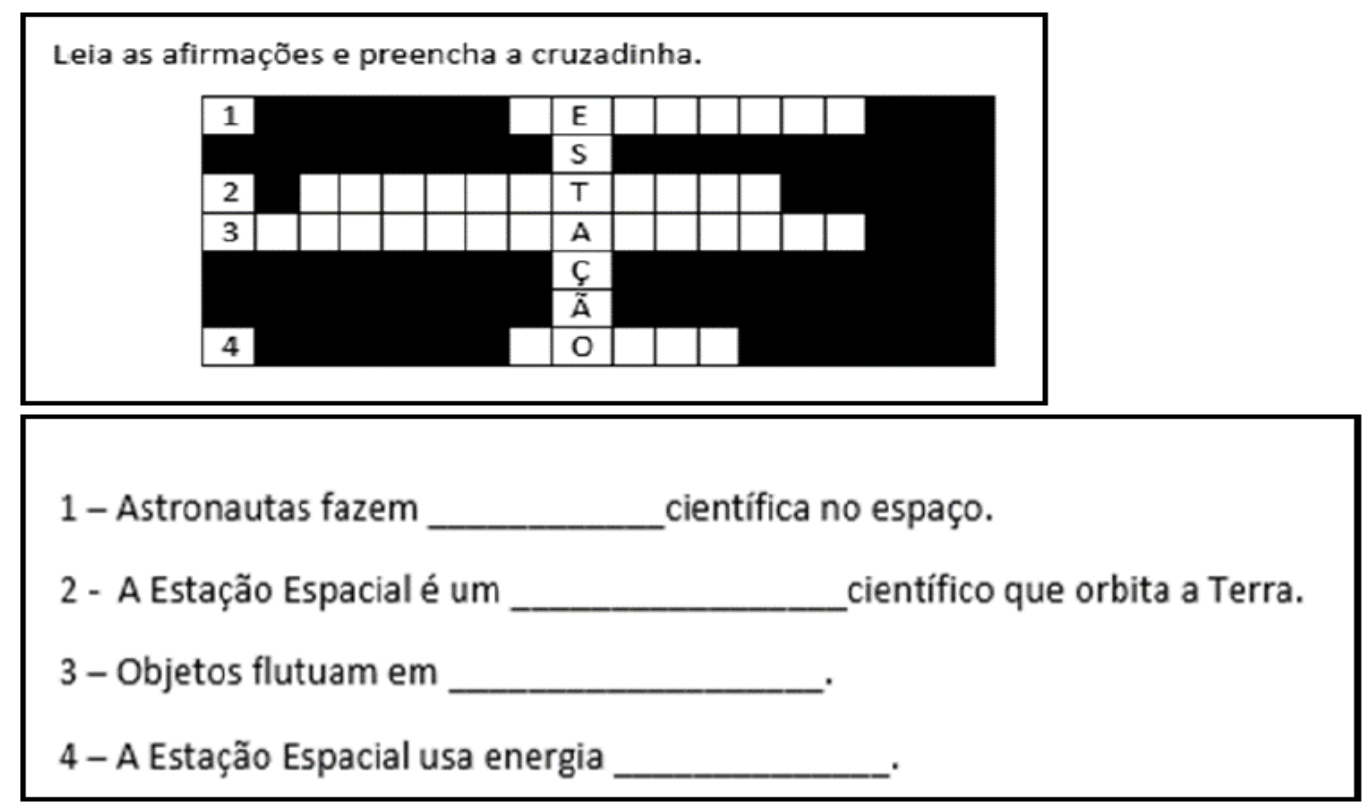

Fonte: Adaptado pela autora (2021)

$1 \quad$ Atividade adaptada: a atividade foi traduzida e, portanto, algumas palavras na tradução não se encaixaram na cruzadinha e ficaram apenas quatro palavras. 
O Bloco 2 contempla atividades conceituais, experimentais e motoras. Os aspectos enfatizados são estes: Conceitual (conteúdo teórico), Procedimental (montagem de um foguete e de um módulo de pouso) e Atitudinal (reflexões sobre as implicações dos impactos do avanço tecnológico na sociedade). A interdisciplinaridade é realizada com os componentes curriculares História e Artes. As competências a serem desenvolvidas são as seguintes:

1. Compreender as Ciências da Natureza como empreendimento humano, e o conhecimento científico como provisório, cultural e histórico.

2. Compreender conceitos fundamentais e estruturas explicativas das Ciências da Natureza, bem como dominar processos, práticas e procedimentos da investigação científica, de modo a sentir segurança no debate de questões científicas, tecnológicas, socioambientais e do mundo do trabalho, continuar aprendendo e colaborar para a construção de uma sociedade justa, democrática e inclusiva.

3. Analisar, compreender e explicar características, fenômenos e processos relativos ao mundo natural, social e tecnológico (incluindo o digital), como também as relações que se estabelecem entre eles, exercitando a curiosidade para fazer perguntas, buscar respostas e criar soluções (inclusive tecnológicas) com base nos conhecimentos das Ciências da Natureza.

8. Agir pessoal e coletivamente com respeito, autonomia, responsabilidade, flexibilidade, resiliência e determinação, recorrendo aos conhecimentos das Ciências da Natureza para tomar decisões frente a questões científico-tecnológicas e socioambientais e a respeito da saúde individual e coletiva, com base em princípios éticos, democráticos, sustentáveis e solidários. (BRASIL, 2018, p. 324)

O professor deverá apresentar a história dos foguetes, como são lançados e a importância deles para a exploração espacial, sobretudo, com a chegada do Homem na Lua. Como material de apoio, o professor poderá acessar os links da NASA, que possui material sobre foguetes ${ }^{1}$. Como material de apoio poderá selecionar vídeos e textos complementares. As atividades a seguir podem ser feitas em grupo ou individual; caso sejam em grupo, sugerimos duplas ou trios.

1 O link da Nasa é este: https://spaceplace.nasa.gov/launching-into-space 


\section{Atividade 1: Como montar um foguete com papel e canudo}

O material é papel, fita adesiva, lã e canudo. Desenhe um foguete no papel e recorte, cole a lã vermelha na ponta do foguete:

Figura 3 - Construção do Foguete de Papel

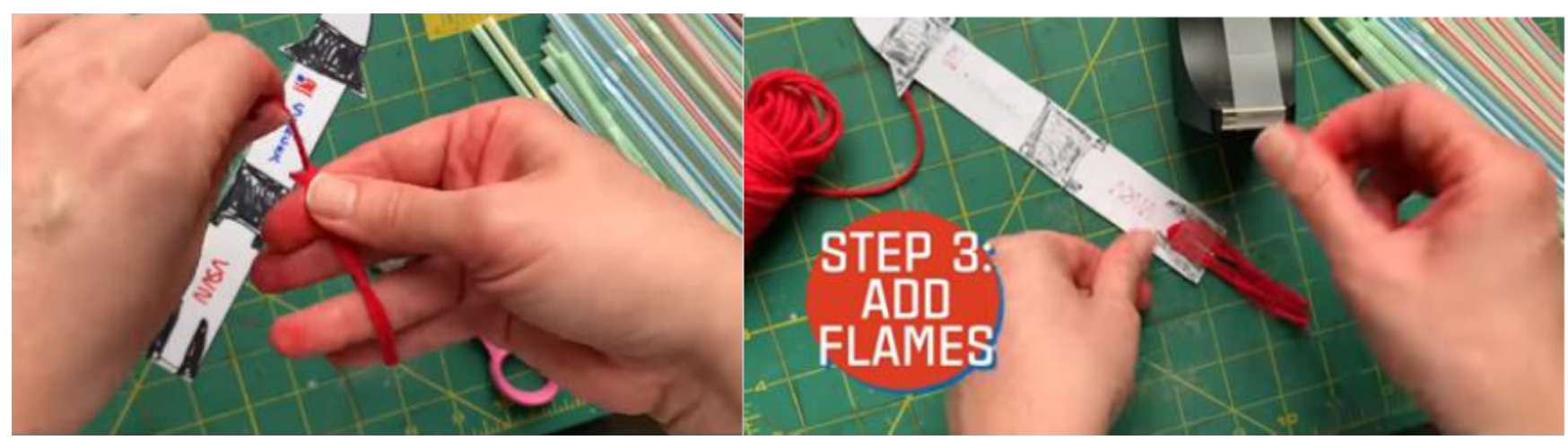

Fonte: Nasa (2021)

Dobre um pedaço de papel, de modo que fique denso e sirva de apoio ao foguete, colando-o no verso do foguete. Em seguida, encaixe o canudo, e para lançar o foguete, é só assoprar o canudo.

Figura 4 - Finalização da construção do Foguete de Papel

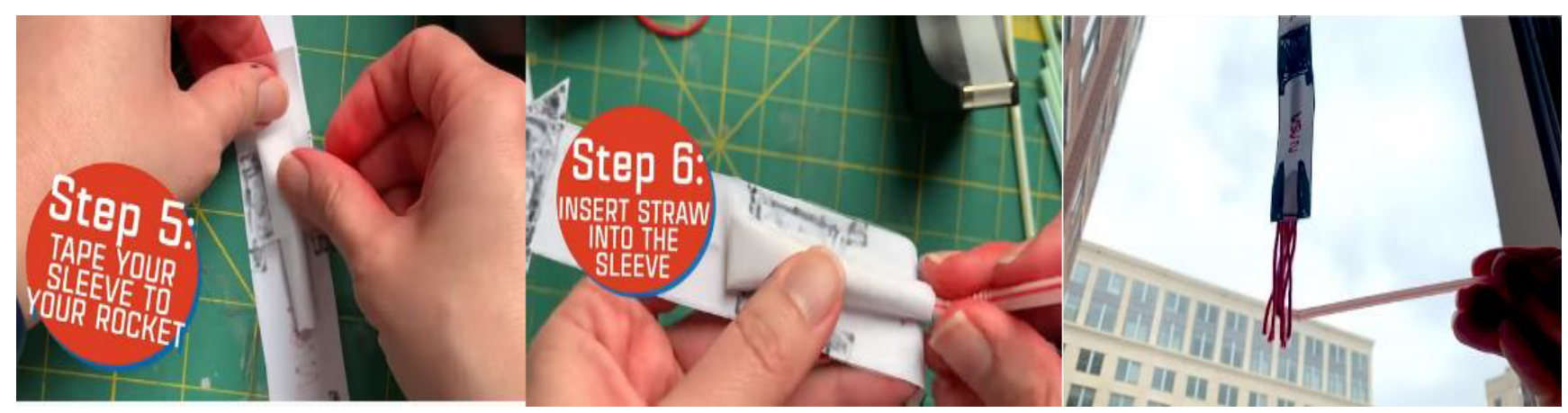

Fonte: Nasa (2021)

Esta atividade é feita com material acessível e não traz riscos para os alunos, pois há outros modelos de foguete que envolvem água e misturas como bicarbonato de sódio e vinagre como "combustíveis" para o lançamento e que podem causar riscos, devendo sua construção ser supervisionada pelos professores. Como são crianças do $5^{\circ}$ ano do Ensino Fundamental, este modelo de foguete é fácil de montar e também pode ser utilizado em aulas remotas de Ciências, sendo uma atividade lúdica cuja construção e execução pode ser acompanhada pelos pais ou responsáveis. 


\section{Atividade 2: A conquista da Lua (Atividade Motora)}

Com a utilização do molde a seguir, os alunos recortarão e montarão um módulo de pouso e uma Lua 3D, abordando as características da Lua, satélite natural da Terra e a chegada do Homem com a Missão Apollo 11, há meia década atrás -53 anos atrás.

Figura 5 - Montagem da conquista da Lua
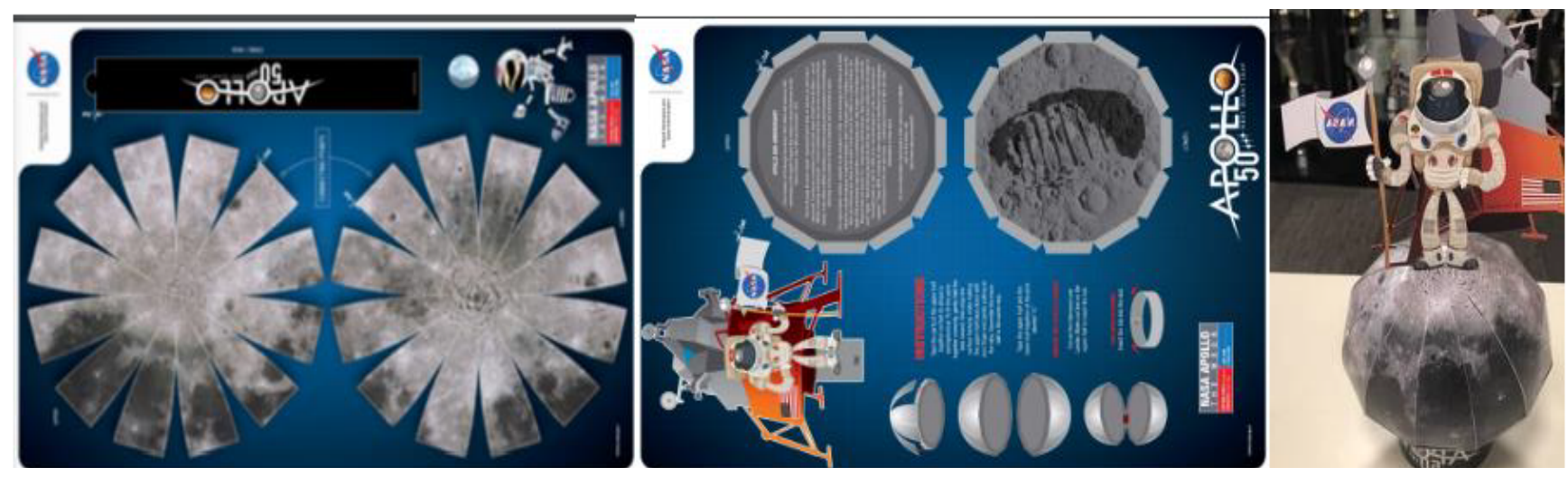

Fonte: Nasa (2021)

O Bloco 3 tem como foco as atividades conceituais e motoras. Os aspectos ressaltados são: Conceitual (Marte e suas características, Missões à Marte), Procedimental (Execução de Jogo Digital e atividade para colorir com desenvolvimento motor) e Atitudinal (Reflexões sobre as implicações dos impactos do avanço tecnológico na sociedade). A interdisciplinaridade é realizada com História, Geografia, Artes e Pensamento Computacional. As competências a serem desenvolvidas são as seguintes:

1. Compreender as Ciências da Natureza como empreendimento humano, e o conhecimento científico como provisório, cultural e histórico.

3. Analisar, compreender e explicar características, fenômenos e processos relativos ao mundo natural, social e tecnológico (incluindo o digital), como também as relações que se estabelecem entre eles, exercitando a curiosidade para fazer perguntas, buscar respostas e criar soluções (inclusive tecnológicas) com base nos conhecimentos das Ciências da Natureza.

5. Construir argumentos com base em dados, evidências e informações confiáveis e negociar e defender ideias e pontos de vista que promovam a consciência 
socioambiental e o respeito a si próprio e ao outro, acolhendo e valorizando a diversidade de indivíduos e de grupos sociais, sem preconceitos de qualquer natureza.

6. Utilizar diferentes linguagens e tecnologias digitais de informação e comunicação para se comunicar, acessar e disseminar informações, produzir conhecimentos e resolver problemas das Ciências da Natureza de forma crítica, significativa, reflexiva e ética.

8. Agir pessoal e coletivamente com respeito, autonomia, responsabilidade, flexibilidade, resiliência e determinação, recorrendo aos conhecimentos das Ciências da Natureza para tomar decisões frente a questões científico-tecnológicas e socioambientais e a respeito da saúde individual e coletiva, com base em princípios éticos, democráticos, sustentáveis e solidários. (BRASIL, 2018, p. 324)

O professor deverá apresentar a história das missões espaciais e a importância delas para as descobertas sobre a vida em outros planetas, sobretudo, com a exploração de Marte. O professor deve abordar anteriormente sobre Marte e suas características e a NASA possui links com material didático. ${ }^{1}$ Neste último bloco, utilizamos TDICs por meio de um jogo digital.

\section{Atividade 1: Explorando Marte (Atividade Motora com uso de TDICs)}

\section{Jogo digital - Enunciado da Atividade: Você sempre quis viajar pela} superfície de outro planeta? Bem, você está com sorte! Em Explore Mars, você estará dirigindo um rover em Marte e coletando informações sobre as rochas marcianas. Primeiro, você escolherá uma rocha para investigar. Em seguida, você enviará uma sequência de comandos dizendo ao rover como chegar até a rocha. Não se esqueça de incluir o comando para analisar a rocha! Essa informação será enviada de volta para os cientistas na Terra. Você ganhará pontos toda vez que analisar com sucesso uma nova rocha marciana. Se você quer uma pontuação alta, planeje com cuidado. Algumas pedras valem muito mais pontos do que outras!

1 Os links relativos à Marte e suas missões são estes: https://spaceplace.nasa.gov/water-on-mars/en/, https://spaceplace.nasa.gov/all-about-mars/en/ 
Figura 6 - Jogo Digital Explore Mars

xplore Mars: A Mars Rover Game
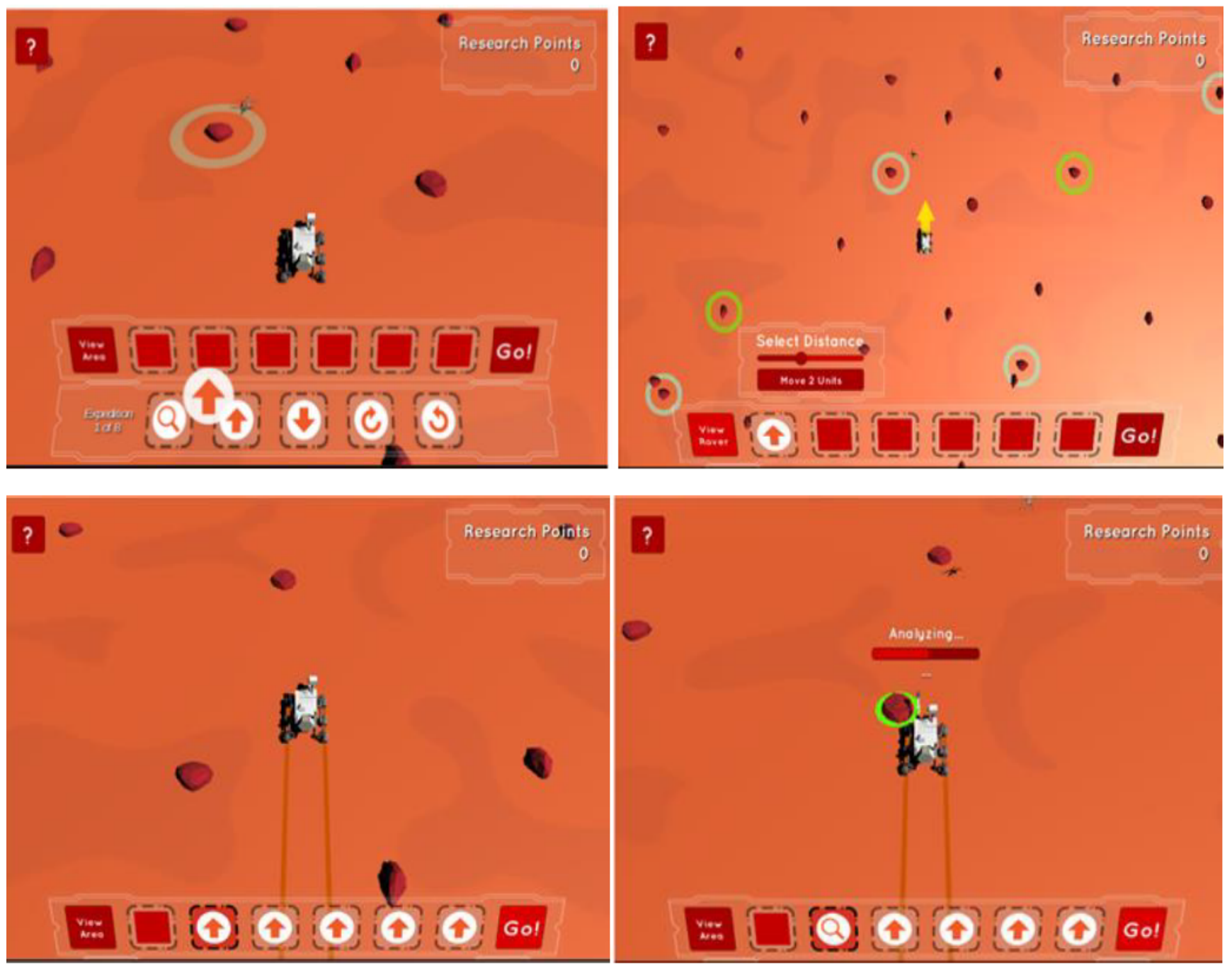

Fonte: Nasa (2021)

Atividade 2: Perserverance - Uma Missão para Marte (Atividade Motora)

O professor deverá abordar a Missão Perseverance e para tanto usará um material teórico bastante didático e objetivo ${ }^{1}$.A atividade consiste no professor explorar o conteúdo teórico das principais missões à Marte e, em seguida, distribuir atividades para colorir que trazem os veículos de exploração e o planeta Marte.

Enunciado da Atividade - Veículos para exploração de Marte: O rover Perseverance está procurando sinais de vida antiga em Marte, coletando rochas e amostras do solo que podem retornar à Terra um dia. Ele pesa aproximadamente 2.260 libras. Ele pousou em Marte, na cratera de Jezero, onde o delta do

1 O link é este: https://spaceplace.nasa.gov/mars-2020/en/ 
rio desaguava em um antigo lago há muito tempo. Possui 23 câmeras para navegar, estudar e fotografar o planeta vermelho. O professor deve distribuir as folhas para os alunos colorirem.

O helicóptero viajou para Marte junto com o rover Perseverance. Será o primeiro teste de um voo motorizado em outro planeta. É forte e leve. Pesa apenas 4 libras, mas é resistente o suficiente para sobreviver ao ambiente hostil em Marte. Ele pode voar sozinho, sem controle humano. O rover Curiosity tem o tamanho de um pequeno SUV. Possui 17 câmeras para navegar, estudar e fotografar o planeta vermelho. Ele descobriu que a água, como lagos e córregos - existiram em Marte por mais de um milhões de anos.

\section{Figura 7 - Atividade para colorir}
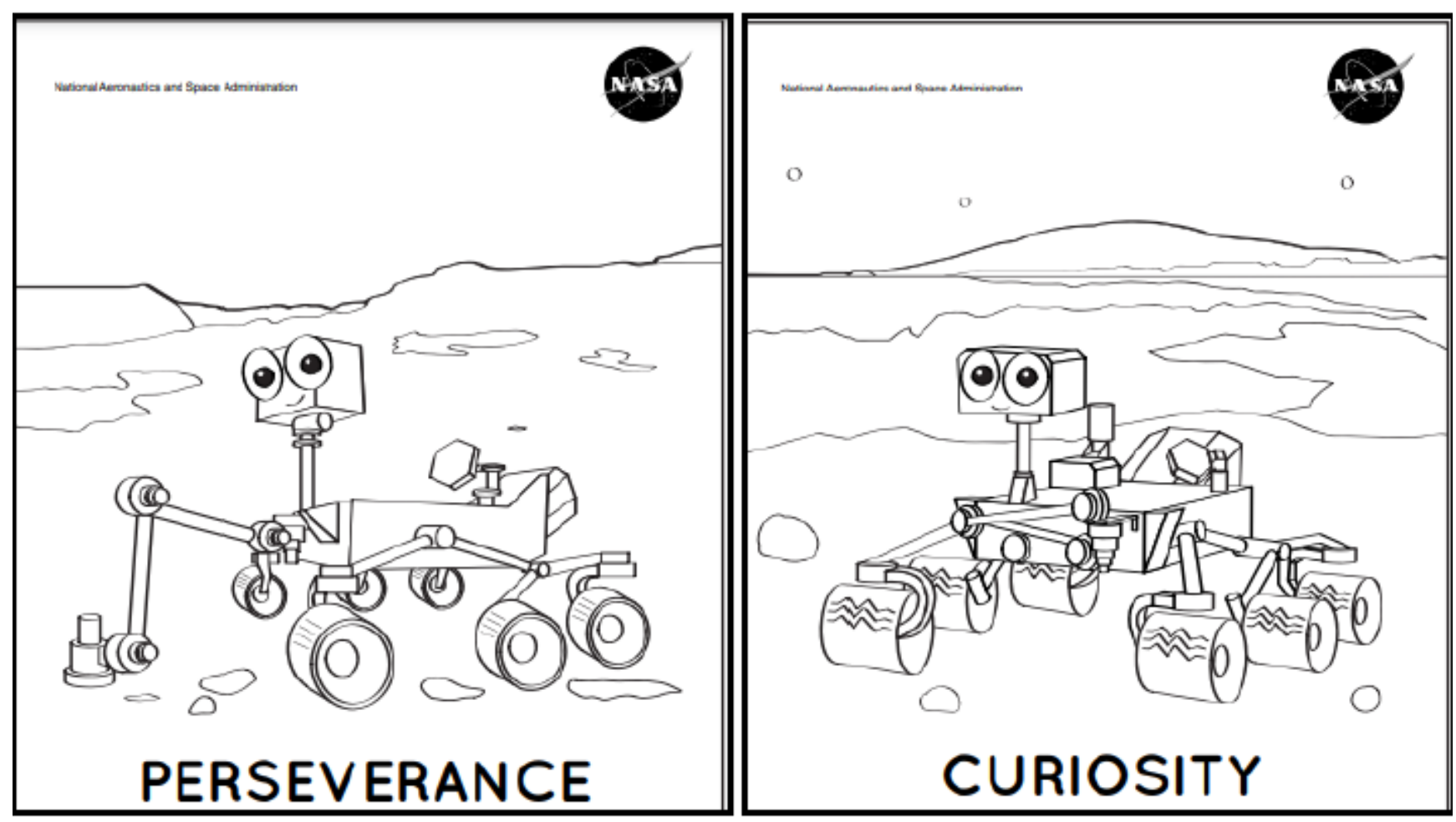

Fonte: Nasa (2021)

Marte: É um mundo frio e deserto. Tem clima e estações, assim como a Terra. Existem sinais de inundações antigas em Marte. O solo de Marte tem uma cor vermelha enferrujada, que vem do óxido de ferro em sua superfície. 
Figura 8 - Atividade para colorir

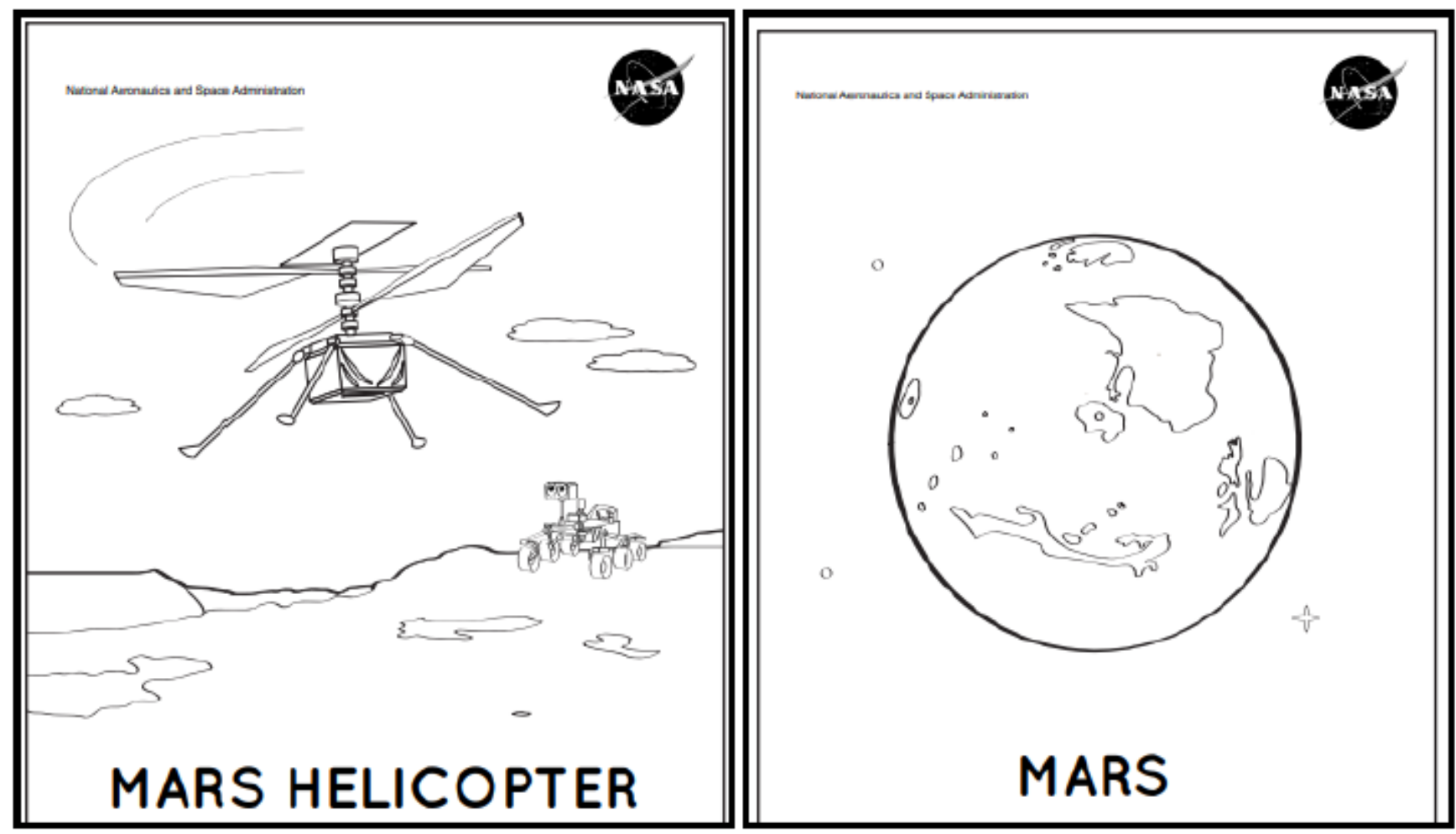

Fonte: Nasa (2021)

Em seguida, o professor deve passar vídeos que abordam o pouso de Perseverance em Marte e o pouso da espaçonave chinesa Tianwen-1 com rover chamado Zhurong e promover uma discussão sobre o tema, como vemos abaixo:

Figura 9 - Vídeos do You Tube sobre as missões que pousaram em Marte
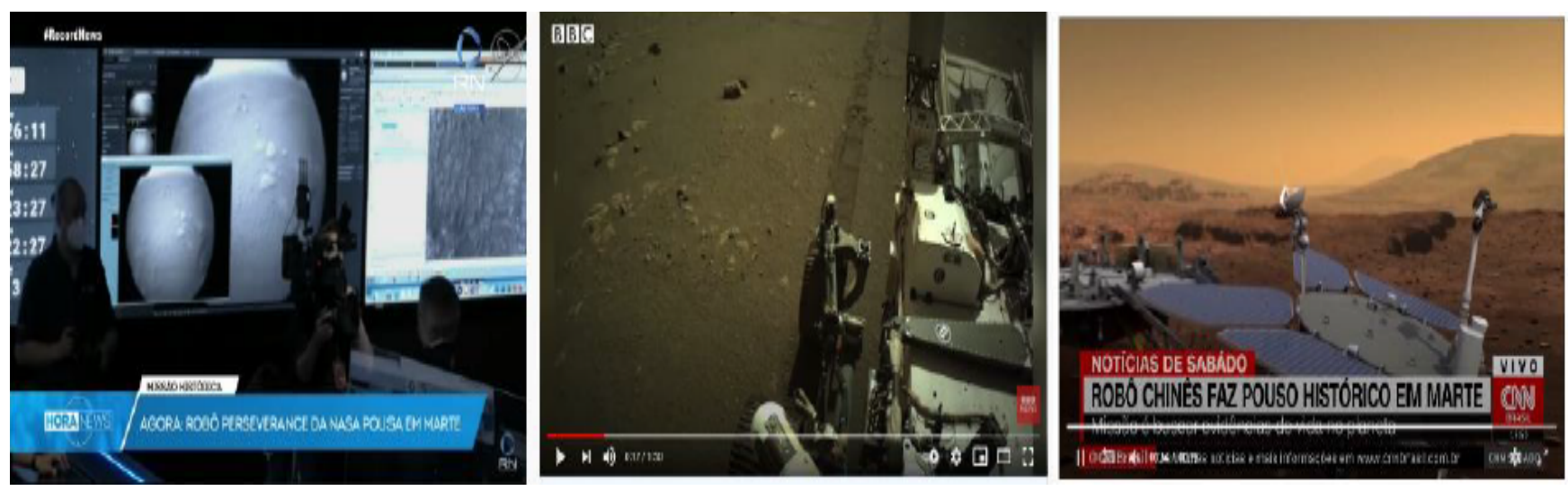

Fonte: YouTube (2021)

A seguir seguem os links de alguns vídeos sobre o pouso em Marte pelas missões norte-americana e chinesa: 
O ENSINO DE CIÊNCIAS NO BRASIL DURANTE E APÓS A PANDEMIA DA COVID-19: PERSPECTIVAS, DESAFIOS E POSSIBILIDADES

Quadro 2 - Vídeos do You Tube

\begin{tabular}{|c|c|}
\hline Título do Vídeo & Link no YouTube \\
\hline $\begin{array}{c}\text { Robô 'Perseverance' da Nasa } \\
\text { pousa em Marte }\end{array}$ & https://www.youtube.com/watch?v=w5LfbBLH-1w \\
\hline $\begin{array}{c}\text { Sonda da Nasa manda fotos } \\
\text { coloridas de Marte }\end{array}$ & https://www.youtube.com/watch?v=_XLylUKOCdQ \\
\hline $\begin{array}{c}\text { Perseverance: confira sons e } \\
\text { imagens de Marte captados } \\
\text { pela sonda }\end{array}$ & https://www.youtube.com/watch?v=rCVaUXjt28Q \\
\hline $\begin{array}{c}\text { Em feito histórico, nave da } \\
\text { China pousa em Marte }\end{array}$ & https://www.youtube.com/watch?v=D_TrAJyJO1U \\
\hline
\end{tabular}

Fonte: Elaborado pela autora (2021)

Após, a finalização dos blocos de atividades, é necessário que o professor promova um momento de sistematização do conhecimento para que revise o que foi abordado na trilha de aprendizagem e dê o fechamento do conteúdo.

\section{CONSIDERAÇÕES FINAIS}

A trilha de aprendizagem apresentada neste trabalho traz uma possibilidade de explorar novas temáticas no ensino de Ciências, com atividades que podem promover maior participação e engajamento dos alunos na medida que permitem desenvolver as dimensões conceitual e procedimental, além de propiciar aos alunos fazer Ciência por meio de experimentos. Abrange as três fases do SCIS: exploração, invenção e descoberta/aplicação, baseando-se no uso de materiais acessíveis que permitem a inserção das TDICs nas aulas por meio de um jogo interativo, possibilitando uma experiência com tema atual que é a chegada à Marte.

Além do mais, a abordagem da temática de Astronáutica proporciona uma atualização dos conteúdos, uma vez que é um tema atual e amplamente divulgado pelas mídias e provoca bastante curiosidade e interesse por parte dos alunos. É também um tema que perpassa pelas diferentes competências e habilidades previstas para o ensino de Ciências da Natureza, conforme a BNCC (BRASIL, 2018). Por fim, esperamos que essa proposta de atividade abra caminhos para a inserção de outros temas de Astronáutica no Ensino de Ciências da Educação Básica com enfoque STEAM. 


\section{REFERÊNCIAS}

BRASIL. Base Nacional Comum Curricular. Brasília: MEC/Secretaria de Educação Básica, 2018.

CELESTINO, C. C. et al. Projeto Arandu e a construção de satélites cansats no ensino médio. In: Encontro da Licenciatura em Física do IFUSP, 3., 2017, São Paulo. Anais... São Paulo: IFUSP, 2017.

FISHLEDER, J. The Science Curriculum Improvement Study. The american biology teacher. p. 389-391, 1972.

FULLER, R.G. “Don't tell me, l'll find out": Robert Karplus - a science education pioneer. Disponível em: https://digitalcommons.unl.edu/cgi/viewcontent. cgi?article=1021\&context=physicsfuller. Acesso em: 14 jul. 2021.

HOOVER, J. M. The effects of the Science Curriculum Improvement Study (SCIS) on svience achievement of selected sixth grade students. 1976. 143 f. Thesis. (Doctorade in Education) - Oregon State University, Corvallis, Oregon, 1976.

LOZADA, C. O. et al. Modelagem matemática aplicada ao ensino de física: o minifoguete. In: Encontro Regional de Matemática Aplicada e Computacional ERMAC, 6., 2019, Bauru - SP. Anais... Bauru - SP: SBMAC/UNESP, 2019.

O Projeto Astroem e o engajamento das jovens meninas nas ciências espaciais com enfoque STEM. In: Simpósio Brasileiro Mulheres em STEM, 2020, São José dos Campos. Anais...São José dos Campos: ITA, 2020.

MEC. Reorganização do Calendário Escolar e da possibilidade de cômputo de atividades não presenciais para fins de cumprimento da carga horária mínima anual, em razão da Pandemia da COVID-19. Disponível em: http://portal. mec.gov.br/index.php?option=com_docman\&view=download\&alias=145011pcp005-20\&category_slug=marco-2020-pdf\&ltemid=30192. Acesso em: 14 jul. 2021. 
PORTAL G1. Projeto Educação: entenda o contexto da corrida espacial e os reflexos na história moderna. Disponível em: https://g1.globo.com/pe/pernambuco/ educacao/noticia/2019/10/04/projeto-educacao-entenda-o-contexto-da-corridaespacial-e-os-reflexos-na-historia-moderna.ghtml. Acesso em: 14 jul. 2021.

ZABALA, A. A prática educativa: como ensinar. Porto Alegre: Artmed, 1998 


\section{SOBRE OS ORGANIZADORES}

\section{ALBERTO LOPO MONTALVÃO NETO}

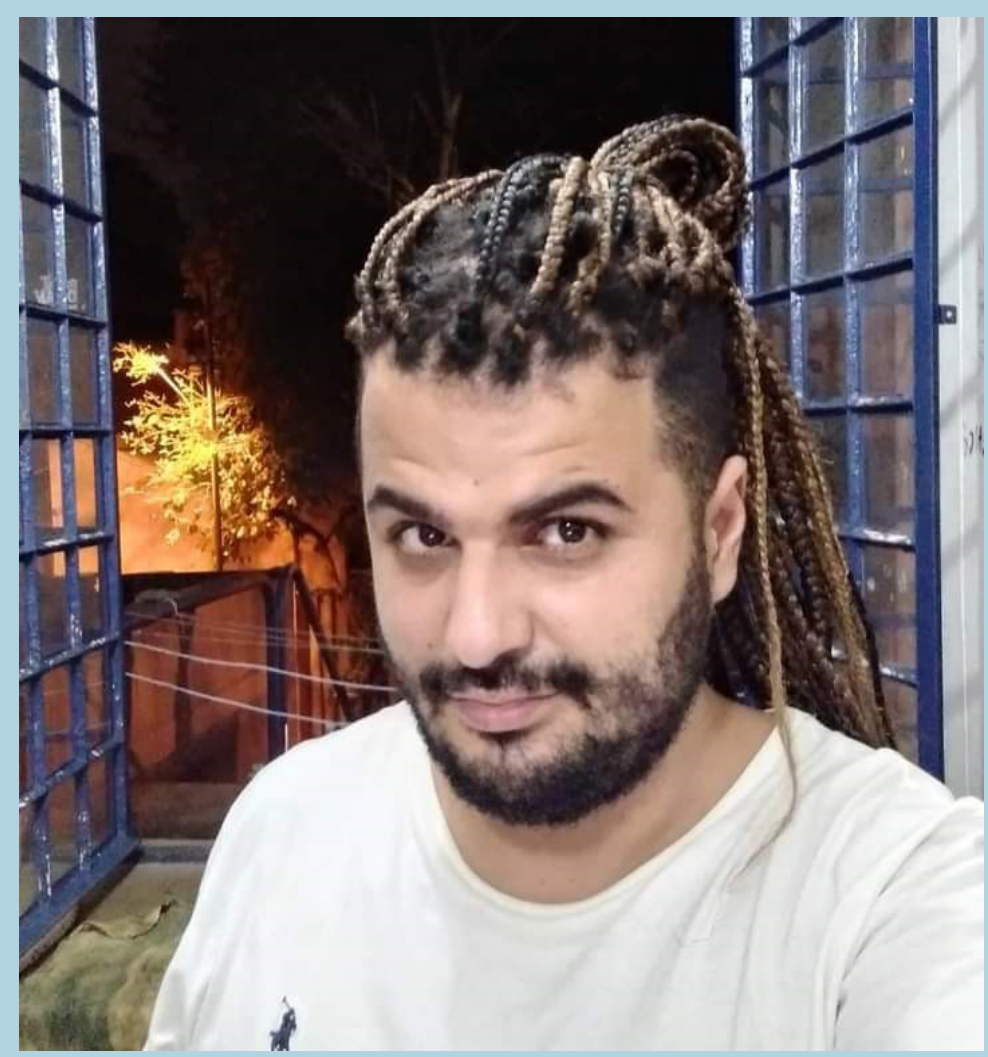

Doutorando em Educação pela Universidade Estadual de Campinas (UNICAMP). Mestre em Educação Científica e Tecnológica pela Universidade Federal de Santa Catarina (UFSC). Graduado em Licenciatura em Ciências Biológicas pela Universidade Federal de São Carlos (UFSCar Campus Sorocaba) e Universidade de Coimbra (Portugal). 


\section{FLÁVIA NOVAES MORAES}

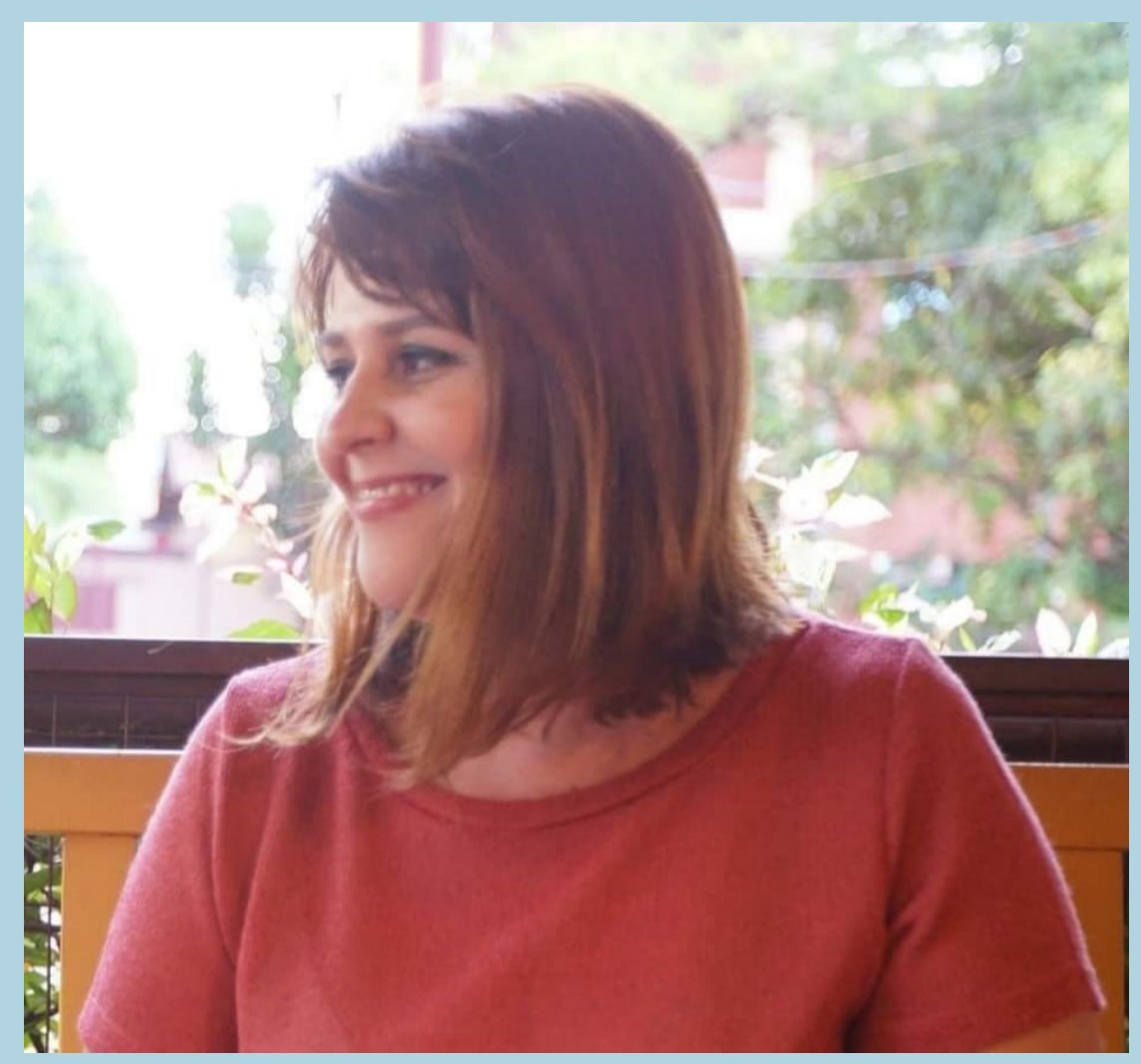

Doutoranda em Educação pela Universidade Estadual de Campinas (UNICAMP). Mestre em Biotecnologia pela Universidade de São Paulo (USP). Graduada em Ciências Biológicas pela Universidade Estadual Paulista Júlio de Mesquita Filho (UNESP) e em Licenciatura em Pedagogia pela Universidade Estadual de Campinas (UNICAMP). 


\section{WANDERSON RODRIGUES MORAIS}

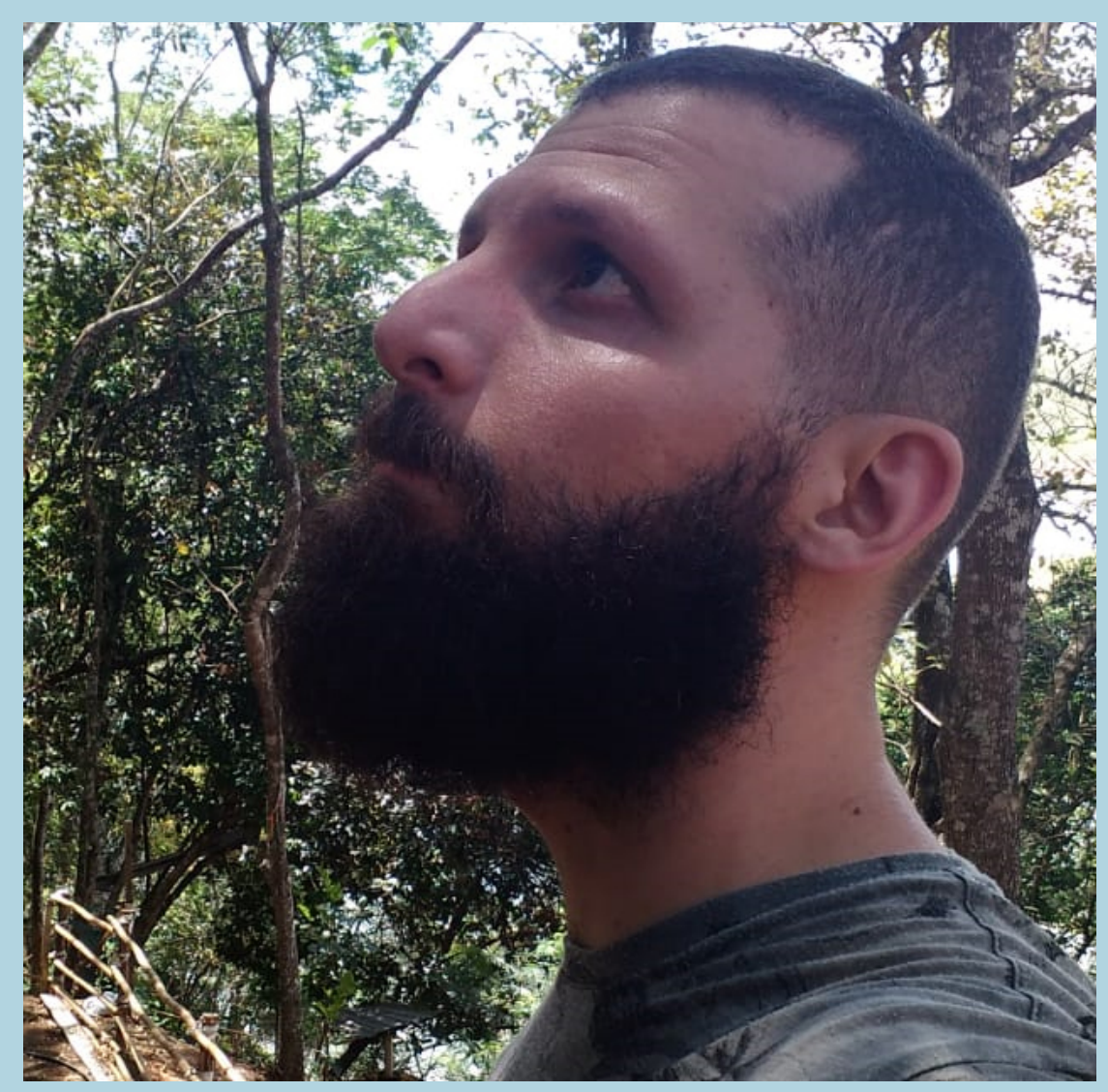

Doutor em Ensino de Ciências e Matemática pela Universidade Estadual de Campinas (UNICAMP); Mestre em Educação para a Ciência pela Universidade Estadual Paulista "Júlio de Mesquita Filho" (UNESP / Bauru); e Graduado em Licenciatura em Ciências Biológicas (UNESP / Ilha Solteira). 


\section{SOBRE AS AUTORAS E OS AUTORES}

\section{Amanda de Mattos Pereira Mano}

Professora da Universidade Federal de Mato Grosso do Sul, Câmpus do Pantanal, graduada em Ciências Biológicas pela Universidade Estadual de Mato Grosso do Sul (UEMS) e em Pedagogia pela Faculdade Centro Paulista (FACEP), Doutora e Mestra em Educação pela Universidade Paulista Júlio de Mesquita Filho - UNESP/Campus de Marília, e-mail: amanda.mano@ufms.br.

\section{Ana Flavia Zorzi}

Acadêmica do Curso de Licenciatura em Ciências Biológicas da Universidade Federal do Pampa, e-mail: anazorzi.aluno@unipampa.edu.br

\section{Alex Sandro Barros de Souza}

Doutorando em Ciência Animal (UFPR), Mestre em Entomologia (INPA), Bacharel e Licenciado em Ciências Biológicas (UFPEL) e professor EBTT no Instituto Federal do Paraná (IFPR). Umuarama, PR - Brasil.

e-mail: alex.desouza@ifpr.edu.br

\section{Alberto Lopo Montalvão Neto}

Doutorando em Educação pela Universidade Estadual de Campinas (UNICAMP). Mestre em Educação Científica e Tecnológica pela Universidade Federal de Santa Catarina (UFSC). Graduado em Licenciatura em Ciências Biológicas pela Universidade Federal de São Carlos (UFSCar - Campus Sorocaba) e Universidade de Coimbra (Portugal).

E-mail: montalvaoalberto@gmail.com.

\section{Allana Carla Garcia dos Santos}

Licenciada em Ciências Biológicas pelo Instituto Federal do Paraná (Umuarama). e-mail: allanacarla1605@gmail.com.

\section{Andre Santos Amorim}

Graduando em Ciências Biológicas, pela Universidade Federal do Espírito Santo, Campus São Mateus.

E-mail: andre.s.amorim@edu.ufes.br 


\section{Camila Carvalho Gomes}

Mestre em Ensino na Educação Básica pela Universidade Federal do Espírito Santo, Campus São Mateus.

E-mail: camillacgomes@yahoo.com.br

\section{Claudia de Oliveira Lozada}

Doutora em Educação pela Universidade de São Paulo (USP), Docente do Instituto de Matemática da Universidade Federal de Alagoas, Docente do Programa de Mestrado em Ensino de Ciências e Matemática (UFAL),

e-mail: cld.lozada@gmail.com.

\section{Érica Romão da Silva Lima}

Discente do curso de Licenciatura em Física no Instituto Federal do Piauí (IFPI) - Campus Picos.

e-mail: ericaromao1199@gmail.com

\section{Elaine Lima Silva}

Doutoranda no Programa de Pós-graduação em Ensino de Ciências e Matemática (UNICSUL), Mestra em Biodiversidade Vegetal e Meio Ambiente (IBt), Especialista no Ensino de Biologia (USP), MBA em Gestão Escolar EAD (USP-ESALQ), Licenciada em Ciências Biológicas (UNICASTELO), Química e Pedagogia (UNIMES). Docente do CEETEPS e da SEE de São Paulo.

e-mail: elimasilva39@gmail.com

\section{Flávia Novaes Moraes}

Doutoranda em Educação pela Universidade Estadual de Campinas (UNICAMP). Mestre em Biotecnologia pela Universidade de São Paulo (USP). Graduada em Ciências Biológicas pela Universidade Estadual Paulista Júlio de Mesquita Filho (UNESP) e em Licenciatura em Pedagogia pela Universidade Estadual de Campinas (UNICAMP).

E-mail: flaviamoraes@yahoo.com

\section{Flavio de Souza Júnyor}

Discente no curso de graduação em Medicina - Universidade Federal do Rio de Janeiro (UFRJ). Membro do Laboratório de Biologia das Células Gliais do Instituto de Ciências Biomédicas (ICB/UFRJ). E-mail: flavio.junyor@ufrj.br 


\section{Haroldo Reis Alves de Macêdo}

Doutor em Ciência e Engenharia dos materiais, pesquisador da área de Biomateriais, Professor do IFPI Campus Picos; formado em Licenciatura em Física; E-mail: haroldoram@igpi.edu.br

\section{Ivana Thariny de Lima Leal}

Graduada em Ciências Naturais - Habilitação em Biologia pela Universidade do Estado do Pará.

\section{Karina Carvalho Mancini}

Docente da Universidade Federal do Espírito Santo, Campus São Mateus. Bióloga graduada pela Universidade Estadual de Campinas e Doutora em Biologia Celular e Estrutural pela mesma instituição.

E-mail: karina.mancini@ufes.br

\section{Larissa Rodrigues Pereira}

Acadêmica do Curso de Licenciatura em Ciências Biológicas da Universidade Federal do Pampa.

E-mail:larissarp2.aluno@unipampa.edu.br

\section{Luiz Antonio Soares Cardoso}

Bacharel em Geologia pela Universidade Federal do Pará, Especialista em Segurança do Trabalho e Gestão Ambiental pela Faculdade Venda Nova do Imigrante e Mestreem Desenvolvimento Rural e Gestão de Empreendimentos Agroalimentares pelo Instituto Federal do Pará. Professor do Ensino Básico, Técnico e Tecnológico do IFPA. Doutorando no Programa de Pós-graduação em Agronomia pela Universidade Federal Rural da Amazônia.

\section{Lilia Cavicchioli Fonseca latecola}

Mestranda no programa de Mestrado Profissional em Ensino de Ciências e Matemática da Universidade Cruzeiro do Sul. Possui graduação em Fisioterapia pela Universidade de Marília (1997). Professora do Centro Universitário Nossa Senhora do Patrocínio.

E-mail: lilia.iatecola@ceunsp.edu.br 


\section{Mayra da Silva Cutruneo Ceschini}

Professora Substituta do Curso de Licenciatura em Ciências Biológicas da Universidade Federal do Pampa - Campus São Gabriel, Mestra em Ensino de Ciências, Doutoranda em Educação em Ciências: Química da Vida e Saúde pela Universidade Federal do Pampa - Campus Uruguaiana.

E-mail:mayraceschini@unipampa.edu.br

\section{Maria Inês de Affonseca Jardim}

Professora da Universidade Federal do Mato Grosso do Sul/ Cidade Universitária, graduada em Física pela Universidade Estadual de Londrina; Mestre em Educação pela Universidade Católica Dom Bosco; Doutora em Educação pela UFMS.

E-mail: maria.jardim@ufms.br.

\section{Marcelo Alberto Elias}

Doutorando em Ensino de Ciências e Matemática- PECIM (Unicamp), Mestre em Biologia das Interações Orgânicas (UEM), Especialista em Biotecnologia (UEM), Licenciado em Ciências Biológicas (UNINGÁ) e professor EBTT no Instituto Federal do Paraná (IFPR). Umuarama, PR - Brasil.

E-mail: marcelo.elias@ifpr.edu.br

\section{Margarida Maria Sandeski}

Mestre em Filosofia (UNIOESTE), Especialista em Ensino Superior (CEAP), Licenciada em Pedagogia (URI) e professora EBTT no Instituto Federal do Paraná (IFPR). Umuarama, PR - Brasil.

E-mail: margarida.sandeski@ifpr.edu.br

\section{Priscyla Cristinny Santiago da Luz}

Doutorado em Educação em Ciências e Matemática pela Universidade Federal de Mato Grosso, Mestrado em Educação em Ciências e Matemáticas pela Universidade Federal do Pará e graduação em Ciências Biológicas pela Universidade Federal do Pará.

E-mail: priscylaluz@gmail.com 


\section{Paula Montanhini Favetta}

Doutoranda e mestre em Ciência Animal com Ênfase em Produtos Bioativos da UNIPAR. Bolsista/CAPES/UNIPAR.

E-mail: nutripaulafavetta@gmail.com

\section{Rita de Cássia Frenedozo}

Bacharel em Ecologia e Ciências Biológicas pela Universidade Estadual Paulista Júlio de Mesquita Filho, mestrado em Ciências Biológicas (Biologia Vegetal) pela Universidade Estadual Paulista Júlio de Mesquita Filho e doutorado em Geociências e Meio Ambiente pela Universidade Estadual Paulista Júlio de Mesquita Filho. Atualmente é professora titular de Ciências Biológicas e da Saúde da Universidade Cruzeiro do Sul (São Paulo, SP). Orienta nos Programas de Mestrado/ Doutorado Acadêmicos em Ensino de Ciências e no Mestrado Profissionalizante em Ensino de Ciências e Matemática sob a temática ambiental.

E-mail: ritafrenedozo@yahoo.com.br

\section{Rosione Maria dos Santos Rodrigues}

Mestranda no Programa de Pós-graduação em Ensino de Ciências e Matemática (UNICSUL). Especialista em Gestão Ambiental para Educação (UNIMES), Educação em Libras (Faculdade de Educação São Luís). Graduada em Pedagogia (Centro Universitário Internacional). Licenciada em Letras com Ênfase em Libras (Faculdade Integrada de Ariquemes) e Biologia (CEUNSP). Docente e Intérprete de Libras SEE de São Paulo e Rede Privada.

E-mail: rosionemrodrigues01@gmail.com

\section{Ricardo de Melo Germano}

Possui graduação em Ciências Biológicas, especialização em Bases Morfológicas e Fisiológicas da Integração do Homem com o Meio, tem Mestrado e Doutorado em Biologia das Interações Orgânicas (Biologia Comparada) pela Universidade Estadual de Maringá. Professor Titular de Fisiologia da Universidade Paranaense- UNIPAR; também é Docente do Programa de Pós-graduação em Ciência Animal com Ênfase em Produtos Bioativos da UNIPAR (em nível de mestrado e doutorado).

E-mail: germano@prof.unipar.br 


\section{Renata Rúbia Ota}

Doutora em Ciências (PEA/UEM), Mestra em Ciências Ambientais (PEA/UEM), Licenciada em Ciências Biológicas (UEM) e professora substituta no Instituto Federal do Paraná (IFPR). Umuarama, PR - Brasil.

E-mail: renatarubia.ota@gmail.com

\section{Thomáz da Silva Guerreiro Botelho}

Professor das Escolas Neusa Assad Malta e Escola Estadual Leme do Prado, graduado em Ciências Biológicas pela Universidade Federal de Mato Grosso do Sul, Câmpus do Pantanal e Mestre pelo Programa de Pós Graduação em Biologia Vegetal da UFMS/ Cidade Universitária.

E-mail: guerreirobotelho@gmail.com.

\section{Tatiane Tenuta de Andrade}

Mestranda no Programa de Pós-graduação em Ensino de Ciências (UNICSUL), Especialista em Educação Ambiental (USP), Bacharel e Licenciada em Ciências Biológicas (USJT) e Pedagogia (UNIBAN). Docente do CEETEPS.

E-mail: tatiane.tenuta@gmail.com

\section{Tiago Maretti Gonçalves}

Graduado em Ciências Biológicas Licenciatura, pela Universidade Federal de Alfenas (UNIFAL); Mestre em Genética e Melhoramento pelo Programa de Pós-Graduação em Genética e Melhoramento da Universidade Estadual de Maringá (UEM); Doutor em Ciências pelo Programa de Pós-Graduação em Genética Evolutiva e Biologia Molecular da Universidade Federal de São Carlos (UFSCar). E-mail: tiagobio1@hotmail.com.

\section{Vera Maria Jarcovis Fernandes}

Doutora em Ensino de Ciências e Matemática (UNICSUL), Mestra em Ensino de Ciências e Matemática (UNICSUL). Graduada em Pedagogia pela (UNICSUL). Docente no curso de Licenciatura em Pedagogia Presencial no Grupo Educacional Cruzeiro do SUL, Coordenadora do Núcleo de Estágios da Cruzeiro do Sul (NUFEP) e Professora e Pesquisadora do Programa de Pós-graduação em Ensino de Ciências e Matemática - Universidade Cruzeiro do Sul. E-mail: vera.fernandes@cruzeirodosul.edu.br 


\section{Wanderson Rodrigues Morais}

Doutor em Ensino de Ciências e Matemática pela Universidade Estadual de Campinas (UNICAMP). Mestre em Educação para a Ciência pela Universidade Estadual Paulista Júlio de Mesquita Filho (UNESP). Graduado em Licenciatura em Ciências Biológicas pela UNESP.

E-mail:w.rmorais13@gmail.com.

\section{Wesley Alves Trindade}

Doutorando e mestre em Ciência Animal com Ênfase em Produtos Bioativos da UNIPAR. bolsista PROSUPE/CAPES/UNIPAR.

E-mail: wesleyalvest@gmail.com 
